DEPARTMENT OF THE INTERIOR

UNITED STATES GEOLOGICAL SURVEY

GEORGE OTIS SMITH, DIRECTOR

BULLetin 614

GUIDEBOOK

OF THE

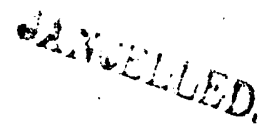

\title{
WESTERN UNITED STATES
}

\author{
PaRT D. THE SHASTA ROUTE AND \\ COAST LINE
}

BY

J. S. DILLER AND OTHERS

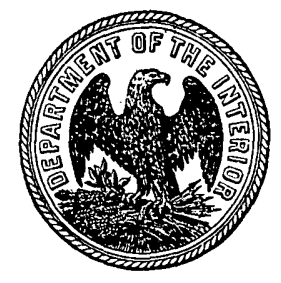

WASHINGTON

GOVERNMENT PRINTING OFFICE 


\section{Principal Divisions of Geologic Time.a}

[A glossary of geologic terms is given on pp. 133-136.]

\begin{tabular}{|c|c|c|c|c|}
\hline Era. & Period. & Epoch. & Characteristic life. & $\begin{array}{l}\text { Duration, accord. } \\
\text { ing to various } \\
\text { estimatcs. }\end{array}$ \\
\hline \multirow{2}{*}{$\begin{array}{l}\text { Cenozoic (re- } \\
\text { cent life). }\end{array}$} & Quaternary. & $\begin{array}{l}\text { Recent. } \\
\text { Pleistocene } \\
\text { (G r e a t } \\
\text { Ice Age). }\end{array}$ & $\begin{array}{l}\text { "Age of man." Animals and plants of } \\
\text { modern types. }\end{array}$ & \multirow[t]{2}{*}{$\begin{array}{l}\text { Millions of years. } \\
1 \text { to } 5 .\end{array}$} \\
\hline & Tertiary. & $\begin{array}{l}\text { Pliocenc. } \\
\text { Miocene. } \\
\text { Oligocene. } \\
\text { Eocene. }\end{array}$ & $\begin{array}{l}\text { "Age of mammals." Possible first appear- } \\
\text { ance of man. Rise and development of } \\
\text { highest orders of plants. }\end{array}$ & \\
\hline \multirow{3}{*}{$\begin{array}{l}\text { Mesozoic (in- } \\
\text { termediate } \\
\text { life). }\end{array}$} & Cretaceous. & $(b)$ & \multirow{3}{*}{$\begin{array}{l}\text { "Age of reptiles." Rise and culmination } \\
\text { of huge land reptiles (dinosaurs), of shell- } \\
\text { fish with complexly partitioncd coiled } \\
\text { shells (ammonites), and of great flying } \\
\text { reptiles. First appearance (in Jurassic) } \\
\text { of birds and mammals; of cycads, an } \\
\text { order of palmlike plants (in Triassic); } \\
\text { and of angiospermous plants, among } \\
\text { which are palms and hardwood trees } \\
\text { (in Cretaceous). }\end{array}$} & \multirow{3}{*}{4 to 10} \\
\hline & Jurassic. & (b) & & \\
\hline & Triassic. & (b) & & \\
\hline \multirow{7}{*}{$\begin{array}{l}\text { Paleozoic } \\
\text { (old life). }\end{array}$} & & Permian. & "Age of amphibians." Dominance of club & \multirow{8}{*}{17 to 25 . } \\
\hline & $\begin{array}{l}\text { Carbonifer- } \\
\text { ous. }\end{array}$ & $\begin{array}{l}\text { Pennsylva- } \\
\text { nian. }\end{array}$ & $\begin{array}{l}\text { and fern types. Primitive flowering } \\
\text { plants and earliest cone-bearing trees. } \\
\text { Beginnings of backboned land animals }\end{array}$ & \\
\hline & & $\begin{array}{l}\text { Missi s s i p- } \\
\text { pian. }\end{array}$ & $\begin{array}{l}\text { with nautilus-like coiled shells (ammon- } \\
\text { ites) and sharks abundant. }\end{array}$ & \\
\hline & Devonian. & $(b)$ & $\begin{array}{l}\text { "Age of fishes." Shellfish (mollusks) also } \\
\text { abundant. Rise of amphibians and land } \\
\text { plants. }\end{array}$ & \\
\hline & Silurian. & (b) & $\begin{array}{l}\text { Shell-forming sea animals dominant, espe- } \\
\text { cially those related to the nautilus (ceph- } \\
\text { alopods). Rise and culmination of the } \\
\text { marine animals sometimes known as sca } \\
\text { lilies (crinoids) and of giant scorpion- } \\
\text { like crustaceans (curypterids). Rise of } \\
\text { fishes and of reef-building corals. }\end{array}$ & \\
\hline & Ordovician. & (b) & $\begin{array}{l}\text { Shell-forming sea animals, especially ceph- } \\
\text { alopods and mollusk-like brachiopods, } \\
\text { abundant. Culmination of the bugliko } \\
\text { marine crustaceans known as trilobites. } \\
\text { First trace of insect life. }\end{array}$ & \\
\hline & Cambrian. & (b) & $\begin{array}{l}\text { Trilobites and brachiopods most charac- } \\
\text { teristic animals. Seaweeds (algæ) abun- } \\
\text { dant. No trace of land animals found. }\end{array}$ & \\
\hline \multirow{2}{*}{$\begin{array}{l}\text { Prot crozoic } \\
\text { (primordial } \\
\text { life). }\end{array}$} & Algonkian. & $(b)$ & $\begin{array}{l}\text { First life that has left distinct record. } \\
\text { Crustaceans, brachiopods, and seaweeds. }\end{array}$ & \\
\hline & Archean. & $\begin{array}{l}\text { Crystalline } \\
\text { rocks. }\end{array}$ & No fossils found. & $50+$. \\
\hline
\end{tabular}

$a$ The geologic record consists mainly of sedimentary beds-beds deposited in water. Over large arcas long periods of uplift and erosion intervened between poriods of deposition. Every such interruption in deposition in any area produces there what geologists term an unconformity. Many of the time divisions shown above are separated by such unconformities - that is, the dividing lines in the table represent local or widespread uplifts or depressions of the earth's surface.

$b$ Epoch names omitted; in less common use than those given. 


\section{PREFACE.}

\section{By George Otis Smith.}

The United States of America comprise an area so vast in extent and so diverse in natural features as well as in characters due to human agency that the American citizen who knows thoroughly his own country must have traveled widely and observed wisely. To "know America first" is a patriotic obligation, but to meet this obligation the railroad traveler needs to have his eyes directed toward the more important or essential things within his field of vision and then to have much that he sees explained by what is unseen in the swift passage of the train. Indeed, many things that attract his attention are inexplicable except as the story of the past is available to enable him to interpret the present. Herein lie the value and the charm of history, whether human or geologic.

The present stimulus given to travel in the home country will encourage many thousands of Americans to study geography at first hand. To make this study most profitable the traveler needs a handbook that will answer the questions that come to his mind so readily along the way. Furthermore, the aim of such a guide should be to stimulate the eye in the selection of the essentials in the scene that so rapidly unfolds itself in the crossing of the continent. In recognition of the opportunity afforded in 1915 to render service of this kind to an unusually large number of American citizens as well as to visitors from other countries, the United States Geological Survey has prepared a series of guidebooks ${ }^{1}$ covering four of the older railroad routes west of the Mississippi.

These books are educational in purpose, but the method adopted is to entertain the traveler by making more interesting what he sees from the car window. The plan of the series is to present authoritative information that may enable the reader to realize adequately the scenic and material resources of the region he is traversing, to comprehend correctly the basis of its development, and above all to appreciate keenly the real value of the country he looks out upon,

\footnotetext{
${ }^{1}$ Guidebook of the western United States: Part A, The Northern Pacific Route, with a side trip to Yellowstone Park (Bulletin 611); Part B, The Overland Route, with a side trip to Yellowstone Park (Bulletin 612); Part C, The Santa Fe Route, with a side trip to Grand Canyon of the Colorado (Bulletin 613); Part D, The Shasta Route and Coast Line (Bulletin 614).
} 
not as so many square miles of territory represented on the map in a railroad folder by meaningless spaces, but rather as land-real estate, if you please-varying widely in present appearance because differing largely in its history and characterized by even greater variation in values because possessing diversified natural resources. One region may be such as to afford a livelihood for only a pastoral people; another may present opportunity for intensive agriculture; still another may contain hidden stores of mineral wealth that may attract large industrial development; and taken together these varied resources afford the promise of long-continued prosperity for this or that State.

Items of interest in civic development or references to significant epochs in the record of discovery and settlement may be interspersed with explanations of mountain and valley or statements of geologic history. In a broad way, the story of the West is a unit, and every chapter should be told in order to meet fully the needs of the tourist who aims to understand all that he sees. To such a traveler-reader this series of guidebooks is addressed.

To this interpretation of our own country the United States Geological Survey brings the accumulated data of decades of pioneering investigation, and the present contribution is only one type of return to the public which has supported this scientific work under the Federal Government.

In preparing the description of the country traversed by the Shasta Route and Coast Line all the geographic and geologic information already published as well as other unpublished material in the possession of the Geological Survey has been utilized, but to supplement this material Mr. Diller made a field examination of the entire route in 1914. Information has been furnished by Dr. F. M. Anderson, Dr. J. C. Branner, Dr. J. Harlen Bretz, Prof. E. S. Burgess, Mr. J. S. Daggett, Mrs. L. P. Diller, Mr. Harold Hannibal, Mr. O. H. Hershay, Prof. A. C. Lawson, Prof. G. D. Louderback, Prof. J. P. Smith, Prof. C. F. Tolman, jr., and Prof. C. E. Weaver, as well as by others to whom credit is given in the text. Railroad officials and other citizens have also generously given their aid, and other members of the Survey have freely cooperated in the work.

For the purpose of furnishing the traveler with a graphic presentation of each part of his route the accompanying maps, 19 sheets in all, have been prepared with a degree of accuracy probably never before attained in a guidebook, and their arrangement has been planned to meet the convenience of the reader. The special topographic surveys necessary to complete the topographic map of the route were made by B. A. Jenkins and J. E. Blackburn. 


\title{
Guidebook of the Western United States.
}

\section{PART D. THE SHASTA ROUTE AND COAST LINE.}

\author{
By J. S. Diluer and others.
}

\section{INTRODUCTION.}

From Alaska to Lower California the western coast of North America is bordered by a belt of mountains which is from 100 to 200 miles wide. This belt as a whole has been named the Pacific System. It separates the Pacific Ocean on the west from an interior plateau region, which also stretches from Alaska to Mexico. This plateau is of varied character but, as is well illustrated by the State of Nevada, much of it is arid and is seamed with mountain rangès.

Attention need be directed here only to that part of the Pacific System which lies chiefly in the States of Washington, Oregon, and California, a section 1,300 miles in length. (See Pl. I.) Within these three States the Pacific System embraces a number of distinct mountain ranges from which project some of the loftiest peaks on the continent. It includes also broad valleys that are in part close to sea level. Consequently it is a region of strong contrasts in altitude and of wide diversity of scenery and climate. Before the snow disappears each summer from the crest of the Sierra Nevada the burning sun in the interior valley of California has yellowed the grain and has tinted the fruit in orchard and vineyard. Throughout the year the snow cap of Mount Rainier is in full sight from the fertile valleys of Washington, where winter severity is unknown.

For its entire extent, from Alaska to Lower California, the Pacific System may in general be divided lengthwise into three parts-two long lines of mountain ranges and an intervening belt of valleys that may be called the Pacific valley belt. The northernmost member of this belt that need be considered here is the valley of Puget Sound. A low divide separates the sound from Cowlitz Valley, the next member of the belt to the south. Cowlitz Valley drains southward to the Columbia and is succeeded on the south by Willamette (wil-lam'et) Valley, whose waters flow northward into the Columbia. Willamette Valley extends southward for about 120 miles, or about halfway across the State of Oregon. Between its head and the north end of the Great Valley of California, the next member of the Pacific 
valley belt, there is a tract of generally mountainous country, where ${ }_{\text {for }} 200$ miles, the threefold longitudinal division of the Pacific System into two ranges and an intervening belt of valleys is less evident than it is elsewhere. South of this interrupting mass of mountains, which is dominated by Mount Shasta, the Great Valley of California stretches for more than 400 miles, having a width in general of 40 to 50 miles. Its northern part, known as the Sacramento Valley, drains southward, and its southern part, known as the San Joaquin Valley, drains northward, Sacramento and San Joaquin rivers both flowing into San Francisco Bay. The south end of the San Joaquin Valley is separated by the transverse Tehachapi Mountains from the Mohave Desert. This in turn is separated by the San Bernardino range from the Salton Basin, which is nothing more than the former upper part of the Gulf of California, the sea, having been excluded by the great mass of sediment dumped into the gulf by Colorado River. By some the Mohave Desert and the Gulf of California are regarded as parts of the Pacific valley belt. By others, however, notwithstanding the general alignment of these features with the Great Valley of California, they are regarded as parts of the plateau region that lies east of the Pacific System of mountains.

As the Pacific valley belt separates in general two parallel ranges of mountains, so these ranges in turn may be subdivided into mountain groups that are sufficiently distinct in form or structure to have received individual names.

At the north end of the western line, between Puget Sound and the ocean, stand the Olympic Mountains, which attain a height of 8,000 feet. Very little is known of their structure or of the rocks that compose them.

South of the Olympic Mountains, stretching along the coast of Washington and Oregon for 350 miles, is a comparatively low range which, to distinguish it from the similarly situated range in California, may be called the Oregon Coast Range. This consists chiefly of rather soft sandstones carrying fossil shells from which it has been determined that the sands were deposited in the sea during early and middle Tertiary time. Lavas associated with these rocks show that volcanoes were active in this region in early Tertiary time. These rocks are no longer in the original horizontal position in which they were deposited but have been crumpled by pressure. Moreover, in some places they have been traversed by long cracks or fissures, and the rocks on one side of a crack have been shoved past the rocks on the other side. The geologist would describe these effects briefly by saying that the beds have been folded, fractured, and faulted.

South of the Oregon Coast Range, partly in Oregon but chiefly in California, are the Klamath Mountains. They are composed of rocks that are older and more complicated in structure than those of the 
Oregon Coast Range and are closely related in materials and in structure to the Sierra Nevada. The Klamath Mountains extend south-southeastward into California for 150 miles and overlap to the east for 80 miles the north end of the California Coast Ranges.

The California Coast Ranges extend southward for more than 600 miles to the vicinity of Point Conception, where the coast turns sharply eastward along the Santa Barbara Channel. They consist of rocks of great variety of character and of widely different geologic ages. Their structure also is exceedingly, complex. The most abundant rocks were formed in the Tertiary, Cretaceous, and perhaps Jurassic periods. Most of these rocks were deposited as sediments on a sea bottom, but associated with the rocks so formed are in places layers of lava or masses of igneous rock, which were forced in molten condition into the sedimentary rocks. All have been folded and faulted at several periods. Finally erosion, or the action of moving water, in the form of rain, streams, and waves, aided by the crumbling effect of weather, carved out the hills as they now appear. The resulting forms reveal to one skilled in their interpretation some indication of the complexity of the underlying rock structure.

At their south end the Coast Ranges meet another set of ranges, which have a more easterly trend than the Coast Ranges proper and do not fall readily into the general threefold division of the Pacific System of mountains that is so clearly recognizable farther north. The suggestion has been made that these mountains should be distinguished from the Coast Ranges, with which they have commonly been included, by designating them the Sierras de los Angeles, from the city of Los Angeles. Well-known individual ranges classed in this group are the Santa Ynez, San Gabriel, and San Bernardino.

Along the east side of the Pacific valley belt stretch two great ranges - the Cascade Range on the north and the Sierra Nevada on the south. The Cascade Range begins a few miles north of the boundary between Washington and British Columbia and continues southward for 650 miles to the vicinity of Mount Shasta in California. It has a foundation of granite and of sedimentary rocks, such as sandstone and shale, ranging in age from Carboniferous to Miocene. Some of the sedimentary rocks and some associated igneous rocks have been changed by heat and pressure into crystalline laminated rocks known as schists. From Mount Rainier southward the rocks just mentioned are buried to an increasing extent under lavas which probably flowed from many vents at different times. The volcanic cones, such as Shasta, Hood, and Rainier, which form striking features of the Cascades, represent a comparatively late stage of volcanic activity and have been piled up on a preexisting mountain range.

The Sierra Nevada, which continues southward the general line of the Cascade Range, is of somewhat different structure and history. It 
is a great inclined block 350 miles long and 80 miles wide, with a gentle slope to the west and an abrupt descent on the east to the deserts of Nevada. This abrupt descent marks a line of faults, east of which the desert country has gone down and west of which, to some extent, the Sierra Nevada has gone up. The Sierra Nevada consists of a great irregular mass of granite which in early Cretaceous time was intruded in a molten condition into sedimentary and older igneous rocks, both of which sets of rocks, in consequence of the heat and squeezing which accompanied this intrusion, were changed in part to schists and slates. After the range had been deeply worn down by erosion, floods of lava were poured over the surface in Tertiary time and the range was tilted up to its present general form. That form, however, has been much modified in detail by comparatively recent erosion and by the canyon cutting of the present streams.

South of the Dominion of Canada three rivers, the Columbia, the Klamath; and the Pit, flow across the Pacific System from the interior plateaus to the ocean. Other large streams, such as the Willamette, in Oregon, and the Sacramento and San Joaquin, in California, flow northward or southward for many miles in one or another of the longitudinal depressions of the Pacific valley belt before turning westward across the western line of mountains to reach the Pacific.

The valley belt is the great agricultural region of the Pacific coast, and in Washington and Oregon, owing partly to its accessibility to ocean-going ships by way of Puget Sound and the Columbia, it contains most of the population. In California, however, the broad fields, orchards, and vineyards traversed by the Sacramento and San Joaquin are rivaled by the many smaller but fertile valleys of the Coast Ranges. The superb harbor of San Francisco sufficiently accounts for the situation of the metropolis; and the rapid growth of Los Angeles, the second city in the State, is due to a combination of shipping advantages with highly profitable kinds of agriculture and extensive resources in petroleum.

Noтe.-For the convenience of the traveler the sheets of the route map in this book are so arranged that he can unfold them one by one and keep in view the one to which the text he is reading relates. A reference is made in the text to each sheet at the place where it should be so unfolded, and the areas covered by the sheets are shown on Plate I. A list of these sheets and of the other illustrations, showing where each one is placed in the book, is given on pages 137-138. $\Lambda$ glossary of geologic terms is given on pages 133-136 and an index of stations on pages 139-142. 


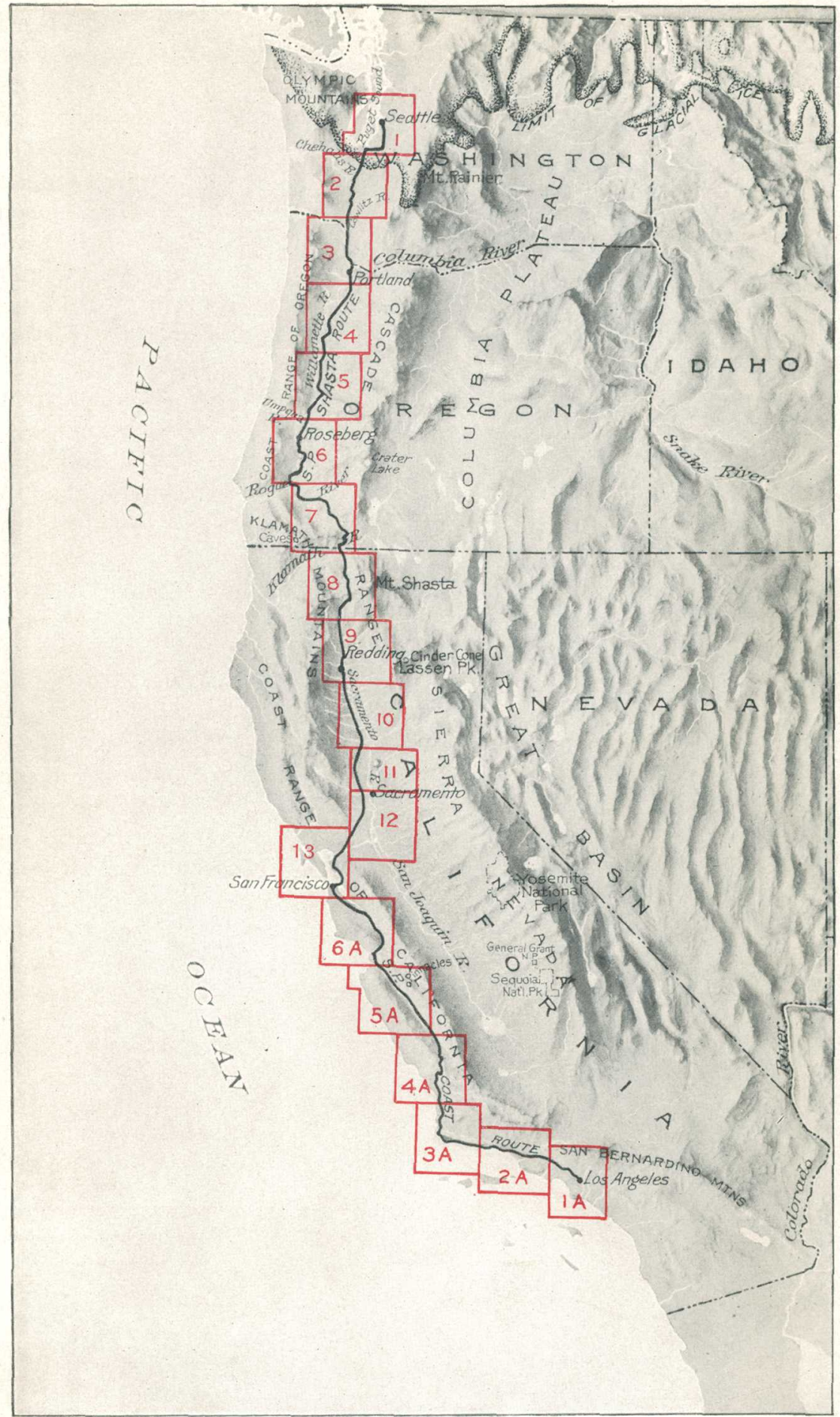

RELIEF MAP OF THE COUNTRY TRAVERSED BY THE SHASTA ROUTE AND COAST LINE. 


\section{ITINERARY.}

\section{SHASTA ROUTE.}

SEATTLE TO SAN FRANCISCO.

On May 11, 1792, Capt. Robert Gray, of Boston, anchored in the great river that he named Columbia, in honor of his ship, and laid the foundation of our subsequent claim to the region Washington. which it drains. The Hudson's Bay Co., whose agents early visited the extreme Northwest, discouraged settlers, but at Tumwater, near Olympia, at the head of Puget Sound, a permanent American settlement was established in 1845 . Marcus Whitman and other missionaries settled near the site of Walla Walla in 1836, but in 1847 Whitman and his wife were killed by the Indians and the station was broken up. Conflicting claims between the United States and Great Britain were adjusted by a treaty July 17, 1846, which fixed the forty-ninth parallel as the international boundary. Oregon, as all this wild country was then called, became a Territory on August 14, 1848, and on March 2, 1853, the part of it north of Columbia River was separated as the Territory of Washington, which was admitted as a State February 22, 1889. The State of Washington has an area of 69,127 square miles and in 1910 had a population of $1,141,990$.

The superb forests of Washington, illustrated in Plate II, are the basis of its chief industries. Within it are 10 national forests, a national park, and a national monument, which together cover more than one-fourth of the State.

Coal is the principal mineral resource of Washington. . In the production of this fuel the State holds first rank on the Pacific coast, the output in 1913 having been $3,877,891$ tons, valued at $\$ 9,243,137$. Wheat, grown chiefly in the eastern part of the State, is the principal agricultural product. Oats and barley are next in importance. Western Washington, which has a moister climate than the eastern part, produces large crops of hay. The fruit industry is developing rapidly, apples in particular finding good markets in the eastern cities and abroad. The waters of the State are full of fish, and the salmon industry is large. The high mountains and heavy rainfall insure abundant water power, which will no doubt be increasingly utilized. 
Seattle (see sheet 1, p. 20), the metropolis of Washington, thc commercial center of the Puget Sound country, and the gateway to Seattle.

Elevation 20 feet. Population 237,194.1 Alaska, stands on a neck of land between Elliott Bay (an eastern arm of Admiralty Bay, Puget Sound) and the fresh-water Lake Washington, about 865 miles by steamer and 957 miles by railroad north of San Francisco. Seattle was founded in 1852 and named after a Duwamish Indian chief. A fire that destroyed almost the whole of the business quarter in 1889 and the financial depression of 1893 retarded for a time the growth of the city, but the discovery of gold in the Klondike region in 1897 gave it a new impulse, as it became the shipping point for the new gold fields. It is the western terminus of three railroads and has direct connections with several others. Its population has nearly trebled in 10 years, and it is now one of the largest and most progressive cities of the Pacific Northwest.

The city is built on a series of terraces, the commercial quarter standing near sea level and the better residential part occupying $\dot{a}$ terrace about 500 feet above the sea. From this part of the city there are fine views not only of the Olympic Mountains and Puget Sound, to the west, but also of Lake Washington and Mount Rainier, to the east. The city has an excellent salt-water harbor, which is being connected by a ship canal with Lake Washington, where vessels may go into fresh water to free their hulls of weeds and barnacles.

The principal exports are coal, timber, hops, and fish. Seattle is the chief point of entry from the Alaskan gold fields, and large quantities of gold dust are brought to the United States assay offices here.

The hills in the lower part of the city have been leveled off by a method used in hydraulic mining; in other words, they have been literally washed away by powerful jets of water. (See Pl. XIV, p. 48.) This method of grading was feasible because the city is built on unconsolidated drift left by a glacier that once occupied the basin of Puget Sound, as described below by W. C. Alden. ${ }^{2}$

${ }^{1}$ The figures given for population throughout this book are those of the United States Census for 1910. For places that are not incorporated the census figures represent the population of the election precinct, township, or other similar unit; such figures are in this book marked with an asterisk $\left(^{*}\right)$.

2 Thousands of years ago, during what is variously termed the Great Ice Age, the glacial period, or the Pleistocene epoch, the northern part of the North American Continent was covered by vast sheets of ice similar to the great ice cap which now covers most of Greenland. (See fig. 1.) Although at times the ice may have coalesced in one vast sheet stretching from the Atlantic to the Pacific and from the Arctic regions southward about to the line of Missouri and Ohio rivers, yet there were three distinct centers of accumulation and spreading. One of these centers was on Labrador Peninsula, one west of Hudson Bay, and one, called the Cordilleran, in the mountains of western Canada. There were also several distinct periods of ice accumulation, each followed by a warmer interval thousands of years in duration, 


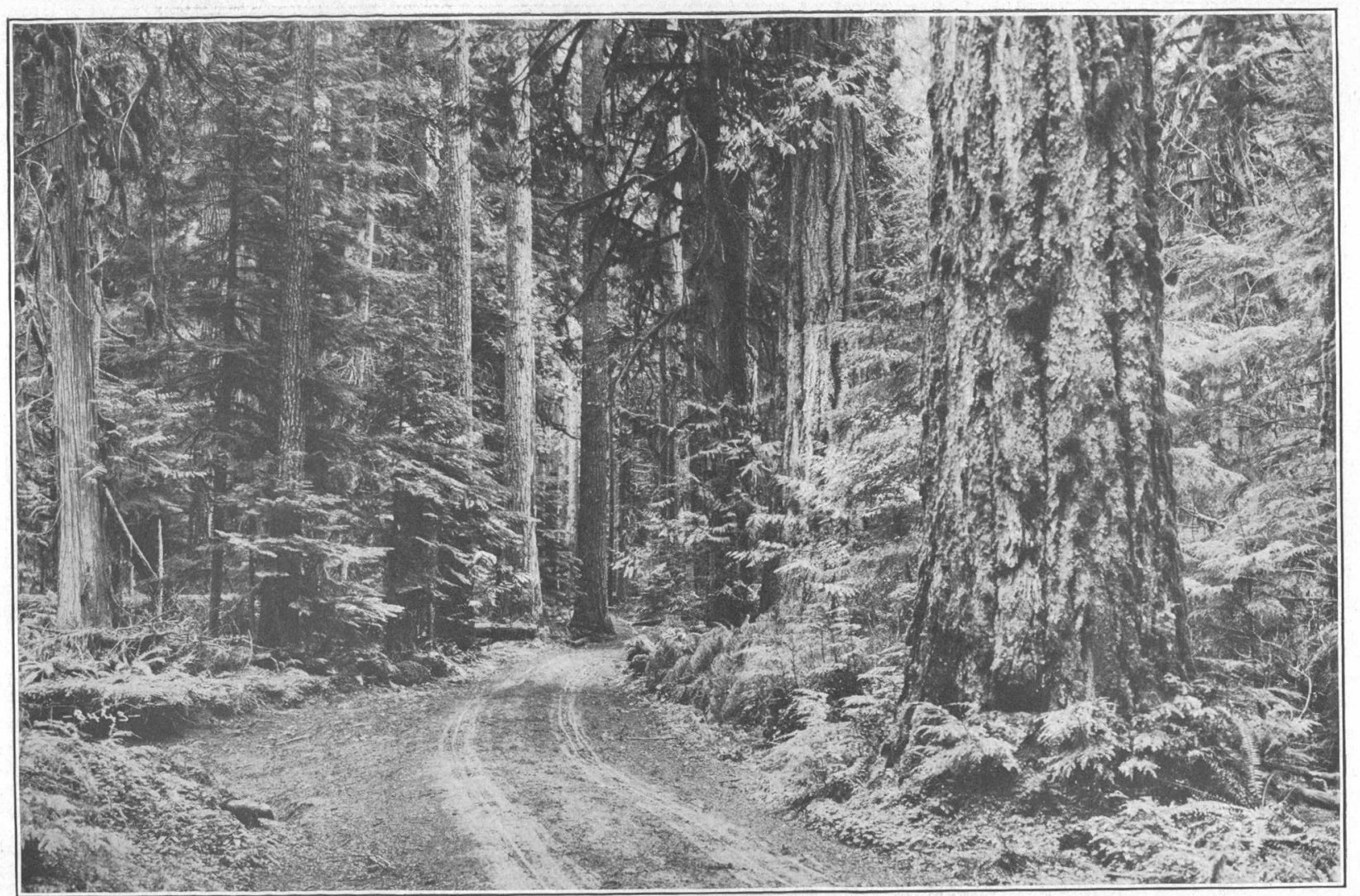




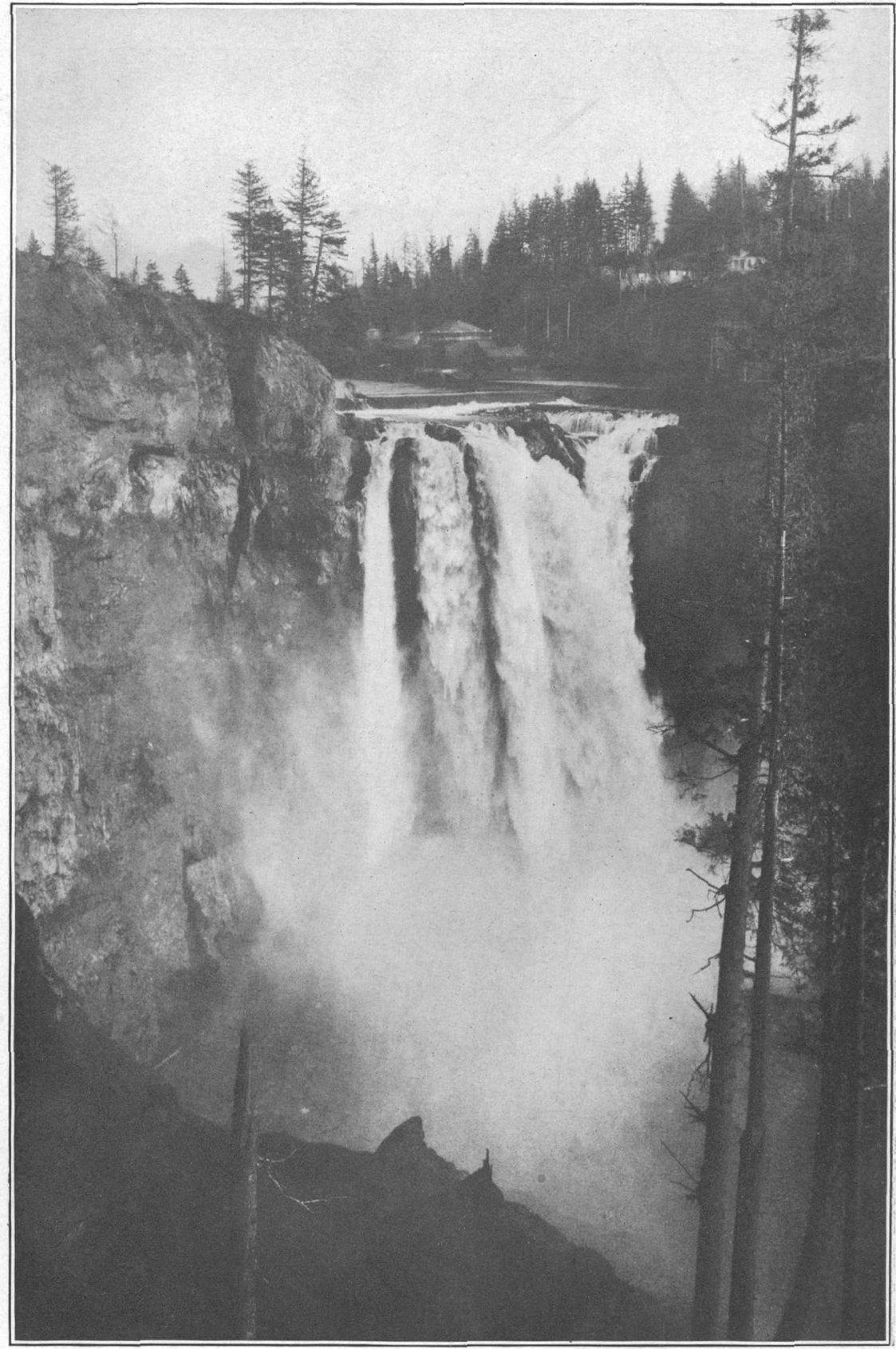

SNOQUALMIE FALLS, WASH.

Height, 268 feet. Falls go over a bluff of ancient lava underlain by sandstone and shale of Eocene age. Photograph by Curtis, Seattle. 
Lake Washington, a beautiful sheet of water near the eastern border of Seattle, is about 20 miles long and 2 to 5 miles wide and is entirely surrounded by glacial drift. Small steamers Excursions from that ply to and fro on the lake afford fine views of
Seattle. the Cascade Range.

Snoqualmie Falls (Pl. III) is 270 feet high and more than 50 feet wide and is well worth seeing. It may be reached by the Northern

during which the ice is believed to have tended southward from British Columbia largely or wholly melted away. There is into the Puget Sound basin. (See P1. I.) evidence of at least four of these distinct The name Vashon, from the large island stages of glaciation, and the last of these between . Seattle and Tacoma, has been is known as the Wisconsin stage. $\quad$ applied by geologists to this ice lobe, the

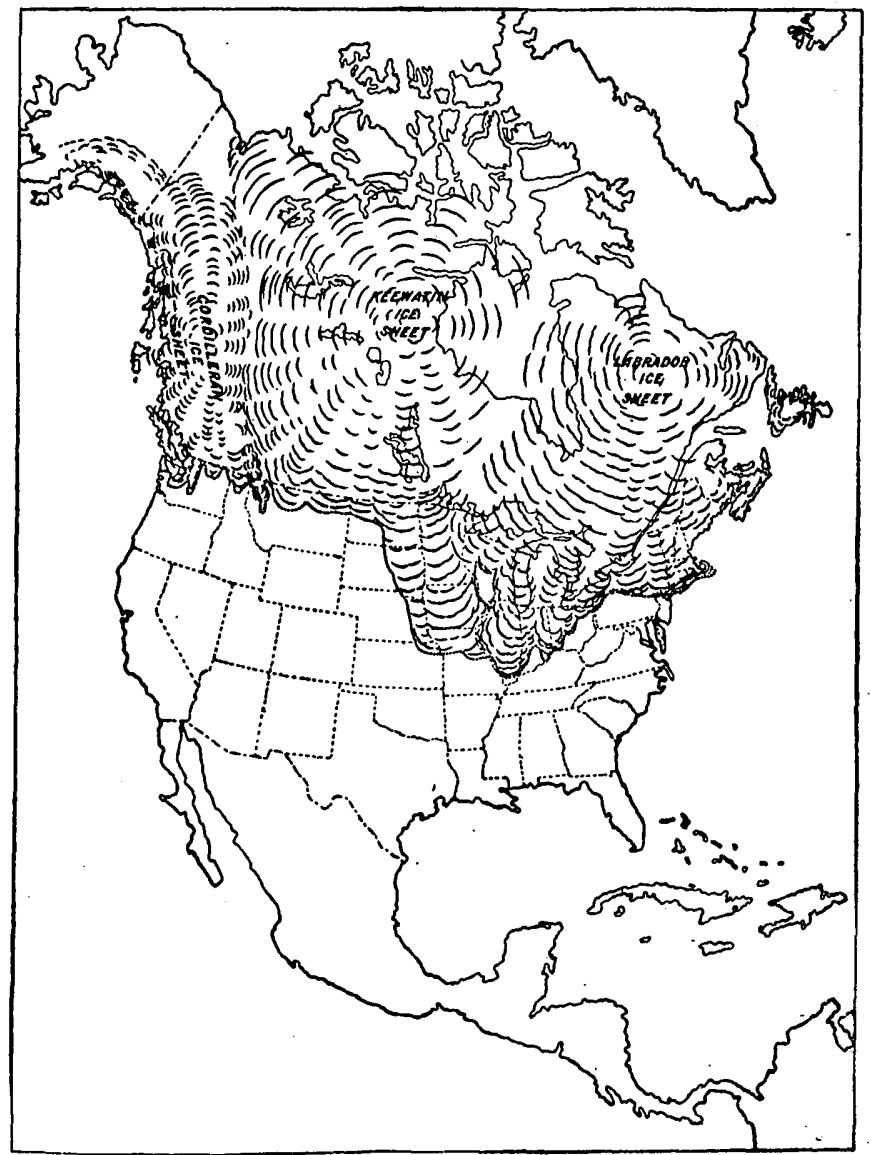

FIGURE 1.-Map of North America showing the area covered by the Pleistocene ice sheet at its maximum extension and the three main centers of ice accumulation.

At a time which probably corresponds 1 last of the Puget Sound glaciers, and to to the Wisconsin stage of glaciation east of the Rocky Mountains the mountains of Washington were largely covered with ice, and a lobe of the Cordilleran ice sheet ex- filled the depressions now occupied by 
Pacific line by way of Woodinville, a trip of 54 miles, or by ferry across Lake Washington to Kirkland and thence by automobile, a route that, for small parties, is generally preferable. At the falls Snoqualmie River plunges over a great mass of lava underlain by fossiliferous sediments of the Eocene coal-bearing formation.

In the immediate. vicinity of Squak Mountain and Sammamish Lake there are a number of large channels cut and then abandoned by streams from the former glaciers. They may be reached by either

the sound, spread over the elevated plains between the valleys, and extended from the foot of the Olymapic Mountains on the west to the base of the Cascade Range on the east. On the south it reached to and covered much of the plains south of Olympia. The ice of this glacier was probably coalescent on the east with that descending the slopes and valleys of the Cascades, to which the name Osceola glacier has been applied by geologists.

These glaciers, on melting, left deposits of clay, sand, gravel, and bowlders (the Vashon and Osceola drift) on the elevated tracts between and around the troughs of the sound, but the deep depressions were unfilled, so that after the ice melted they were occupied by marine waters.

This later drift lies upon stratified sands and gravels (called the Douty gravel, $\mathrm{Pu}$ yallup sand, and Orting gravel) deposited by waters from the melting of earlier glaciers. Buried in these deposits are beds of lignite, formed from vegetation that grew upon the sands and gravels. These older sands and gravels are in places much weathered and eroded; they were evidently exposed during a long interglacial stage before they were overridden and covered by the deposits of the Vashon and Osceola glaciers.

Beneath all these deposits lies a layer of stiff blue clay, mostly stratified but in places showing no bedding and crowded with subangular stones and large bowlders. This deposit (known to geologists as the Admiralty till) is supposed to have been formed at a still earlier stage of glaciation, when the Puget Sound basin was occupied by a lobe of the Cordilleran ice sheet, as it was later by another lobe at the Vashon substage. Some phenomena suggest that glaciers occupied the basin still earlier.
One view as to the origin of the deep troughs composing Puget Sound may be stated briefly as follows: The Admiralty ice sheet occupied and overflowed deep valleys which had been cut when the land stood higher. When this ice melted the hilly tracts between the valleys were uncovered first, and the washing in of sand and gravel leveled these up into what are now the elevated intervalley plains. The final melting of the tongues of ice left the troughs to be occupied by marine water. Later came the ice of the Vashon glacier, and this, on melting, again left the main depressions unfilled.

According to another view the disappearance of the Admiralty glacier left the clay, sand, and gravel spread in a continuous sheet over the Puget Sound basin, burying, in large part, the older valleys and ridges. Afterward the land rose about 1,000 feet and streams cut deep valleys in these soft deposits. Then the basin was depressed about to its present level and the ice of the Vashon and Osceola glaciers filled the valleys and overtopped the intervening tracts, and, on melting, left the area thinly mantled with drift and the depressions unfilled.

As the main outlet of the Puget Sound basin is to the north, ice-dammed freshwater lakes were for a time held in the troughs at each stage of advance of the ice front. When the outlet was at last opened the troughs were filled with marine water, which finally reached the level at which we now find it.

Marine shells found at various levels up to 290 feet above tidewater show that since the disappearance of the glacier of the Vashon substage the basin has been further depressed and submerged and then reelevated. 
of the.routes just mentioned but are best seen southeast of Redmond, where Snoqualmie River once entered Sammamish Lake.

The United States navy yard and huge dry dock at Bremerton, about 20 miles from Seattle, are easily reached by steamer across the Sound. A trip to Hood Canal affords a close view of the densely forested Olympic Mountains. The scenic center of this range is Crescent Lake, reached from Seattle by steamer to Port Angeles, on the Strait of Juan de Fuca, and thence by stage. West of Port Townsend lighthouse, which is passed on this trip, is a bold bluff, 175 feet in height, of stratified glacial sand. Tertiary beds (rich in fossils at Clallam Bay) are well exposed on the southern shore of the Strait of Juan de Fuca. Crescent Lake contains ten varieties of trout, of which two are unknown elsewhere. Mount Olympus, 12 miles away, may be reached from this point with pack outfit. The mountain is a complex mass of metamorphic sandstone, shale, radiolarian chert, glaucophane schist, and greenstone cut by peridotite serpentine, a series of rocks closely resembling what is known as the Franciscan group of the California Coast Ranges.

Between Seattle and Portland trains are operated by the Northern Pacific Railway, Southern Pacific Co., Oregon-Washington Railroad \& Navigation Co., Chicago, Milwaukee \& St. Paul Railway, and Great Northern Railway, the tracks of all these lines being near together. The Shasta Route trains run over the Oregon-Washington and Chicago, Milwaukee \& St. Paul tracks from Seattle to Tacoma, and over the Northern Pacific from Tacoma to Portland.

On leaving Seattle the train first traverses made land, built out into Puget Sound by washing glacial gravels through flumes from the adjacent hills. A turn to the left, ${ }^{1} 2.3$ miles from Seattle, brings into view a bluff of whitish shales and sandstones. These rocks are exposed for only a short distance at this place, but a mile farther south they reappear in a more prominent bluff just north of Georgetown.

These rocks, which were once sediments on a sea bottom, contain abundant fossil sea shells that indicate Tertiary (middle Oligocene)

Georgetown (Argo).

Elevation 20 feet.

Seattle 3 miles. age. The exposure of the beds at this place is due to their having been arched up from their originally horizontal attitude. This arch, or anticline, as geologists term it, may be traced, as shown on the map, from Bainbridge Island southeastward to and beyond Lake Washington.

Some greenish rocks that form a bluff on the left are composed largely of fragments of volcanic material. These beds are fossilif-

${ }^{1}$ Unless clearly otherwise intended, / track as they appear to a traveler facing the words right and left as used in this the engine in going from Seattle to San bulletin refer to the sides of the railway Francisco. 
erous near the wagon-road bridge at Steels Crossing. They belong to the principal coal-bearing formation of Washington, presently to be described, and are associated with lavas. At Steels Crossing the railroad enters the coal field of western Washington, the largest in the State. The productive portions of the field, however, are miles away, northeast and southeast of this point, about Newcastle and Issaquah, Black Diamond and Franklin, Wilkeson and Carbonado. The field contains, many coal beds, three or four of which have been mined, in places to a depth of 2,000 feet. The coal ranges from low-grade subbituminous to anthracite but is mainly subbituminous and bituminous. Coking coals occur at a number of localities and are worked in the Wilkeson region. They are the only coals coked commercially on the Pacific coast.

The fossil plants that are associated with the coal and that represent the vegetation from which the coal was formed contrast strongly with the plants of this region to-day. In the present forest conifers are dominant in size and number, but in the forests of the Eocene coal period conifers were few and palms and deciduous trees were abundant. No palms now grow, wild within a thousand miles of the Puget Sound region, so the climate here during the coal period must have been very unlike that of to-day. The coal-bearing rocks crop out at intervals along the western base of the Cascade Range from the international boundary on the north to the Columbia on the south.

The railroad crosses Black River, the outlet of Lake Washington, at Black River Junction, from which branch lines lead to the Newcastle, Renton, and Black Diamond coal fields. Black River Junction. The mine at Renton is only 2 miles to the east Elevation 39 feet. Population 519.* Seattle 10 miles. (left) of Black River Junction. Two beds are mined here. The thicker one is 2 feet $8 \frac{1}{2}$ inches thick and inclines or dips southeastward at an angle of $12^{\circ}$. The coal is subbituminous.

From Seattle to Tacoma the railway follows a broad valley in glacial drift which forms the bluffs on both sides. This valley, which is continuous from Duwamish River to the Puyallup, was left by the melting of the ancient glacier as one of the intricate series of depressions now occupied in part by Puget Sound. It was later partly filled with silt, sand, and gravel by the mountain streams. White River, which enters the valley on a low deposit of gravel and sand which it has itself built up south of Auburn, separates on this sloping deposit, or alluvial cone, into two streams. One, which retains the name White River, flows northward into the Duwamish, and the other, called Stuck River, turns to the south and joins the Puyallup. This division of a stream on the sloping surface of its own deposits tells the story of a long period of successive floods carrying heary loads of gravel and sand into this old depression. The later floods 
have spread over the valley the fine silt to which its remarkable fertility is due. A generalized section of the valley is shown in figure 2.

The dominant industry in the vicinity of Kent is dairying, and herds of Holstein cattle may be seen in the fields. There are condensed-milk factories at Kent and Auburn, and the

\section{Kent.}

Elevation 40 feet. Population 1,908. Seattle 17 miles. two have a combined average daily output of about 96,000 cans, or 25 carloads. The red-berried elder (Sambucus callicarpa), a showy shrub in June, is likely to attract the traveler's attention along this Auburn.

Elevation 74 feet. Population 957. Seattle 22 miles. part of the route. On the left, a mile away, is the bluff of the great gravel pit of the Northern Pacific Railway, which shows the structure of the ancient delta of Green River. Near the pit are the Northern Pacific transfer yards, containing 37 miles of track.

On the east (left) side of the valley, 3 miles northeast of Sumner, is the power plant of the Puget Sound Light \& Traction Co., where water drawn from Lake Tapps, on the upland a few miles to the southeast, develops 80,000 horsepower.

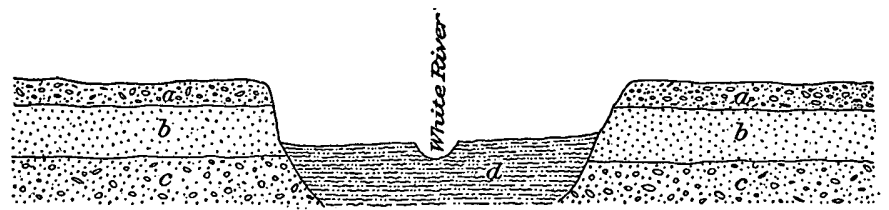

FIGURE 2.-Generalized section of White River valley at Kent, Wash., showing alluvium-filled depression in glacial deposits, including (a) Vashon drift, (b) Orting gravel, (c) Admiralty drift, and (d) deposits of present stream.

As Sumner is approached a yeast factory can be seen on the left. Sumner.

Elevation 70 feet. Population 892.

Seattle 29 miles.

On the right, near the station, is the gravel pit of the Chicago, Milwaukee \& St. Paul Railway, which shows the general composition of the gravel cliffs inclosing the valley.

The Sumner and Puyallup country, once noted for its hops, is now better known for its fresh and canned fruit, especially raspberries and blackberries. Here the Cuthbert red raspberry reaches perfection and is grown in enormous quantities. The Puyallup \& Sumner Fruit Growers' Association, consisting of 1,400 growers, has its own refrigerating plant and in 1913 shipped 600 cars of fresh fruit to the eastern markets.

Puyallup is the home of Ezra Meeker, a pioneer who in 1852 with an ox team crossed the plains and mountains to Puget Sound. In North Puyallup.

1906 he returned by the same means of conveyance Seattle 31 miles.

from Puyallup to New York City, marking the Oregon Trail at many points by monuments. The brilliant yellow flowers of the gosmore, or cat's ear (Hypochæris radicata), a near relative of the dandelion, abound by the wayside. At North Puyallup, with its berry farms, the railroad enters the Puyallup 
Indian Reservation and crosses the valley. As Taooma is approached the Indian School for Trades may be seen on the left.

Tacoma is the western headquarters and the official tidewater terminus of the Northern Pacific Railway. It is beautifully situated on a series of terraces rising about 300 feet above the

Tacoma.

Population 83,743. head of Commencement Bay, the southeast arm of Seattle 41 miles. Puget Sound, and commands fine views of the Sound, the Cascade Mountains, and the white cone of Mount Rainier (Pl. IV, $A$ ). Its industrial establishments include a lead smelter and refinery, large sawmills, furniture factories, foundries, railway shops, and flour mills. Tacoma carries on an extensive commerce in grain, lumber, coal, tea, silk, and other articles. In the courthouse is the Ferry Museum, which contains, among other: things, an interesting collection of Indian baskets, domestic utensils, canoes, and implements of hunting and war.

Tacoma is a subport of entry (Port Townsend is the official port) and is second only to San Francisco in the volume of its foreign trade. It has an excellent harbor and 25 miles of water front, and from it transoceanic steamship lines run to Japan and China, to the Philippines and Hawaii, and to London and Glasgow.

Capt. George Vancouver visited the site of Tacoma in 1792, and Lieut. Charles Wilkes surveyed it on his exploring expedition in 1841. Gen. Morton Matthew McCarver founded the present city in 1868. It was at first called Commencement City, but fortunately the name was later changed to Tacoma, an Indian word meaning "big snow mountain" and referring to Mount Rainier.

The principal excursions from Tacoma go to Mount Rainier, which is reached either from the northwest by way of the Excursions from Wilkeson coal field or from the south by way of Longmire Springs and Paradise Park.

Tacoma.

The great naturalist John Muir has justly termed the mountain parks "fountains of life." Appreciation of the beautiful in nature should become more and more an American characteristic, and in these days of national stock taking we do well to inventory as part of the nation's wealth its resources in wild scenery.

The Mount Rainier National Park is unique in possessing the wildest of mountain scenery almost at the gates of two large cities. Less than half a day's travel by rail and stage from Tacoma brings the visitor to the hotel at Longmire Springs, well within the park, and the perfectly graded Government road enables him to reach the lower end of the Nisqually Glacier. Just beyond is Paradise Park, where a tent hotel affords accommodations amid beautiful surroundings at the starting point for the ascent of the mountain. 


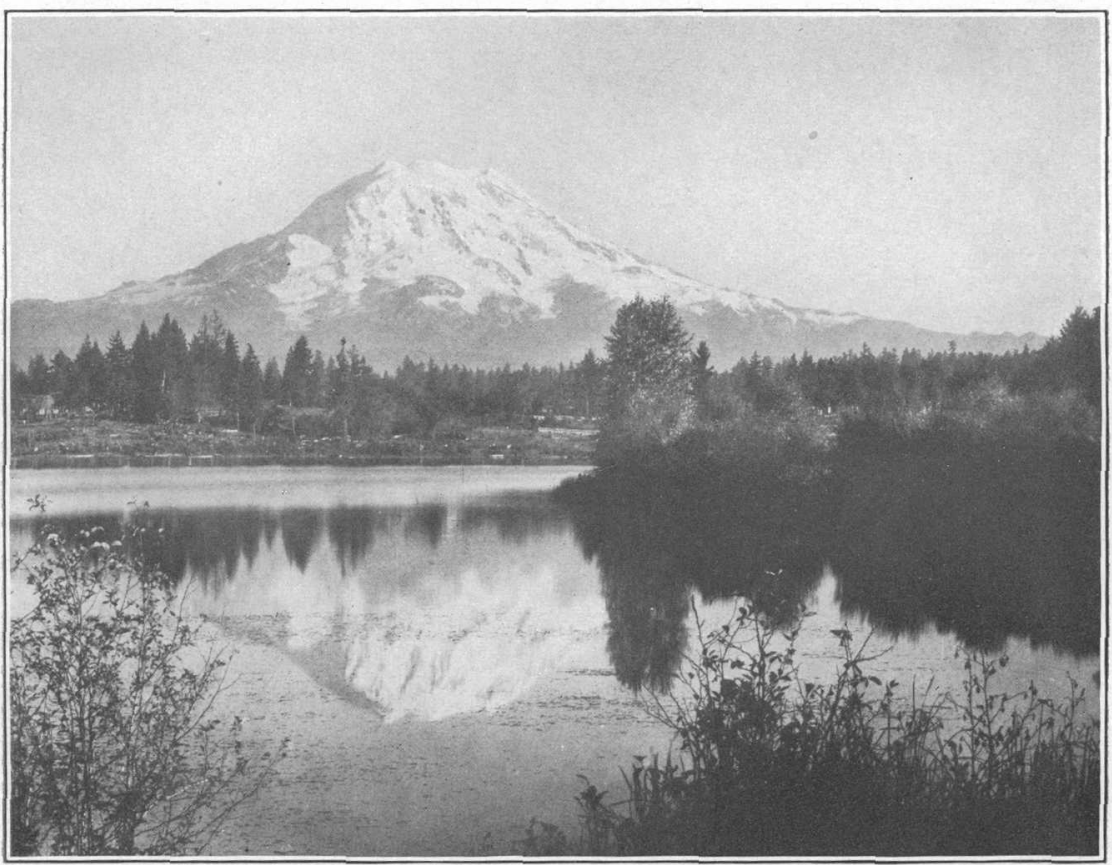

A. MOUNT RAINIER, WASH., FROM SPANAWAY LAKE.

Mount Rainier is an extinct volcano 14,408 feet in height. It is a huge pile of lava (chiefly andesite) resting on a plateau of Tertiary and older rocks. Photograph copyrighted by Barnes, Parkland, Wash.

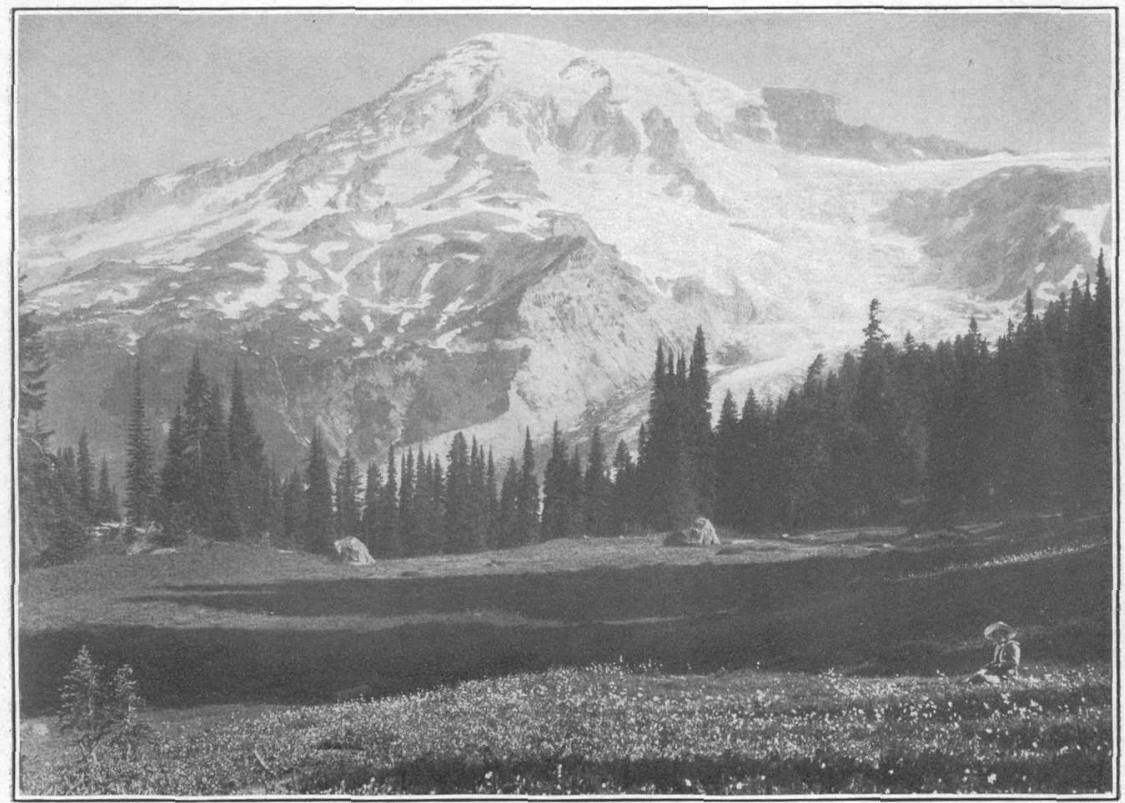

B. PARADISE PARK, ON SOUTH SLOPE OF MOUNT RAINIER,

Elevation, 5500 feet. The rock at the right of the summit is Gibraltar. Beyond the forest is the Nisqually Glacier, at the head of Nisqually River. Photograph by Curtis \& Miller, Seattle. 


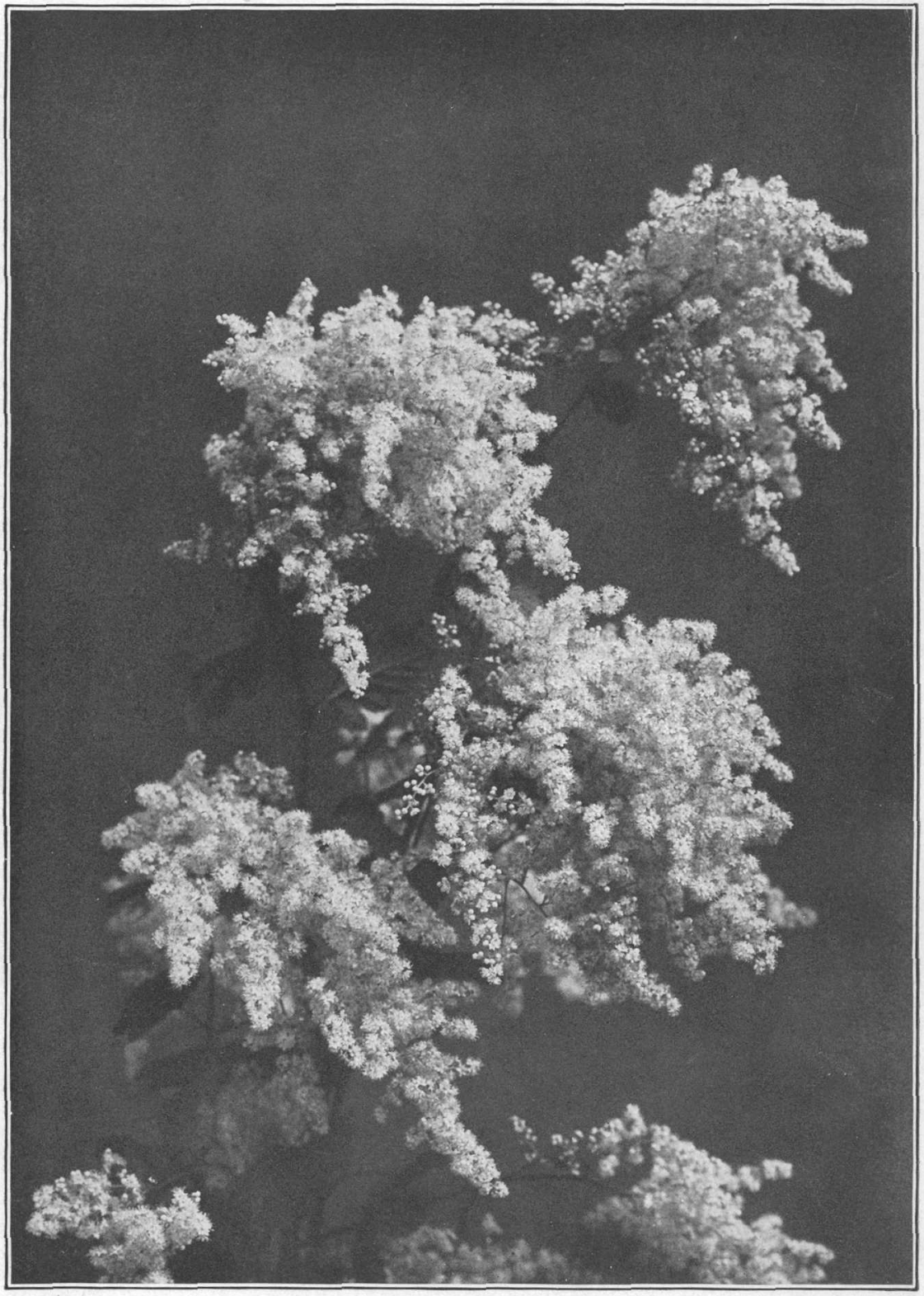

OCEAN SPRAY (SERICOTHECA DISCOLOR), A COMMON FLOWER IN WASHINGTON.

Sometimes called arrowwood, because the branches are used by the Indians in making arrows. Photograph by Barnes, Parkland, Wash. 
Mount Rainier is the noblest of the peaks that overlook our Pacific coast. It attains an elevation. of 14,408 feet and is the highest peak of the Cascade Range. Like Fujiyama in Japan and Shishaldin in Alaska, it rises majestically with the graceful lines that proclaim its volcanic origin. Its base is set in the green of the wonderful Puget Sound forest, and its snowy cone merges into the clouds, to which it appears to belong rather than to the earth. From this cone a score of radiating glaciers, the largest in the United States, extend down the gashed slopes into the forest below, where they give rise to rushing, roaring rivers of milk-white water. Over 25 years ago James Bryce, later British ambassador to this country, and Karl von Zittel, the well-known:German geologist, visited Mount Rainier, and in a report expressed the hope that this peak might be reserved as a national park. It is gratifying to Americans to know that these experienced and discriminating travelers said that they had seen nothing "more beautiful in Switzerland or Tyrol, in Norway, or in the Pyrenees than the Carbon River glaciers and the great Puyallup glaciers."

In Paradise Park (Pl. IV, $B$ ), or in some other sylvan retreat on the lower slopes of Mount Rainier, whoever is weary of ihe city may find true recreation. All about are bright flowers, which throughout the summer follow the retreating snowbanks in a succession of gardens wherein nature displays a profusion of bloom alongside of ice and snow. Below are the forests, dark and almost silent, except where their stillness is broken by the raucous cry of the Clark crow or where some stream roars over the bowlders or splashes musically among the ferns. Above all looms the peak, clad in eternal snow.

The volcanio cone of Mount Rainier has been built up by lava erupted through past ages. Although it is practically extinct, its crater still gives forth steam and sulphurous fumes. The form of the cone has been modified by the destructive work of glaciers, which have cut deep grooves into the mountain sides, and of avalanches, whose occasional thunder testifies to the continued attack of atmospheric agencies.

Mountain goats, marmots, and ptarmigan constitute the fauna of the mountain.

To aroid some heary grades the Northern Pacific Co., by tunneling Point Defiance and continuing thence by way of Steilacoom, has recently built a new line from Tacoma to Tenino, commonly known as "the loop," thus enabling the traveler to enjoy some coast scenery. This line is 6 miles longer than the old line, but the easier grades offset the difference in distance. From Tacoma the new line follows the shore northwestward for 4 miles, past the flour and saw mills to the $96286^{\circ}-$ Bull. $614-15-2$ 
lead smelter, affording a good view of Commencement Bay and of the harbor of Tacoma on the right. In the bluffs on the left rudely stratified cross-bedded sand and gravel (Puyallup substage) rest at several points on evenly stratified clays and fine sands with local pockets of gravel and bowlders of the earlier (Admiralty) stage of glaciation. The first good example is on the left, 2 miles from the Tacoma union station, where an arch of the clay beds brings them plainly into view, as shown in figure 3 .

Four miles from Tacoma, near the smelter tunnel, on the left, is a deep clay pit exposing the same formations in the same relative position, but just beyond, at the entrance of the main tunnel, there are on both sides of the cut beds of well-stratified clay and fine sand with patches of gravel lapping up over irregularly stratified and crossbedded sand and gravel. The tunnel is 4,400 feet in length and 275 feet in greatest depth. In excavating it no hard rocks were cut, but a large tooth, probably of a mastodon, and traces of coaly material were found in sand associated with gravel.

From the west portal the run along the

Figure 3.-Section of bluff 2 miles north of station at Tacoma, Wash., showing (a) an arch of finely stratified sand and clay of the Admiralty glacial drift, overlain by $(b)$ irregularly stratified gravel and sand of the Puyallup substage. shore for 15 miles affords splendid views of the Narrows and the Olympic Range beyond. Puget Sound has 1,750 miles of shore line, with shelving beach, precipitous cliffs, and dense forests, affording some of the most beautiful inland water views in America. The seepage of much water in many places along a line about 120 feet above low tide marks the contact of stratified clays and overlying gravel and causes the railway much trouble from slides.

As Steilacoom is approached the traveler's attention is likely to be attracted by the pits on the left, from which large quantities of gravel are loaded on scows for shipment to Tacoma and Seattle. The loading is done by an application of the hydraulic method, first devised in placer mining. The gravels as exposed in the pits show distinctly the double set of bedding planes characteristic of delta deposits, namely, a series of beds that dip rather steeply in the direction of the river's flow (foreset beds), overlain by a series of nearly horizontal layers (topset beds). The delta was built out into Lake Russell while the Puget Sound glacier was melting.

Steilacoom is one of the oldest settlements in the western part of the State. A monument placed here in 1908 marks the site of the first Protestant church building erected north of the

\section{Steilacoom.}

Population 430. Seattle 60 miles. yellow blossoms form a pleasing feature of the landscape.

Columbia. It was built in 1853. Scotch broom (Genista scoparia), which has been introduced into this region, flourishes about Steilacoom, and its bright 
Beyond Ketron the water view widens. The horizontally stratified sands and gravels that have been the prevalent material along the Ketron. railway for miles are well developed and within view Seattle 62 miles. on Ketron and Anderson islands. The dark-spotted rock used to protect the railroad embankment from the southwest storms of winter comes from the vicinity of Bremerton and contains a few fossil shells. Porpoises, seals, and even whales may occasionally be seen in this part of the Sound. A whale stranded near Steilacoom in 1912. At the mouth of Sequalitcher Creek are the wharf and power house of the Dupont powder works, which are just out of sight on the left. The foreset bedding of the old delta gravels is well shown for $3 \frac{1}{2}$ miles along this portion of the route. These gravels are succeeded abruptly at 22.1 miles from Tacoma by wellexposed stratified clays (Admiralty) overlain by stratified gravels.

At the mouth of Nisqually River a strip of the present delta nearly a mile wide is alternately covered and left bare by the tides. Three miles up the river valley is Nisqually station, where Nisqually.

Population 497.* the main line is crossed by the Grays Harbor branch Seattle 68 miles. of the Northern Pacific, leading to Olympia, the State capital, and beyond to the coast. From Olympia another branch runs through Tumwater, the oldest American settlement in Washington, which marked the end of the Oregon Trail.

Near Nisqually station there is a small terminal moraine left by the receding front of the Puget Sound glacier. South of Nisqually River are delta gravels which were deposited by a former stream on the great outwash plains left by the melting glacier. These gravels are well exposed in the railway cut. Near the Nisqually are obtained some of the best forest views on the route. Almost all the lands of the Seattle-Tacoma region except the cultivated river valleys are still forested. The dominant forest tree is the red fir, which covers fully 90 per cent of the heavily timbered area, in places with a stand so dense that the sun can scarcely penetrate to the soil. In a narrow strip along the coast the dominant species is the Sitka or tideland spruce. In the bottom lands, mainly river valleys, the conspicuous trees or shrubs are the red cedar, giant cedar, white fir, large-leaved maple, Oregon ash, cottonwood, western dogwood, vine maple, crab apple, various willows, devil's-club, and salmon berry. On the gravelly plains may be seen the only species of oak growing in the State, the black pine, and from spring until the middle of July a carpet of brilliant flowers.

The material of the terminal moraine southeast of Olympia is best exposed in the area surrounding Patterson Lake. The railway cuts Kyro. are not deep, however, and are therefore not very Seattle 71 miles. satisfactory to the geologic observer. The open prairies on the glacial outwash plain (that is, the plain formed by gravel washed from the front of the glacier) begin near Kyro. They present a sharp contrast with the dense forests 
around them and are probably due to some peculiarity of soil or drainage that is unfavorable to forest growth. Several miles beyond is Chambers Prairie, which is 2 miles north of the railroad station of the same name. (See sheet $2 ;$ p. 24.) From this prairie excellent views may be obtained of Mount Rainier, in the rear, to the left, and of the Black Hills, ahead, to the right. Just before Plumb is reached there is another fine view of Mount Rainier, across a meadow.

Plumb.

Seattle 81 miles.

At milepost 38 the railway enters Rocky Prairie, which is notable for its curious mounds. The origin of these mounds has been fully discussed by Prof. J. H. Bretz, of the University of Chicago, who concludes that they are not the result of erosion, as some have thought, but that the gravel of which they are composed was deposited in hummocks. Similar mounds are abundant on some other prairies.

After traversing another belt of terminal moraine and of hills composed largely of Tertiary shales the railway enters Tenino, which

\section{Tenino.}

Elevation 280 feet. Population 1,038.

Seattle 87 miles via Plumb; 81 miles via Yelm. stands near the end of a projecting spur of the Cascade Range. On the right, near the station, is a quarry of a sandstone that is widely known to builders in the Northwest as the "Tenino sandstone." It is generally fine grained, well cemented, and easily worked, and has the valuable property of hardening after being quarried. The high school and Trinity Church in Seattle are built of this sandstone. The rock is of Eocene age. About a mile north of Tenino, near the old line of the Northern Pacific, is a large quarry in the same sandstone, from which the Government has obtained rock for the Grays Harbor jetty.

The Puget Sound glacier, of the Vashon substage, is believed to have had its southern boundary, at its time of greatest extension, near the line where the prairies end against the timbered hills south of the town. There is, however, no terminal moraine marking this limit for some miles east or west of Tenino.

At Tenino the railway is joined by the old line of the Northern Pacific from Tacoma. This line passes through much prairie country on the great outwash gravel plain formed by the melting of the Puget Sound glacier. A few miles north of Hillhurst and at Yelm the traveler may enjoy fine views of Mount Rainier.

As Bucoda is approached the valley widens. The railway crosses Skookumchuck River (the name is Chinook for "strong water") and

\section{Bucoda.}

Elevation 256 feet. Population 855.* Seattle 84 miles. ${ }^{1}$ runs between bluffs of coal-bearing Eocene sandstone on the left and the river on the right. Just south of Hannaford Creek the beds in the bright-red cliff on the left stand vertical. The brilliant colors have the effect of a burned coal bed. Waters flowing from the Puget Sound

${ }^{1}$ Distances by the old line are given for stations beyond Tenino, and to get the distance actually traveled from Seattle by the new line 6 miles should be added. 


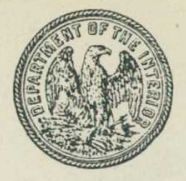

GEOLOGIC AND TOPOGRAPHIC MAP OF THE

\section{SHASTA ROUTE}

From Seattle, Washington, to San Francisco, California Base compiled from United States Geological Survey Atlas Sheets, from railroad alignments and profiles supplied by tion collected with the assistance of this company

UNITED STATES GEOLOGICAL SURVEY GEORGE OTIS SMITH, DIRECTOR

David White, Chief Geologist $\quad$ R. B. Marshall, Chief Geographer

1915 Each quadrangle shown on the map with a name in parenthesis in the
lower left corner is mapped in detail on the U.S. C.S. Topographic
Sheet of that name.

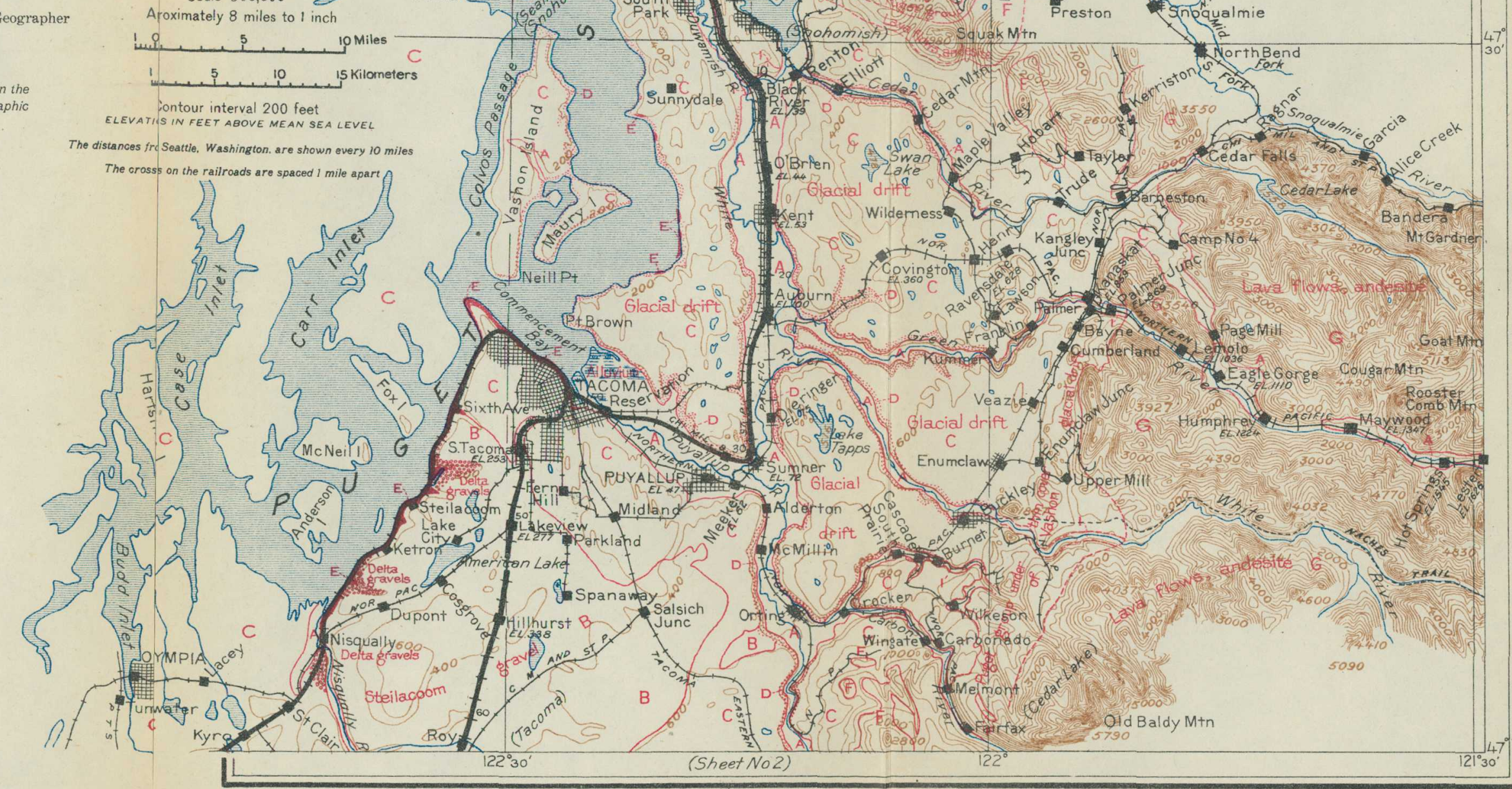


glacier found an outlet down this valley as far as Centralia and thence went northwestward by way of the Chehalis River valley.

Centralia, about a mile above the mouth of the Skookumchuck, is an important railway junction and the center of a large lumber industry. The town is also becoming a coal-mining Centralia.

Elevation 188 feet. Population 7,311. Seattle 91 miles. center, and much attention is given to dairying and to the growing of small fruits, especially strawberries. The coal-bearing rocks, of Eocene age, lie east of the town. The beds to the west (Astoria shale) are Oligocene, and are succeeded by still younger formations toward the coast.

Below Centralia the Skookumchuck enters the broad valley of the Chehalis, a river which drains a section of the Cascade Range and flows across the Coast Range to the Pacific at Grays Harbor. Two railway lines, a branch of the Northern Pacific and a line of the Oregon-Washington Railroad \& Navigation Co., connect Centralia with the coast by way of Chehalis Valley.

Chehalis is the center of a large dairying district and has a condensed-milk factory. A branch line runs west from this place to South Bend. The State Training School stands on

Chehalis.

Elevation 188 feet. Population 4,507. Seattle 95 miles. a terrace formed by gravel with soft decomposed pebbles, which is well exposed in several street cuttings a few blocks west of the railway station and at many other points farther down Chehalis River, especially at Satsop. These gravels were deposited during the early part of the Pleistocene epoch by the floods from the melting glaciers.

South of Chehalis the river is joined by Newaukum River. The valley at their confluence is broad and fertile and contains many thriving farms, chiefly on the left. A group of yellow monkey flower (Mimulus) brightens the wayside in spring and summer. Other plants likely to attract attention are the thimbleberry, with its white blossoms; the salmonberry, with its yellow fruit; the pink fireweed; the white, plumose, gracefully pendant ocean spray, or arrowwood (Sericotheca discolor, Pl. V, p. 17); and other forms growing among larger plants on the wooded slopes. In the more open ground the almost omnipresent dandelion in June, with its fluffy crowns of seeds, the purple lupine, the red and white clover, the white yarrow, and a host of other flowers give the beauty of varied coloring to the views in this forest land.

From Seattle to Portland the great forests of Washington are almost continuous. The exceptions are the so-called prairies of the outwash gravel plains; the great stretches, bristling with the blackened trunk of many a forest monarch, which the lumbermen leave in their wake; and the long alluvial valleys which the farmer has cleared and tills. Alder and maple are the usual successors to the firs in the valleys. 
Beyond Chehalis the railway gradually ascends through shallow cuts in Eocene sandstone and early Pleistocene gravel to Napavine, situated near the crest of a low east-west divide ( 450 Napavine.

Elevation 444 feet. Population 1,304.* Seattle 103 miles. feet above sea level) that separates Chehalis River from the Cowlitz, a tributary of the Columbia. The broad surface of the divide is the level top of an extensive deposit of gravel that is well exposed in the cuts along the railway. In this locality the gravel consists largely of volcanic materials, the white quartz pebbles that are so common in many gravels being absent. About 3 miles beyond Napavine, near Evaline, may be seen the brownish Eocene sandstone which underlies the gravel.

The railway crosses Olequa Creek, along which is a well-developed bench or terrace eroded in the same gravel formation that was seen near Napavine. A similar terrace, at a corresponding height above the stream, is a prominent feature of the Cowlitz, Willapa, and other valleys in southwestern Washington. A bluff of the same gravels, here 150 feet in thickness and overlying Oligocene beds, appears on the left as Winlock is entered.

Winlock is commonly known as "Bungalow Town" and the station has been built in that style. About 3 miles

\section{Winlock.}

Elevation 309 feet. Population 1,140. Seattle 109 miles. beyond Winlock the valley opens and on the right a fine view is obtained of Abernathy Mountain, a spur of the Coast Range. On the left are some remarkably tall alders with a background of firs.

Near Vader station are tile ovens, which are supplied by clay obtained near by. A mile beyond the town, on the right, is a small Vader.

Elevation 143 feet. Seattle 116 miles. gas plant. The gas is made from the slabs rejected by the adjacent sawmill and is supplied to the town at the rate of $\$ 3$ a month for five lights and a kitchen stove. The salable by-products of the gas plant are pyrogallic acid, creosote, tar, and charcoal.

Olequa Creek is again crossed and the train enters a short gorge. On the left, by looking ahead down the gorge, the traveler may get a fine view of the snow-covered top of Mount St. Helens, standing above deep-green forests of fir. Nearer at hand, on the left, a bluff exposes a sheet of lava overlying Eocene shales, ${ }^{1}$ and on the right are Pleistocene sands.

${ }^{1}$ This is the region of the type section of the Olequa formation, described by Arnold and Hannibal as extending from the Ewing ranch, 2 miles above Little Falls [Vader], southward down Olequa Creek to Olequa, a distance of $5 \frac{1}{2}$ miles. 


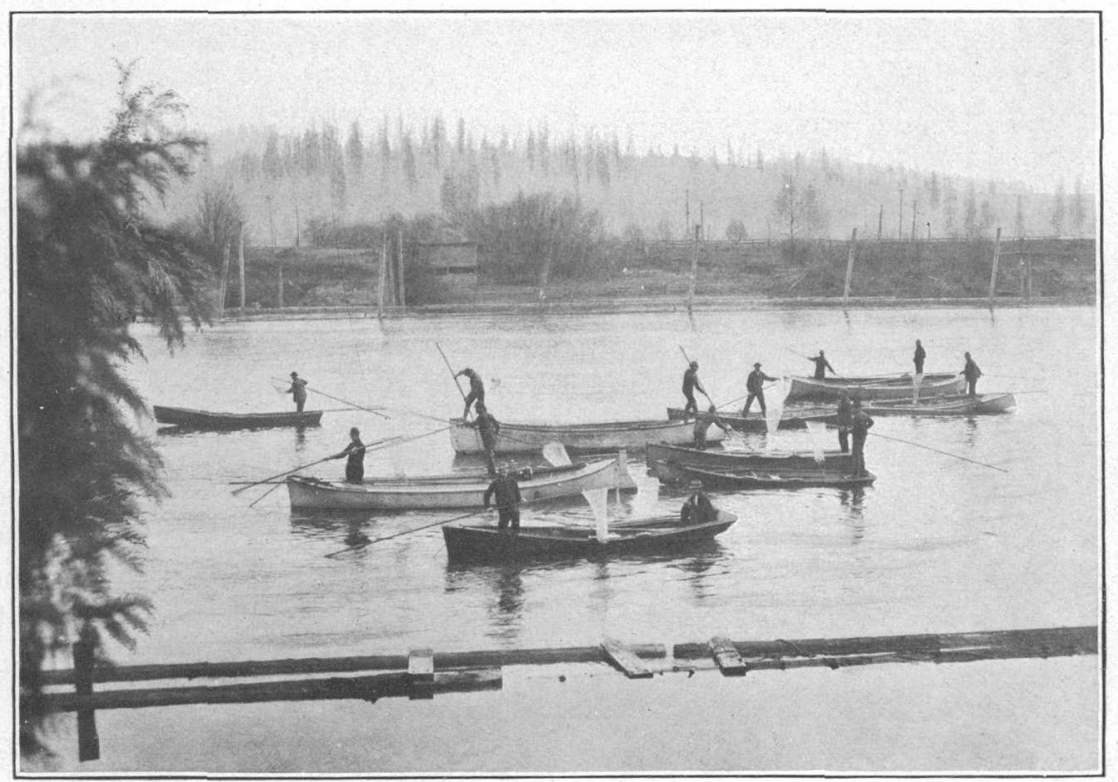

A. SMELT FISHERY ON COWLITZ RIVER NEAR KELSO, WASH.

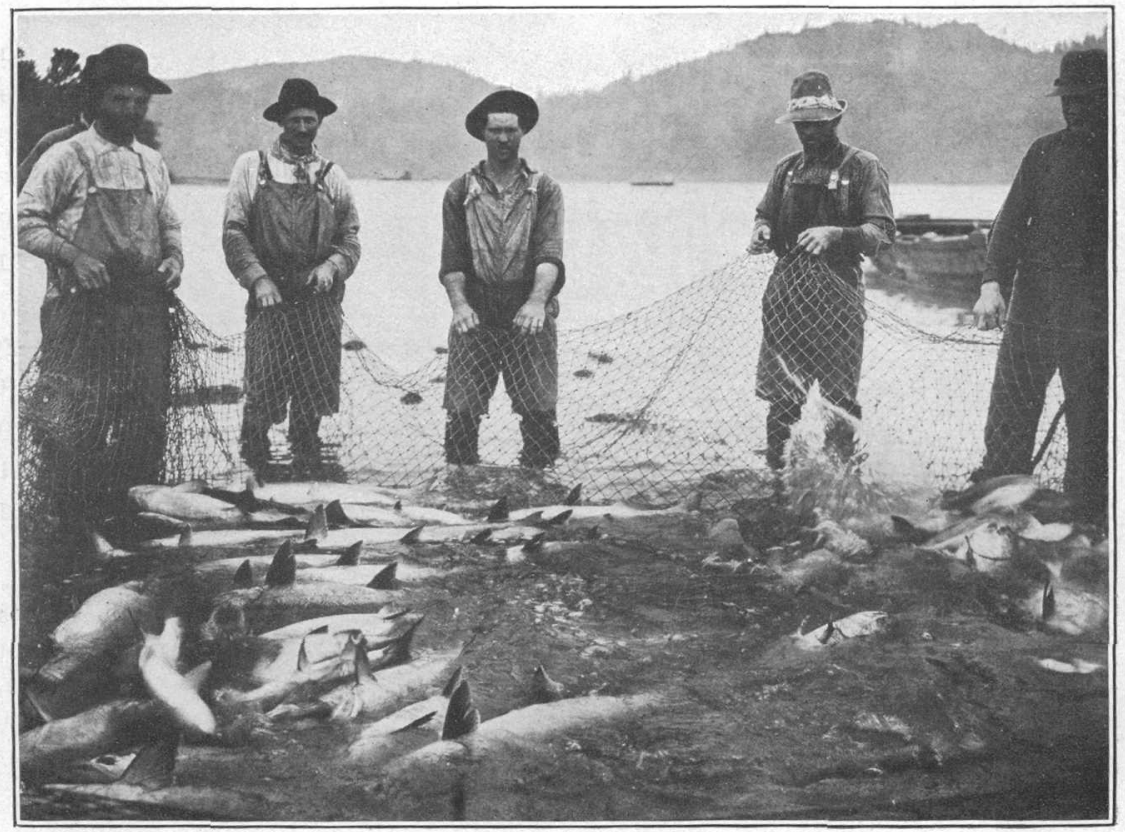

B. SEINING SALMON ON COLUMBIA RIVER. 


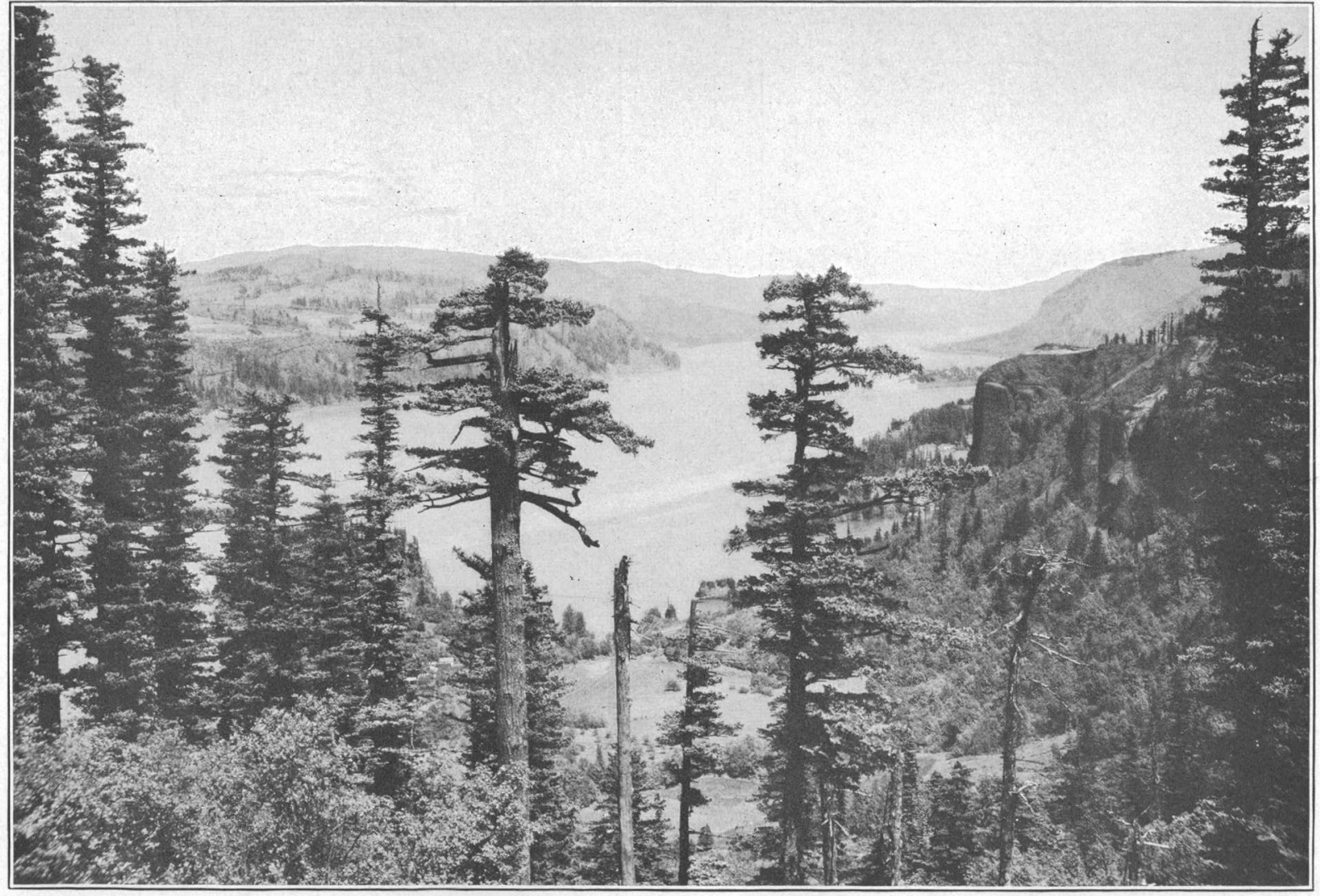

VIEW UP COLUMBIA RIVER FROM COLUMBIA HIGHWAY AT CHANTICLEER INN, ABOUT 20 MILES EAST OF PORTLAND, OREG.

On the left across the river is Cape Horn, against which the flat-topped terrace ends. This terrace, as explained on page 26, is part of the floor of a former higher Valley of the Columbia The canyon o
Portland. (See also PIs. VIII and IX.) 
Olequa Creek joins the Cowlitz, on the left, at Olequa station. Some hop fields and hop dryers are visible up the Cowlitz. On the left at the end of the bridge a bluff of columnar Olequa.

Elevation 102 feet. Population 485.* Seattle 118 miles. basalt (lava) overlies Eocene shales, and the railway passes through a deep cut in this basalt that resembles the Bergen Hill cut, near New York. At the south end of the cut, on the left, the Eocene shales are well exposed. Much of the lava of this region was probably poured out at intervals over the sea bottom while the sediments that were later consolidated into sandstones and shales were accumulating, the lava thus becoming interbedded with the coal-bearing Eocene strata. Later horizontal sheets of lava overlie the tilted coal-bearing beds near the volcano St. Helens, from which they issued, but these later lava beds, although some of them probably extend for a long distance west of the volcano, are not visible from the railway.

Toutle River is crossed near its junction with the Cowlitz, and that river, bearing numerous log rafts, may now be seen at many places on the right-hand side of the railway.

At Castle Rock frost is rare. Here are extensive farms among the low-rounded hills of the region and some small Castle Rock. orchards of prunes, cherries, and apples. The railElevation 59 feet. way cuts near Castle Rock expose 60 feet of stratified Population 998 . Seattle 125 miles. light-gray sand, forming a terrace whose top has an elevation of 120 feet above the sea.

At Ostrander (see sheet 3, p. 32) logs floated down the Cowlitz are chained into flat or cigar-shaped rafts for further transportation to the mills on the Columbia and elsewhere.

Ostrander.

Elevation 41 feet. Population 339.* Seattle 131 miles. This place is noted for the size of the timber that it can supply. A sawn stick 215 feet long can be seen by the station, and one 44 inches square and 100 feet long was prepared for the Chicago exposition.

A few miles beyond Ostrander the railway enters a 1,200-foot tunnel through a spur of basalt, from which it emerges into a broader

Kelso. part of the valley. Small stern-wheel steamers ascend

Elevation 26 feet. Population 2,039. Seattle 135 miles. the Cowlitz for 17 miles beyond Kelso. The smelt fisheries (Pl. VI, $A$ ) in the Cowlitz yield about $\$ 50,000$ annually. Canned smelts sell here at a cent a pound, and they are shipped as far east as New York.

The Cowlitz Valley contains lignite coal, and some of the seams have been worked, but the decreasing demand for coal due to the competition of California oil has put a stop to mining for the present: 
Mount Coffin, on the right, a few miles down the Columbia from the mouth of the Cowlitz, was an Indian burying ground and received its name from the large number of coffins exposed on it. On this mountain Commander Wilkes, in 1841, made astronomical observations to determine its position.

Ahead, to the right, over the flats at the mouth of the Cowlitz and beyond the Columbia, may be seen some even-crested hills about 1,000 feet in height. These continue on the southern horizon from this point to Portland Heights. Similar flat-topped hills stand also on the north side of the Columbia. If an observer so situated as to be able to overlook the whole valley of the Columbia in this region should imagine all the ravines and valleys which now separate these hills to be filled to the general level of the flat hilltops he would then see spread out before him a very broad, shallow, flat-bottomed valley and would realize that the present hills are all that is left of such a valley after its floor has been deeply furrowed and carved by streams. The hilltops are flat because they are parts of what was once such a continuous valley surface. This old broad valley was worn in basalt by Columbia River in early Pleistocene or glacial time, when the land stood 1,000 feet lower than now. When the land started to rise the streams began to cut into the old valley floor and fashioned it into the flat-topped hills of the present landscape.

At Carrolls may first be seen the cliffs of basalt

Carrolls.

Elevation 21 feet. Seattle 141 miles.

Kalama.

Elevation 21 feet. Population 816. Seattle 145 miles. which form the banks of the Columbia for hundreds of miles and attain imposing heights along the stretch of river between Portland and The Dalles.

The Northern Pacific once ferried across Columbia River from Kalama to Gobel, Oreg., and the old boat, which could carry 24 cars and an engine, can still be seen at its wharf. The railway now continues up the east side of the river to Vancouver. Seines set for salmon fishing (Pl. VI, $B$ ) may usually be seen near Kalama.

The dark bluffs on the left, which the railroad now skirts for several miles, with the river on the right, are in part solid flows of basaltic lava, but are mainly beds made up of fragments of volcanic rock associated with some sandstone and shale. At milepost 111 a deposit of sand and gravel overlies lava and shales.

As Woodland is approached a fine view opens on the left, up Lewis Valley. Mount Adams is in sight, and a little farther on, to

Woodland.

Elevation 53 feet. Population 384 . Seattle 155 miles. the forerunners of those to be seen later in Oregon and California. Helens. Finally Mount Hood comes into view to the right of Mount Adams. Near milepost 115, scattered over an alluvial bottom, are some large oaks, the left of it, appears the white cap of Mount St. 


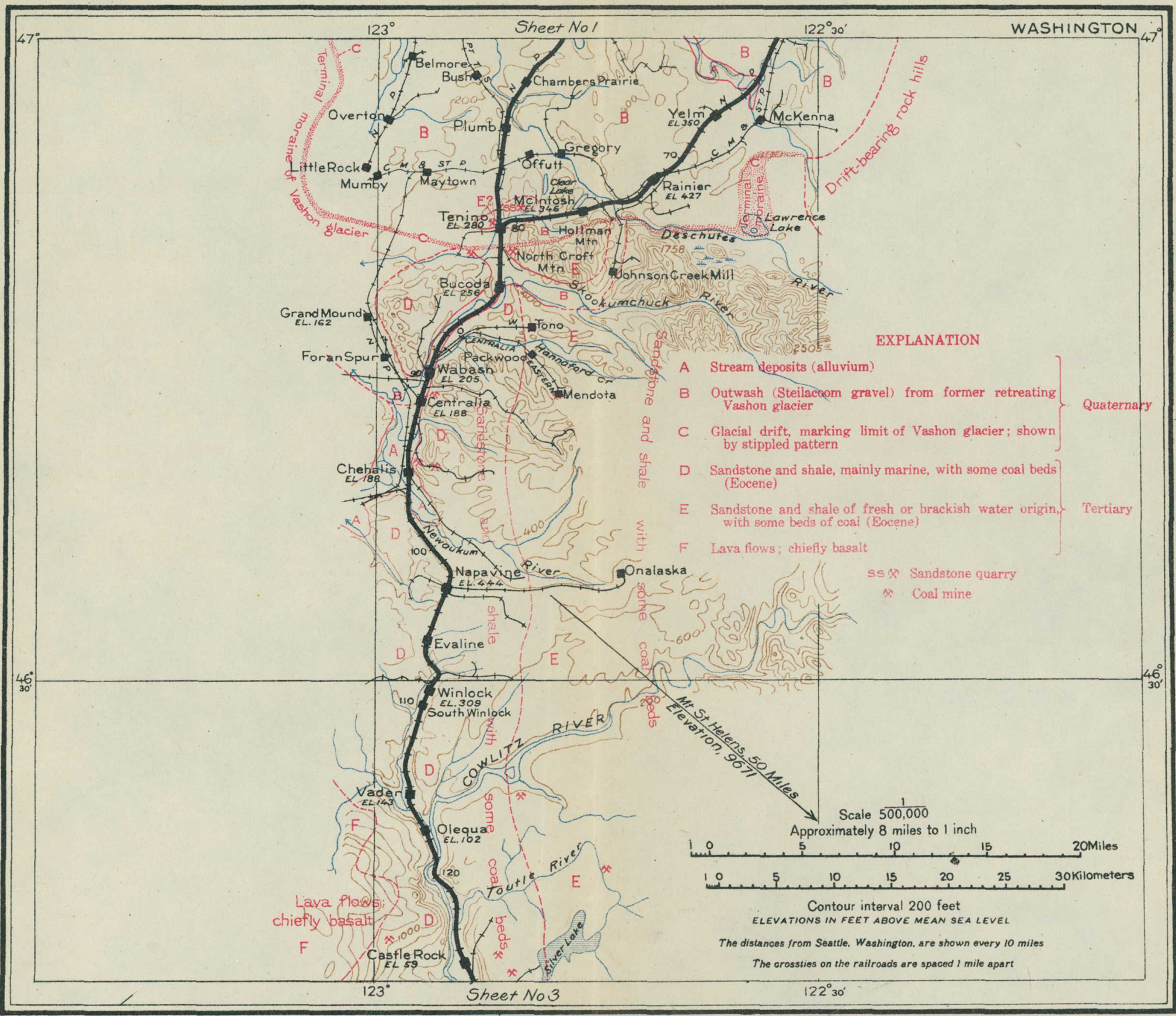




\section{GEOLOGIC AND TOPOGRAPHIC MAP}

OF THE

\section{SHASTA ROUTE}

\section{From Seattle, Washington, to San Francisco, California}

Base compiled from United States Geological Survey Atlas Sheets, from railroad alignments and profiles supplied by the Southern Pacific Company and from additional information collected with the assistance of this company

\section{UNITED STATES GEOLOGICAL SURVEY}

GEORGE OTIS SMITH, DIRECTOR
David White, Chief Geologist
R. B. Marshall, Chief Geographer

\section{5}

Each quadrangle shown on the map with a name in parenthesis in the lower left corner is mapped in detail on the U. S. G. S. Topographic . Sheet of that name. 
At 157 miles from Seattle Lewis River is crossed. The bluffs of basalt on the left here give place to slopes of gravel, sand, and clay. These deposits were laid down by Columbia River in early Pleistocene time and now form hills of pleasing rounded contours.

Two miles beyond the crossing of Lewis River are well-stratified sands and clays like those near Tacoma, and just beyond is a horizontal sheet of lava (basalt) showing the peculiar feature called columnar jointing. The columns are due to cracks produced in the lava by contraction on cooling and may be compared with the polygonal cakes into which a layer of mud breaks on drying. The mud cakes are thin in comparison with the long, regular columns found in some bodies of basalt, but the modes of formation are analogous.

Gravels deposited by the Columbia when its bed was higher than

\section{Ridgefield.}

Elevation 60 feet.

Population 297.

Seattle 161 miles.

\section{Felida.}

Elevation 61 feet. Seattle 169 miles.

\section{Vancouver Junction.}

Elevation 62 feet. Seattle 172 miles.

\section{Vancouver, Wash.}

Elevation 65 feet. Population 9,300. Seattle 176 miles. it is now occur between Ridgefield and Knapps, where they form an extensive terrace 50 feet above sea level. . On the left, near Felida, is a bluff of gravel and sand, which are older than the Pleistocene gravel of Columbia River.

At Vancouver Junction the rounded hills are covered with prune orchards. From this place a branch line runs northeastward 28 miles to Yacolt.

Vancouver is the military headquarters of the Department of the Columbia. Here Dr. John McLoughlin, the factor of the Hudson's Bay Co., who in 1824-25 ruled the region with iron hand but benevolent purpose, built Fort Vancouver, which soon became not only a thriving port for ocean vessels engaged in the western fur trade but also an outfitting point for exploring parties. In 1841 the Wilkes exploring expedition ascended the Columbia and camped at Fort Vancouver for some months, exploring the great river and its tributaries. An overland party under Lieut. Emmons, including the geologist J. D. Dana, was dispatched by way of the Willamette Valley, Mount Shasta, and Sacramento to San Francisco. In 1843 John C. Frémont visited Fort Vancouver, having floated down the Columbia from The Dalles, a route then in favor by emigrants who came into the country over the Oregon Trail. On arklike rafts loaded with farm and household belongings these emigrants glided down the river, those bound for the Puget Sound country turning northward from the Columbia at the mouth of the Cowlitz, and those for the Willamette Valley turning southward opposite Vancouver. Later, in 1853-1855, came the exploring parties of the Pacific railroad surveys in search of the best transcontinental and coast routes. 
They traversed the country from Puget Sound to the Gulf of California along the routes since followed by the Southern Pacific Co.

The Columbia ${ }^{1}$ is the great waterway from the interior of the continent through the Cascade Range to the coast. In 1805 it bore the canoes of the first transcontinental explorers, Lewis Columbia River. and Clark, from the slopes of the Rocky Mountains to the sea. Their party spent the winter on the Pacific coast and returned by the same route in 1806 .

Columbia River, including its tributaries, has a drainage area of about 259,000 square miles and a total navigable length of 2,136 miles. The system as a whole is capable of furnishing an estimated maximum of about 19,740,000 horsepower, of which only 351,249 horsepower, less than 2 per cent, was developed in 1909, the latest year for which complete statistics are available. In five States,

${ }^{1}$ Columbia River from the lower cascades to its mouth, a distance of 140 miles, is, like the Hudson, a good example of what geographers term a" drowned river." The earth's surface is not absolutely stable but is subject to upward and downward movements. As a rule these are so slow as to escape notice except in so far as their effects can be seen and interpreted by those who make a study of land forms. When a broad section of coast land traversed by a river moves downward, the sea water advances into the depressed and thereby deepened river channel, the river water is backed up, perhaps for many miles, and the lower part of the river so affected becomes a narrow inlet whose waters, instead of gliding steadily to the sea, ebb and flow with the tides.

As was explained on page 24 , the Columbia in early Pleistocene time, many thousands of years ago, flowed in a broad valley whose floor is now represented by the flat tops of the hills seen near Kalama. The land, which probably had been stationary for a long period, then began to rise. The slope of the river channel was increased, the water flowed faster, and, with the sand and bowlders of its channel as abrasives, the river began to wear down its bed. This went on until the land stood higher than at present and the river had cut its bed to a very gentle grade. Then the earth movement was reversed. The land very gradually sank and the ocean water backed up into the Columbia. It was this sinking that transformed the lower Columbia into a navigable stream, deep enough for ocean-going steamers, and made possible the commercial development of Portland and Vancouver. This is merely one of many illustrations of the direct bearing of past geologic events and processes on modern life. The influence of some of these processes, such as the formation of coal, is plain enough to all. The influence of others, though equally real, is not so obvious.

The mean range of the tide at Lower Cascades is only 0.2 foot, at Vancouver 0.8 foot, at Portland 1 foot, and at Astoria 6.4 feet. The fluctuation in the height of the river due to changes in meteorologic conditions is more than 20 feet at Portland and Vancouver, so that the tidal oscillations there are of very slight practical importance.

Rivers are the sculptors of their own valleys. The wild gorge through which the Columbia traverses the Cascade Range (Pl. VII, p. 23) is the noblest of its kind on this continent. Its history has not been fully made out, but it appears that the Cascade Range was slowly uplifted as in the form of a series of broad arches or uptilted blocks of the earth's crust along a north-south axis, and that the river, which is thought to have had nearly its 


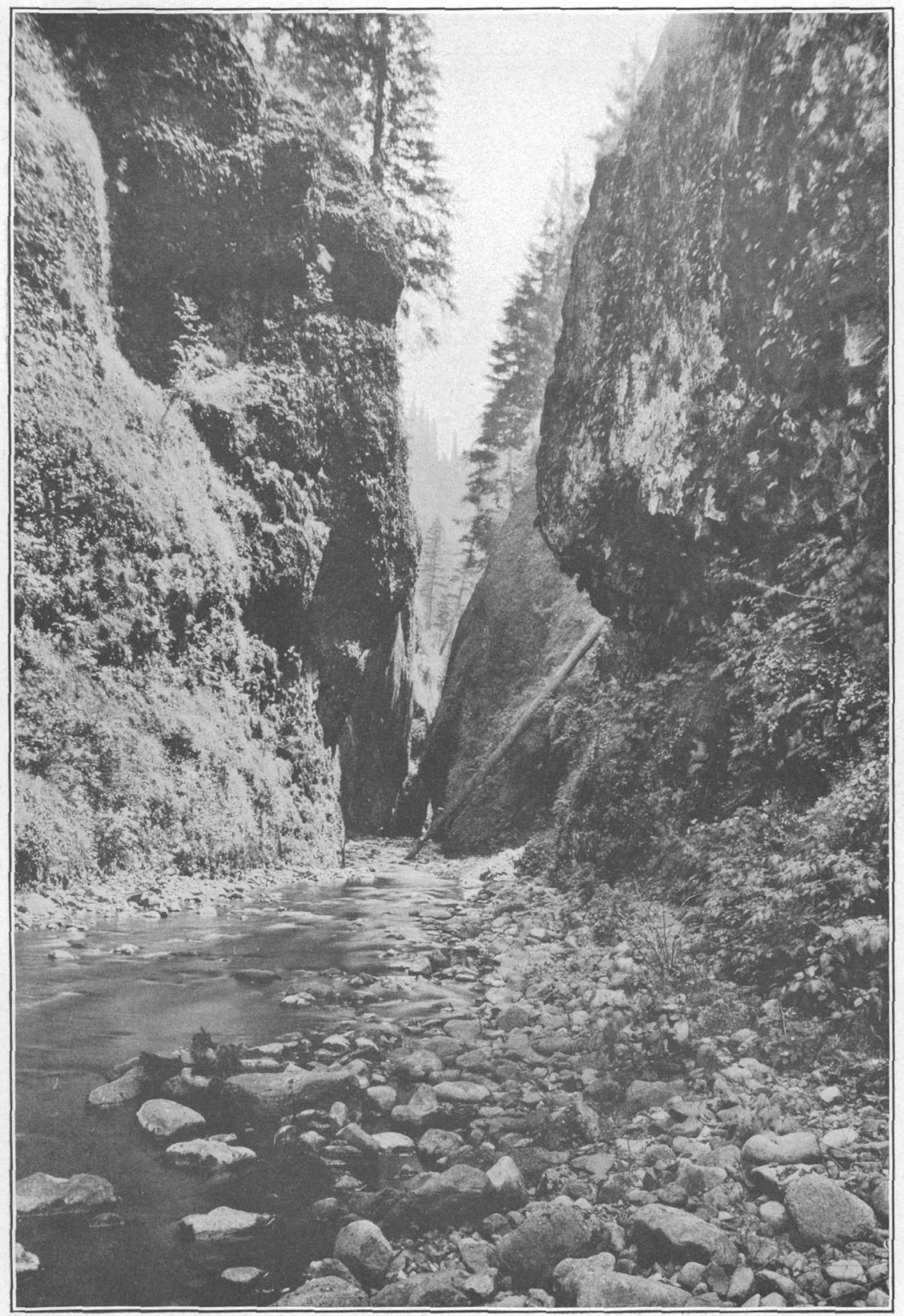

ONEONTA GORGE, COLUMBIA RIVER, NEAR ONEONTA, OREG.

The tributary stream is strong enough to cut down its bed about as rapidly as the main Columbia, making a gorge. (Compare PI. IX.) 


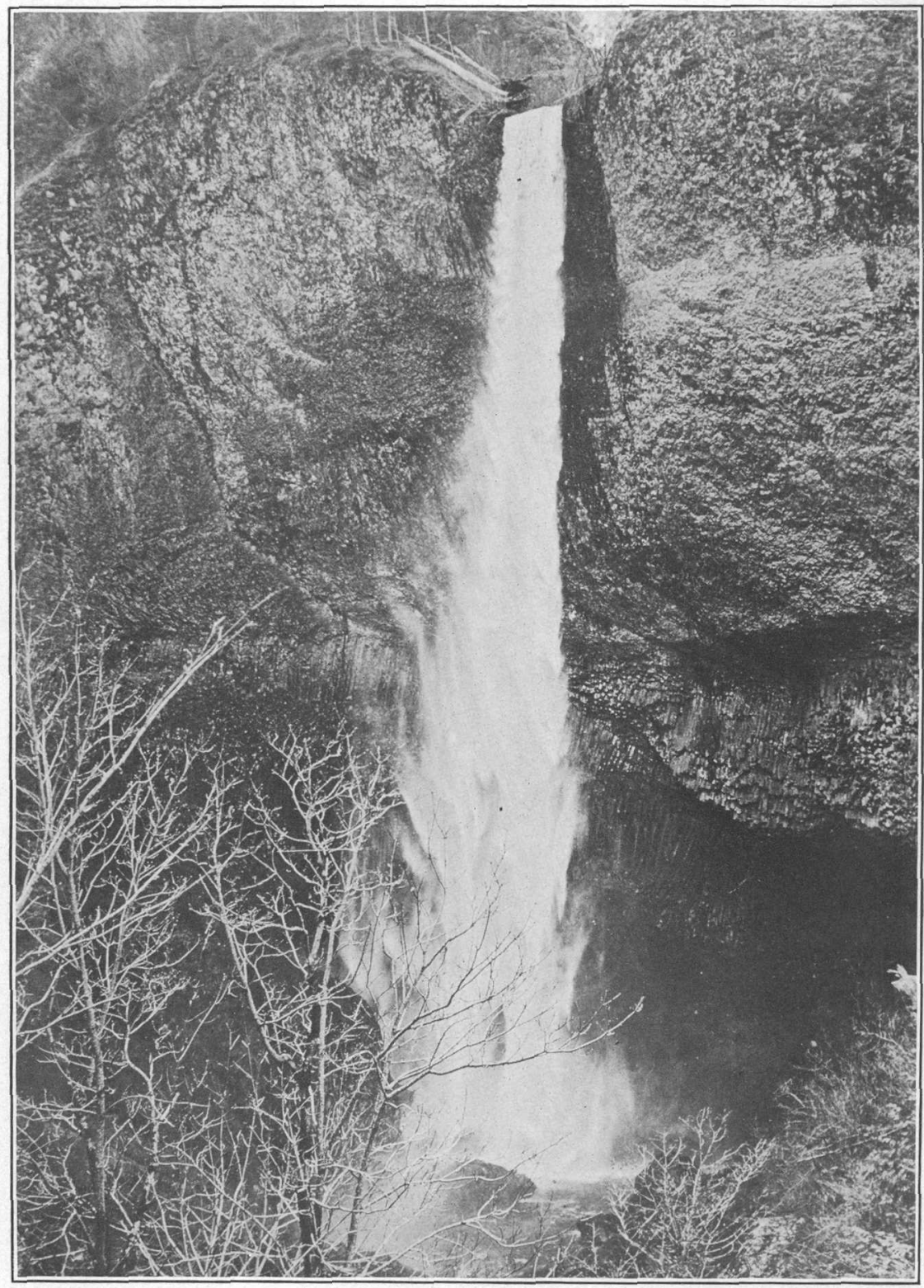

LATOURELLE FALLS, COLUMBIA RIVER, NEAR LATOURELLE, OREG.

The small tributary stream here, unable to cut down its bed as rapidly as the main Columbia, enters the river by a fall. (Compare PI. VIII.) The lava adjoining the lower part of the falls illustrates columnar structure. Photograph copyrighted by Weister. 
Oregon, Idaho, Wyoming, Montana, and Washington, 1,072 power wheels were turned by waters of streams in the Columbia River basin during that year.

The most valuable fisheries in the world, except only the oyster and herring fisheries, are those supported by the salmon. Of the salmon fisheries by far the largest are those of the Pacific coast of North America. Columbia River is justly celebrated as having afforded more salmon than any other river in the world, and Astoria is the chief center of the industry.

In early days the salmon were merely dried by the Indians. About 1833 they were first salted in old ium kegs. In 1864 the canning of salmon was begun on Sacramento River, in California, and two years later on the Columbia, where it has flourished ever since. The fish are caught in nets of various kinds, but also, and most effectively, in the salmon wheel, which may be seen at many points along the shores of the Columbia. By this device, which is kept in motion by the stream, the fish are automatically scooped up and thrown into a tank.

From Vancouver the Columbia is crossed by a new bridge more than a mile in length. The depth of the river here is 29 feet. The

present course before the range was formed, maintained its channel by wearing down its bed as rapidly on the whole as the mountains rose. The larger tributaries cut down their channels also and carved deep ravines which open on the river (Pl. VIII). The smaller streams, however, have been unable to keep pace with the main stream in lowering their channels, and reach the river by plunging over the cliffs as falls (Pl. IX). Tributary valleys perched on the sides of a main stream valley in this way are called "hanging valleys."

At Cascade Locks, in the very axis of the Cascade Range, the river has been unable to maintain a uniform grade and falls 50 feet in a series of rapids to the tidal portion of the stream. Above the cascades the river is ponded, as if the obstruction over which it falls were acting as a dam. At one time the ponding was more extensive than at present, as shown by the occurrence, some miles above the cascades, of trees belonging to species now living that have been killed by the water and partly buried in silts ( $\mathrm{Pl} . \mathrm{X}, A, \mathrm{p} .28$ ) containing their foasilized leaves.
Three explanations have been suggested for the occurrence of the obstruction at the cascades and the consequent damming of the river above them. One is that it represents a hump that has been produced across the river channel by the continued slow uplift of the Cascade Range. It is supposed, in accordance with this view, that the uplift of the range at this place has proceeded a little faster than the river could cut down its bed. Another and more probable explanation, in view of the localized character of the obstruction; is that it is due to faultingthat is, to movement along a crack in the rocks that runs approximately at right angles with the course of the river, the formation of the crack being followed by a slipping of the rocks along it in such a way that the country east of it has sunk a little or the country west of it has risen a little. A third and still more probable suggestion is that a large mass of rock has slid into the river from the cliffs and thus made a dam which has not yet been wholly washed away. Not enough geologic work has been done in the vicinity to determine which explanation is the true one. 
character and the natural sorting of the material of the river bed are well illustrated by the deposits of fine-grained sand dredged opposite Vancouver, of coarse sand opposite Russell Landing, and of gravel opposite Fishers, 9 miles above Vancouver. Halfway across the Columbia River bridge the traveler passes into the State of Oregon.

The name Oregon was in 1778 first applied by Jonathan Carver to the river now known as the Columbia and afterward somewhat vaguely to the vast country drained by it. The present Oregon. State of Oregon is about 375 miles from east to west and 200 miles from north to south and comprises an area of 96,699 square miles. Its population in 1910 was 672,765 .

Oregon, like Washington, extends across the mountain belt and includes much of the interior plateau. It has thus a wide range of climate, that of the coast being mild, equable, and humid, and that of the interior dry with pronounced variations in temperature. Most of the mountain belt is heavily timbered, and the Douglas spruce (Pseudotsuga mucronata), commonly called red fir, is said to constitute about five-sevenths of the total timber stand of the State. This tree yields the well-known "Oregon pine" of commerce. The value of the lumber and timber products of Oregon in 1912 was about $\$ 22,263,920,000$. A large part of the State lies within the great volcanic field of the Northwest, the rocks of which yield rich soils. Although great quantities of oats and barley are grown in Oregon, wheat is the principal grain crop, and most of it is raised by dry farming in the eastern part of the State. The most productive agricultural region, on the whole, is the Willamette Valley. The fisheries of Oregon are of great value. The principal product from its mines is gold, the yield in 1913 being $\$ 1,177,082$ from deep mines and $\$ 450,628$ from placers. Its water resources for power and irrigation are as yet largely unused and await the further development of the State.

Oregon was early a bone of contention between nations. While the United States claimed the drainage of the Columbia, the British were moving down from the north and Spain was advancing its missions from the south. The regulations of the Hudson's Bay Co., administered by John McLoughlin, were the first law of the region. They were superseded by a more independent form of government when Oregon was organized as a Territory in 1848. The Territory of Oregon included, besides the area of the present State, the region now included in Washington and Idaho, with parts of Wyoming and Montana. On February 14, 1859, Oregon was admitted to the Union as a State. 


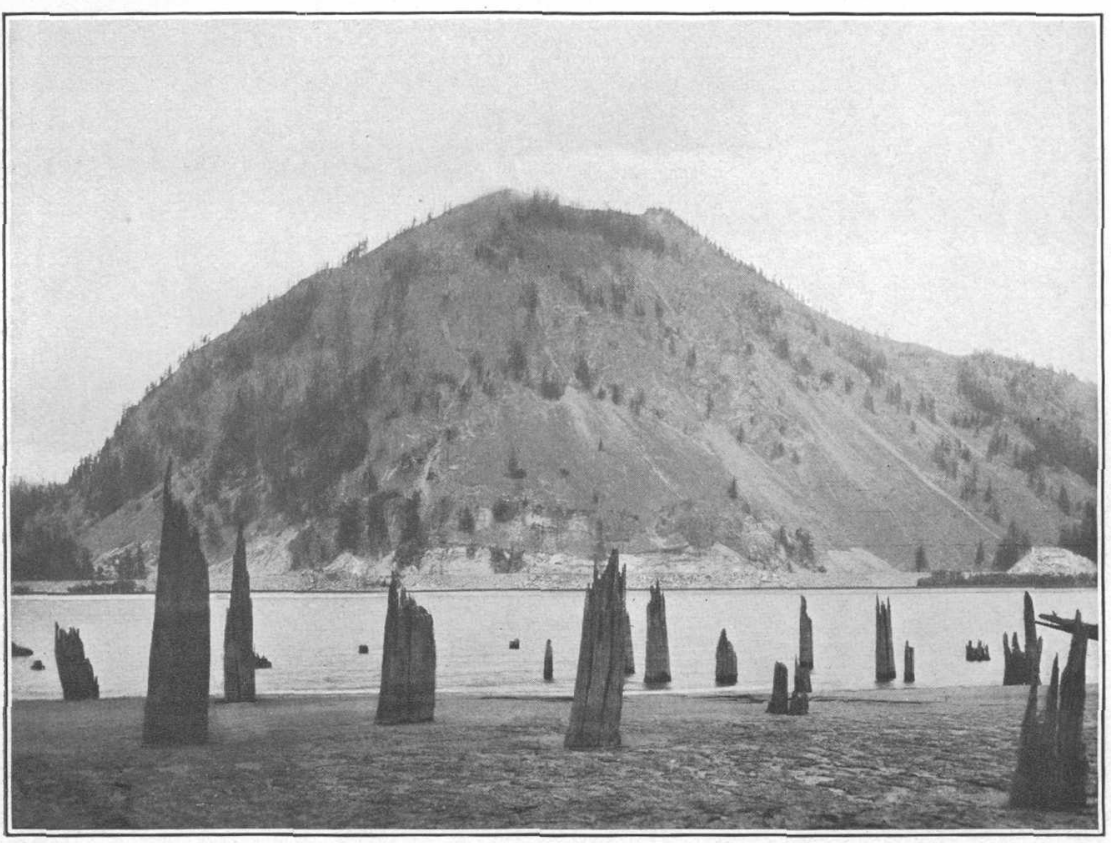

A. TRUNKS OF TREES OF A SUBMERGED FOREST, COLUMBIA RIVER ABOVE CASCADE LOCKS, OREG.

Opposite Wind Mountain, Wash. It is possible that a landslide into the river from the north side dammed back the water so as to drown the trees and cover them partly with mud.

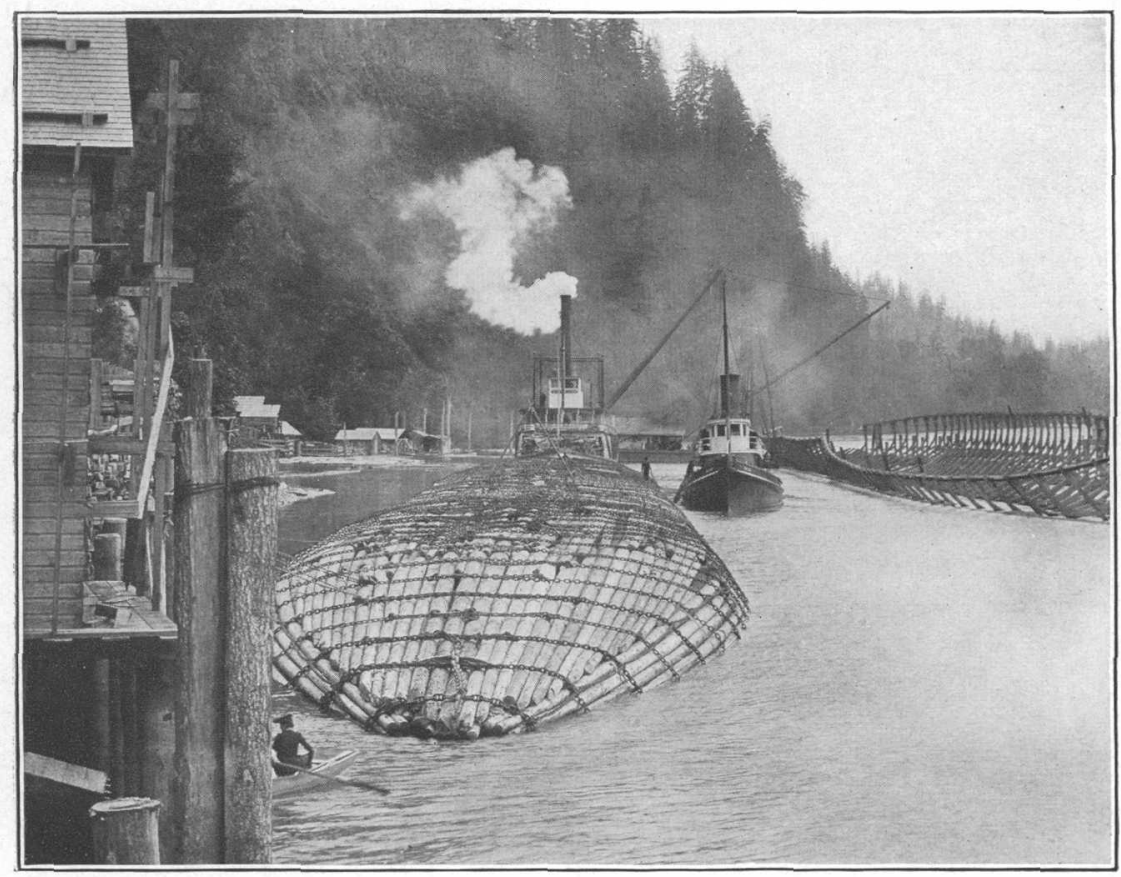

B. CIGAR-SHAPED RAFT OF LOGS FOR OCEAN TRAVEL.

On the right is the cradle in which the raft was made. 


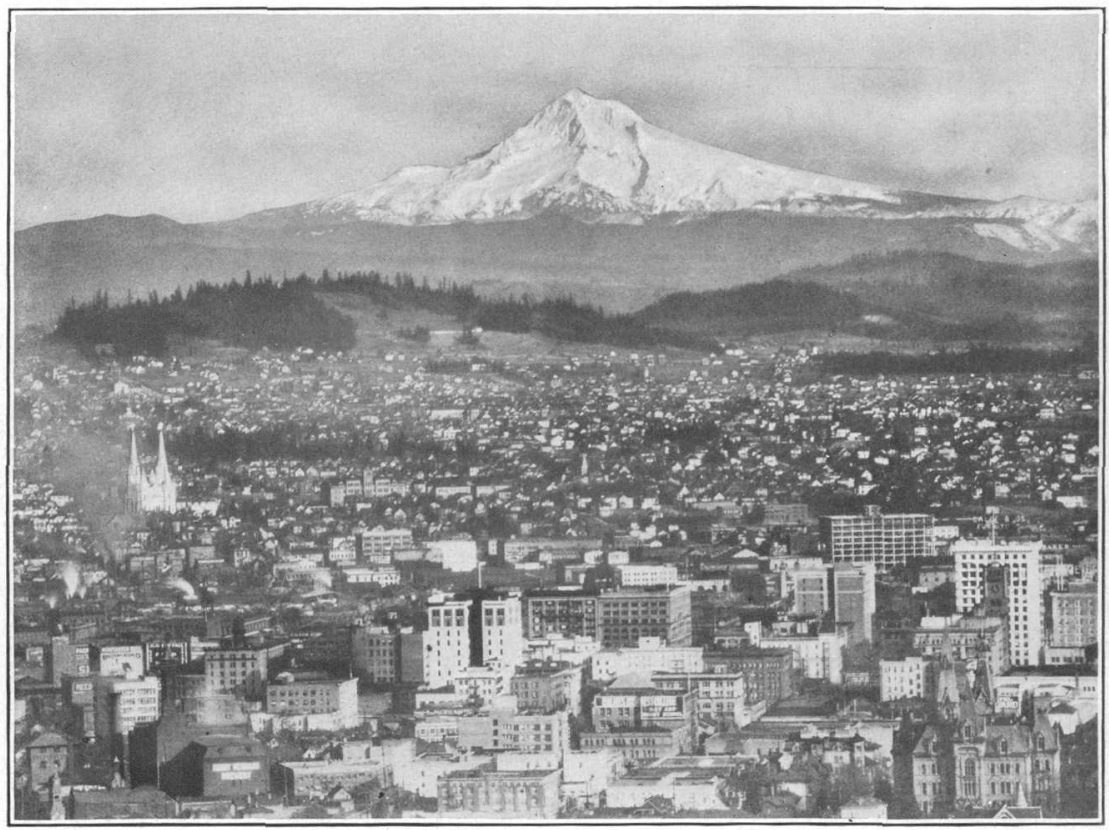

A. MOUNT HOOD FROM PORTLAND, OREG.

Photograph copyrighted by Weister Co., Portland.

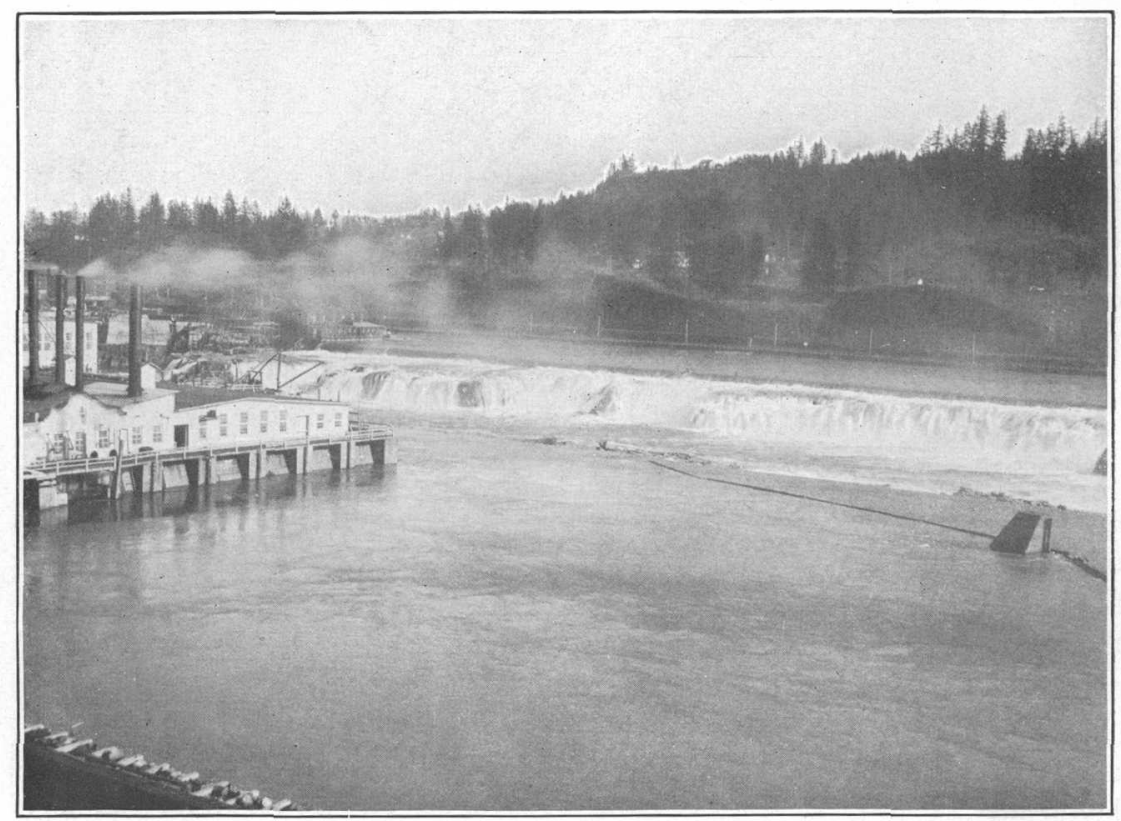

B. WILLAMETTE FALLS, OREGON CITY, OREG. 
From the Columbia the railway crosses the broad, partly swampy alluvial flood plain of the river and enters a deep cut over a mile in Columbia River to length and 30 to 100 feet deep. (See fig. 4.) This Portland. into the angle between Columbia and Willamette rivers. East Portland is built on this terrace. The principal material exposed in the cut is fine sand, rudely stratified and containing scattered lenses and streaks of gravel, with a few pebbles as much as 6 inches in diameter. In this material at intervals of 3 or

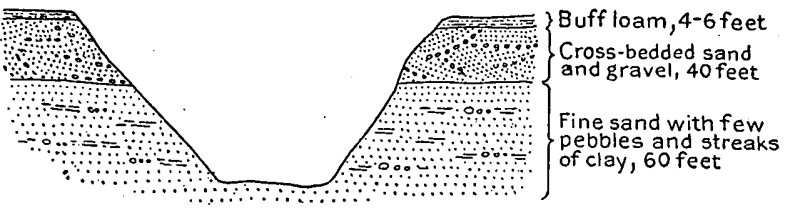

Figure 4.-Section of deep cut of Northern Pacific Railway across Portland Peninsula between Vancouver, Wash., and Portland, Oreg.

4 feet there are thin beds of clay or clay and sand. Above this lies coarse cross-bedded gray sand and gravel capped by buff loam.

Beyond the cut the railway crosses the Willamette at Willbridge and turns to the left up that stream. East of the river, above a bluff, is Columbia University (Catholic). In the bluff, which is 175 feet high, are exposed lower beds than those seen in the cut, and they include, as may be seen at one point southeast of Mocks Bottom, larger bowlders and coarse gravel. On the right as Portland is approached is Guild Lake, the site of the Lewis and Clark Exposition in 1905. It is now being filled for factory sites by washing in

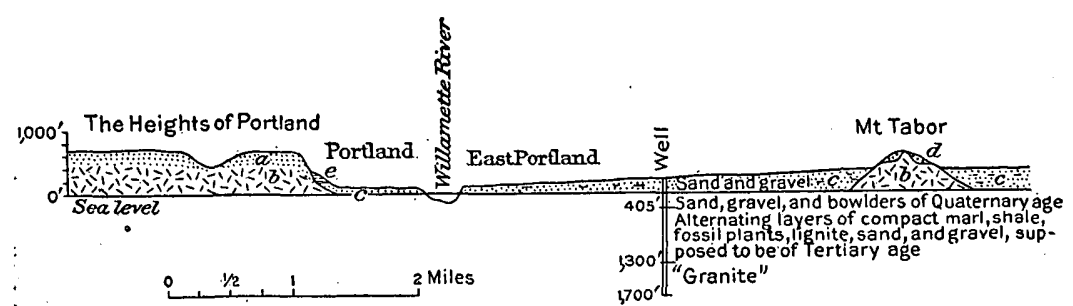

Figure 5.-East-west section of Willamette Valley at Portland, Oreg., showing the relations of the sandy loam $(a)$ and the basalt $(b)$ of Portland Heights to the sand and gravel $(c)$ on which Portland and East Portland are built and to the gravel $(d)$ of Mount Tabor and the sandy loam $(e)$ best exposed on the upper slopes of Westover Terrace.

gravel. Across the lake is a dark bluff, which is notched by the ravines of small streams that drain a plateau west of it. The bluff, which is made up of basalt lava, is capped by buff sandy loam that has resulted from the weathering of the basalt. A diagrammatic section from the plateau on the west, through the river terraces on which the cities of Portland and East Portland are built, to Mount Tabor on the east is shown in figure 5 .

The flat-topped heights west of Portland, including Council Crest, are part of what in early Pleistocene time was an extensive nearly level surface produced by erosion-a peneplain, as it is termed by 
geologists. As such a surface is not produced until the region is worn down nearly to sea level, this plain must have been elevated since it was formed. Remnants of this old surface, ${ }^{1}$ which has been deeply cut by the present rivers and their tributaries, extend up the Columbia to Cape Horn and up the Willamette to a point beyond Oregon City.

Portland, 186 miles south of Seattle and 771 miles north of San Francisco, is often referred to as the Rose City on account of the beauty and profusion of the queen of flowers Portland, Oreg. in its gardens and even along its streets. An annual

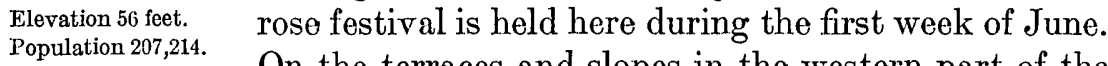
Seattle 186 miles.

On the terraces and slopes in the western part of the city, which have a range of altitude of more than 1,000 feet, there are many beautiful homes, each with its garden, from which may be obtained views that are surpassed in few other cities in the world-such as the view across the Willamette to the snow-crowned peaks of Mounts St. Helens, Adams, and Hood (Pl. XI, $A$ ).

The settlement was founded in 1845 by two men from New England and was named after Portland, Maine. It was chartered as a city in 1851. Its situation at the head of deep-water navigation on the Columbia and Willamette and at the gateway for railroads to the East through the gorge of the Columbia gives it great advantage as a commercial center. Steamships ply from it to many domestic and foreign ports. It exports every year raw materials and foodstuffschiefly wheat, wool, lumber, fish, and flour-to the value of over $\$ 15,000,000$, and its manufactured products, including woolen goods, flour, and many other articles, amount to $\$ 35,000,000$ annually.

1 This peneplain is related to a similar one in central Washington and to an elevated beach along the coast of Oregon which records the ocean level at that time. It was in the later stages of this period of erosion that the basalt became so deeply weathered.

The general uplift of the region that followed the formation of this peneplain caused the rivers to cut deep, wide valleys across it and expose the lava and underlying Tertiary sediments in bluffs such as those near Portland. Subsidence followed and the valleys were partly filled with gravel. A succeeding uplift enabled the rivers to carry away much of this old gravel in the Columbia Valley, but a remnant of it may be seen on Mount Tabor, a basalt knob in East Portland. The knob is itself a remnant of an ex- tensive lava flow. Still another subsidence caused the rivers to deposit the gravels and sands of the terrace on which Portland and East Portland are built. These sands and gravels were themselves cut into and trenched in consequence of a later moderate uplift of the land. Finally, as has been seen, a relatively slight depression drowned the lower reaches of the Columbia and, of course, of the Willamette also. It thus appears that the land in this region has had many ups and downs in late geologic time. The movements here noted, however, are only the more conspicuous ones. Many minor oscillations have left less noticeable traces in the landscape. All these movements were probably so slow that they passed unnoticed by men if any were there at that time. 
Among the more notable buildings are the Public Library, the Wells Fargo Co.'s building, the Chamber of Commerce, the Commercial Club, the Oregonian Building, and the Art Museum. Of the church buildings, the Presbyterian, Congregational, Baptist (White Temple), and Episcopal (Cathedral) should be mentioned. The City Hall contains the Oregon Historical Society's museum and the Hawkins Museum of Natural History.

Willamette River, which separates East Portland from Portland, is spanned by five bridges.

Electric cars afford easy access to the hilltop known as Council Crest, from which superb views may be had of the rolling lava plateau in which the Willamette has cut its valley, a country Excursions from of rich farms and orchards. To the east may be seen Portland.

the Cascade Range, surmounted by ihe lofty peaks of Mounts Rainier, St. Helens, Adams, Hood, and Jefferson.

Cloud Cap Inn may be reached in a day by the Oregon-Washington Railroad \& Navigation Co.'s train up the south bank of the Columbia to Hood River station, thence by auto stage through the famous orchard country of the Hood River valley and up the northern slopes of Mount Hood to an altitude of nearly 6,000 feet. From this place the glaciers are in full view and may be easily reached. The cliffs along the south side of the Columbia (Pls. VII-IX), seen on this trip, are remarkable for their sheerness and for the numerous waterfalls that plunge over them to the river, but the cliffs upon the north side of the river are in general less imposing and lack falls. Fish wheels, log rafts for ocean transportation (Pl. X, B, p. 28), and the Cascade Locks are additional attractions of a trip that is well worth taking.

Astoria, near the mouth of the Columbia, may be reached by steamer or railway. The river is 5 miles wide here. At its mouth are the great Government jetty; Forts Stevens and Scarboro Head, which guard the entrance; lighthouses; and a life-saving station. Some typical sand dunes may be seen near Astoria, and the type locality for the rocks and fossils of the Astoria shale (Oligocene) is in this vicinity. Here, many years ago, Prof. J. D. Dana, then on the Wilkes expedition, observed some sandstone dikes, formed by sand that filled wide cracks in the rocks and later itself hardened into rock. As a rule dikes are composed of igneous rock which has been forced into such cracks in a molten condition. Dikes of sandstone are comparatively rare.

John Jacob Astor founded the town of Astoria in 1811 as a depot for the fur trade. It was seized by the British in 1813 but was restored in 1818. In 1821, while occupied by the Northwest Fur Co., it was burned and practically abandoned, the Hudson's Bay Co. being left in control of the country. 
Trains from Portland by the Spokane, Portland \& Seattle Railway connect with steamers of the Great Northern Pacific Steamship Co., which run to San Francisco three times a week.

On leaving Portland for the south the railway crosses Willamette. River and ascends its valley. The drainage basin of the Willamette is a roughly rectangular trough-shaped hollow, 145 Willamette River. miles long and 80 miles wide, lying between the Cascade and Coast ranges. Its area is over 11,000 square miles. The maximum power available from the river and its tributaries is 1,670,000 horsepower, of which 92,537 horsepower had been developed in 1909, the date of the United States Census report. The river is navigs ble for 100 miles, and shallow-draft steamers ply regularly from Portland to Oregon City, Dayton, and Corvallis.

East Morrison Street station is in the manufacturing suburb of East Portland, and a mile beyond, on the left, is the new Ford automobile factory. Half a mile beyond the suburb of Brooklyn, near milepost 767 from San Francisco, on the left, there are gravel terraces, on which stand the buildings of Reed College. For miles the railroad runs through a beautiful fertile country in which cultivated fields are interspersed with groves of firs, alders, and other trees. The white-flowered arrowwood, purple hardhack, and fireweed beautify the hedges and fields. Along this part of the route there are fine views of the even-crested bluff, probably of basalt, that bounds the valley of Kellogg Creek on the west. The smooth soil-covered slopes over which the train passes end abruptly against this bluff, which is probably due to a fault. Near Milwaukie (milepost 762), on the left, is Harmony School, and beyond are Mount Scott and other prominent rounded hills of lava (basalt).

There appears on the left, just before the train reaches Clackamas (see sheet 4, p. 36) a small sulphurous-looking factory where spray compounds for fruit trees are made. The State Rifle Range is near Clackamas. Opposite the station there is a fine

\section{Clackamas.}

Elevation 137 feet. Population 730.

Seattle 197 miles.

\section{view of Mount Hood over field and forest.}

Near milepost 758 the railroad crosses Clackamas River, which is bordered by banks of basalt. On the south side is Park Place station near Gladstone Park.

As Oregon City is approached the valley of the Willamette narrows to a canyon between bluffs of basalt.

Oregon City, situated at the Falls of the Willamette (Pl. XI, $B$, p. 29), is a manufacturing town and produces paper and woolen goods. The water here falls 40 feet over basalt

Oregon City.

Elevation 102 feet. Population 4,287. Seattle 201 miles. to tidewater level. A large hydroelectric plant by the falls supplies light and power for Portland, and the maximum available energy is said to be 50,000 horsepower. A lock canal along the west bank of the river transfers steamers and other boats past the falls. 


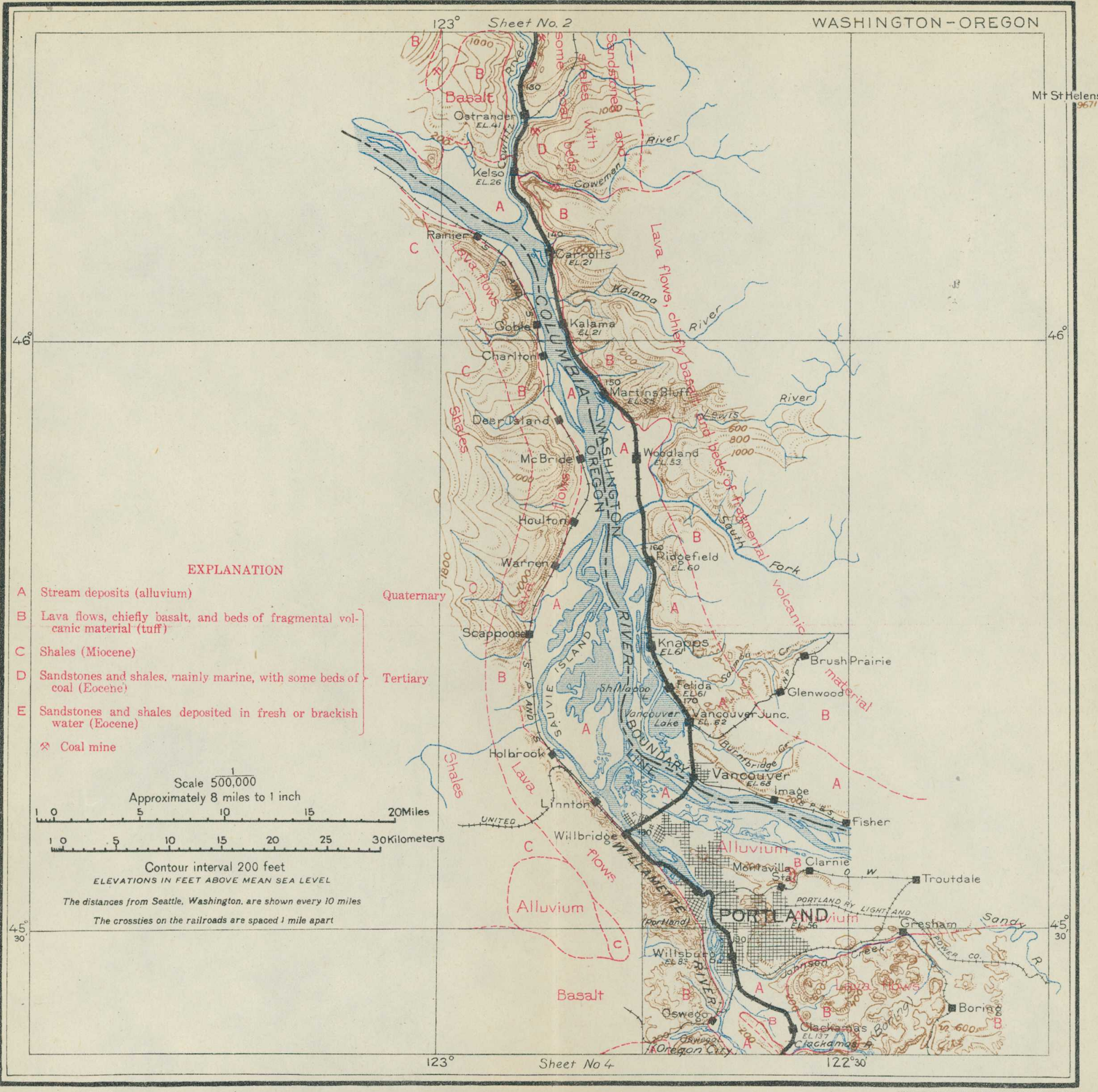




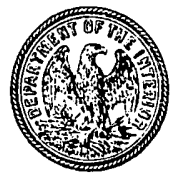

\section{GEOLOGIC AND TOPOGRAPHIC MAP} OF THE

\section{SHASTA ROUTE}

\section{From Seattle, Washington, to San Francisco, California}

Base compiled from United States Geological Survey Atlas Sheets, from railroad alignments and profiles supplied by the Southern Pacific Company and from additional information collected with the assistance of this company

\section{UNITED STATES GEOLOGICAL SURVEY}

GEORGE OTIS SMITH, DIRECTOR
David White, Chief Geologist
R. B. Marshall, Chief Geographer

1915

Each quadrangle shown on the map with a name in parenthesis in the lower left corner is mapped in detail on the U. S. G. S. Topographic Sheet of that name. 
Basalt bluffs restrict the outlook from the train, but the accompanying section (fig. 6) shows what may be seen above the bluff on the left (east), near the quarry and crusher, and along the road to Ely.

Dr. John McLoughlin, the Hudson's Bay Co. factor, settled here and did much for the early settlers and afterward for the town. His house is carefully preserved in a park that commands a fine view of the river.

Between Oregon City and New Era, a distance of 6 miles, the Willamette has cut a canyon 450 feet in depth across an extensive rolling upland on which are many fine farms. This upland is traversed by the Pacific Highway, a road from San Diego, Cal., to Vancouver, British Columbia. Along the sides of the canyon, at elevations of 100 to 200 feet above the sea, are remnants of a well-defined terrace. These are parts of a former bottom of the canyon, made when the river was flowing at a higher level. The upland is an old erosion surface, and was formed, together with the canyon and the terrace (fig. 6), while the gorge of the Columbia was being cut, before the falls at Oregon City came into existence. The falls have sincé cut back about a mile from their first position. In comparison with the recession of some falls-for example, Niagara, which has receded

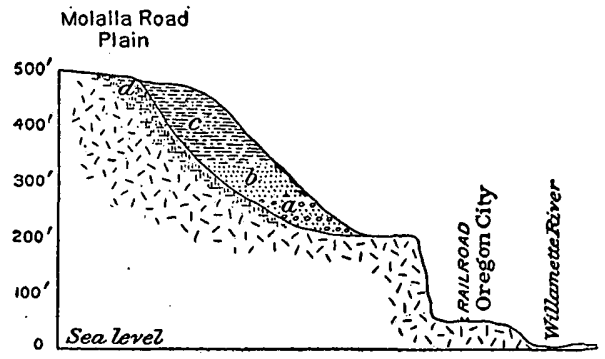

Figure 6.-Section of east bluff at Oregon City, Oreg. $a$, Stratified gravel and sand; $b$, stratified coarse sand; $c$, stratified fine loamy material; $d$, decomposed basalt resembling material of $c$. These materials are like those noted at Westover Terrace, Portland. They are well exposed near the quarry at the head of Munroe Street, Oregon City, and on the Molalla road to Ely. about 9 miles-this distance is not great, but the rock is hard and gives way slowly under the wearing action of the water.

Near Coalca, at milepost 751, on the left, scarcely visible among the trees of the terrace above the train, is Coalca or Balanced Rock, which marks the scene of many an Indian council.

At New Era the railroad emerges from the canyon into a broad alluvial valley deeply filled with unconsolidated material deposited

New Era.

Elevation 162 feet. Seattle 207 miles. Fishs Eddy the river impinges from the west against bluffs of lava,

1 The explanation of the fact that the Willamette between Oregon City and. New Era flows through a canyon, while north of Oregon City and south of New Era it occupies broad valleys, is thought to be as follows: At a time not definitely determined but probably early in the Pleistocene epoch a fracture was formed in the basaltic rocks near the site of Oregon City. This fracture had a general 
which cause it to turn abruptly northwestward. At this place may be seen some Pleistocene sediments, deposited in the valley probably while the river was temporarily dammed, as described in the footnote.

From this point to Salem the railroad passes through a region of broad alluvial plains with prosperous farms won from the great forest, which is represented now only by stumps and by scattered groups of tall firs.

The Clackamas County Fairground is visible on the right as the train enters Canby. Half a mile beyond the town is a railroad gravel pit. The gravels have the characteristic delta

Canby.

Elevation 179 feet. Population 587. Seattle 210 miles. structure, known as cross-bedding-a series of layers all inclined in one direction capped by nearly horizontal layers. They resemble the delta deposits seen near Puget Sound. Southeast of Canby, near Wilhoit, is a farm where teazels are grown. The dry thistle-like head of the teazel is used by fullers to comb up the nap on woolen cloth, and this farm is said to furnish a large part of the world's supply. At milepost 746 the railroad crosses Molalla River, which here flows along the east side of its broad, flat valley. In this valley are grown wheat, oats, potatoes, peaches, apples, and hops. In the neighborhood of Barlow and Aurora, where Pudding River is crossed, the forested areas increase, but to the northwest, near Newburg, there is a fine orchard country. (See Pl. XII.)

At Hubbard and between Hubbard and Woodburn

Hubbard.

Elevation 210 feet. Population 283.

Seattle 218 miles.

\section{Woodburn.}

Elevation 210 feet. Population 1,616. Seattle 222 miles. the country is open to the east, and the traveler may get views of the Cascade Range, with Mount Jefferson and other snow-covered summits. Woodburn is the center of a rich farming country. Beyond the station a vista opens on the right to the Coast Range. Rural scenes continue to Gervais, a town notable for its fresh, white cleanliness. About a northwesterly course. The rocks on opposite sides of it began to move, and apparently the principal movement was a rise of the rocks on the southwest side. The rocks were lifted as a tilted block, the hinge of the movement being somewhere near the site of New Era. The tendency of this movement was to dam the Willamette above New Era. Temporarily the river may have been ponded back, but on the whole it appears to have been able to cut a canyon in the basalt as fast as the rock rose. The Tualatin, a tributary which formerly entered the Willamette at Oswego, 5 miles below Oregon City, also had its course across the rising block of lava, but being a less powerful stream than the Willamette, it was unable to maintain its original channel. It was forced to flow southeast, along the sloping back of the uptilted block, and now enters the Willamette nearly 3 miles above Oregon City. Oswego Lake, a long, narrow body of water trending at right angles to the Willamette west of Oswego, is really a remnant of the former lower part of the Tualatin.

While the Willamette was engaged in cutting the canyon through the hard lava block it had time to swing from side to side above the obstruction and to erode from the softer rocks the wide valley which the traveler sees as he emerges from the canyon. 


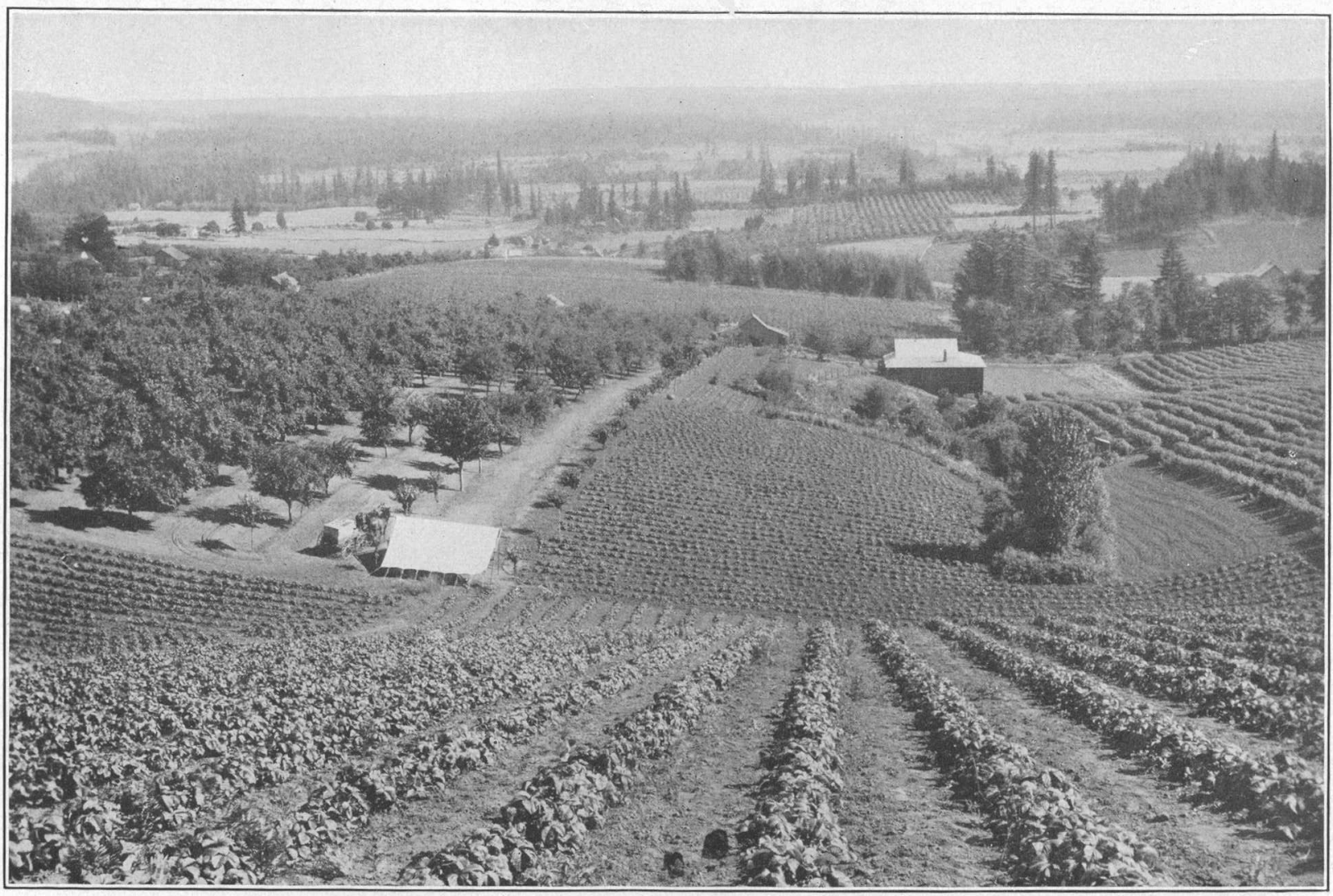

WILLAMETTE VALLEY NEAR NEWBURG, NORTHWEST OF HUBBARD, OREG. 


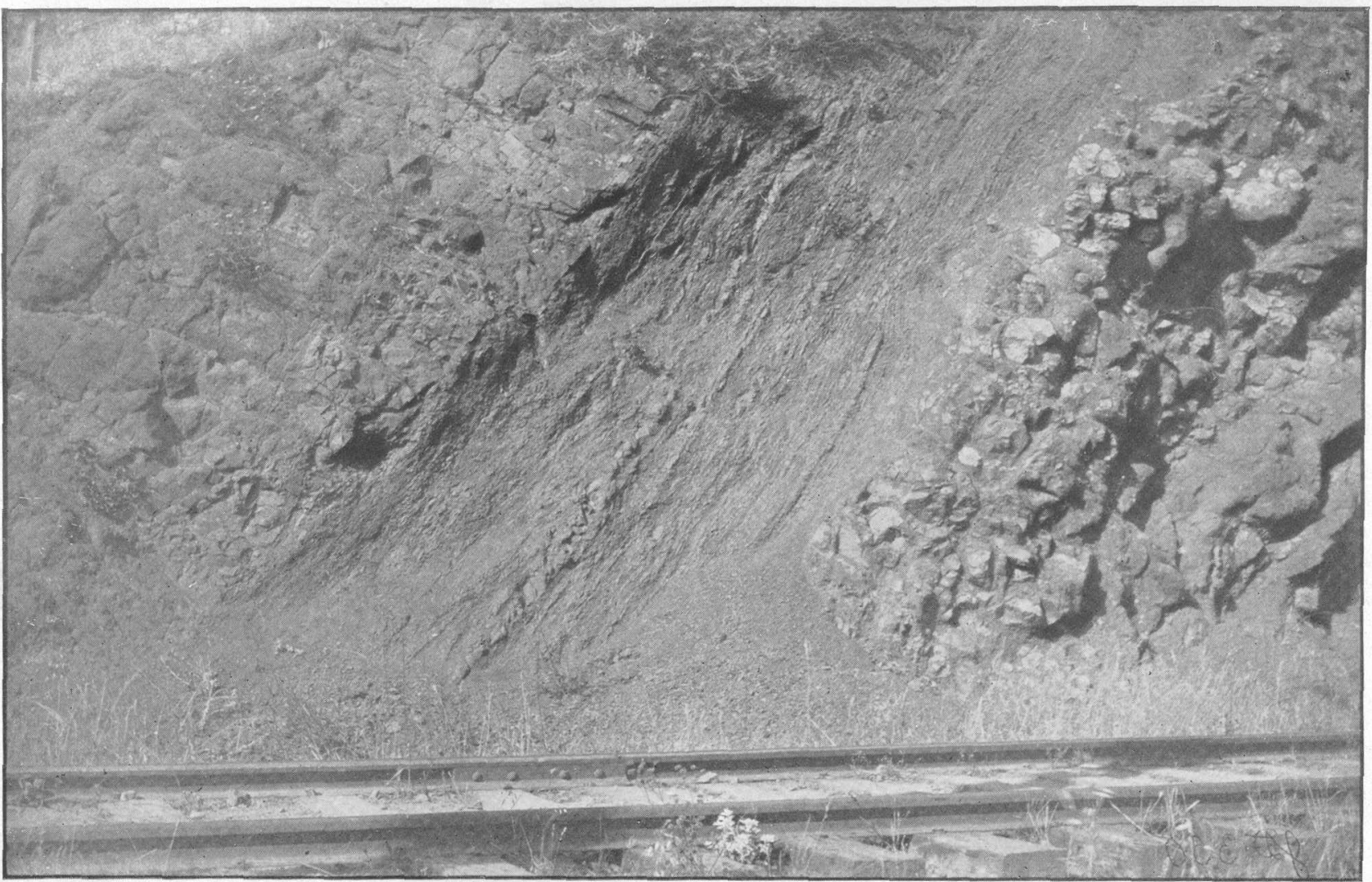


mile beyond Gervais patches of blue toadflax (Linaria canadensis) may be seen in the fields in June. Less than a Gervais.

Elevation 212 feet. Population 276.

Seattle 225 miles.

\section{Brooks.}

Elevation 230 feet. Population 1,018.* Seattle 230 miles. mile farther on, at the right, is a grove of oaks which contrast with the more common fir.

Just north of the town of Brooks is a noted loganberry farm, and during the season the adjacent oak woods are white with the tents of the berry pickers. The loganberry is a hybrid produced by crossing a red raspberry with a species of blackberry. It was named for its originator, Judge Logan, of California.

At Chemawa is an Indian school with good buildings and wellkept grounds. It has about 600 students and teaches in a practical way many trades and industries, giving most atten-

Chemawa.

Elevation 188 feet. Population 2,043.* Seattle 233 miles. tion to agriculture. The results are well illustrated on the school farm. Prune, apple, and cherry orchards and berry gardens become more numerous as Salem, the State capital, is approached.

Salem is beautifully situated on Willamette River amid rolling hills that yield abundantly all kinds of farm, orchard, and garden products. It is in one of the most productive cherry

Salem.

Elevation 191 feet. Population 14,094. Seattle 239 miles. districts of the State, and its cherry festival is an annual attraction. Salem is noted also as a hop and prune center. The State buildings are near the railroad on the righ ${ }^{2}$, and close to them are those of Willamette University. The State asylum for the insane and the penitentiary, surrounded by beautiful grounds, are about a mile from the railroad on the left.

A short distance west of Salem are some hills of basalt that are outliers of the great masses of volcanic rocks forming the Cascade Range. A pleasant trip on the Salem Heights electric car, running a mile to the south, will enable the traveler to see the lavas at many points and to obtain an excellent view of the city among its trees.

On leaving Salem for the south the railroad follows the valley of - Mill Creek to Turner. The basalt hills just mentioned are on the right. Two miles from Salem, on the same side, is the Asylum for the Feeble Minded. On the left is the broad alluvial valley of Mill Creek, and a few miles farther along the State Industrial Training School for Boys, which stands on a hill that appears to be basaltic. Where the railroad rounds the basalt.slopes on the right the brightyellow monkey flower (Mimulus) borders the track in June, and at that season there is a wealth of flowers on every hand. The goldenrod (Solidago) appears even as early as the end of June, and among the small trees is the attractive madrona (Arbutus menziesii), with its brown bark and fresh, glossy evergreen leaves. 
For miles south of Turner the Cascade Range is in view on the left (east). Mount Jefferson and the Three Sisters can be seen if the Turner.

Elevation 332 feet. Population 191.

Seattle 246 miles. weather is clear. On the right, a few miles away, are basalt hills, some densely forested with firs but others cultivated. The varicolored crops make a beautiful contrast with the forest.

Here, through spring and summer, the exultant song of the western meadow lark is heard, and bob white, the eastern quail who has been brought west, expresses contentment in his new quarters. Here, too, in the early hours of the day the traveler will hear the rippling music of the Chinese pheasant and will not wonder that

Marion.

Elevation 329 feet. Population 564.* Seattle 253 miles.

Rostand's Chantecler, listening to that melody, forgot to give his clarion call that was to set the world going for another day.

Marion is surrounded by a great hay country in which, as elsewhere in Oregon, vetch is grown with wheat and oats for hay, with excellent results.

At Jefferson the railroad crosses Santiam River, one Jefferson.

Elevation 268 feet. Population 415.* Seattle 257 miles.

of the largest tributaries of the Willamette. Under the bridge at low water can be seen dark, more or less carbonaceous shales. The railroad passes between hills of basalt and traverses the alluvial plain past Millersburg to Albany.

Albany, which is on the Willamette at the mouth of Calapooya River, is an important railroad center. Branches from the main line of the Southern Pacific extend from it to the

Albany.

Elevation 240 feet. Population 4,275. Seattle 266 miles. coast on the west and into the Cascade Range on the east. ${ }^{1}$ A short distance south of Albany the Cascade and Coast ranges are in full view. Both ranges have been so eroded as to present irregular sky lines. Marys Peak dominates this part of the Coast Range, and some basalt buttes between Santiam and McKenzie rivers are outliers of the Cascade Range.

${ }_{1}^{1}$ Trips over these branches give the traveler interested in geology and in the relations of mountains to valleys an opportunity to study a partial cross section of the Pacific System, including the Oregon Coast Range, the Willamette Valley, and part of the Cascade Range.

At Corvallis, on the way to the coast, is the Oregon Agricultural College, a State institution with which is connected a Federal agricultural experiment station. Here also are the headquarters of the Oregon Bureau of Mines and Geology. There were 28 graduate and 1,250 undergraduate students at the college in 1913 . Sand- stones of Eocene age form the foothills west of the Willamette Valley and fossils belonging to that epoch occur near Corvallis. The crest of the Coast Range is composed of Astoria shale (Oligocene), but farther west; at Yaquina Bay, where the branch railroad ends, Miocene and Pleistocene fossils are abundant.

The Corvallis \& Eastern Railroad, a branch of the Southern Pacific running east from Albany, follows up Santiam River, passes some sharp basalt buttes in the valley, and apparently crosses a belt of Eocene strata before reaching the lavas of the Cascade Range. 


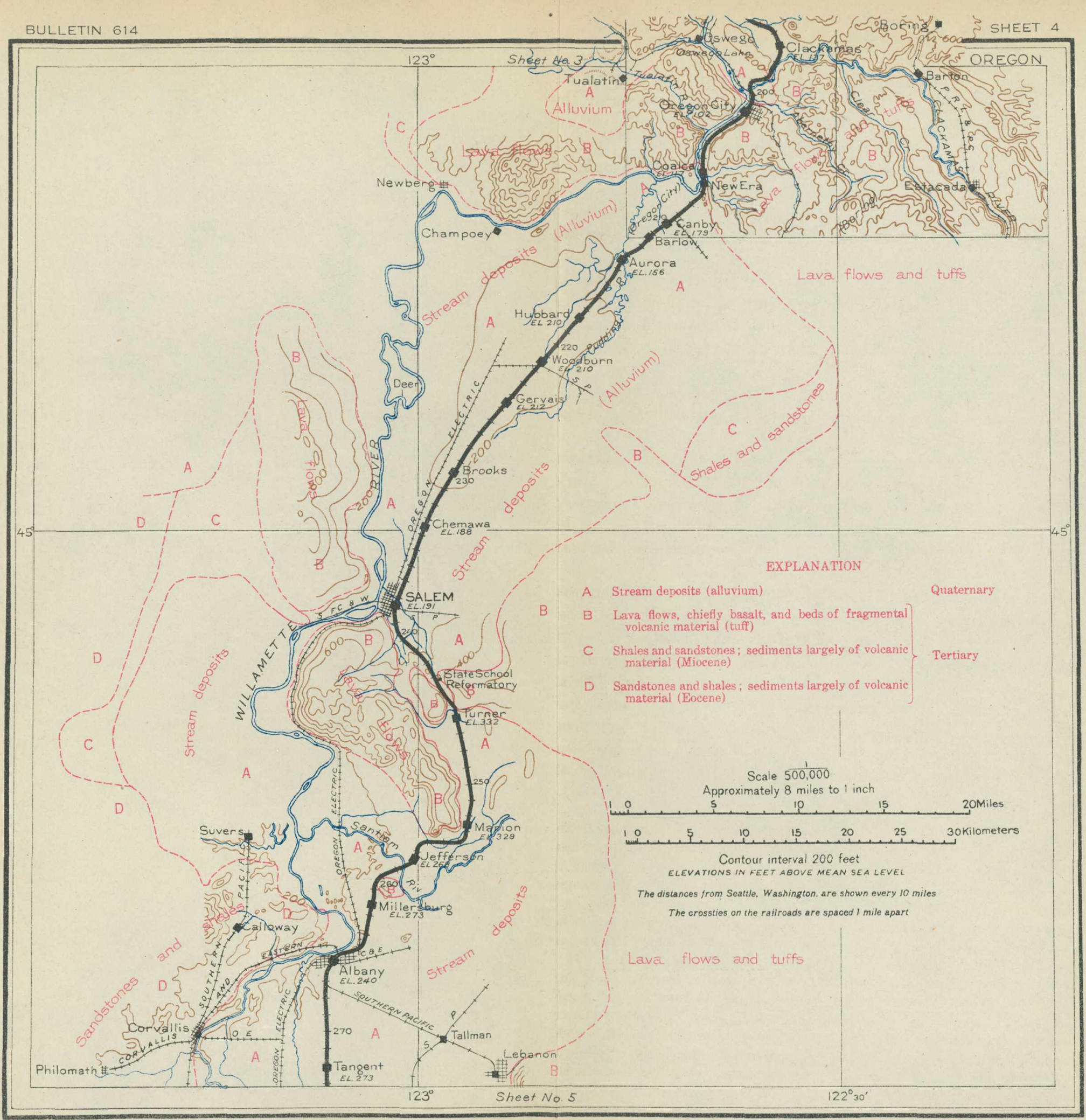


For 19 miles south of Albany the railroad runs through a highly productive grain and hay country. Oats and wheat are the principal grains produced and clover is grown, chiefly for seed. Vetch is sown with grain to some extent to make hay, but most of the hay crop is made from native grasses, which are cured and baled for market. From Albany Junction to a point a few miles south of Halsey, a distance of about 20 miles, the track runs due south as the crow flies. The station called Tangent is a few miles south of Albany Junction.

At the little town of Shedd (see sheet 5, p. 40) there is a creamery and also a flour mill. On the left (east), $2 \frac{3}{4}$ miles away, is Saddle Butte, a volcanic cone from which basaltic rock is Shedd.

Elevation 290 feet. Seattle 278 miles.

obtained for use in road making. A number of these cones, each marking a volcanic vent, probably of Eocene age, rise near the valley border. They are surrounded by alluvium washed into the valley, and a little cone between Shedd and Saddle Butte is nearly buried by these unconsolidated valley deposits.

About 6 miles beyond Halsey, in the vicinity of Alford, near milepost 667 , good views can be had of the irregular crest

Halsey.

Elevation 310 feet. Population 337. Seattle 283 miles.

\section{Harrisburg.}

Elevation 336 feet. Population 453. Seattle 292 miles.

\section{Junction City.}

Elevation 353 feet. J'opulation 759 . Seattle 296 miles.

\section{Irving.}

Elevation 405 feet. Population 867.* Seattle 304 miles. of the Coast Range on the right and the foothills of the Cascade Range on the left.

Harrisburg lies between Muddy Creek and the Willamette, in a country where shifting meandering streams, with many islands, make hard problems for the agriculturist. As a preliminary step to the work of reclamation by drainage, the Federal and State governments are cooperating in making large-scale topographic maps of this part of Willamette Valley.

Near Junction City fields of grain and hay abound and flowers adorn the roadside. Just beyond the station on the left (east) the little blue toadflax shines out. In June the bright blue, purple, or white chicory, the pink malva, and the yellow poppy give beauty to the scene.

In the vicinity of Irving groves of English walnuts and orchards of apples, prunes, and peaches, with large patches of loganberries and other small fruits, alternate with fields of wheat, oats, corn, and grass. Beyond Irving the hills begin to close in on the valley from both sides.

As the train enters Eugene, an attractive city at the head of the wide part of Willamette Valley, Skinner Butte, which rises 260 feet above the track and has a quarry on its north

Eugene.

Elevation 453 feet. Population 9,009 . Seattle 309 miles. slope, is seen near by on the left. The well-marked columnar structure of its basalt is clearly visible and illustrates the character of many of the buttes farther north in the Willamette Valley. All these buttes are composed of solid basaltic lava and appear to be the 
remnants of ancient volcanoes that have been subjected to long erosion and worn down to their solid cores or hard central parts, called plugs because they fill the opening through which the lava had been ejected.

At the University of Oregon, in Eugene, is the large collection of fossils made by Prof. Thomas Condon, who in his day did much to interpret the geology of Oregon.

A stage line up McKenzie River, the largest tributary of the Willamette, which enters the valley near Eugene, leads to the Blue River mining district and gives access to the hunting and fishing grounds about the Three Sisters, snow-clad peaks that carry the largest glaciers in Oregon. The extent of these glaciers during the glacial epoch has not been determined. An ice stream of considerable size probably once occupied the basin at the head of the McKenzie, but no evidence of glaciation has been recognized in the lower McKenzie Valley. Stray bowlders found at a number of places in the Willamette Valley have been more or less doubtfully attributed to ice floating in a body of water which Prof. Condon named Willamette Sound.

Railroad cuts on a branch now being built from the main line at Eugene across the Coast Range to Coos Bay will no doubt display good sections of the Eocene sediments of which this part of the range is largely composed. Another branch runs southeastward from Eugene up the valley of the Middle Fork of the Willamette to Oak Ridge. This branch when extended across the Cascade Range and connected with a line already built from Weed, Cal., to Kirk, Oreg., by way of Klamath Falls will form the main line of the Southern Pacific from Eugene to Weed. This route will avoid the deep crosidrainage valleys of Umpqua, Rogue, and Klamath rivers, will make Crater Lake National Park more easily accessible, and will be superior in scenic and geologic interest to the route now followed.

The rock underlying Eugene is a fossiliferous gray sandstone of Tertiary age.

The University of Oregon is passed on the right (southwest) a mile from the station at Eugene. A mile farther on may be seen an abandoned quarry of the fossiliferous sandSpringfield Junction. stone, also on the right. Beyond it the railroad Elevation 474 feet. Seattle 312 miles. passes through an area of basalt hills, succeeded by shales. At Springfield Junction the shales give place to a gray sandstone full of marine shells like those seen nearer Eugene. This fossiliferous sandstone may be seen in an old quarry on the right side of the railroad. Half a mile beyond Springfield Junction are bluffs of fragmental volcanic material (tuffaceous conglomerate), which continue for nearly a mile. This material is cut by dikes of basalt, which may be seen along the banks of the river. After passing these the railroad takes final leave of Willamette River and in a climb of 20 miles surmounts the low 
divide between the Willamette and the Umpqua. For nearly 200 miles now the route is in the area of generally hilly country which, as noted in the preliminary sketch of the region, separates the Willamette Valley from the Great Valley of California and links the Oregon Coast Range and Klamath Mountains with the Cascade Range and the Sierra Nevada. From Eugene nearly to Greens; a distance of 80 miles, the route traverses Eocene sedimentary or eruptive rocks except where these are covered by alluvium.

At Goshen basalt forms the hill directly opposite the station and extends at least to Spencer Butte, a prominent peak of the same

Goshen.

Elevation 527 feet. Population 414.* Seattle 312 miles.

\section{Creswell.}

Elevation 569 feet. Population 367. Seattle 321 miles. material, which soon comes into view on the right (west). Between Mathews and Creswell is a wide stretch of alluvial plain on which are young orchards of a great variety of fruit trees. From Goshen southward the valley narrows to Walker, being bounded on the left (east) by the end of a bold spur of lava from the Cascade Range. The low hills on the right consist mainly of sandstones and shales, of Miocene age, but at one point a mile east of Saginaw basalt occurs on the right and is crushed for road material.

A branch line from Cottage Grove runs up Row River into the Cascade Range, toward the Bohemia mining district, which has produced gold for many years. Gold was discovered Cottage Grove. here in 1858, and the total production has been beElevation 671 feet. tween $\$ 300,000$ and $\$ 400,000$. The gold-bearing Population 1,834. Seattle 330 miles. quartz veins of this district traverse Tertiary lavas. Quicksilver ore occurs at several places in this region, and an attempt has been made to mine it at Black Butte, on the Coast Fork of the Willamette 17 miles south of Cottage Grove.

The Southern Pacific Co. has a plant at Latham for treating wooden railroad ties with chloride of zinc to increase their durability. This Latham. treatment is called burnettizing, from Sir William Seattle 331 miles. Burnett, who patented the process. Without treatment the ties last about six years, but when burnettized they last eight years. Dated nails are put in all the ties, of which more than 3,000 are treated daily.

Leaving the Coast Fork, the railroad ascends a branch valley to the low pass across Calapooya Mountain that separates the drainage

Divide. basin of the Willamette from that of the Umpqua.

Elevation 779 feet. Seattle 335 miles. Calapooya Mountain is the most northerly of the transverse ridges from the Cascades to the Coast Range and is composed of Eocene sediments and intrusive igneous rocks succeeded on the east by later Tertiary lavas. The terraced slopes of this pass suggest that formerly Umpqua River flowed through it and joined the Willamette. In the course of time, however, its waters found a shorter way through the Coast Range 
to the sea. ${ }^{1}$ Igneous rocks appear near by on the right in the divide and on the left in Wards Butte.

The railroad now enters the Umpqua basin and continues in it for over 100 miles. In the descent down Pass Creek may be seen outcrops of tuffaceous conglomerate (formed of volcanic fragments), which is quarried here and there for riprapping the roadbed. As the general dip of these rocks is northeastward, successively older strata appear in the course of the southwestward descent. Near milepost 619 , on the right, is an old quarry in sandstone which contains numerous fossil leaves of Miocene or Eocene age.

At Comstock there are traces of coal in the sandstones, and a few Eocene shells have been found. The valley of Pass Creek in general is narrow and lies between wooded hills of fine fir

\section{Comstock.}

Elevation 476 feet. Population 321.* Seattle 339 miles. timber. Here and there, however, it widens, and fields of hay and grain extend for some distance up the hillsides. Lumbering is still the principal industry of the region. Anlauf, Safely, and Leona are passed between Comstock and Drain.

${ }^{1}$ A cross section of the qalley cut through the Coast Range by the Umpqua shows certain features that throw light on the later geologic history of the region. In the first place, if the section given in figure 7 were extended it would show that the summits of the hills north and south of the river are more or less flat and at nearly the same level. An observer standing on one of these hills and looking over the

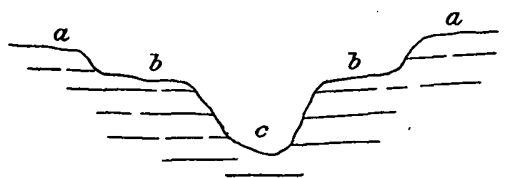

Figure 7.-Generalized section of Umpqua River valley in Coast Range, Oreg. $a$, Peneplain; $b$, earlier valley; $c$, later valley.

country could disregard the present valleys and imagine that his vision was sweeping over a vast rolling surface that was nearly level-a peneplain. The imagination would merely be recalling what was once reality-a land surface worn down nearly to sea level through long erosion by rain and streams. The Umpqua flowed across this surface to the sea.

The next event was a slow rise of the land, in consequence of which the river began to flow faster and to deepen its valley. After it had cut down to a considerable depth the upward movement of the land apparently ceased for a time and the river stopped cutting and began to meander and thus to widen its valley. Later the upward movement of the land was renewed and the river again began to cut down its bed, leaving remnants of its old valley floor as benches or terraces along the sides of its present valley.

A similar relation of peneplain, terrace, and present valley bottom can be deciphered along nearly all the larger streams of the Klamath Mountains and adjacent parts of the Coast Range. This shows that a large area was affected by the same vertical movements of the land.

The Umpqua flows through the Coast Range to the sea in a direct course, which presents a strong contrast with its meandering course east of the range. This difference is due to the fact that in the relatively hard rocks of the Coast Range the stream has been busily cutting down and has not remained long enough at any one level to widen its valley greatly. In the area east of the Coast Range the river has probably flowed over softer rocks and at some stages in its history has had time, between periods of active downward cutting, to swing from side to side, widen its valley, and establish graceful meanders after the common habit of low-grade streams. 


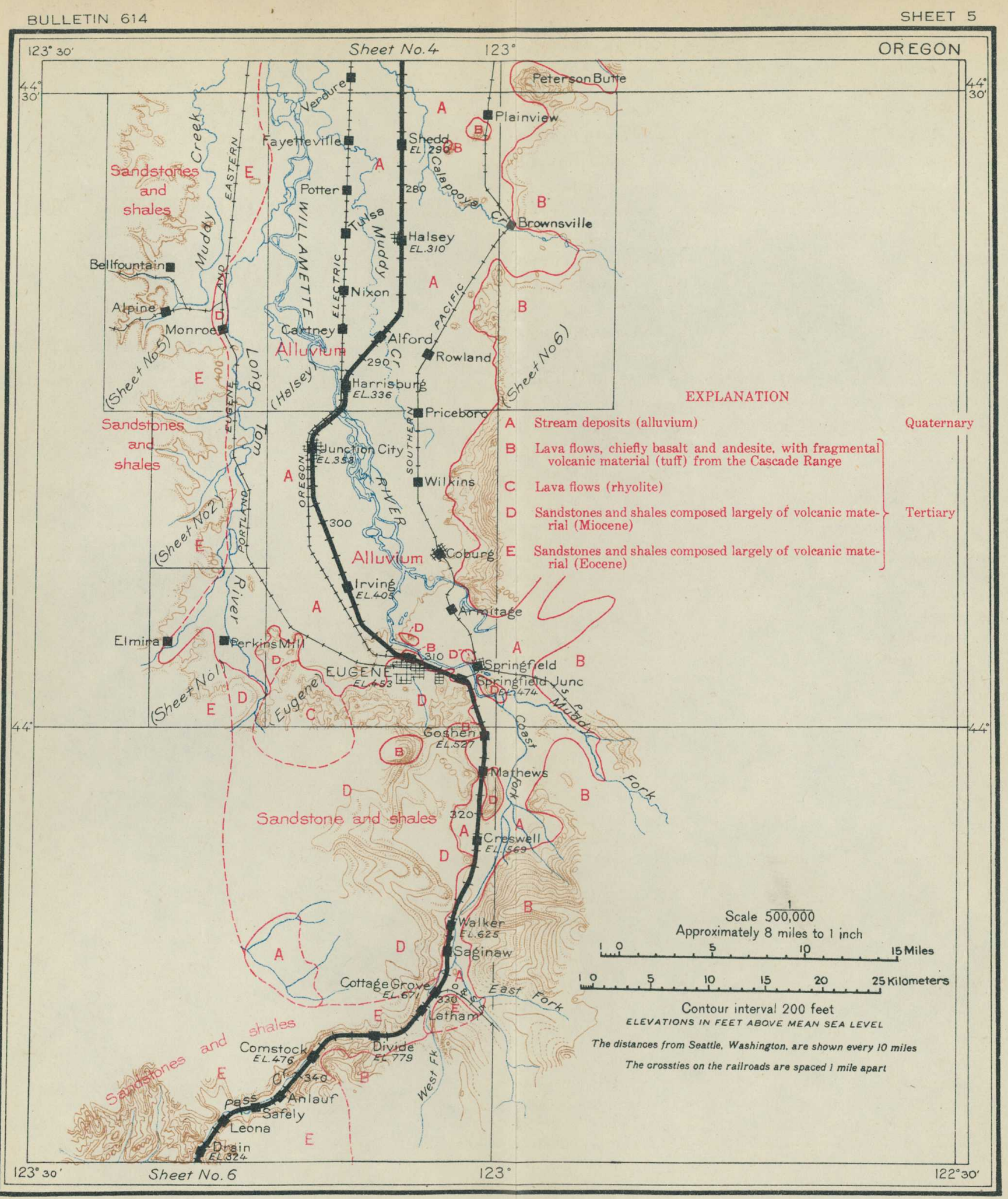


At Drain the railroad crosses Elk Creek and enters a gorge cut in hard $b$. i ; rock, illustrating the fact, already. pointed out, that where the rock is hard erosion is slow and the stream

Drain.

Elevation

Population

Seattle 348 .

reaches?

Near Spring).

From

Yoncalla.

Elevation 38.5 Population 23̈̈. Seattle 353 miles.

Rice Hill.

Elevation 774 feet. Seattle 359 miles. valleys are narrow, but where the rocks are soft, as north of Drain and near Yoncalla, erosion is more rapid and the streams readily widen their valleys. A stage line from Drain down Elk Creek and the Umpqua ater at Scottsburg, about 25 miles from the coast. ost 606, on the right (west), is a mineral spring (Bozwell

calla Valley (see sheet 6, p. 46) grain fields, orchards, and flowered pastures sweep up the gentle hillsides. Many of the hills in this vicinity are composed of Eocene sediments, but some may have been carved from basaltic lavas. The rocks to be seen on the long ascent to Rice Hill are largely shale and sandstone, but include a small mass of basalt. At the summit early in June are golden fields of St. John's wort (Hypericum), locally called goat weed.

Half a mile north of Oakland the railroad crosses Calapooya Creek, just beyond which, on the left, is a small lens of impure limestone of Eocene age that contains great numbers of Oakland. fossils. To the right, beyond the station, can be had Elevation 454 feet. Population 467. Seattle 368 milos. a view of Tyee Mountain, a part of the Coast Range. This range is more even crested here than it is farther north. Turning to the left the railroad goes through a sandstone ridge, near which are some tile works, and comes out on the flat valley called Camas Swale, where the thriving town of Sutherlin has recently sprung up. Camas Swale was once occuSutherlin. pied by Calapooya Creek, but long before man had any knowledge of the region the creek deserted this valley for its present course, north of Oakland, rejoinElevation 548 feet. Seattle 370 miles. ing the old channel just below Stephens. Man has since compelled part of the water of the creek to return to the old valley, where it is used for irrigating numerous thrifty orchards and productive fields. To the west may be seen the Coast Range and, nearer at hand, the entrance to the crooked canyon through which Umpqua River runs northward to the mouth of Elk Creek, west of Drain, before turning to the sea. South of Camas Swale, to the left (east) of the track, are prominent hills of Eocene sandstone. Near Wilbur the sandstone is accompanied by masses of a rather coarsegrained basaltic rock called diabase. This rock is believed to have been forced in a molten condition through the sand that was later consolidated into the Eocene sandstone while that material was being deposited on the sea bottom and to have been in turn covered by more sand. During the period of eruption deposits of tuff, made up 
of fragments of the diabase, were also formed. This tuff contains fossils of the same kinds that are found in the sandstone. As Wilbur is approached some of the sandstone may be seen overlying the diabase and forming prominent.bluffs on the left side.

Beyond Wilbur the railroad crosses some Eocene sandstone and then enters an area of diabase which extends to Winchester. Here North Umpqua River is crossed. To the left is a mill

Wilbur.

Elevation 493 feet. Population 354 .* Seattle 375 miles.

\section{Winchester.}

Elevation 482 feet. Seattle 379 miles. dam, a place of fascinating interest during the salmon season, when the big fish endeavor to jump over the dam instead of going up the fish ladder. Between Winchester and Roseburg the railroad crosses two areas of Eocene sandstone, but these are entirely surrounded by diabase, which continues to. be the prevalent rock along the route as far as Green, 30 miles from Winchester.

A mile north of Roseburg the railroad reaches South Umpqua River, which unites with the North Umpqua to form the main stream in Garden Valley, a few miles to the northwest. At the left are bluffs of lava in which are inclosed some fragments of Eocene shale, as shown in Plate XIII (p. 35). Deer Creek is crossed just north of the town.

From Roseburg, which is the seat of Douglas County, a stage line runs across the Coast Range to Myrtle Point and Coos

Roseburg.

Elevation 487 feet. Population 4,738. Seattle 384 miles.
Bay. This bay is one of the important harbors of the west coast and the port of shipment for the Coos Bay coal field, which produces more coal than any other field in Oregon.

The bold hills about Roseburg are all composed of diabase. About 15 miles northeast of the town, on Little River, a tributary of the North Umpqua, above Glide, Eocene fossils are abundant.

A mile south of Roseburg the deeply decomposed diabase affords good examples of spheroidal weathering. Specimens were collected here for the educational series of rocks prepared by the United States Geological Survey and distributed in 1898 to all the higher educational institutions of the country.

At Green there is a sudden change to the older rocks that compose the Klamath Mountains-conglomerates, sandstones, and shales of Cretaceous age, associated with more siliceous rocks, Green.

Elevation 537 feet. Seattle 389 miles. lime sand limestones, and greenish lavas of Devonian and Carboniferous age.

The core of the Klamath Mountains is composed of large masses of granitic rocks and serpentine, which are intruded into the Devonian, Carboniferous, and Jurassic rocks just mentioned. These older sedimentary rocks cross the country traversed by the railroad between Roseburg and Medford, occurring in belts running northeastward toward the Blue Mountains. 
The hills at Green are smooth and rounded and for the most part without trees. The rocks of which they ara composed are of Mesozoic age, mainly sandstones and shales, with some conglomerate. These rocks are greatly crushed along a belt running northeastward. Southwest of Green station they are associated with a schist composed largely of the beautiful blue mineral glaucophane. This mineral, which is a rather rare variety of hornblende, is found in only a few parts of the world outside of Oregon, Washington, and California. With the glaucophane schist near Green occur a greenish mica schist, some flintlike rocks commonly called cherts, and a greenish igneous rock, referred to as greenstone, which has been so much altered that its original character is in doubt. The best exposure of the blue schist is three-fourths of a mile southwest of some farm buildings on the right (west) at milepost 567 .

This is the only area near the Shasta Route in which these crystalline schists occur. On the other hand, the sandstones and shales with .which the schists are associated occupy a large area that is traversed between Green and Dole, a distance of about 13 miles.

At Carnes, nearly $1 \frac{1}{2}$ miles beyond Green, there is a view to the left up Roberts Creek to Dodson Mountain, a prominent peak standing 3,235 feet above sea level. In the distance are some outcrops of a limestone which is used for lime and cement.

At milepost 565 the South Umpqua is reached again by the railroad, which follows its right (east) bank. Along the stream the crushed sandstones and shales are well exposed to view.

Between Dillard and Dole the river cuts through a ridge, thereby making many fine exposures of the sandstones and shales. Fossils have been found at many places in the Dillard. belt of rocks just traversed, but opinions differ Elevation 546 feet. as to whether the rocks are all Cretaceous or in Seattle 395 miles. part Jurassic.

- From Dole (Ruckels post office) may be seen ahead, on the left, two ridges-one wooded, the other bare. The absence of trees on the

Dole.

Elevation 597 feet. Seattle 402 miles. second ridge is due to the fact that it is composed of serpentine, a rock containing much magnesia and yielding an unfertile soil. Serpentine is an altered form of certain igneous rocks that are as a rule dark and heavy and contain more magnesia and iron than ordinary igneous rocks. Their characteriștic mineral is olivine or peridot, and on this account they are called peridotites.

At milepost 553 the serpentine, which forms a belt more than a mile in width, is visible close at hand. At milepost 551.4 it is cut by dikes of porphyry, an igneous rock containing crystals that are noticeably larger and more distinct than those which make up most of the rock. 
A small cut at milepost 551 shows some fine conglomerate and sandstone lying at the base of a large mass of Lower Cretaceous sedimentary rocks (the Myrtle formation), over which the railroad runs for nearly 10 miles.

About 12 miles northeast of Myrtle Creek station, up the creek, considerable gold has been obtained by washing the gravels (placer mining), chiefly the gravels that overlie the igneous Myrtle Creek.

Elevation 637 feet. Population 429.

Seattle 406 miles. rocks of the region. Beyond Myrtle Creek the railroad crosses South Umpqua River and runs for some miles along the western border of the Missouri Bottom, where many kinds of fruits and grains are grown. On the right (west) is a prominent ridge of Cretaceous sandstone and conglomerate (Myrtle formation). These beds lap up over the serpentine of the ridge beyond.

At Riddle, in Cow Creek valley, the rocks contain many Cretaceous fossils, both plants and marine animals, and among the hills to the

\section{Riddle.}

Elevation 733 feet. Population 187. Seattle 413 miles. southwest, on Thompson Creek, there are also beds containing large numbers of Jurassic fossil plants.

Farther down the valley, among grain fields and prune orchards, may be seen on the right (northwest) a prominent, thinly wooded mountain of serpentine, in which there is a deposit of green silicate of nickel (garnierite). This mineral is extensively mined for nickel in the island of New Caledonia, east of Australia, but the Oregon deposit has not yet been successfully worked.

The distant bare hills seen to the right near the head of the valley are composed of serpentine, but the bluffs nearer at hand, on both sides of the track, consist of Eocene sedimentary rocks. Beyond these is the entrance to Cow Creek canyon, which has been cut through the serpentine belt of Nickel Mountain. The serpentine areas can generally be recognized from a distance by their greenish color and barren aspect. In places, however, they are covered with wild azalea bushes, which suggested the name Azalea for the now abandoned post office at the mouth of Doe Creek.

Between Iron Mountain (milepost 533) and Nichols shales and sandstones are exposed along Cow Creek and have yielded large collections of fossil leaves of Jurassic age, as noted below by F. H. Knowlton. ${ }^{1} \quad$ Many of these leaves belong to various species of ginkgo,

\footnotetext{
${ }^{1}$ The flora of the Jurassic period is in many ways one of the most remarkable fossil floras known. Although not largeit contains probably less than 200 known species-it is practically world-wide in distribution, ranging from King Karl's Land $\left(82^{\circ} \mathrm{N}\right.$.) on the north to Graham Land $\left(62^{\circ} \mathrm{S}\right.$.) on the south, and has been

found in nearly every country on the globe. It is especially abundant in the western hemisphere, occurring in Spitzbergen, King Karl's and Franz Josef lands, Greenland, Siberia, Alaska, and abundantly in Oregon and California.

The luxuriant vegetation and magnificent forests of western and southern
} 
or maidenhair tree, so called because its leaves resemble in shape those of the maidenhair fern. The ginkgo no longer grows wild on

Oregon give so impressive an air of permanence and solidity that it seems as if the conditions now found there must have been unchanged from the beginning of time, yet we have but to turn to the study of the vegetation entombed in the wayside rocks to prove conclusively that during Jurassic time the land was clothed with a flora totally unlike that which now covers it. In the Jurassic period, whose antiquity can be measured only in millions of years, the dominant types of vegetation were ferns and cycads, which were accompanied by smaller numbers of conifers, horsetails, and the curious ginkgo. The types dominant in the flora of to-day are the monocotyledons (grasses, sedges, lilies, palms, etc.) and the still more abundant dicotyledons (oaks, elms, maples, etc.), but so far as we know no plants belonging to either of these great groups existed in Jurassic time.

A few miles southwest of Riddle there has been found a flora of about 70 species, making this one of the richest localities in the world for plants of Jurassic age. Of these species about 20 are ferns, 30 are cycads, and 1.0 are conifers, and the remainder belong to a number of more or less doubtful groups.

The largest number of ferns belong to the extinct genus Cladophlebis, mainly rather small ferns with much-divided fronds. Another wholly extinct form is Tæniopteris, which has long, narrow fronds similar in type to the grass fern, now found in this country only in Florida. Adiantites is believed to be one of the ancestors of the maidenhair ferns, of which there are many living species. There are also three that are thought to belong to living genera-Dicksonia, which is not now found in this country; Polypodium, which is now a very large, mainly tropical group, though a few small species are found in temperate lands; and Thyrsopteris, a fern with finely divided fronds, the only living representative of which is a species in the island of Juan Fernandez.

The cycads were not only the most abundant as regards different kinds but in individuals as well, some collections containing literally hundreds of specimens. They all belong to extinct types, and many of them were evidently large plants, probably with thick stems or possibly with trunks, at the top of which grew large compound leaves disposed in a circle or crown.

One of the most abundant and conspicuous plants of this flora was the ginkgo, of which four or five species have been found here. The ginkgo is now represented by a single species in China and Japan, where it is a more or less sacred tree, found about the temples. It is not certainly known to exist in a truly wild state anywhere. This tree has had perhaps a more wonderful history than any other now living. It appeared at least as early as the close of the great Paleozoic era, and by or even before the Mesozoic

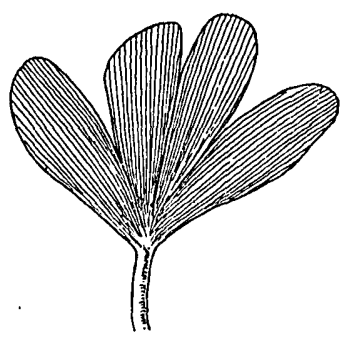

Figure 8.-Sketch of a ginkgo leaf from the Jurassic beds of Oregon.

era it had waxed mighty and had spread over most of the world except the extreme southern hemisphere. It has come down to us so little changed that some of the leaves from the Jurassic rocks of Oregon, apart from their fossil character, are distinguished with difficulty from those of the living tree. (See fig. 8.) Had it not been for the fostering care of man the genus would apparently have become extinct several centuries ago.

Associated with the ginkgo leaves in many of the Jurassic deposits of Oregon are a few branchlets of strange conifers, such as Sphenolepidium, Pagiophyllum, and Brachyphyllum; also a few forms that are referred with more or less uncertainty to living genera, such as Pinus (pine), Sequoia (redwood), Aiaucaria, and Taxites (yew). 
this continent, but it has been introduced from Japan and is common in many of our cities. The rocks in which these leaves are found belong to a formation not yet finally named.

. From Nichols station a backward view may be had of the great flat top of Table Mountain, which is made up of horizontal Eocene Nichols.

Seattle 425 miles. strata. Cow Creek Canyon near Nichols has a depth of about 1,000 feet and is well wooded, though in a few places the woods are marred by fire. The most abundant trees are firs, to which the madronas, with their red-brown bark and shiny oval leaves, afford a pleasing contrast.

South of Nichols station the fossiliferous Eocene, Cretaceous, and Jurassic strata are succeeded by a very thick series of sandstones and shales, which form the slopes of Cow Creek canyon for nearly 15 miles. No fossils have been found in them in this area. This great mass of sandstones and shales (the Dothan formation, of Jurassic age) is much crushed, so that the layering characteristic of rocks that have been deposited in water has been obscured.

From West Fork mail is carried over a trail to the lower Rogue River country and to Gold Beach, on the coast. About 3 miles south of West Fork a large slide occurred some years ago

\section{West Fork.}

Elevation 1,050 feet. Seattle 436 miles. on the west slope of the canyon and blocked railroad traffic completely for three months. Four miles of track had to be changed and two new tunnels cut.

At a number of places along this part of Cow Creek old stream gravels, lying on hillside benches above the channel of the present creek, have been worked for gold.

About 4 miles beyond West Fork the sandstones and shales of the Dothan formation are succeeded by a much more variable set of rocks, chiefly slates and greenstones. The slates are known as the Galice formation, from the mining district of that name in the Klamath Mountains, farther south. They contain fossils which are similar to those collected from the slates (Mariposa slate) of the gold region of the Sierra Nevada, in California, and which indicate Jurassic age. The Galice formation is older than the Dothan formation and ought normally to lie beneath it, but earth movements since the beds were deposited have reversed these positions and the Galice at this locality now lies on top of the Dothan. Such an overturn is sometimes brought about by folding of the beds, sometimes by faulting whereby older beds are slid on top of the younger ones.

\section{Reuben.}

From Reuben spur (see sheet 7, p. 60) a wagon

Elevation 1,376 feet. Seattle 445 miles.

Glendale is greenstone. road leads to the Reuben Mountain mining district, which lies about 10 miles to the northwest. The prevailing rock of the region between Reuben and 
GEOLOGIC AND TOPOGRAPHIC MAP OF THE

\section{SHASTA ROUTE}

From Seattle, Washington, to San Francisco, California

Base compiled from United States Geological Survey Atlas

Sheets, from railroad alignments and profiles supplied by

the Southern Pacific Company and from additional inform-

UNITED STATES GEOLOGICAL SURVEY

\section{GEORGE OTIS SMITH, DIRECTOR}

David White, Chief Geologist $\quad$ R. B. Marshall, Chief Geographer 1915

Each quadrangle shown on the map with a name in parenthesis in the
lower left corner is mapped in detail on the U. S. G. S. Topographic lower left corner is
Sheet of that name.

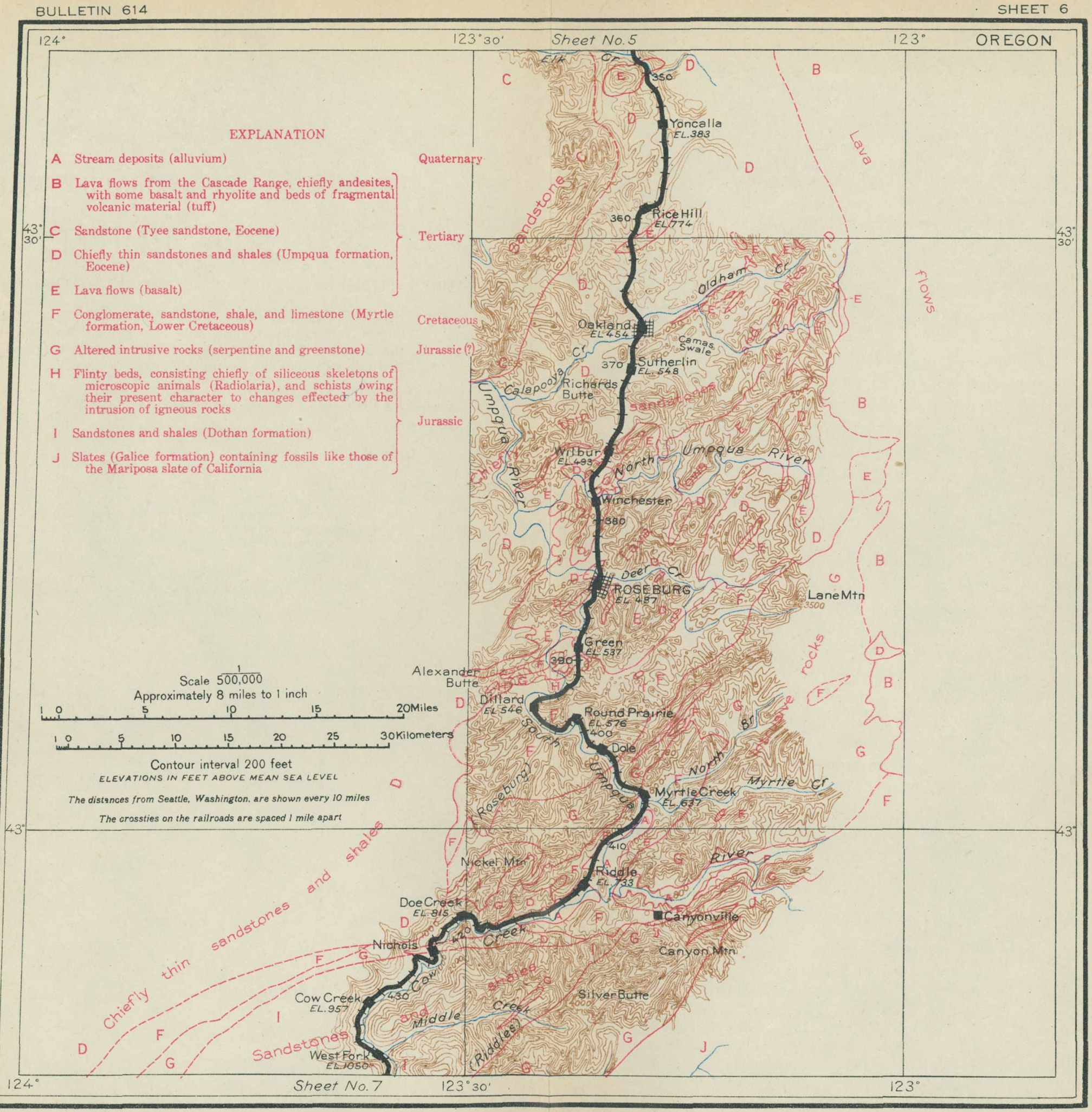


Northwest of Glendale there are two prominent peaks of greenstone-Grayback, 4,033 feet above the sea, and Panther Butte, 3,517 feet. On leaving Glendale the train passes over a

Glendale.

Elevation 1,437 feet. Population 646 . Seattle 449 miles. mass of siliceous reddish lava (rhyolite), and beyond this is the greenstone that forms the divide between Umpqua and Rogue rivers. The crest of the divide also forms the boundary between Douglas and Josephine counties. The dividing ridge is penetrated by a straight tunnel (No. 8), 2,828 feet in length and 420 feet below the summit. The basin of Rogue River is traversed by the railroad to the summit of the Siskiyou Mountains, a distance of 93 miles. Beyond the tunnel the railroad descends by a long sweeping curve into the Wolf Creek valley.

The station of Wolf Creek was formerly one of the hostelries on the old California-Oregon stage line. The small

\section{Wolf Creek.}

Elevation 1,319 feet. Population 232.*

Seattle 455 miles. power house on the left (south) is the northernmost station on the power line from Gold Ray, 50 miles ahead on the edge of the Rogue River valley. Wolf Creek runs through a gold country, and in the early days many gold placers were worked in this vicinity.

Much of the primeval timber along Wolf Creek has been pine and oak, but madrona and other broad-leaved trees are now taking the place of the conifers. Buck brush (Ceanothus velutinus), with its broadly ovate or elliptical shiny leaves, and tree myrtle (Ceanothus sorediatus), with its small oblong ovate light-green leaves, are common in the thickets of chaparral in southern Oregon. Blue brush or California lilac (Ceanothus thyrsiflorus), with its tiny leaves and blue to white lilac-like flowers, which are good for cattle, soon appears in increasing numbers. By the roadside in June plants of the socalled Oregon grape or Mahonia (Berberis aquifolium), the State flower of Oregon, are full of bluish berries.

At milepost 497 the railroad crosses Grave Creek close to a placer mine, where water-supply pipes for hydraulicking and the gravel dumps left from former operations can be seen. Beyond Grave Creek is a broad belt of slates, probably for the most part Mesozoic. The name Grave Creek is suggestive of the old rough days of gulch mining, and the gravels along the creek did in fact yield considerable gold to the early placer miners. The metal in the placers is thought to have been derived by erosion from the Greenback lode, on the divide north of the creek. This lode was worked years ago, but the mine is now idle. 
From Leland station there is a good view not only of the slates near by but also of the hilly country. Here the manzanita, ${ }^{1}$ which is abundant farther south, makes its first appearance. Leland.

Elevation 1,218 feet. is at an elevation of 1,700 feet, is 2,205 feet long, and Population 239.* Seattle 463 miles.

runs 300 feet below the summit. The tunnel is cut in black slates of Mesozoic age. On the right (west) as the train emerges is Tunnel Creek, down which it continues for about a mile and then, turning sharply to the left, enters an area of rock different from any yet seen along the route. Most people, including quarrymen, would call this rock granite, and such for all practical purposes it is. When fresh it has the characteristic gray speckled appearance of granite. ${ }^{2}$

Hugo lies in the area of granodiorite, which is of irregular outline and extends southward for 15 miles, to the vicinity of Applegate River, beyond the town of Grants Pass. The rock

Hugo.

Elevation 1,316 feet. Seattle 469 miles.

at the surface is generally decomposed and crumbling, and is consequently more easily eroded than the harder slates and greenstones, and the country underlain by it is less rugged than that north of Hugo.

From Merlin a stage line runs to Rogue River, about 4 miles to the west, and down that stream to the Galice mining Merlin.

Elevation 932 feet. Population 787.* Seattle 474 miles. district. In the country beyond Merlin, on the left (northeast), an attempt is being made to establish orchards of apples, peaches, grapes, and other fruits without irrigation.

A low divide is crossed between Merlin and the town of Grants Pass, on Rogue River. Along the railroad may be seen cuts and

1 This shrub (Arctostaphylos patula), growing from 3 to 5 feet high in Oregon but much taller in parts of California, is sure to attract the attention of one who has never seen it before. It has a smooth bark of rich chocolate color, small palegreen roundish leaves, and berries that resemble diminutive apples. It is this resemblance that gives the shrub its common name, Spanish for little apple, by which it is everywhere known on the Pacific coast. Bears are very fond of these berries. The manzanita covers many hills in California with a stiff and almost impenetrable growth, as will be seen near Mount Shasta. Its wood is hard, and the blaze from an old gnarled root cheers many a western fireside.
${ }^{2}$ The geologist, who can with the microscope distinguish all the various minerals that compose rocks, has found that this rock is not strictly a granite but is intermediate in composition between true granite and a similar but darker rock containing less silica (quartz), known as diorite, so he would call it granodiorite. Like granite, granodiorite is an intrusive igneous rock. It was forced in molten condition, probably about the close of Jurassic time, into the slates and greenstones that now surround it, and then it slowly crystallized and solidified under a thick cover of rock that has since been worn away by erosion. Granodiorite is abundant in the Sierra Nevada and the Cascade Range. 


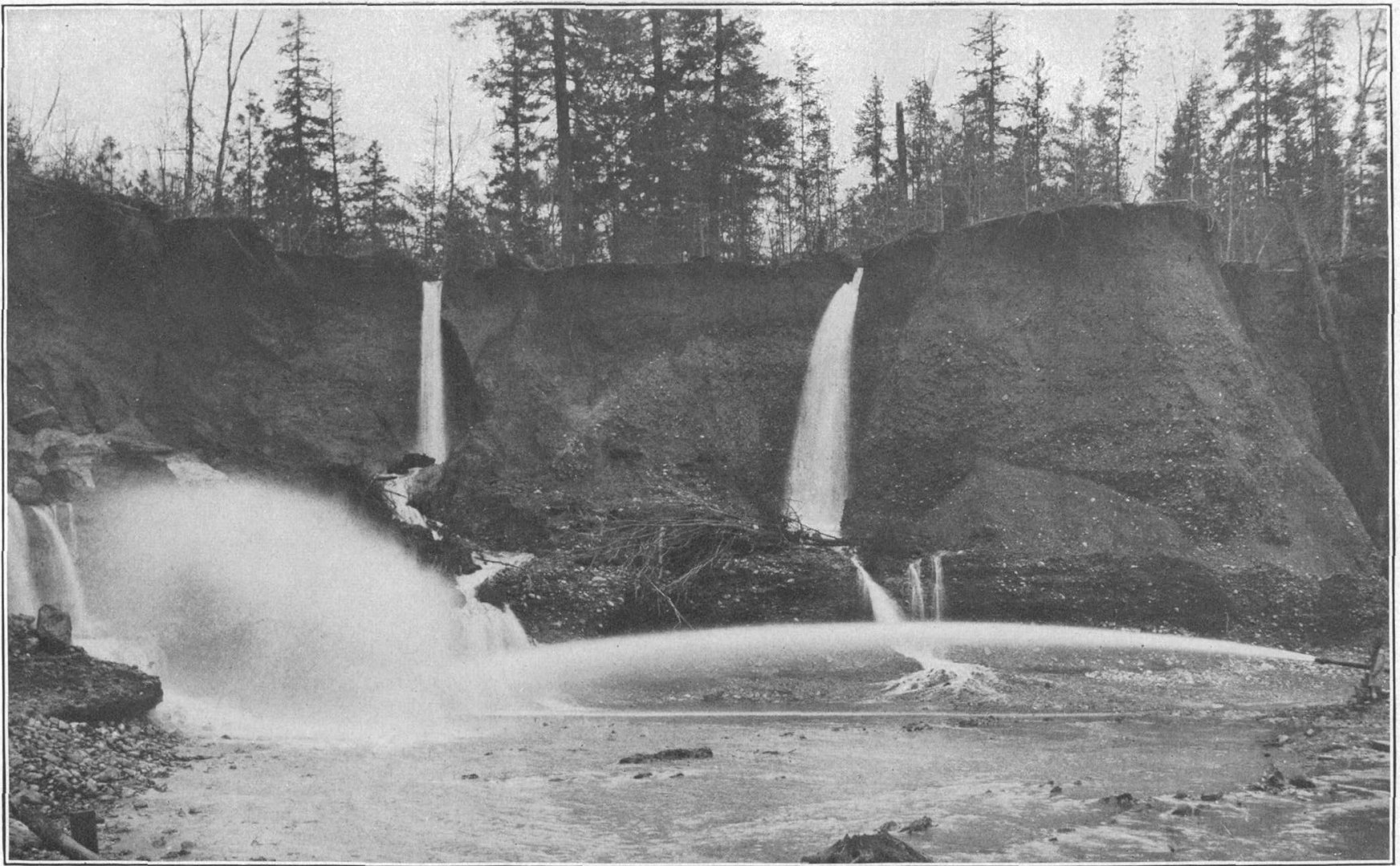




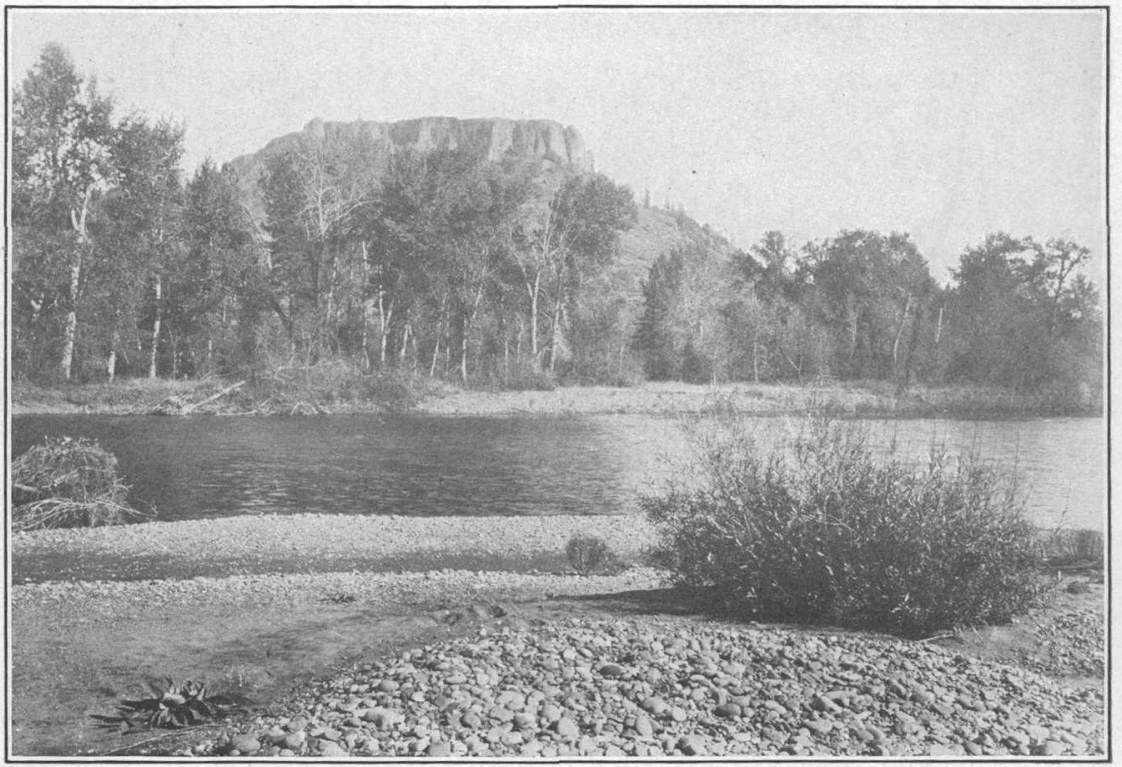

A. TABLE ROCK, AT ENTRANCE TO ROGUE RIVER VALLEY, OREG.

A lava flow from the Cascade Range caps the softer beds and protects them from erosion.

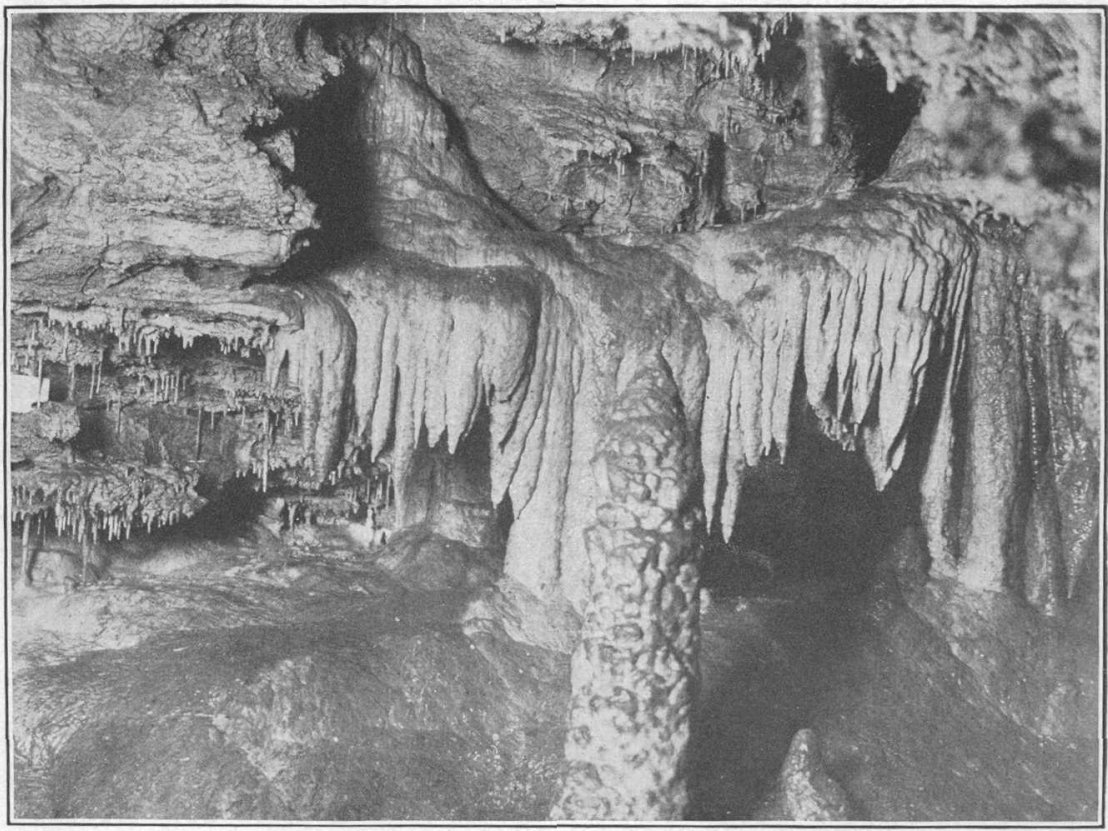

B. OREGON CAVES, SOUTHWEST OF GRANTS PASS, OREG.

Stalactites, like icicles, hang from the roof of the cave; stalagmites point upward from the floor. When they meet they form a column. These forms are composed of carbonate of lime deposited from solution in water. Photograph copyrighted by Weister Co., Portland. 
quarries in the deeply disintegrated granodiorite, which is used by the railroad as a substitute for gravel about its stations.

Grants Pass, named after Gen. U. S. Grant, who as a captain quelled. an Indian uprising on Rogue River in the early fifties, is the seat of Josephine County and the mining center of southGrants Pass. western Oregon. From 1903 to 1912 the placer Elevation 963 feet. mines of this part of the State (Pl. XIV) produced Population 3,897 . Seattle 483 miles. $\$ 2,014,715$ in gold, and the vein or lode mines $\$ 1,523,226$. A stage line runs from Grants Pass through Kerby and Waldo to the coast at Crescent City, and a railroad to the same place is now under construction.

Grants Pass is the point of departure for a visit to the Oregon Caves, the largest caves known on the Pacific coast. The caves are about 25 miles nearly south of Grants Pass and may be reached by. automobile and trail. They have bèen formed by the solution of limestone and are ornamented by a great variety of beautiful stalactites and stalagmites (Pl. XV, B) composed of carbonate of lime: deposited by water. These caves have been set apart by the Federal Government for preservation as a national monument.

Two miles beyond Grants Pass, at the eastern edge of the granodiorite area, is obtained the first near view of Rogue River, the largest stream of southwestern Oregon. Its water, derived in part from the snows about Crater Lake, is usually clear. The railroad for 20 miles upstream follows its valley, which is in places a canyon, but is generally wide enough to contain some tillable bottom land: The rocks through which this narrow valley has been cut are Paleozoic in agemuch older than any rocks that have hitherto been seen along the route. They comprise slates, limestones, and greenstones and, like: the Dothan and Galice formations, already noted, have been so folded and faulted that the Paleozoic rocks are thrust over upon the much younger Galice formation. These Paleozoic rocks resist erosion. better than the granodiorite, and therefore the valley cut through them by Rogue River remains narrow.

At $3 \frac{1}{2}$ miles east of Grants Pass, on the left (north), behind a little hill of granodiorite on Bloody Run Creek, is the Golden Drift:placer mine, now idle. About 5 miles farther north is another small intrusive mass of granodiorite, about which are some small mines on gold-bearing quartz veins.

From milepost 469.4 up the river the Savage Rapids are in view. Old Baldy and Fielder Mountain, peaks of greenstone, stand out prominently on the left (north) from the point where the railroad crosses the line between Josephine and Jackson counties (milepost 469.1).

$96286^{\circ}-$ Bull. $614-15-4$ 
At Rogue River (formerly called Woodville) are fields of corn and wheat and young orchards. Nearly opposite milepost Rogue River. 462, on the right (south) side of the river, is the mouth Elevation 1,025 feet. of Foots Creek, whose gravels have for years been Seattle 492 miles. worked for gold.

At milepost.458, in the outskirts of Gold Hill, there are a limestone quarry and a cement plant. The limestone is a lenslike mass in a belt of slate more than a mile wide, which may

Gold Hill.

Elevation 1,108 feet. Population 423.

Seattle 499 miles. be traced to the southwest for a long distance and contains numerous similar lenses of limestone. Fossils are rare in this limestone, but those found suggest Carboniferous age. Other limestone lenses, farthar west in the area of Paleozoic rocks and not exposed on the railroad, contain fossils of Devonian age. Therefore the Paleozoic rocks of this region are in part Devonian and perhaps in part Carboniferous.

Rogue River is crossed just beyond Gold Hill, and the river bed affords a near view of some of the greenstone, which at this place is clearly made up of fragments of volcanic rock. The greenstones associated with the slates and limestones are in fact old lavas, partly poured out molten and partly blown out in fragments from volcanoes that were active in Paleozoic time. These lavas, originally black or gray, have become greenish through the slow changes of age. As will be seen later, these Paleozoic slates, limestones, and greenstones make up much of the Klamath Mountains.

After crossing the river the railroad turns northward opposite the hill from which the town of Gold Hill was named. This hill, which is 2,640 feet above sea level, consists of greenstone and serpentine, into which has been intruded some granodiorite that now forms the hilltop. Small "pockets" of rich gold ore were found here in early days.

Between mileposts 454 and 453 there is much of a coarse-grained dark rock composed chiefly of the mineral pyroxene (an ironmagnesium silicate) and called pyroxenite. This is an igneous intrusive rock and was probably very closely related to the rock that in the course of time changed into the serpentine of Gold Hill.

Northeast of Gold Hill, just across the river from the railroad, is Table Rock (Pl. XV, $A$ ), named from the flat black capping of basalt, which is part of a flow of lava that long before historic times spread over this region from some volcano in the Cascade Range. The lava flowed over comparatively soft beds of shale, sandstone, and conglomerate of Cretaceous and Tertiary age. Afterward erosion cut through the lava in places and attacked the softer rocks underneath, but Table Rock, with its protective capping, remains and shows how much has been washed away around it.

Beyond Table Rock the country opens out into that part of the valley to which the name Rogue River valley is especially applied. 
The valley lies between the Klamath Mountains on the west and the Cascade Range on the east. The highest point in view in the Cascade Range is Mount McLoughlin (9,760 feet), named after Dr. John McLoughlin, of the Hudson's Bay Co. The mountains are composed of relatively hard rocks, but the granodiorite and the Cretaceous and Tertiary sedimentary rocks that underlie the fertile fields of the valley are comparatively soft. This difference in hardness has enabled the river and its tributaries to carve out a wide, flat-bottomed valley. The sedimentary rocks of the valley lie in beds sloping eastward under the lavas of the Cascade Range, but they overlie the older rocks of the Klamath Mountains, including the granodiorite, and once extended much farther west. It will be noticed from the cross section (fig. 9) that the Cretaceous beds dip at a different angle from the slates of the Klamath Mountains and that, if they were restored to the west, they would lie across the upturned edges of the slates. This relation is known to geologists as an unconformity.

The train turns up the southeast arm of the valley, drained by Bear Creek, which joins Rogue River near Table Rock, and passes through Tolo (elevation 1,196 feet, 452 miles from San Francisco) and Cen-

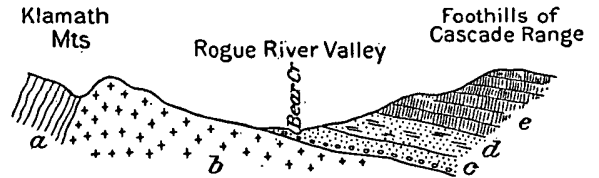

FIgURE 9.-Section of Rogue River valley near Phoenix, Oreg. $a$, Slates, limestones, and lavas of Palcozoic (Carboniferous?) age; $b$, granodiorite; $c$, Cretaceous conglomerate, sandstone, and shale (Chico formation); $d$, sandstones and shales containing Eocene leaves; $e$, lava of Cascade Range. tral Point (elevation 1,290 feet, 446.7 miles from San Francisco), where the traveler may see fine fruit orchards (Pl. XVI) and grain fields, before arriving at Medford.

Medford, the chief town of the Rogue River valley, is rapidly growing in consequence of its relation to the fruit industry of the valley, the mining region of the Klamath Mountains on the Medford.

Elevation 1,398 feet. Population 8,840 . Seattle 514 miles. west, and the forests and resorts of the Cascade Range on the east. From Medford the traveler may continue on the main line or make a detour, partly by automobile stage, through Crater Lake National Park, returning to the main line at Weed; Cal. The beautiful scenery of this side trip will amply repay anyone for the additional time it requires. To those interested in geology or in the ways by which mountains and valleys have come to their present forms the Crater Lake route will prove exceptionally interesting.

From Medford a short branch line (the Rogue River Valley Railroad) runs west to Jacksonville, and from Crater Lake Junction, a mile north of Medford, the Pacific \& Eastern Railroad extends for 33 miles toward Crater Lake.

[The itinerary southward from Medford is continued on p. 56.] 
MEDFORD TO WEED VIA CRATER LAKE.

The distance from Medford to Crater Lake by automobile stage is 79 miles. The first 20 miles lies through orchards, mainly of apples and pears, over gravel plains spread out by the streams as they issue from the mountains, and through foothills where the sandstones and shales (Eocene to Miocene) of the valley dip eastward under the lava flows of the Cascade Range.

At 31 miles from Medford the road crosses Rogue River, and thence for 16 miles, to the mouth of Mill Creek, it follows the north bank of the river through a deep canyon. From the roadway may be had good views both of the canyon and the uplands bordering the wider valley to the west.

Near Prospect (elevation 2,780 feet) Rogue River is again crossed at the head of its canyon. Here the river in a quarter of a mile falls 325 feet in a series of cascades, at the foot of which Mill Creek, in a fall of great beauty, 150 feet in height, joins Rogue River. Near Prospect the primeval forest begins, and for miles the smooth road built on terraces of lava affords fine forest views.

At Union Creek, 58 miles from Medford (elevation about 3,500 feet), there is a delightful camping place near Natural Bridge and Union Falls. The Union Falls are really cascades over some black lava (basalt), and there are similar cascades at Natural Bridge, a little farther downstream. These cascades came into existence in the following way. In late geologic time (Quaternary) a lava flow came down the bed of Rogue River with scant regard for previous water rights. When the lava had reached a point about a quarter of a mile below Natural Bridge it cooled and stiffened sufficiently to stop. The basalt still shows the ropy forms in which it congealed and the bubble cavities or vesicles formed by the steam that nearly all lava contains. Shortly afterward a second stream of lava came down on top of the first but did not run quite so far. The river now reoccupied its bed as well as it could and at first cascaded over the ends of the lava flows. In course of time it wore back gorges, 60 feet deep, in the basalt, and it is still busy at the same task. At Natural Bridge the stream has discovered and doubtless enlarged an old tunnel such as is often formed in lava streams by the continued flowing of the deeper molten material after a solid crust has formed above it.

Ten miles beyond Union Falls is the entrance to Crater Lake National Park. The lake is deeply set in the crest of the Cascade Range, the surface of the water being at an altitude of 6,177 feet. It is encircled by a cliff from 500 to nearly 2,000 feet high. From the top of this cliff the ground slopes away gently on all sides, so that the lake partly fills a great cup or pit in the summit of a broad conical mountain. This comparatively low mountain is all that remains of a once mighty volcano, Mount Mazama (Pl. XVII, $A$ ). In all probability no human 


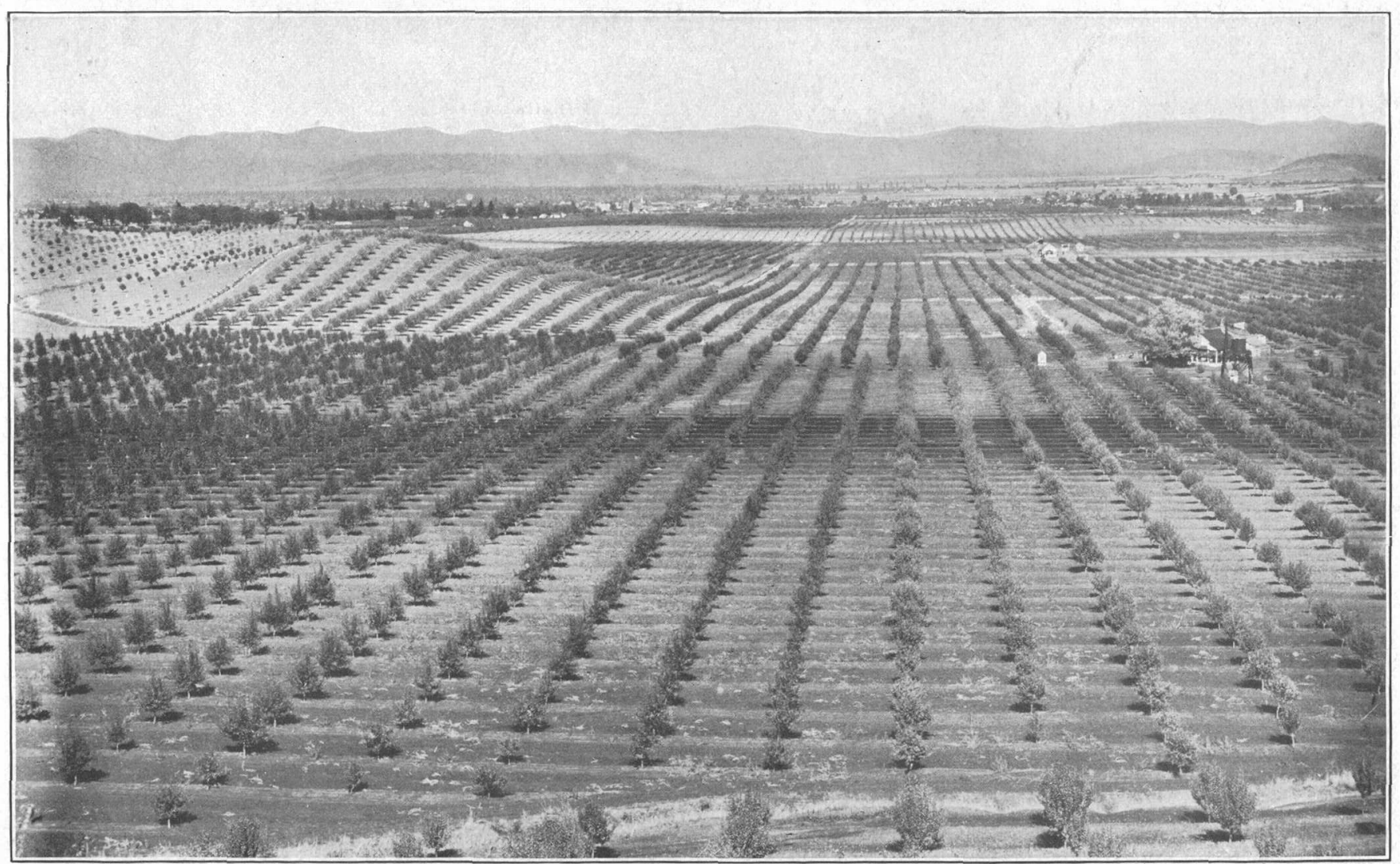

PEAR AND APPLE ORCHARDS IN ROGUE RIVER VALLEY, OREG. 


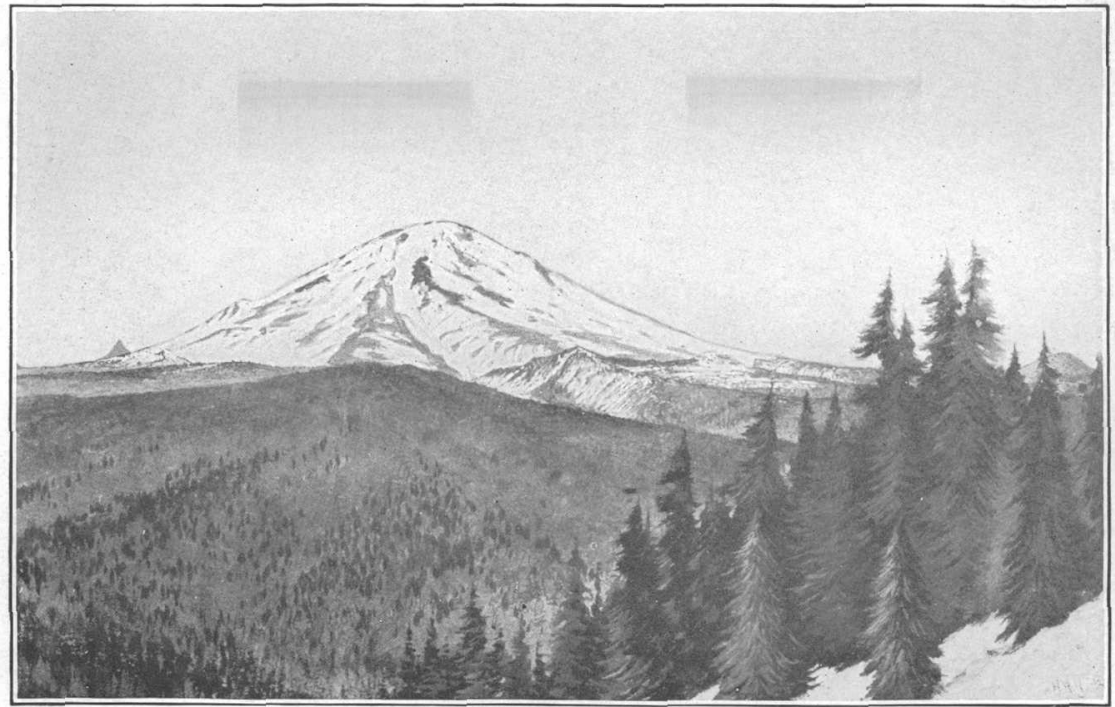

A. MOUNT MAZAMA RESTORED.

As it appeared before it collapsed to make the great pit now half filled by Crater Lake, which is nearly 2,000 feet deep.

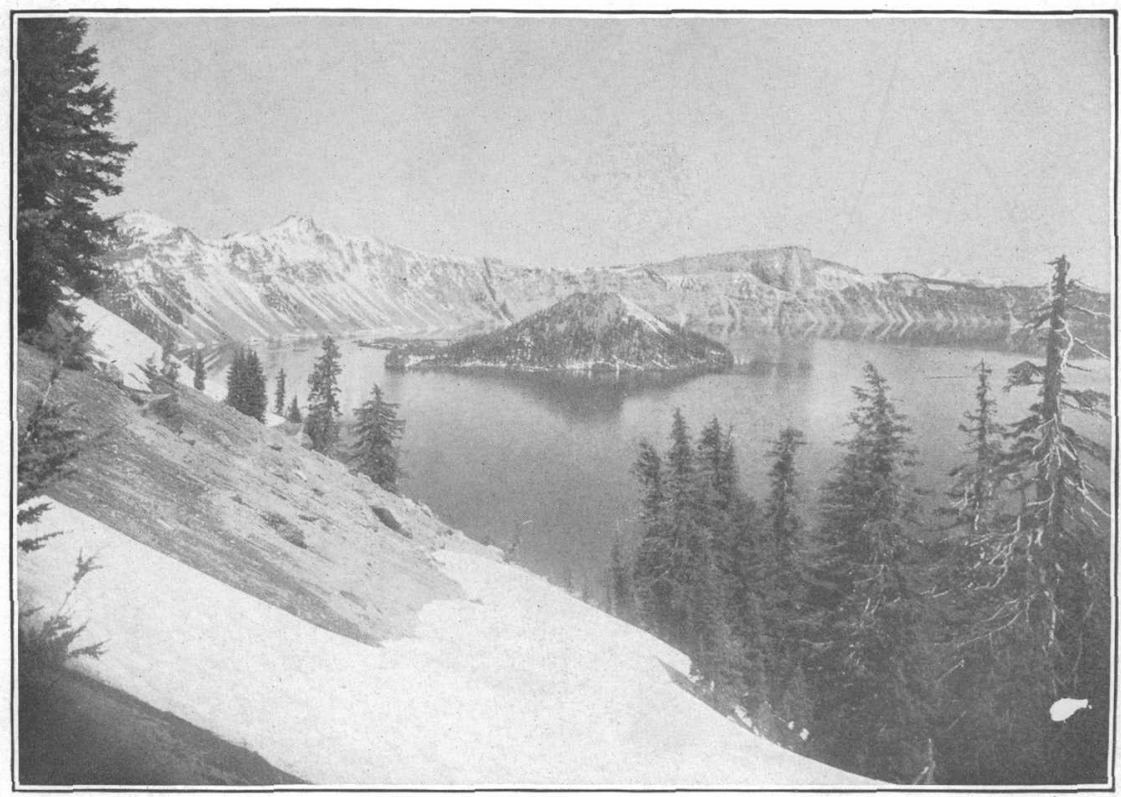

B. WIZARD ISLAND, CRATER LAKE, OREG.

A small volcano (cinder cone) that has grown up in the great pit formed by the collapse of Mount Mazama. Across the lake is Llao Rock, formed by a lava flow from Mount Mazama that now fills a little valley in the rim of the crater. 
eye ever looked upon this peak, but geologists know that it existed and that glaciers crept down its flanks and gouged out its canyons. Through some cause unknown this mountain collapsed--its top fell in, leaving the hole now occupied in part by the lake, 2,000 feet deep.

Wizard Island (Pl. XVII, $B$ ) is a small volcanic cone built up from the bottom of the pit and now probably extinct. From it may be had superb views of the cliffs that surround the lake. The sky line of these cliffs shows U-shaped notches (Pl. XVIII, p. 54), which are sections of the glaciated valleys that formerly headed high up on Mount Mazama.

From Crater Lake Lodge, situated on the rim 1,000 feet above the lake, excursions may be made to many places of interest, especially the glaciated valleys of Sun and Sand creeks, the great pumicecovered flow of Llao Rock, and the latest lava flow of all, at Rugged Crest. A trip by boat to Wizard Island and around the lake gives the visitor an opportunity to fish and to see the materials of which the great volcanic cone was built and the way in which these have been piled up in successive layers.

From the lake to Chiloquin, a station on the Southern Pacific Co.'s new line from Weed, Cal., via Klamath Falls, the distance is 35 miles. This new line is intended when complete to be the main line between Weed and Eugene, Oreg. From the lake to Klamath Falls by the automobile road the distance is 65 miles. From the point where the road leaves Crater Lake the view over the broad platform of the Cascade Range (Pl. XIX, p. 55) includes the great cones of Shasta and Pitt, with many others, large and small, each once an active volcano.

The descent from the rim of Crater Lake is at first very steep over a moraine (the bowldery deposit left in front of a glacier) to the great spring at the head of Anna Creek. The road affords fine views of the canyon of Anna Creek, cut deep in volcanic ejecta. Near its head the rocks have been eroded into cigar-shaped pinnacles and farther down. systems of parallel cracks in the rocks (jointing) give striking columnar effects. On the east, across Anna Canyon, stands Crater Peak $(7,265$. feet), one of the outlying basalt cones built up on top of the flows of andesite that made the bulk of Mount Mazama. After flowing through some finely forested, gently sloping country Anna Creek enters upon the broad alluvial plain of upper Klamath Lake.

Fort Klamath, on the western border of the Klamath Indian Reservation, is now only a small-village but was an active Army post at the time when military force was necessary to keep the Indians in order. Sev ral of the old fort buildings are still standing. Here it was that the notorious chief known as Captain Jack was tried and hanged for the part he played in the Modoc war, the scene of which was among the lava beds about 60 miles southeast of Fort Klamath. The Klamath Indian Reservation contains much fine pasture and farm land, as well as forest, and many of the Indians are engaged in agriculture. 
A few miles from the fort are the well-kept buildings of the Klamath Indian Agency.

Wood River, the clear, cold stream that supplies the fort and agency. with water, rises on a fault whose course is marked by a prominent bluff leading up toward Crater Lake. The water of the river may possibly be derived in part from the lake by underground flow along the fault fissure.

Five miles beyond the agency is Chiloquin, a small village on Williamson River. The water of Williamson River, though clear, has the brown color characteristic of streams that drain swamps. This river is noted for its trout, but the Sprague, into which it empties half a mile below Chiloquin, is turbid and contributes to the muddiness of upper Klamath Lake.

At the crossing of Sprague River an excavation for a ditch reveals bright-colored lake beds, which evidently underlie the soil of the plain. Modoc Point, on the northeast side of Upper Klamath Lake, is part of a bold bluff of dark lava (basalt) lapped by the waters of the lake. The bluff marks the course of a northwesterly crack along which the rocks on the southwest side have sunk or those on the northeast side have risen-in other words, the lavas are faulted. The bluff is part of the southwest edge of a block of the earth's crust that has been tilted toward the northeast. The effect of the fault has been to form the hollow; deepest on the northeast and shoaling to the southwest, in which the lake lies. There are other faults of the same kind and general direction in southeastern Oregon, and a number of these have produced lake basins.

From Modoc Point Mount Pitt (9,760 feet) may be seen by looking west across Pelican Bay. To the south, across the main lake, appears the snowy peak of Shasta (14,350 feet).

The Plum Hills, near Algoma station, have been carved by erosion from an uptilted fault block such as has just been described. The fault fissure runs along the west base of the hills. Dipping east under the lava which forms the upper part of the hills are some fine, thin-layered beds which were deposited in a lake that existed before the lava was erupted.

Klamath Falls (elevation 4,120 feet), at the outlet of Upper Klamath Lake, is a thriving town, to whose growth the new through line of the Southern Pacific, now under construction, and the great Klamath reclamation project of the Government have given added impetus. The Klamath Basin, which lies partly in California and partly in Oregon, embraces several thousand acres. Much of the land to be reclaimed and irrigated was covered by lakes and marshes, but the waters are being drained off and the land, divided in to farms, is being irrigated by the Government canals. About 30,000 acres are now under irrigation, and when the system is completed it will include 72,000 acres of irrigable land. Practically all the uplands, 


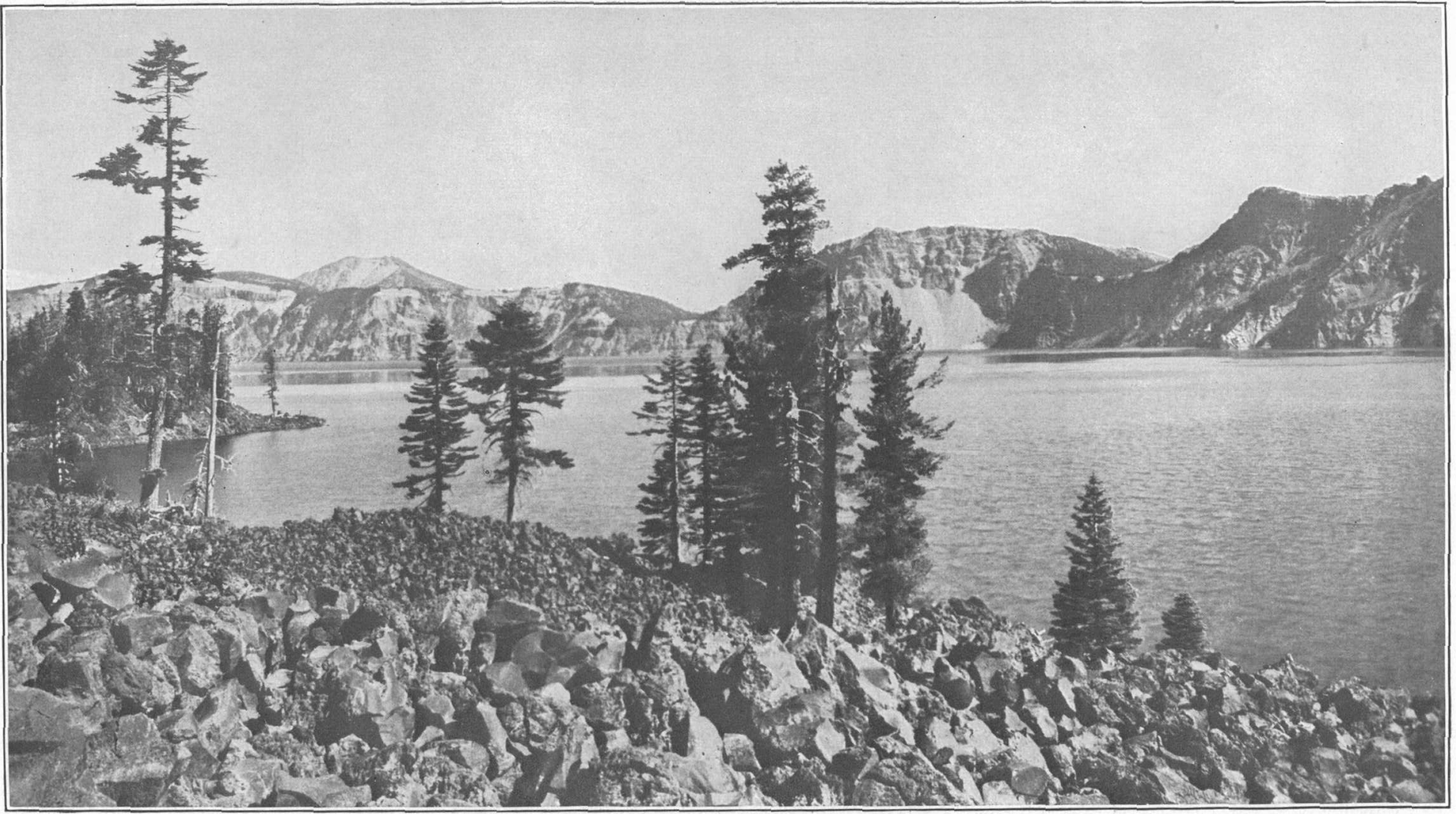




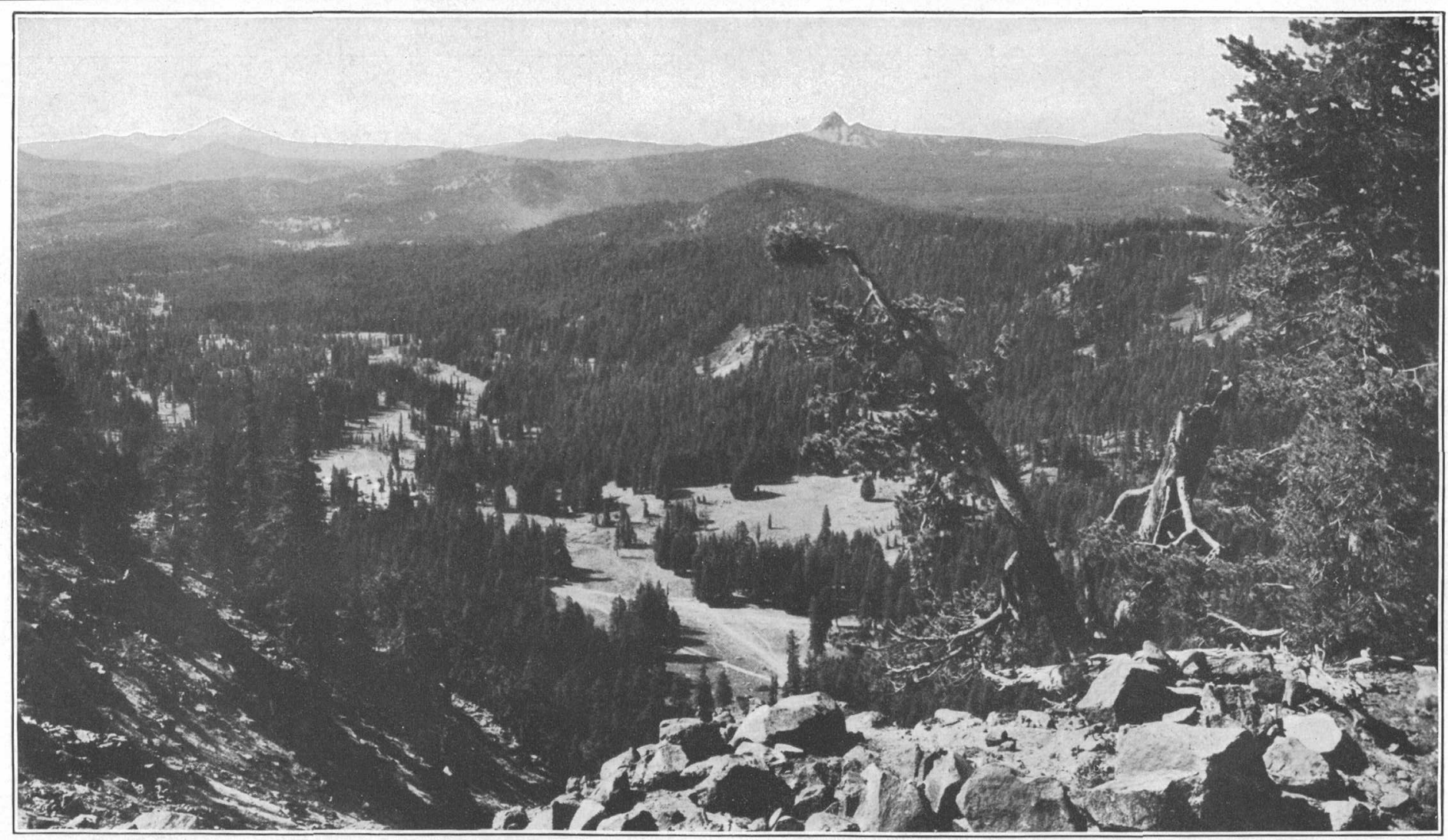


which comprise the greater part of the area, are privately owned, a portion being in large holdings which, under the terms of the reclamation act, must be subdivided into tracts of not more than 160 acres and sold to actual settlers. The public lands, including much of the lake areas, are at present withdrawn from entry but will later be opened to homestead entry.

Beyond Klamath Falls the railroad crosses a great area of tule (too'lay, the Spanish name for a species of rush (Scirpus lacustris) common on the swamp lands of the Pacific coast). The reclamation of this area is part of the Government project. On the right is Klamath River, and beyond is the gap in the Cascade Range through which the river makes its way. A flow of comparatively recent lava in the gap has formed a dam which by ponding back the river has contributed to the formation of the lakes and swamps of the country now being traviersed.

At Midland, among the marshes, the traveler enters a national bird reserve, where ducks, geese, and many other waterfowl are abundant and are secure from molestation. Near Worden, which lies among low lava hills, apple orchards and fields of grain appear as if by magic, surrounded by sagebrush and cedars.

By several tunnels through ridges composed of bright-colored beds of tuff (lava particles thrown out by the explosive action of volcanoes) Dorris (elevation 4,238 feet) is reached. Beyond it are other small towns surrounded by hay and grain fields. The hills become better wooded as the Cascade Range is approached. The eastern front of the range, as seen from Macdoel (elevation 4,256 feet) and Mount Hebron $(4,237$ feet), is so abrupt as to suggest that this part of the range may have been uplifted above the country to the east by a fault. The region about Mount Hebron is a fine cattle country. Forests become more conspicuous at Jerome, where the railroad crosses a low divide between the drainage basins of Butte Creek and Little Shasta River.

At Kegg there is some well-stratified dark volcanic material that is widely used for railroad ballast. This material, somewhat resembling cinders, was blown out from some volcano. Such fragments of cindery lava are known as lapilli (little stones). The rich green pastures of the small valleys of this part of the route are bright with flowers and dotted with contented cattle. They are surrounded by dark forests of yellow pine (Pinus ponderosa), which is now being extensively cut for lumber.

From Bray (elevation 4,648 feet) may be seen Goose Nest Mountain (see sheet 8, p. 64), on the right (west), directly across the valley. Another low divide (5,078 feet) is crossed, and Grass Lake, surrounded by swampy pastures of green and yellow grass, comes into view. This country drains westward through Little Shasta River to Shasta Valley. From Pineland the road descends toward 
Mount Shasta, with the rugged cliffs of Sheep Rock on the right. These cliffs are composed of dark lavas and tuffs, which dip east.

Mount Shasta continues in sight for many miles. The most impressive view is obtained from the station called Mount Shasta. The mountain has two summits. The higher one, on the left $(14,380$ feet), is that of Mount Shasta proper; the lower one (12,433 feet) is Shastina. Whitney Glacier lies between the two peaks and is over 2 miles long. A prominent gray pile of bowlders and gravel, clearly in view at the lower end of the glacier, is its terminal moraine. Mount Shasta above a level of 4,000 feet is composed of lava, chiefly a kind containing less silica and generally lighter in color than basalt, known as andesite. There are a few basalt cones about the base of the mountain. Near milepost 364 are some light-gray hills known as the Haystacks, composed of sedimentary and intrusive rocks like those of the Klamath Mountains and forming, as it were, an island in the sea of lava.

About 5 miles beyond the Haystacks, on the right, is a steep little valley formed by a caved-in lava tunnel. When the supply of lava is cut off at the close of an eruption the molten interior of a flow continues to move down hill under its hardened crust, leaving tunnellike caves which may be a mile or more long.

Beyond this valley is a gravel deposit made by Whitney Creek, which is fed by Whitney Glacier. The creek has cut a deep canyon for several miles below the glacier, but before it reaches the point where the railroad crosses it the stream becomes overloaded with gravel and has to drop part of its load. In summer the creek disappears in the porous gravel deposit.

The flows of lava that once poured down the sides of Mount Shasta end in bluffs around which the railroad swings to Weed.

\section{MAIN LINE FROM MEDFORD SOUTHWARD.}

Southeast of Medford the valley narrows, and at Talent low foothills of Cretaceous rocks are close to the railroad. The gravels formerly worked in the placer mines seen along here on the

\section{Phoenix.}

Elevation 1,566 feet. Population 250.

Seattle 519 miles. right (southwest) are for the most part of Quaternary age. Some gold, however, has been obtained from a Cretaceous conglomerate whose pebbles were derived directly from the still older rocks on which the conglomerate rests. The best known of these placers are those of the Forty-nine group, near Phoenix, which have yielded not only much

Talent.

Population 863.* Seattle 521 miles. gold but also a number of Cretaceous fossils. The older rocks on which the Cretaceous conglomerate rests are possibly Paleozoic. Farther south, in the neighborhood of Ashland, these rocks are succeeded along the railroad by a granular igneous rock (quartz diorite) resembling granite. 
By looking ahead from a point near Ashland the traveler may see a bold rock, Pilot Knob, in the Siskiyou Mountains (a part of the Klamath Mountains). In early days this knob, which stands more than 6,000 feet above the sea, guided immigrants to the pass to California now utilized by the railroad.

Ashland, which passengers generally remember as the fresh-fruit station, is the center of a great peach country and took the prize for peaches at the Chicago Exposition. Pears also are Ashland.

Elevation 1,890 feet. Population 5,020 . Seattle 527 miles.

being increasingly grown in this region. Orchards are being rapidly extended southward and westward over the lower slopes of the mountains facing the morning sun. Behind them rise the forested spurs of the Siskiyou Mountains, culminating in Siskiyou Peak (7,662 feet) and Sterling Peak (7,377 feet), which carry snow as late as July.

Near Ashland the crumbling quartz diorite is well exposed, together with sandstones and shales of Cretaceous age. To the northeast rises Grizzly Peak (6,000 feet), a pile of lava flows, under which, as may be seen on the gentle slopes near Bear Creek, are sedimentary rocks that contain some beds of coal and fossil plants, probably. of Eocene age. The Eocene plants of the Cascade Range are described below by F. H. Knowlton. ${ }^{1}$

On leaving Ashland the train begins to climb the Siskiyou Mountains, which form the divide between the Rogue and Klamath river basins. The pass is 2,235 feet above Ashland and the ascent is made by a 3.3 per cent grade-that is, at the rate of 174.2 feet to the mile. This average grade is maintained for nearly 30 miles. Shales, sandstones, and conglomerates of Cretaceous age are exposed along the railroad for more than 10 miles beyond Ashland, except a short

${ }^{1}$ In the vicinity of Ashland and Medford, there has been found a fossil flora which is not only totally different from that of Jurassic time but is also different from the living flora of Oregon. That this flora is very unlike the Jurassic flora is not surprising in view of its much later age (probably upper Eocene, Tertiary), which makes it many millions of years youngerin fact, a thing of yesterday as geologic time is measured.

The Ashland fossil flora is a small one, comprising only about 15 forms belonging to perhaps 10 types. Among them is a small fern with delicate, deeply cut fronds. There is also a Sequoia of the same type as the famous redwood of the Coast Range and probably a direct ancestor of it, together with a pine of the wellknown white pine type, with its leaves in clusters of five. Among the dicotyledons or deciduous trees there is a wellmarked species of alder, a chestnut with the usual sharply toothed leaves, at least four kinds of oak, an elm, a opice bush (Benzoin), and a leaf that is doubtfully regarded as belonging to a fig.

A flora which is of the same type and hence presumably of about the wame age as this one is found in the rocks of northern California, especially about the big bend of Pit River and on Little Cow Creek east of Redding. These floras are evidently closely related to the plants that lived during the period wen certain of the gold-bearing gravels of the Sierra Nevada in California were being deposited. The geologic age of these gravels has been determined in part by the aid of the fossil plants. 
distance beyond milepost 442, where some of the underlying older (Paleozoic) rocks appear. The Cretaceous rocks continue beyond the first great curve in the railroad line to a point near milepost 416, where an intrusive mass of granodiorite appears and continues to Siskiyou, the summit station. Beyond the second great curve, at milepost 415 , there are good views of the valley left behind and of the Cascade Range.

At Siskiyou station the Pacific Highway, which crosses the summit farther east, near Pilot Knob, is near by on the left. Here on Sep-

\section{Siskiyou.}

Elevation 4,113 feet. Seattle 544 miles. tember 29, 1841, the Wilkes exploring party crossed the mountain, which was then the boundary between the United States and Mexico. Pilot Knob was named Emmons Peak by Wilkes, after the officer in charge of the party. At Siskiyou the railroad enters a tunnel 3,108 feet long, which passes about 500 feet below the summit. The rock near by is quartz diorite, and this is succeeded by a darker igneous rock (andesite) through which the tunnel has been driven and which, as will be seen farther south, is erupted through sediments of Cretaceous age. Soon after emerging from the tunnel into the drainage basin of Klamath River the traveler obtains his first view of Mount Shasta, one of the finest and most imposing of the snow-capped peaks of the Pacific coast. At milepost 410 Pilot Knob appears on the left (east).

At Colestin, about a mile beyond the end of the tunnel, a modest hostelry has been built near a good spring of effervescent chalybeate

Colestin, Oreg. Seattle 546 miles.
Elevation 3,675 feet.

water. With its mountain surroundings, a delightful summer climate, and good hunting, this place is likely to be more frequented as its attractions become known.

In the descent from Colestin to Hilt (Cole) and thence to Hornbrook the train passes almost continuous exposures of Cretaceous sedimentary beds cut at many places by intruded igneous rocks. Some at least of these igneous rocks are tilted and faulted as much as the sedimentary rocks and consequently may be older than most of the lavas of the Cascade Range, which, as a rule, lie in nearly horizontal attitudes.

Before reaching Cole station, at 403.2 miles from San Francisco, the railroad crosses the line between Oregon and California.

California, known as the Golden State, is next to the largest State in the Union. It is 780 miles in length and about 250 miles in average width and has a total area of 156,092 square miles, California. being nearly equal in size to New England, New York, and Pennsylvania combined. The population of California in 1910 was $2,377,549$, or about one-tenth that of the Eastern States named. The area covered by public-land surveys is 123,910 
square miles, or nearly 80 per cent of the State, and 21 per cent of the State was unappropriated and unreserved July 1, 1914.

Along the State's 1,000 miles of bold coast line there are comparatively few indentations. The bays of San Diego and San Francisco are excellent harbors, but they are exceptional.

The climate of California varies greatly from place to place. Along the coast in northern California it is moist and equable. Around San Francisco Bay a moderate rainfall is confined almost wholly to the winter, and the range in temperature is comparatively small. In parts of southern California typical desert conditions prevail. The great interior valley is characterized by moderate to scant winter rainfall and hot, dry summers. Snow rarely falls except in the high mountains, where - as, for example, in the Sierra Nevada-so much of it may accumulate as to interfere with railway traffic.

Forests cover 22 per cent of the area of the State and have been estimated to contain 200,000 million feet of timber. They are notable for the large size of their trees, especially for the huge dimensions attained by two species of redwood-Sequoia washingtoniana (or gigantea), the well-known "big tree" of the Sierra Nevada, and Sequoia sempervirens, the "big tree" of the Coast Range. Some of these giant trees fortunately have been preserved by the Government or through private generosity against the attacks of the lumberman. The 21 national forests in California have a total net area of 40,600 square miles, or about one-fourth of the State's area. The national parks in the State are Yosemite (1,124 square miles). Sequoia (252 square miles), and General Grant (4 square miles). The national monuments in the State are the Cabrillo, Cinder Cone, Devil Postpile, Lassen Peak, Muir Woods, and Pinnacles, and there are bird reserves at Klamath Lake, East Park, Farallon, and Clear Lake.

Agriculture is a large industry in California, and with the introduction of more intensive cultivation its importance is increasing rapidly. In the variety and value of its fruit crops California has no rival in the United States, if indeed in the world. Its products range from pineapples and other semitropical fruits in the south to pears, peaches, and plums in the north, but it is to oranges and other citrus fruits and to wine grapes that California owes its agricultural supremacy.

During the season from November 1, 1913, to October 31, 1914, California produced 48,548 carloads of citrus fruit, $42,473,000$ gallons of wine, and 12,450 tons of walnuts and almonds.

Of its mineral products, petroleum ranks first in total value and gold next. California's output of petroleum in 1914 was valued at $\$ 48,466,096$, about 25 per cent of the world's yield, and its output of gold in that year at about $\$ 21,000,000$. In the production of both petroleum and gold California leads all other States in the Union. 
California was formerly a part of Mexico but in 1848 was ceded to the United States, and on September 7, 1850, was admitted to the Union as a State. Its history is full of stirring and romantic episodes and should not be neglected by the visitor desirous of understanding the spirit of the land.

The same Cretaceous conglomerate seen at Ashland continues through the mountain and reappears near Hornbrook (see sheet 8 , Hornbrook, Cal.

Elevation 2,156 feet. p. 64), where it has been washed to some extent for gold. Directly ahead from Hornbrook may be seen Seattle 562 miles.

Black Mountain, whose summit is a mass of lava resting on Cretaceous strata that dip toward the east.

A few miles south of Hornbrook, at Klamathon, the railroad crosses Klamath River, which rises in the lake region east of the main ridge Klamathon. of the Cascade Range and is extensively utilized near Seattle 564 miles. its head for irrigation. Along the course of the Klamath through the Cascade and Coast ranges there are numerous power sites, and at some of these about 5,130 horsepower has already been developed. Klamath River has not the beautiful clearness of the Rogue and the Umpqua.

Passing Thrall, Ager, and Snowdon in succession the railroad climbs to a divide overlooking Shasta Valley and affording an excelAger.

lent view of Mount Shasta. In making this ascent it Elevation 2,335 feet. passes over a series of shales, tuffs, and lavas of Seattle 570 miles.

Miocene age in the order in which they were deposited. From Ager a stage line runs up Klamath River to Klamath Hot Springs, formerly known as Shovel Creek Springs, a resort noted for its fishing and mud baths. ${ }^{1}$

From Montague a short branch line runs to Yreka, near which in early days a number of placer mines and later a number of lode mines were successfully worked for gold. A short Montague.

Elevation 2,541 feet. distance south of Montague, near Shasta River, a Seattle 581 miles.

salt well was once operated but is now abandoned. The brine was obtained from the Cretaceous sandstone which underlies much of Shasta Valley.

\footnotetext{
1 The trip through the canyon affords a cross section of the greater portion of the Cascade Range, but, as in the Columbia River section, only lavas are to be seen. A small volcano which at some unknown date broke out in the canyon dammed the river with its lava. In the lake so formed there lived and died countless numbers of the microscopic plants known as diatoms-little organisms possessing siliceous

shells, or more properly skeletal parts, that fit together much like a pill box and its cover. The white or very light earth that may be seen along the stage road is composed almost entirely of these delicate siliceous skeletons, which when examined with a strong microscope are found to be of marvelous delicacy and beauty. This material, diatomaceous or infusorial earth, is used as a polishing or scouring agent.
} 
BULLETIN 614

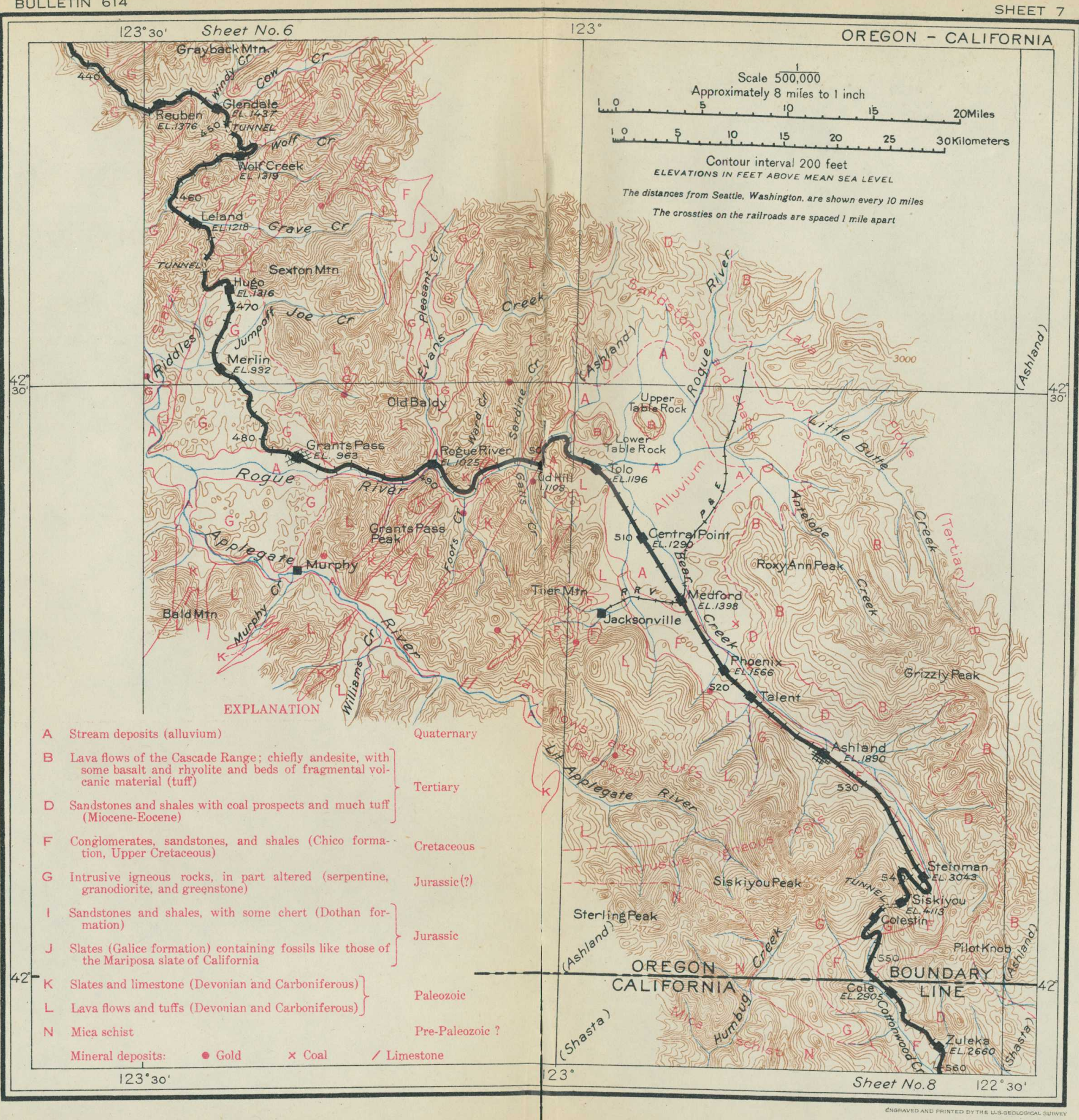


Scattered over Shasta Valley are many small knolls of lava and tuff, which appear to be, in part at least, the products of minor and local eruptions that broke through the Cretaceous beds, each vent contributing its little pile of material. Such feeble and diffuse volcanic activity is in marked contrast with the vigorous outbursts that built up the great cone of Shasta. On the right (west) as Gazelle is approached the traveler may trace along the hills the nearly horizontal line of the Yreka ditch, completed in 1856 to bring water to the rich placer mines near Yreka, but now used for irrigation near Gazelle.

Shasta Valley is devoted chiefly to stock raising, and about 700 carloads of cattle are shipped annually from Gazelle station. In a valley on the right (west); half a mile beyond Gazelle, Gazelle.

Elevation 2,758 feet. is exposed some gray limestone containing fossil Seattle 595 miles. shells of Devonian age. This and other fossilbearing limestones in the region afford evidence that strata of Paleozoic age lie under the Cretaceous rocks of Shasta Valley and form the mountains to the west. These strata are cut by many bodies of intrusive rock.

Crossing Shasta River the railroad leaves the dry plains and near Edgewood enters the wooded foothills northwest of Edgewood.

Elevation 2,953 feet. Population 2,257.* Seattle 603 miles.

Mount Shasta. These hills are apparently composed in large part of morainal material left by some vanished glacier. The road ascends Boles Creek to Weed, where the main line is joined by the branch that extends through Klamath Falls to Kirk, Oreg.

Weed is within the forest belt of Mount Shasta. Here are large sawmills which each day cut up about 125 carloads Weed.

Elevation 3,465 feet. Seattle 608 miles.

of logs, chiefly yellow and sugar pine, making 87,500 feet of lumber. Much of this is manufactured at Weed into doors, window sashes, and box shooks (boards cut to size, ready to be nailed).

On the left near the summit is Sugar Loaf (PI. XX, A, p. 62), a remarkable conical peak of solid lava (andesite) without any frag-

Summit.

mental material whatever in its make-up. The

Elevation 3,905 feet. thick pasty lava of which it is composed bulged up Seattle 611 miles. directly over the volcanic vent without explosive eruption. The andesite of Sugar Loaf is remarkable for its prominent black crystals of the mineral hornblende.

On the divide between Edgewood and Sisson is much loose stony material that consists largely of fragments of lava known to have come from the west slope of Mount Shasta. This deposit appears to be a moraine, left by a glacier that no longer exists. Its surface, like that of moraines in general, is hummocky and contains small basin-like hollows occupied by ponds or swamps. The western 
extension of this moraine abuts against the foothills of the Klamath Mountains. The meadows seen on the right (west) on the way down to Sisson probably represent a lake whose waters were held against the natural dam of the moraine. In course of time the lake was silted up and became a meadow. The morainal material, which is well exposed at Upton, is used for track ballast.

About $1 \frac{1}{2}$ miles north of Sisson (338 miles from San Francisco) a large spring may be seen to the west of the railroad. This is sometimes referred to as the source of Sacramento River, but the real head of the Sacramento is in the mountains about 7 miles southwest of this spring.

Mount Shasta (PI. XXI) stands out majestically from Sisson and Sisson.

Elevation 3,594 feet. may be ascended from this point. A good trail, about Seattle 619 miles. 6 miles in length, leads to Timberline camp, and from this camp the summit, 6,000 feet higher, may be reached and the return made to Sisson in a day.

That temperature and moisture control the distribution of plants and animals is well illustrated by the strong contrast between the

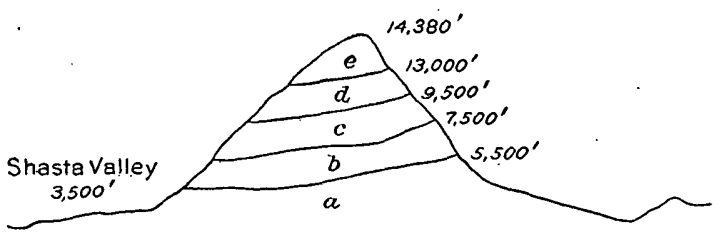

Figure 10.-Tree zones of Mount Shasta, Cal. a, Transition zone, yellow pine (Pinus ponderosa), sugar pine (Pinus lambertiana), and many others; $b$, Canadian zone, Shasta fir (Abies shastensis); $c$, Hudsonian zone, white-barked pine (Pinus albicaulis); $d$, alpine zone, Hulsea nana, extending up to 11,300 feet; $e$, zone above plant growth. The highest plants found are the Sierra alpine draba (Draba breweri) and Polemonium pulchellum, which occur at 13,000 feet. flora of Mount Sbasta and that of Shasta Valley. The summit of Shasta is bare of vegetation because of cold, and Shasta Valley, 10 miles away, is treeless for lack of moisture. Between these extremes lies the great forest belt of Mount Shasta, the trees of which are arranged in zones according to the requirements of each species for temperature and moisture. The tree zones as worked out by Dr. C. Hart Merriam are shown in simplified diagrammatic form in figure 10.

The extreme upper limit of plant growth is reached at an elevation of 13,000 feet. Among the animals that frequent the summit may be mentioned butterflies, hawks, and mice. Buck brush and manzanita make the undergrowth of the lumbered region, but the trees appear to be gaining on the underbrush in the struggle for existence.

The glaciers of Mount. Shasta are smaller than those of . Mount Rainier, and the charming upland meadows of the northern mountain are entirely lacking here. . The view from the summit, however, is unsurpassed by that from any cone in the Cascade Range. Although considered extinct, Mount Shasta still shows vestiges of volcanic activity. There is a sulphurous fumarole (an opening from which 


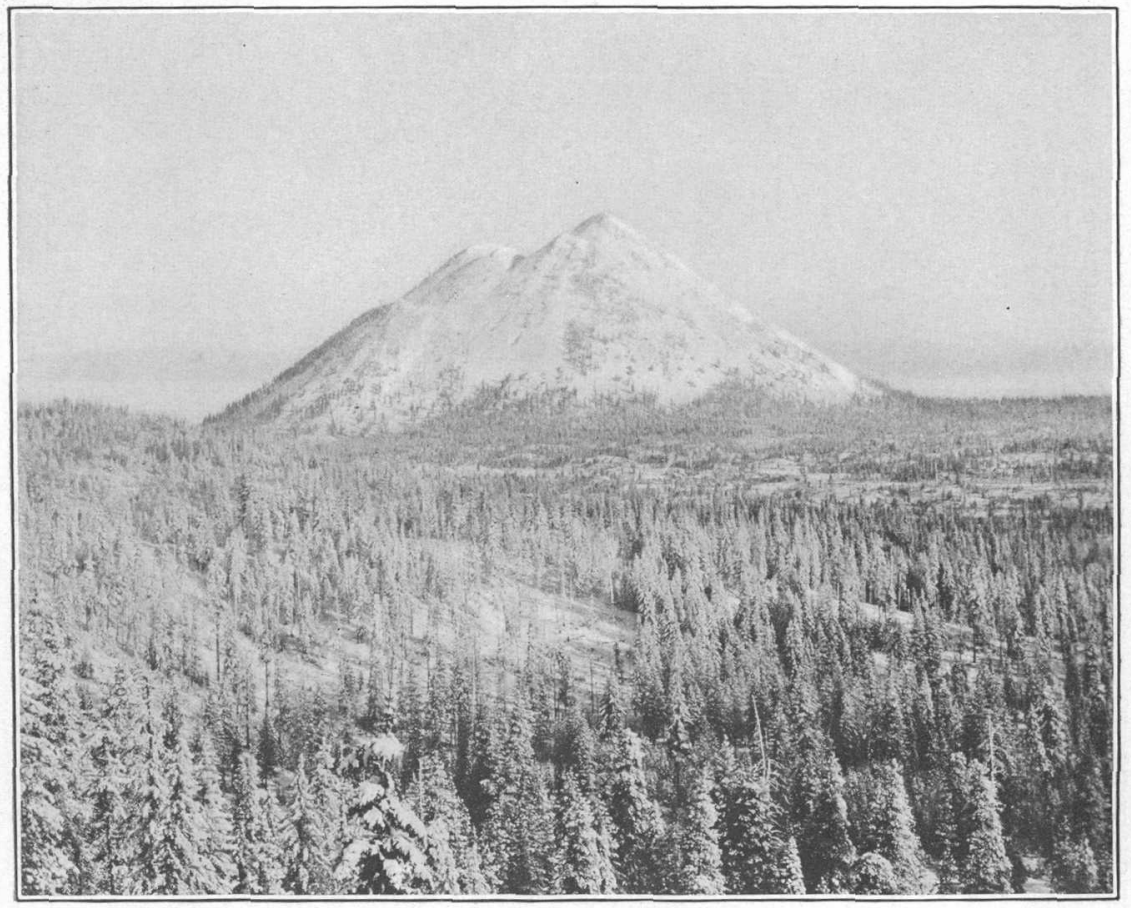

A. SUGAR LOAF, NEAR WEST BASE OF MOUNT SHASTA, CAL.

A lava cone without cinders in its make-up or a crater on its summit. Photograph by Weister Co., Portland.

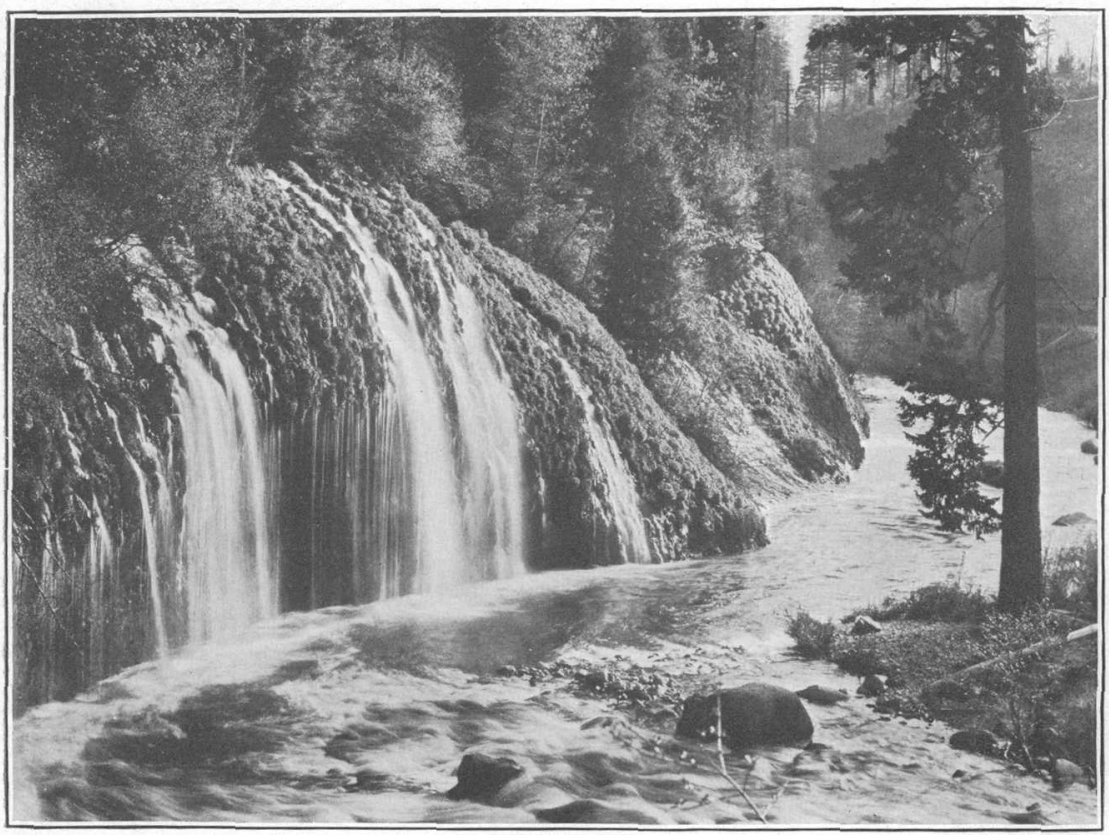

B. MOSS BRAE FALLS, NEAR SHASTA SPRINGS, CAL. 


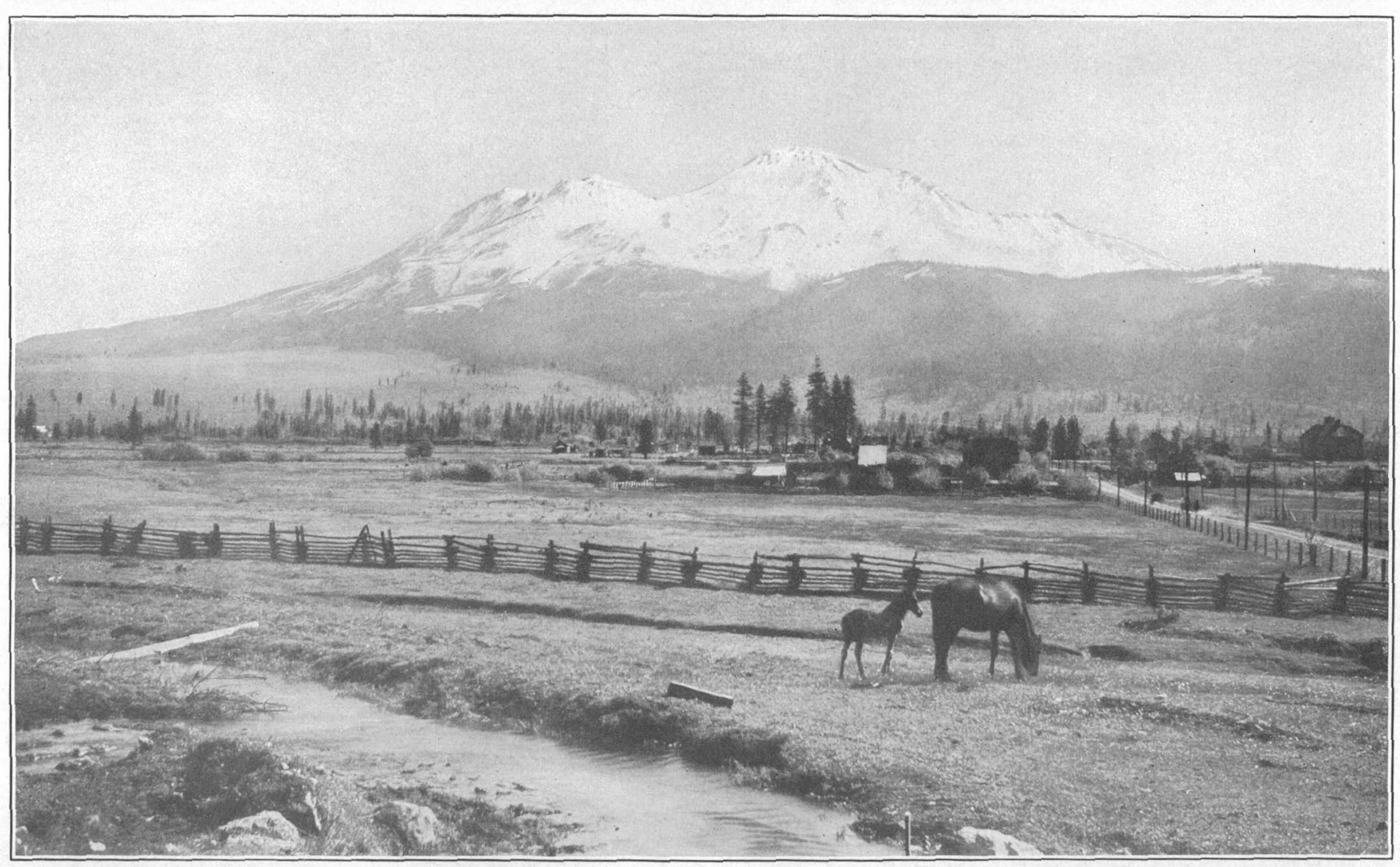

MOUNT SHASTA, FROM SISSON, CAL.

View after the first snowfall of autumn. Mount Shasta is a double volcano, consisting of Shastina, on the left, a id Shasta proper, on the right, 2,000 feet higher (elevation, 14,380 feet). 
hot gases issue) on its summit and another on its northern slope. During one of the later eruptions of Shasta a stream of lava (andesite) poured down its southern slope, entered the channel of the Sacramento, and followed that stream for 50 miles.

Below Mott the railroad makes a sharp bend and descends into the canyon of the Sacramento. For 75 miles this canyon traverses a spur of the Klamath Mountains that projects toward the Sierra Nevada. In the descent into the canyon there may be seen on the right (north) a continuous section of more than 300 feet of lavas and tuffs. At milepost 328 the railroad doubles on itself again and crosses the Sacramento, the first of 17 crossings between Sisson and Redding. The older rocks (Paleozoic and Mesozoic) of the Klamath Mountains appear here, and those most noticeable along this part of the route are serpentine and some related coarse-grained dark eruptive rocks.

The Shasta Springs yield a celebrated carbonated water containing a large percentage of iron and magnesia, which is bottled for market. The town and hotels are on a terrace 300 feet above the

Shasta Springs.

Elevation 2,538 feet: Seattle 630.6 miles. springs, which issue near the contact of the horizontal lavas with the underlying older rocks. Near the main spring is Oxone Spring, whose water is of an entirely different character and has a pungent odor.

A few hundred yards below Shasta Springs the train again crosses Sacramento River and passes the beautiful Moss Brae Falls (Pl. XX, $B$ ) on the left. Summer resorts are numerous in this vicinity. A short distance below Shasta Springs the lava, which, as previously described, at one time took possession of the channel of the river, forms both sides of the canyon cut by the Sacramento since it was so rudely ejected. A good example of columnar jointing may be seen in this lava on the right (west) side of the track, as the train nears Dunsmuir.

Dunsmuir is chiefly a railroad town. Good hunting and fishing are to be had near by, and in front of the station are two aquariums in which may be seen the varieties of trout found in Dunsmuir. the region. Three miles south of Dunsmuir, on LitElevation 2,284 feet. tle Castle Creek, is a chromite mine, which in 1913 Population 1,719. Seattle 634 miles.

was the only mine in the United States producing chromic iron ore. In 1914 there were several other but much smaller producers. At the crossing of Little Castle Creek, near milepost 319, the rugged pinnacles of Castle Rock appear on the right. Castle Crag, Castle Rock, and Castella are all neighboring summer resorts near the rugged peaks that suggested their names. At Castle Rock there are effervescent (carbonic acid) springs, the water from which is bottled near the mouth of Soda Creek. This place was a noted station on the old Oregon-California stage line. 
Soda Creek drains an area of Paleozoic slates and limestones east of Sacramento River.

From Castella a trail runs west across the Trinity Mountains to Cinnabar, where quicksilver ore has been found. Serpentine and related dark igneous rocks. (pyroxenite and gabbro)

Castella.

Elevation 1,904 feet.

Seattle 641 miles. are the principal rocks along the railroad near Castella and in the mountains to the west. In places these rocks have been rendered slaty by enormous pressure. The narrow mass of Shasta lava through which Sacramento River is cutting forms low benches at many places along the sides of the canyon. Between Castella and milepost 311, 2 miles north of Sims, the river has not yet worn down into the older rocks, and consequently the lava appears in the bed of the stream.

Sims, near the mouth of Hazel Creek, which enters the Sacramento from the east, is frequented by trout fishermen, the upper Sacra-

Sims. mento affording excellent sport with the fly. Some Elevation 1,679 feet. Seattle 647 miles. asbestos occurs in the serpentine west of the station. Near milepost 307 the railroad crosses Shotgun Creek, on which chromite was mined a few years ago.

The scenery along the Sacramento Canyon from Shasta Springs to Redding is varied and charming. In places the river is narrowly confined between steep slopes 2,000 feet in height. Elsewhere the valley opens and little farms are perched on the hillside benches. All the slopes are well wooded, for although lumbermen have come and gone the country is rapidly being reforested and daily grows more attractive. The clear rushing Sacramento, here foaming over bowlders, there flashing more quietly under the large leaves of the water saxifrage (Peltiphyllum peltatum), which grows in beautiful masses along the water's edge, is a stream to delight the heart of a fisherman. Along it may be seen the expert with the fly wielding his delicate tackle, in contrast with the Indian under his tentlike shelter, waiting, spear in hand, for the unsuspecting salmon.

A mile below Gibson (see sheet 9, p. 70), at milepost 303, igneous rocks are succeeded by slates and sandstones (the Bragdon formation) of Carboniferous age. These continue with few interruptions for nearly 20 miles.

Good exposures of slate appear as Lamoine station is approached, and terraces, remnants of the lava flow from Shasta, Lamoine.

Elevation 1,300 feet. Seattle 656 miles. may be seen on both sides of the river. About 75,000 feet of lumber, of which one-third is obtained from the adjacent Shasta National Forest, is cut daily at Lamoine. About half of this lumber is manufactured locally into boxes. 


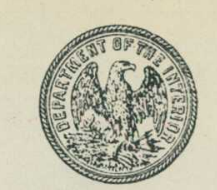

GEOLOGIC AND TOPOGRAPHIC MAP оғ тHE

\section{SHASTA ROUTE}

From Seattle, Washington, to San Francisco, California Base compiled from United States Geological Survey Atlas Sheets, from railroad alignments and profiles supplied by

the Southern Pacific Company and from additional inform
tion collected with the assistance of this company

UNITED STATES GEOLOGICAL SURVEY GEORGE OTIS SMITH, DIRECTOR

David White, Chief Geologist $\quad$ R. B. Marshall, Chief Geographer 1915

Each quadrangle shown on the map with a name in parenthesis in the
lower left corner is mapped in detail on the U. S. Q. S. Topographic Sheet of that name.

EXPLANATION

Lava fows of the Cascade Range, chiefly andesite,
including Sacramento River flow, with some basalt
and rhyolite and beds of fragmental volcanic material (tuffs) Sandstones and shales containing some coal; lava flows
and much tuff (Miocene-Eocene)

Conglomerates, sandstones, and shales containing fossils
(Chico formation, Upper Cretaceous)

Chiefly altered intrusive rocks (serpentine and gabbro
and some altered lavas (greenstones)

$\left.\begin{array}{l}\text { Shale (Brock shale) and limestone (Hosse'kus limestone) } \\ \text { underlain by thin-bedded sandstones, shales, and tuffs }\end{array}\right\}$ Triassic

Tuffs (Nosoni) and limestone (McCloud) of Pennsylvanian age, underlain by tuf
(Baird) of Mississippian age

Thin-bedded sandstones, shales, and conglomerates, with
pebbles containing Devoronian fossils (Bragdon forma-
tion, of Mississippian agee)

Sandstones, slates, and limestones, in part at least

Mica schists with ancient lavas and intrusive igneous Tertiary

\section{Cretaceous}

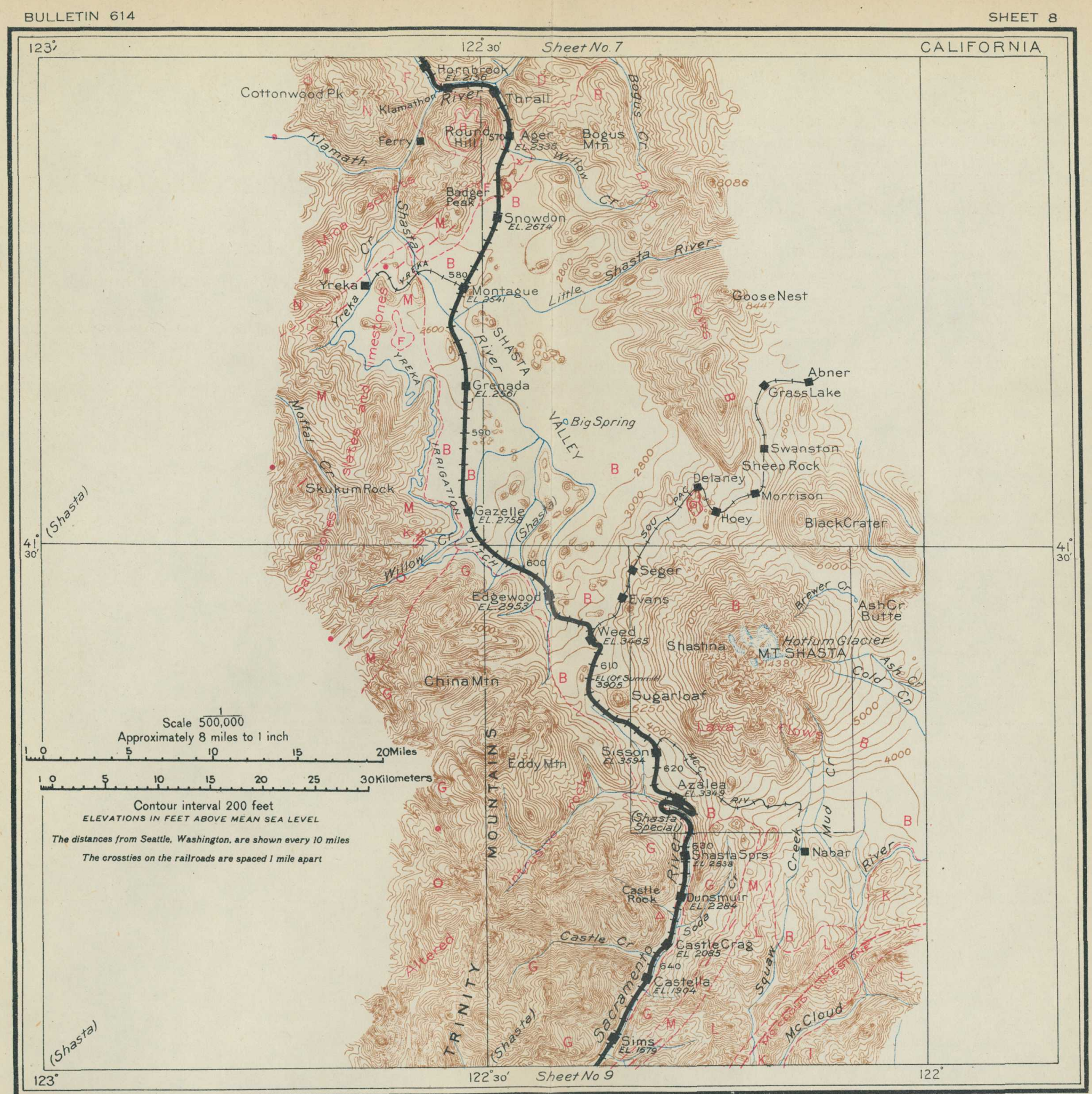


Near Delta the Bragdon slates make rugged slopes and the forest growth becomes scanty. The light-colored digger pine (Pinus sabiniana), with its strangely thin foliage and unpinelike

Delta.

Elevation 1,137 feet. Population 2,786.

Seattle 659 miles. habit of branching, becomes prominent. Associated with it are live oaks, buckeyes, and shrubs characteristic of lower altitudes and drier climate than those of the country about Mount Shasta. From Delta stages run west over the mountain to Trinity Center and Carrville, where gold is won from both placer and lode mines.

Half a mile below Delta, on the right (southwest), is a bluff of slate overlain by 10 feet of gold-bearing gravel deposited by the river when its bed was about 70 feet higher than now. The gravel is covered by the lava from Mount Shasta, as illustrated in figure 11. Since the lava flowed down the canyon the river has cut not only through the lava and gravel but 60 feet into the slates.

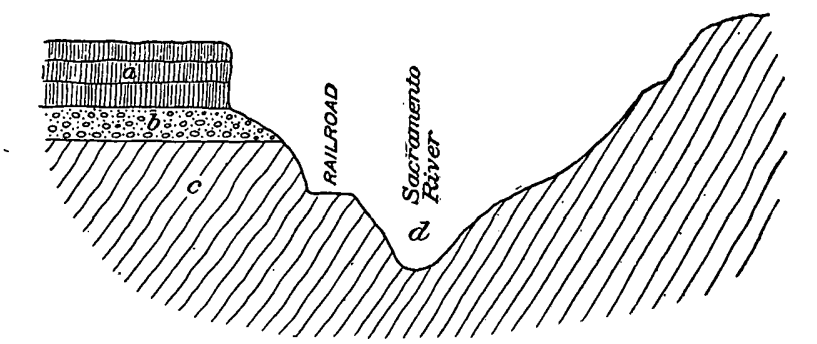

Figure 11.-Section of canyon of Sacramento River just below Delta, Cal. a, Terrace formed by remnant of lava stream that flowed down the canyon of the Sacramento from Mount Shasta to a point 10 miles south of Delta; $b$, ancient gravel bed of the Sacramento covered by the lava flow from Mount Shasta (gravel is auriferous); $c$, slates of Carboniferous age in which the canyon is cut; $d$, portion of the canyon ( 70 feet) cut by the river since the lava flowed from Mount Shasta.

The old California-Oregon wagon road crosses the river and railroad at Antler (Smitbson), and the Pacific Highway crosses about 2 miles farther south. Near milepost 287 the lava flow Antler.

Elevation 974 feet. Seattle 665 miles.

from Mount Shasta ends. Its entire length is about 50 miles. Here the railroad crosses the river and goes through a tunnel.

Between some of the beds of slate and sandstone, which are well exposed along this part of the route, are beds of lighter-colored gray conglomerate, generally less than 10 feet thick. Most of Elmore.

Elevation 804 feet. Seattle 672 miles. the pebbles are flinty, but many. of them consist of fossiliferous limestone. These limestone pebbles, after long exposure to the weather, dissolve away, leaving holes that can be seen from the train. The coarsest conglomerates of the Bragdon formation, to which all these rocks belong, occur near Elmore, where the limestone pebbles contain Devonian fossils. The occurrence of these pebbles shows that the Devonian rocks (Kennett 
formation) were subjected to erosion and that fragments of them were rounded into pebbles by waves or streams before the overlying Carboniferous (Bragdon) formation was deposited. In geologic language the Bragdon formation rests unconformably on the slates, cherts, and limestones which make up the Kennett formation. The passage from the Bragdon formation to the Kennett formation is near a point 280.7 miles from San Francisco, but the unconformity can not be seen from the train. The Kennett formation is succeeded on the south by igneous rocks-a light-colored quartz porphyry and a greenish lava (meta-andesite--that is, altered andesite). These two rocks are closely connected with the occurrence of the large copper deposits of Shasta County. The altered andesite is older than the Kennett formation and represents volcanic action in early Paleozoic time. 'The porphyry is intrusive and was probably injected into the rocks with which it is associated in late Jurassic time. From this locality to Redding, a distance of about 20 miles, these are almost the only rocks visible along the railroad.

Pitt station is near the mouth of Pit River, where that stream joins the much smaller Sacramento. A branch railroad on the left (east) leads to Heroult, where there is an extensive deposit Pitt.

Elevation 688 feet. Seattle 678 miles. of iron ore and an electric smelter, and to Copper City and Bully Hill, where there are large copper mines.

A mile beyond Pitt is tunnel No. 2, at the farther end of which, on the right (west), there is exposed a narrow north-south belt of Devonian slates (Kennett formation). This belt lies in a large area of meta-andesite. It probably represents material which once lay horizontally on top of the andesite but which, when the rocks were bent into sags and arches by regional pressure-folded, as geologists say-was caught in a sag (syncline) and finally squeezed together as a narrow slate belt between two masses of meta-andesite.

Kennett is the northernmost of the three active centers of copper mining in Shasta County, and the Mammoth mine is about 3 miles

Kennett. northwest of the town. The ore of this region is Elevation 670 feet. Seattle 680 miles. pyritic and occurs as large bodies of irregular shape in the quartz porphyry referred to above. The fumes from the smelter are treated by the bag process before they are allowed to escape into the open air. By this means some of the zinc in the ore is saved in the form of zinc sulphate, a white pigment.

Fossil-bearing limestone belonging to the Kennett formation (Devonian) caps the ridges on both sides of Backbone Creek. Lime and ground limestone, used as a fertilizer, are both made bere. 
A belt of country in Shasta County, extending 25 miles northeastward from Kennett, is especially noted for its Devonian, Carboniferous, Triassic, and Jurassic fossils. ${ }^{1}$

On leaving Kennett the train crosses Backbone Creek. Here limekilns may be seen on the right (north), and a copper smelter is farther up the creek, behind them. From Kennett southward for many miles the railroad traverses a region of desolation. The fumes from the copper smelters at Coram, Kennett, and Keswick have killed all vegetation and left bare slopes whose coloring suggests the sun-baked hills of the desert. The principal copper mines are in the hills of porphyry to the right (west). To the left, across the river, is the meta-andesite, which contains numerous gold quartz veins.

The Balaklala copper mine is 3 miles northwest of Coram, west of the hills, and the smelter is at South Coram, a mile from the station. Across the Sacramento, opposite Motion, formerly

\section{Coram.}

Elevation 630 feet. Jopulation 666 . Seattle 684 miles. called Copley, a bench or terrace may be discerned about 200 feet above the river. This is cut in rock and is the work of the river at a former period of its history. It may be traced from this place into the

${ }^{1}$ On McCloud River, which flows into the Pit about 6 miles east of Kennett, there are in the McCloud limestone a number of Pleistocene caverns which contain animal remains of considerable scientific interest, described by $\mathrm{J}$. C. Merriam. In Potter Creek Cave, about 2 miles above the mouth of the McCloud, fossil remains of more than 50 species of animals were found in deposits on the floor. Approximately half of the total number of species were extinct. Among the animals represented in this cave were the great extinct cave bear, another bear more nearly related to the living black bear, a large extinct lion, a puma, an extinct wolf, and fragmentary specimens representing the mountain goat, deer, bison, camel, ground sloth, elephant, mastodon, an extinct horse, and a peculiar goatlike animal known as Euceratherium.

Samwel Cave, which is about 18 miles from the mouth of the McCloud, is a large cavern with many galleries, in several of which the cave earth contains remains of extinct animals. Among these is another peculiar extinct goatlike animal, known as Preptoceras.
The beautifully coiled and intricately marked fossil shells known as ammonites are especially abundant in the Triassic rocks of this region, and the Upper Triassic Hosselkus limestone of the region contains numerous remains of marine reptiles. Bones have been found representing the ichthyosaurs (fish lizards) and another peculiar marine group, the thalattosaurs (sea lizards). Numerous fragments have been obtained from these deposits, but the skeletons are nearly all imperfect and do not show the wonderful preservation of the Middle Triassic specimens from Nevada.

The history of the ichthyosaurs found in the Middle and Upper Triassic of the western region presents one of the most interesting studies of evolution thus far known in the story of this group. The Middle Triassic forms are much more primitive in every respect than those of the following Jurassic period and show less advanced specialization of the limbs: tail, eyes, and teeth for life on the high seas. The Upper Tricssic types also are relatively primitive but are intermediate between the Middle Triassic and the Jurassic stages of evolution. 
north end of the Sacramento Valley. At Buckeye, 4 miles north of Redding and about 3 miles east of the railroad, rich gold-bearing graviels, left by the river on this bench, were formerly worked.

Gold-bearing quartz veins are worked at the Reed Central Mine. mine, on the left (east) across the river from Central Seattle 690 miles. Mine station. The ore is brought to the railroad by a bucket tramway.

The Iron Mountain mine, which has produced copper to the value of over $\$ 33,000,000$, is 5 miles northwest of Keswick, with which it is connected by a very crooked narrow-gage railway.

Keswick.

Elevation 567 feet. Population $1,437 . * 1$ Seattle 692 miles. The ore of this mine is pyritic and, although of low grade, contains considerable gold and silver. It is smelted near Martinez, on San Francisco Bay, where part of the sulphur from the pyrite is manufactured into sulphuric acid. The acid in turn is used for converting rock phosphate into fertilizer.

At Keswick the rock terrace 200 feet above Sacramento River, first noted at Motion, is visible along both banks of the river. On the west side some patches of gravel lie on the terrace.

Middle Creek, which is crossed near the station of the same name, was at one time rich in placer gold, and dredges may be seen in Sacramento River below, recovering from the river Middle Creek.

Elevation 526 feet. Seattle 695 miles. gravels gold that probably came in large part from this creek. The rocky ledges along the river here are meta-andesite. In this vicinity the canyon of the Sacramento opens out into the wider valley that forms a part of the Great Valley of California. This wider portion is the area generally called the Sacramento Valley and is described below from data furnished by Kirk Bryan. ${ }^{2}$ A mile and a quarter beyond Middle Creek

\footnotetext{
${ }^{1}$ Including Coram and other places.

2 The Sacramento Valley extends from the vicinity of Redding on the north to Carquinez Straits on the south. It is a broad, flat plain 160 miles long, 50 miles wide at the south, and tapering gradually to about 20 miles in width near Redding. The valley is 557 feet above the sea at Redding and slopes down to sea level at Suisun Bay.

The area of the valley is about 6,500 square miles, of which $2,633,000$ acres, nearly two-thirds-is bottom land. On the east side of Sacramento River 535,000 acres and on the west side 424,500 acres, or 959,000 acres in all, is now subject to occasional overflow. Of this land more than 300,000 acres is protected by dikes.
}

The total irrigable area, including the rolling land lying north of Red Bluff, is $2,500,000$ acres, of which 123,500 acres was irrigated in 1912.

The principal tributaries of the Sacramento are Feather, American, and Mokelumne rivers, which rise in the Sierra Nevada. In the flatter parts of the valley overflow at some point is a yearly occurrence. The overflowed lands, which in many places support a luxuriant swamp vegetation, are among the most fertile in the valley, and levees have been built to reclaim them.

For five months, October to March, the weather is cool and rainy, but the rest of the year is practically rainless. Summer temperatures are high, reaching $115^{\circ} \mathrm{F}$, 
the river cuts through fossiliferous Upper Cretaceous (Chico) sandstone and conglomerate. These rocks unconformably overlap the older rocks of the Klamath Mountains, including the meta-andesite. On the right the bluff affords a section of the sands and gravels of the Red Bluff formation, which occupies a large area in the Sacramento Valley.

but the nights are cool and the air dry. The winter temperature seldom falls below freezing, and $18^{\circ}$ above zero is the lowest temperature recorded in 60 years. Snow is almost unknown:

The character of the climate is reflected in the life of the people. With the beginning of the rains in the fall grass springs up and cattle and sheep are brought down from the mountains where they have passed the summer. The overflowed tule lands in the center of the valley are grazed in the long dry summer, but with the coming of the rains the cattle are taken to the higher plains. The grain farmer sows his wheat and barley in the fall and harvests them early in the summer. He lets his land lie fallow after the rains, to be planted dry in the fall. All the deciduous fruits bear heavily and are rarely damaged by frost. The more delicate fruits and nuts-apricots, almonds, walnuts, olives, lemons, and oranges-grow well when assisted by irrigation. There are large areas of vineyards and the long dry season is favorable to the concentration of sugar in the grape and to the drying of the grapes to make raisins.

The agricultural character of the valley is closely related to its geologic history. With the uplift of the Sierra Nevada and Coast Range in Pliocene time the valley became land, and deposition of alluvial materials began under conditions similar to those of the present time.

The alluvium is of two kinds-an older and a younger. The older alluvium is of Pleistocene or possibly of late Pliocene age and rests on the eroded edges of Miocene and older rocks. It is composed of clay, sand, and gravel and varies much in appearance and composition. It is distinguished from the younger alluvium by the fact that it is now undergoing dissection by streams and by the greater oxidation and dehydration of its iron con- tent. Because of this oxidation it is characteristically red.

The deposition of the older alluvium was followed by uplift in both the Sierra Nevada and the Coast Range. The edges of the valley were bent up and the middle gently bowed down. In consequence of this movement the older alluvium was uplifted along the borders of the valley, and streams began to cut in to it. At this time began the deposition of the younger alluvium, which has continued to the present day. This material floors by far the larger part of the valley and is as varied in character as the older alluvium. The deposits are comparatively thin, probably nowhere in the valley over 300 to 400 feet thick. Every high water adds to them, and this is so well understood that farmers have been known to deliberately turn flood waters on their land for the benefit derived from the sediment left behind.

The recent alluvium is the most productive water bearer of the valley formations, largely because its gravels and sands are uncemented and porous. The water usually lies within 25 feet of the surface, but its level fluctuates with the seasons. This fluctuation is seldom more than 10 to 15 feet, a fact which indicates that a much larger volume of water is available than is at present utilized.

The Sacramento Valley is now in a state of rapid change. The overflowed lands are being divided into large districts for reclamation by levees and drainage. After reclamation they are cut up into small lots and colonized. Grain ranches are being subdivided and sold in small irrigated tracts. In consequence the population is increasing and its character is changing. The keen, intelligentirrigator, raising special crops, living a community life, and keeping abreast of the times, is replacing the old-time rancher. 
Redding, the seat of Shasta County, is the supply point for much of the southern part of the Klamath Mountains, especially the region drained by Trinity River and about Weaverville, a Redding.

Elevation 557 feet. Population 3,572. Seattle 698 miles. town 50 miles from Redding, reached by a daily automobile stage. The basin in which Weaverville stands has been the richest and most persistently productive gold-placer region of northern California. At the La Grange mine, reported to be the largest hydraulic mine in the world, about 1,000 cubic yards of gravel is washed each hour. A stage line runs eastward from Redding across the low Cascade Range north of Lassen Peak to Alturas, which is within the Great Basin, east of the Pacific coast mountain belt.

Redding is built on the division of the older alluvium of Sacramento Valley that has been named the Red Bluff formation. The railroad cuts in the plain south of the town show much coarse gravel belonging to this formation. To the west the gravel laps up over a terrace that is traceable around the northwest border of the Sacramento Valley and is continuous with the terrace along the river above Redding, already noted. Beyond the terrace may be seen to the northwest the rounded form of Bally Mountain (6,246 feet), composed of granodiorite, and in the west the sharper form of Bully Choop (7,073 feet), composed of peridotite.

At milepost 253 the railroad crosses Clear Creek, which drains the French Gulch mining district and on which is Horsetown, noted for its formerly active placer mines and for its Lower Cretaceous fossils. To the northeast the horizon shows the outlines of the numerous conical volcanic hills characteristic of this part of the Cascade Range. The highest of them is Lassen Peak (10,437 feet), an active volcano recently in eruption. To the left, farther north, is Crater Peak $(8,724$ feet), on which snow remains into July. The Lassen Peak volcanic ridge fills the 50-mile gap between the Klamath Mountains and the Sierra Nevada.

From Anderson a short railroad line runs northward to Bella-

\section{Anderson.} Population 1,801.* Seattle 709 miles.

\section{Panorama Point.}

Seattle 713 miles.

\section{Cottonwood.}

Elevation 423 feet. Population 439.* Seattle 716 miles.
Elevation 433 feet. vista. Directly east of Anderson is Shingletown Butte, a perfect little extinct volcanic cone. From Panorama Point may be obtained the best view of Lassen Peak to be had from the railroad. Shingletown Butte is in the foreground, and Inskip Hill, a group of recent craters, lies to the right (south) of it.

A quarter of a mile south of Cottonwood station the railroad crosses Cottonwood Creek, on which, 14 miles to the west, are some peculiar sandstone dikes. Here cracks in the rocks that were formed by an ancient earthquake have been filled with sand, and the sand filling has hardened into rock, so that the dikes resemble true igneous dikes. 
BULLETIN 614

SHEET 9

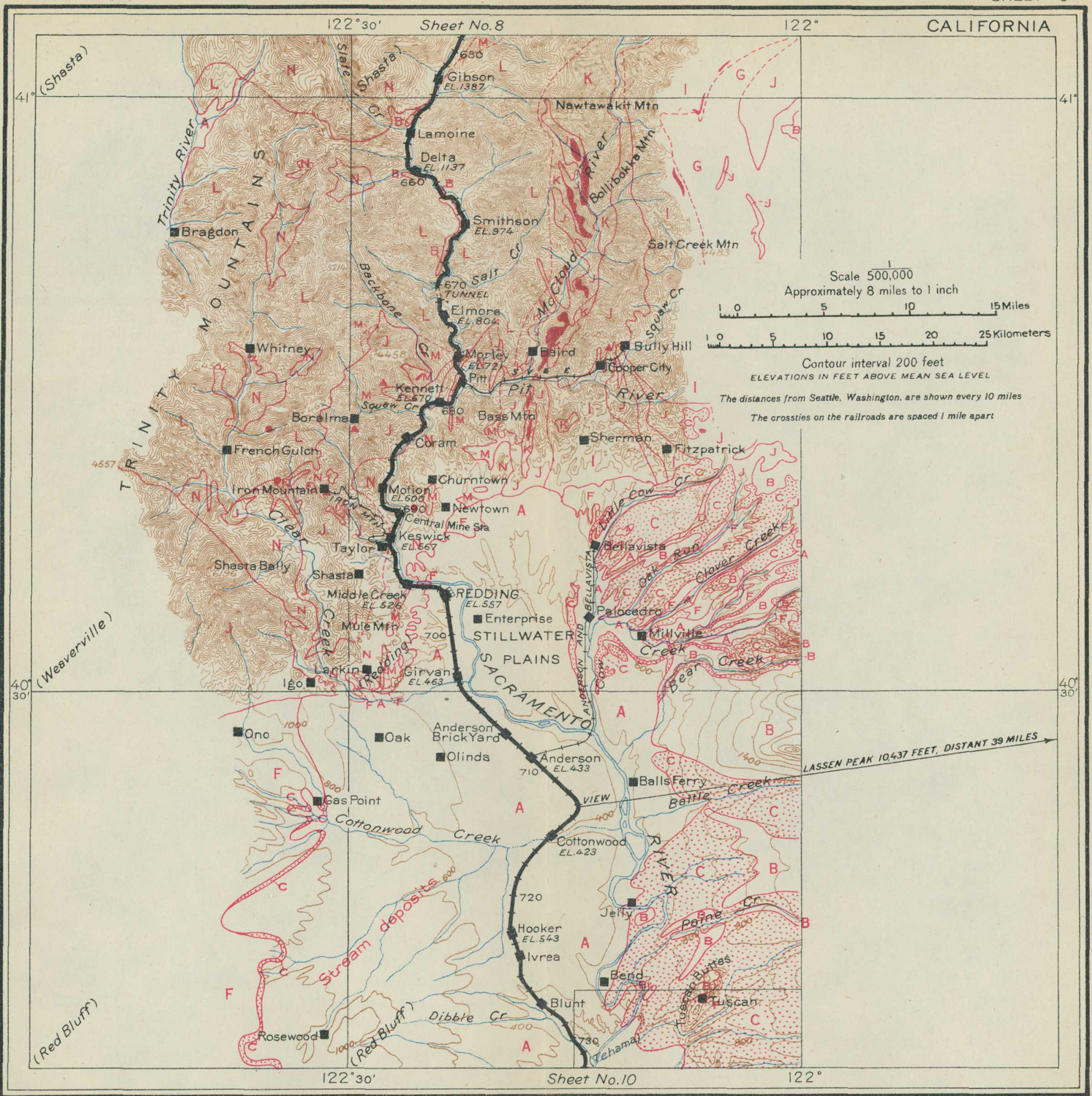




\section{GEOLOGIC AND TOPOGRAPHIC MAP}

OF THE

\section{SHASTA ROUTE}

\section{From Seattle, Washington, to San Francisco, California}

Base compiled from United States Geological Survey Atlas Sheets, from railroad alignments and profiles supplied by the Southern Pacific Company and from additional information collected with the assistance of this company

\section{UNITED STATES GEOLOGICAL SURVEY}

\section{GEORGE OTIS SMITH, DIRECTOR}

David White, Chief Geologist

R. B. Marshall, Chief Geographer

\section{5}

Each quadrangle shown on the map with a name in parenthesis in the lower left corner is mapped in detail on the U. S. G. S. Topographic Sheet of that name.

\section{EXPLANATION}

A Stream deposits (alluvium and Red Bluff formation) . Quaternary

B Lava flows (chiefly basait) east of the Sacramento) Valley and andesite in the upper Sacramento Canyon, flow from Mount Shasta

C Tuffs (Tuscan tuff, Pliocene); gravels, sands. and clays (Ione formation, Eocene) (stippled pattern)

F Conglomerates, sandstones, and shales; (Chico. Horsetown, and Knoxville formations) containing Cretaceous fossils

G Sandstones and shales composed largely of volcanic material (Potem and Modin formations), containing Jurassic fossils

I Shale (Brock shale) and limestone (Hosselkus limestone) underlain by thin-bedded sandstones, shales, and tuffs (Pit formation)

J Lavas, tuffs, and granular intrusive rocks of Triassic to Cretaceous age

Tertiary

Cretaceous

Jurassic

Triassic

Mesozoic

$K$ Tuffs (Nosoni) and limestone (BfcCloud) of Pennsylvanian age, underlain by tuffs, sandstone, and shale (Baird) of Mississippian age

$L$ Thin-bedded sandstones, shales, and conglomerate: pebbles contain Devonian fossils (Bragdon formation, of Mississippian age)

M Sandstone, shales, and limestone (Kennett formation)

Devonian

N Altered lavas and tuffs (meta-andesite)

Pre-Devonian

Mineral deposits:

o Gold predominant

$\triangle$ Copper predominant

$\Delta$ Chromium and iron predominant Limestone; represented by solid red color 
At milepost 236 may be had a view of the North and South Yolla Bolly Mountains, on the right (west), with snowbanks lasting into July. Toms Head is between them. These peaks are at the south end of the Klamath Mountains. Beyond and to the left of them is the Coast Range of California.

A low, broad uplift of the Quaternary formations, the Red Bluff arch, runs in an easterly direction across the northern portion of the

Hooker.

Sacramento Valley. The railroad crosses this arch

Elevation 543 feet

Seattle 722 miles. through cuts in gravel near Hooker, and Sacramento

River crosses it farther east, in Iron Canyon. The possibility of damming the river here affords the basis of an extensive project for irrigating 400,000 acres in Tehama County. Beyond Hooker the train passes Ivrea and Blunt.

Red Bluff (see sheet 10, p. 74), a thriving town, is the seat of Tehama County. It takes its name from the adjacent river bluff, about 50 feet high; in which is exposed a fine section

Red Bluff. of the sands and gravels of the older alluvium (Red Elevation 308 feet. Bluff formation), bowed up by the Red Bluff arch. Population 3,530. Seattle 733 miles.

The town is the head of navigation on Sacramento River and a supply point for a large area of farming and stock country. It is at the northern limit of the citrus belt, and oranges, lemons, almonds, and figs are raised here, but more attention is paid to peaches, pears, and prunes.

The Lassen Peak region and the great volcanic plain west of it may be most easily reached from Red Bluff during the summer by automobile or stage to Mineral, Morgan Springs, or Side trip to Las-
sen Peak and Cinder Cone.

Drakesbad, by way of the Red Bluff-Susanville stage road. From these places trails lead to the mountain. The trail from Mineral passes Soupan Hot Springs and the boiling mud pots and sulphur-lined fumaroles at the head of Mill Creek. At Morgan Springs there are hot-spring baths, and the trail from this place passes Bumpass Hell, a vigorous solfatara. Near Drakesbad are the Geyser, a large boiling spring; Tartarus Lake, a boiling mud lake of 3 acres, encircled by fumaroles and boiling springs; and the Devil's Kitchen, an area of solfataras. Warner Creek runs directly through the Devil's Kitchen, so that a fisherman may catch and cook his fish from the same stand. Cinder Cone, the work of a recent volcanic eruption, is within a day's reach. It has been made a national monument.

Lassen Peak, from which since May 30, 1914, there have been many. eruptions, may be easily reached by trail from Drakesbad. The character. of its outbursts is shown in Plate XXII (p. 72), and its new crater in Plate XXIII. The enormous rolling cloud which rises above the crater during an eruption and which is plainly visible from the railroad is composed of rock fragments, rock dust, and steam, 
with perhaps other gases. No fresh lava has issued from the crater. The dust and fragments blown out by the explosive action of the hot gases are derived from the older solid lava through which these gases have burst their way. The opportunity to observe a vigorous volcanic eruption in safety from a railroad train is itself a rare one, and the obstacles to a nearer approach need daunt no one who is willing to travel by stage and put up with simple accommodations. Drakesbad may be reached by automobile not only from the west by way of Red Bluff but also from the east by way of Westwood, on the Southern Pacific, or Keddie, on the Western Pacific.

Tuscan Springs, a health resort 9 miles northeast of Red Bluff, may be reached by daily stage. The springs, which are hot, rise in a. small area of Upper Cretaceous shales (Chico) surrounded by a large mass of volcanic tuff thrown out from the volcanoes of the Lassen Peak region.

At Proberta the railroad approaches the top of the bluff which limits the flood plain of the Sacramento on the west. The route

\section{Proberta.} continues along the bluff to Gerber. The Kimball Seattle 740 miles. Plains, about 12 miles wide, lie to the right (west). be be seen hop and alfalfa fields irrigated by water pumped from wells.

Gerber will soon succeed Red Bluff as the division point for this portion of the route. Here the train descends into the river bot-

\section{Gerber.} toms and, passing through green alfalfa fields, crosses Seattle 741 miles. Elder Creek before entering Tehama. On Elder Creek, about 20 miles west of this point, is exposed a famous section of Cretaceous rocks 29,000 feet in thickness. This great body of Cretaceous strata is inclined eastward, extending beneath the later formations that fill the Sacramento Valley on the east and lapping up against the Coast Range, which is made up mainly of older rocks on the west. The tilted Cretaceous rocks are beveled by erosion, and their edges form a broad terrace or plain along the western border of the Sacramento Valley at the foot of the Coast Range.

The town of Tehama is about half a mile east of the railroad station and is the oldest settlement in the county. The soil hereabouts is rich, but the country is occasionally overflowed. A

\section{Tehama.}

Elevation 223 feet. Population 221. Seattle 744 miles. in California. Tehama is on the later alluvium, but beyond it the line ascends again to the gravel plain of the reddish older alluvium. From Tehama the Marysville line turns off to the left, crosses the 


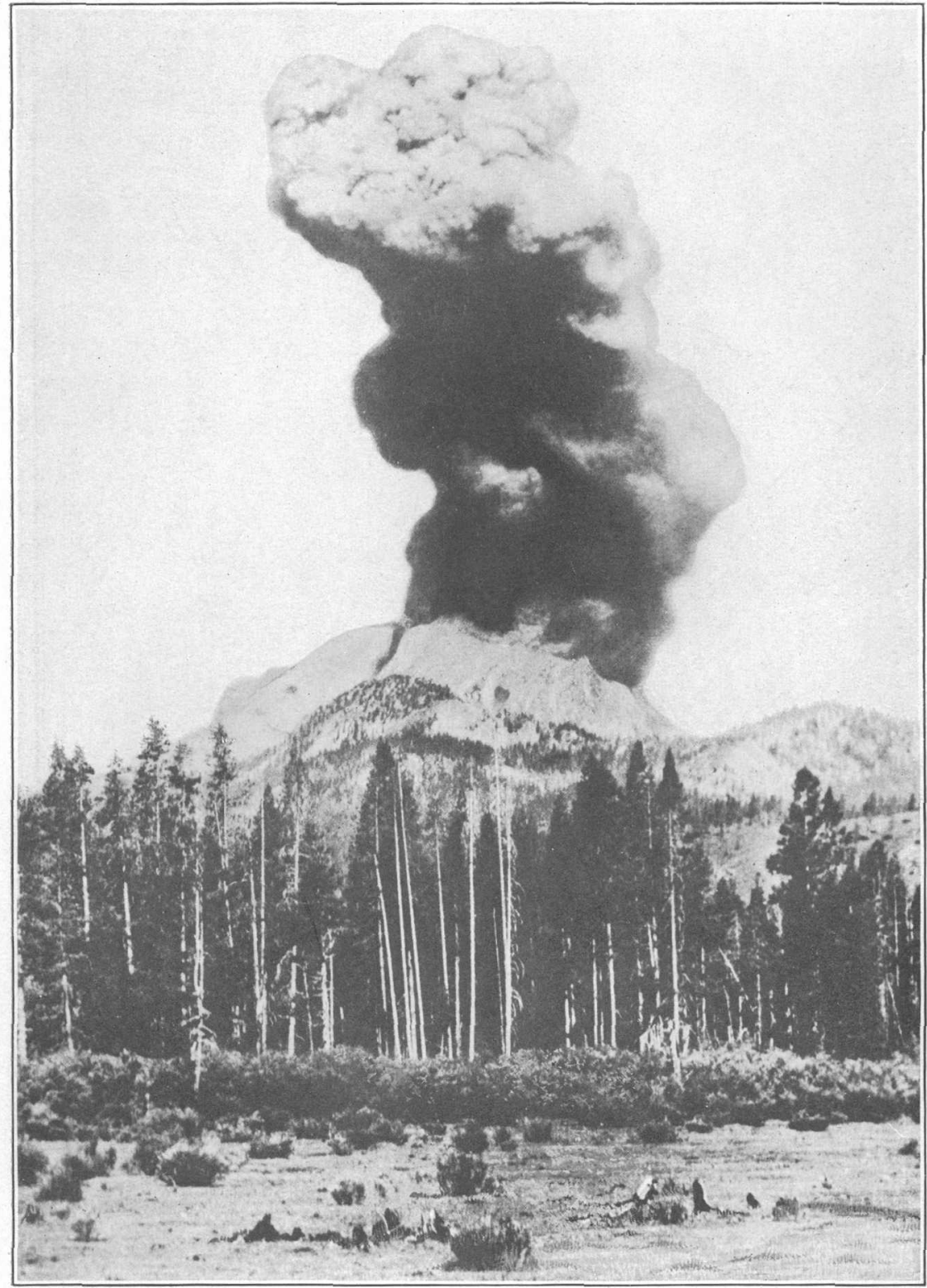

ERUPTION OF LASSEN PEAK, CAL., AT 12.30 P. M. AUGUST 22, 1914.

As seen from Lee's ranch, in Warner Valley, 5 miles southeast of Drakesbad and 12 miles southeast of Lassen Peak. The column of smoke is about 6,000 feet in height. Photograph copyrighted by Thompson, Susanville, Cal. 


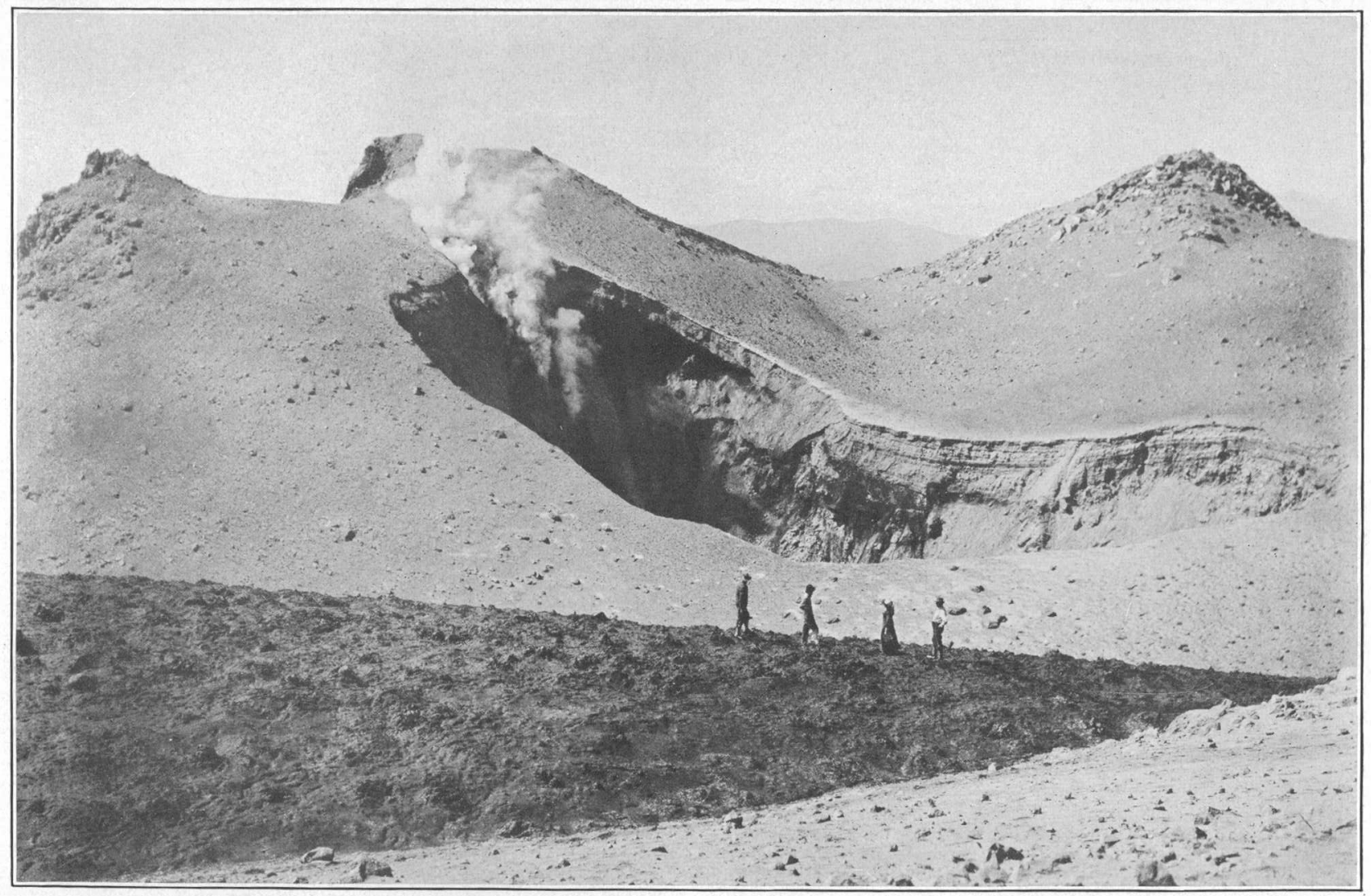

NEW CRATER OF LASSEN PEAK, CAL., AFTER 25 ERUPTIONS WITHIN THE OLD CRATER, AUGUST 17, 1914.

The banded material on the farther rim of the new crater has been thrown out by the recent eruptions and covered a layer of snow. The dark material in the foreground is a material on the farther rim of the new crater has been thrown out by the recent eruptions and covered a layer of snow. The dark material in the foregr
snowbank covered by 3 inches of wet dust. Some of the falling stones sank into the snow. Photograph copyrighted by Thompson, Susanville, Cal. 
Sacramento, and goes south on the east side of the valley. The main line continues down the west side of the valley. The distances given for the stations as far as Davis (p. 77) are measured by way of the main line. The distances given for stations south of Davis are measured by way of the Marysville line, which is 27 miles longer.

Surrounded by grain fields and groves of oranges and olives, Richfield lies to the left (east) of the railroad, in the valley of Thomas Creek. On this newly colonized tract wells have

Richfield.

Elevation 256 feet. Seattle 749 miles. been sunk and electric pumps installed. About 800 acres were irrigated in 1913. An electric pump and water flowing from an 8-inch pipe can be seen at milepost 181, on the left. In the 3 miles from Richfield to Corning the track follows a swale of recent alluvium, in which the soil is finer and darker than that of the gravel plains.

Corning is the center of the Maywood colony and has probably doubled its population since the last census. It is the shipping point for large numbers $\mathrm{cf}$ turkeys raised on the neighboring Corning.

Elevation 271 feet. Population 972.

Seattle 753 miles. plains, and for much dried fruit and olives. The locality has long been famous for peaches and prunes, but present interest centers in olive culture. The white building of mission architecture on the left of the track south of the station is an olive-pickling factory. Eucalyptus trees are abundant hare, and palms line the streets.

Three miles south of Corning the railroad swings toward the east, passing through Kirkwood and over the plains to Malton station, where it crosses the line between Tehama and Glenn counties. The road here runs over a gravelly deposit (alluvial fan) built up, during comparatively recent time, by Stony Creek, which has its source in the Coast Range. This deposit extends eastward from Black Butte, a basaltic crater 6 miles west of the railroad, to the river. Gravel from pits along Stony Creek is shipped to many parts of the valley for high-class concrete work and for railroad use.

Near Orland appear the well-made ditches of the Orland project of the United States Reclamation Service. Storage reservoirs have been constructed in the mountains to conserve the water Orland.

Elevation 255 feet. Population 836 . Seattle 766 miles.

of Stony Creek. The substantial concrete buildings of Orland attest the faith of its people in the permanence of prosperity under a Government irrigation project. The project is one of the smallest yet undertaken by the Government, the land to be irrigated including only about 14,000 acres, but it is the first unit in a vast scheme to reclaim a large portion of the Sacramento Valley. The soil and climate of this locality are adapted to a great variety of agricultural and horticultural products. The general elevation is 190 to 300 feet above sea level, the temperature from $26^{\circ}$ to $114^{\circ}$, and the annual rainfall 17 inches. The tract 
is in a citrus belt, and its oranges, lemons, grapefruit, and almonds ripen early. Grain has been grown upon this land for years. Under irrigation the staple crop has been alfalfa, and dairying is an important industry. Practically all the lands have been filed upon and can be acquired only by purchase from the present owners, who have subdivided their holdings into farms of 40 acres or less.

From Orland a branch line goes east 9 miles to Hamilton, a sugarbeet town on the river.

As Orland is left behind the Coast Range is in full view on the right. The foothills of this range show a certain evenness of crest which suggests that the tops of the hills are remnants of a surface that was once almost level (a peneplain). This old surface was possibly at one time continuous with the bench at the head of Sacramento Valley. previously noted. West of Orland it cuts across the beveled edges of upturned Cretaceous strata. The crest line of the Coast Range, while less even than that of the foothills, is suggestive of the former existence of a much older peneplain which probably extended over what are now the Klamath Mountains. In other words, both ranges simply represent what is left after an old, gently rolling surface has been uplifted and valleys have been eroded in it.

To the southeast appear the tops of the Marysville Buttes, a rough mass of mountains standing isolated in the middle of the flat valley, above which they rise about 2,000 feet. These buttes are the eroded remnants of an extinct volcano.

From Greenwood, 3 miles beyond Orland, nearly to Colusa Junction, a distance of 32 miles, is another straight stretch of north-south track.

Germantown is a typical village of the older type in the valley, now being quickened through the subdivision of some of the adjacent grain ranches and the development of the land Germantown. by irrigation. On the right (west) as the train Flevation 158 feet. leaves the town may be seen the numerous pumping Population 220.* Seattle 774 miles. plants of the Shaw ranch. Artesian water was struck here at a depth of 800 feet and flows at the rate of 200 gallons a minute.

Willows, the seat of Glenn County, is the headquarters of the Sacramento Valley Irrigation Co., whose operations are known as the Kuhn project. Water is pumped from Sacramento

\section{Willows.}

Flevation 134 feet. Population 1,139. Seattle 781 miles.

irrigation. Development by means of the ditch has stimulated well boring west and north of the town.

From Willows a branch line goes to Fruto, in the Coast Range. 


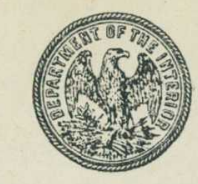

GEOLOGIC AND TOPOGRAPHIC MAP SHASTA ROUTE

From Seattle, Washington, to San Francisco, California Base compiled from United States Geological Survey Atlas Sheets, from railroad alignments and profiles suppined by
the Southern Pacific Company and from additional information collected with the assistance of this company

UNITED STATES GEOLOGICAL SURVEY GEORGE OTIS SMITH, DIRECTOR

David White, Chief Geologist R. B. Marshall, Chief Geographer 1915

Each quadrangle shown on the map with a name in parenthesis in the lower left corner is
Sheet of that name.

\section{EXPLANATION}

Stream deposits (alluvium and Red Bluff formation)

B Lava flows (basalt)

Auriferous river gravels and fine tuff

Tuffs (Tuscan tuff, Pliocene); gravels, sands, and clays
(Ione formation, Eocene)

Conglomerates, sandstones, and shales (Chico, Horse-
town, and Knoxville formations)

Sandstores and shales, with flinty beds (cherts) made
up of microscopic siliceous skeletons of radiolarians

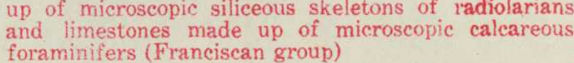

H Altered sedimentary and igneous rocks underlying

\section{Quaternary}

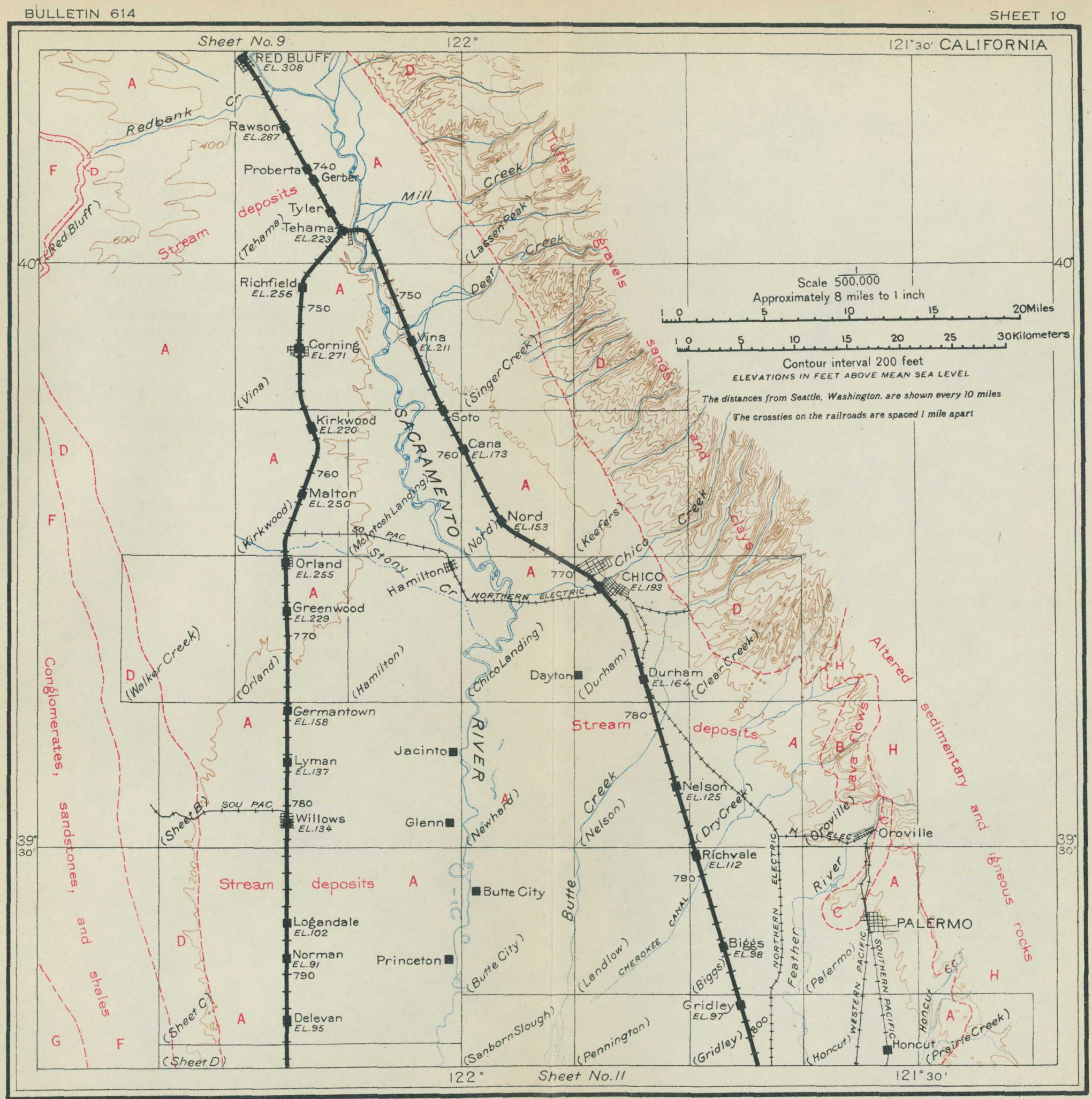


The stations of Logandale and Norman are passed in turn, and $1 \frac{1}{2}$ miles south of Norman station the railroad crosses from Glenn County into Colusa County. Near Delevan, the next station, as at many other places along the Shasta Route in California, the bright-yellow to orange-colored poppies (Eschscholtzia californica) form glowing clumps in spring and early in the summer. Beyond Maxwell (see sheet 11, p. 76), an old village of the grain-farming days, is Colusa Junction, where the Shasta Route crosses the Colusa

Maxwell.

Elevation 93 feet. Population 864.* Seattle 798 miles. \& Lake Railroad. This line runs from Colusa, on Sacramento River, westward to Lakeport, in Lake County. It passes at Sites the sandstone quarry that furnished the material for the Ferry Building in San Francisco. Lakeport, on Clear Lake, in the Coast Range, is in a farming region. Evidence of recent volcanic activity and the occurrence of deposits of quicksilver ore and sulphur give additional interest to the pretty country about Clear Lake.

Twenty miles east of Maxwell the rugged Marysville Buttes rise abruptly from the plain, forming a landmark that can be seen for many miles in all directions. ${ }^{1}$

The land near Williams is outside of the area served by the Sacramento Valley Irrigation Co.'s ditch, and the local

\section{Williams.}

Elevation 79 feet. Population 1,463.* Seattle 806 miles. farmers pump their own water. Several pumping plants may be seen south of the town. To the east is the Colusa Basin, a shallow trough which parallels the river as far south as Knights Landing, east of

Zamora station. When the levees along the river break this basin is flooded and forms a veritable inland sea from Colusa to Knights Landing Ridge.

West of Williams the bench of older alluvium becomes wider and more prominent and extends in a southeasterly direction to Yolo. North of the village this little plateau is about 400 feet above sea level

\footnotetext{
${ }^{1}$ The Marysville Buttes are a cluster of hills about 10 miles in diameter, culminating in South Butte, 2,132 feet above sea level. North Butte has an elevation of 1,863 feet. The central area, about 4 miles in diameter, is composed of andesite, a lava that was pushed up from the interior of the earth in a molten but stiff condition. Around the andesite is an irregular belt of sandstone and shales of Tertiary age, bent upward by the force of intrusion of the andesite so that they dip away from the center atangles of $18^{\circ}$ to $90^{\circ}$. An outer belt, about 2 miles wide, of tuffaceous breccias, consisting of angular

fragments of lava of various sizes with some pebbles of other rocks, surrounds the sandstone and shales. The material of these breccia beds probably once flowed from the crater of the volcano as a thick stony mud. The streams flowing down from the buttes have broad valleys which are filled with alluvium in their lower courses. The hills have an outer slope of 250 feet to the inile and a steeper in-facing scarp or bluff. A projection of the outer slope to the center would restore the outline of the old volcano, making it about 5,000 feet high, or over twice the present height.
} 
and covered with a scanty growth of oaks. The streams flow across the plateau or bench at right angles to the trend of the bluff that separates it from the present flood plain of the river and have cut through the alluvium into Cretaceous sandstone and shales that dip toward the valley. The older alluvium rests on the eroded edges of these beds. The bluff in this locality is a fault scarp; that is, it marks a line of faulting. This fault extends from Williams southeastward to Cache Creek and there turns south to Putah Creek.

The Coast Range west of Williams is a greatly crushed and faulted mass of Jurassic and Cretaceous rocks.

From Williams the road rises about 63 feet to

\section{Arbuckle.}

Elevation 42 feet. Population 1,249.* Seattle 817 miles. Arbuckle, situated on a fan-shaped deposit of recent alluvium supplied by the dissection of the earlier Pleistocene plateau. The principal industry here is almond growing.

At Harrington a branch road, called the Beet Line, turns off to Grimes and Colusa. The line between Colusa and Yolo counties is crossed at Hershey station. Dunnigan, the next

\section{Dunnigan.}

Elevation 67 feet. Population 333.* Seattle 827 miles. village, lies close under the escarpment of the plateau, which is here dissected by streams into rounded hills. On this land are grown wheat and barley, and the skill of the farmers in taking traction engines and combined harvesters over these hills is remarkable. Notwithstanding the recent changes in agriculture previously noted, the great staple product of the Sacramento Valley is still wheat. There are grain warehouses at nearly every station, and the traveler can not fail to realize that he is passing through one of the greatest wheat regions of the world. Near Dunnigan a newer industry is seen in thousands of acres planted with eucalyptus trees.

At the village of Zamora (Blacks Station post

Zamora.

Elevation 50 feet. Population 292.

Seattle 835 miles. office), the plain between the hills and Colusa Basin is very narrow and backwater from the tule land has been known to come within $1 \frac{1}{2}$ miles of the village. This is a country of fime oaks.

From Zamora the railroad rises about 30 feet to the village of Yolo on Cache Creek. This stream leaves the Coast Range through Capay Valley at Esparto and, crossing the plateau

Yolo.

Elevation 73 feet. Seattle 840 miles. of older alluvium, here 10 miles wide, cuts through the escarpment in a terraced canyon 3 miles west of Yolo. ${ }^{\circ}$ From this point it begins to deposit sediment brought from the mountains. In past time Cache Creek has built up a considerable area of country around Yolo and Woodland by means of a number of branches. One of these old branches, called Cache Creek Slough, extends northeastward from Yolo to Knights Landing on Sacramento River. The sediment deposited 


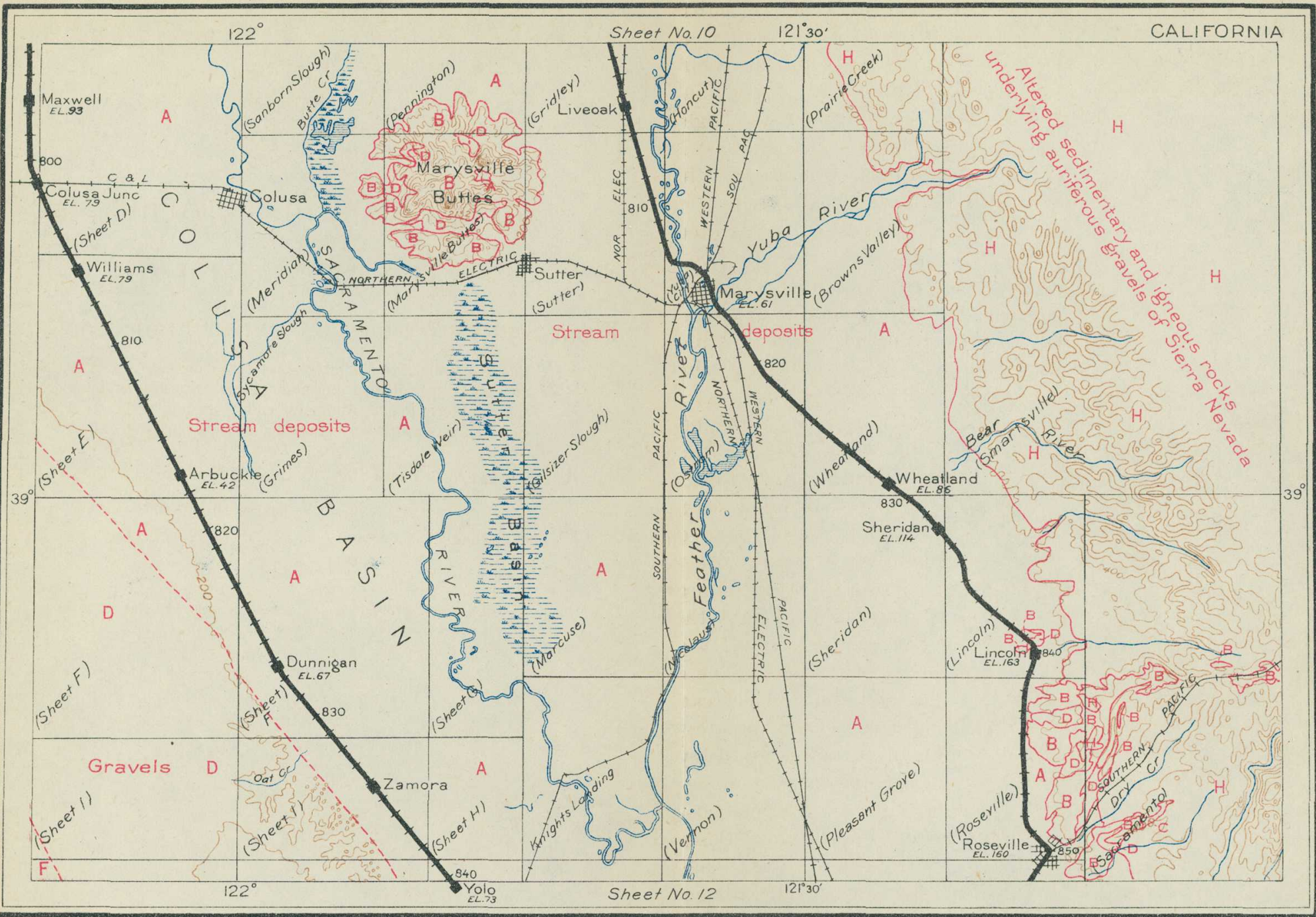

EXPLANATION

A Stream deposits (alluvium and Red Bluff formation)

B Lava flows and tuffs (andesites and some rhyolites)

C River gravels (auriferous) and fine tuffs

D Gravels, in part marine, locally auriferous, with marine sandstones and clays (Ione and Tejon formations)

F Conglomerate, sandstones, and shales (Chico, Horsetown, and Knoxville formations)

$\mathrm{H}$ Altered sedimentary and igneous rocks underlying gravels of Sierra Nevada
Quaternary

Tertiary
Cretaceous
$\left\{\begin{array}{l}\text { Mesozoic } \\ \text { and } \\ \text { Paleozoic }\end{array}\right.$

Scale $\frac{1}{500,000}$

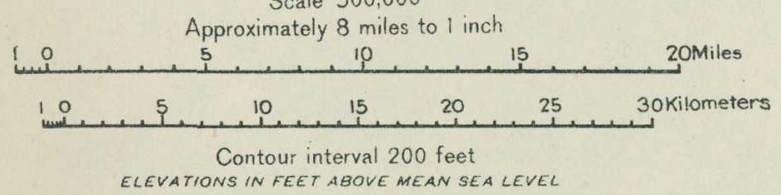

distances from Seattle, Washington, are shown every 10 miles

The crossties on the railroads are spaced I mile apart 


\section{GEOLOGIC AND TOPOGRAPHIC . MAP}

OF THE

\section{SHASTA ROUTE}

From Seattle, Washington, to San Francisco, California

Base compiled from United States Geological Survey Atlas Sheets, from railroad alignments and profiles supplied by the Southern Pacific Company and from additional information collected with the assistance of this company

\section{UNITED STATES GEOLOGICAL SURVEY}

\section{GEORGE OTIS SMITH, DIRECTOR}

David White, Chief Geologist

R. B. Marshall, Chief Geographer

1915

Each quadrangle shown on the map with a name in parenthesis in the lower left corner is mapped in detail on the U.S. G. S. Topographic Sheet of that name. 
by it has formed the Knights Landing Ridge, an elevation hardly discernible to the eye, which separates the Colusa Basin from a similar depression to the south known as the Yolo Basin. The fertile soil of the Yolo Basin is underlain by coarse gravel from which large supplies of ground water are obtained.

The largest pumping plant in the valley, the St. Louis plant of the Sacramento Valley Sugar Co., is near Yolo. It consists of 12 wells connected with an elsctrically driven 15 -inch centrifugal pump having a capacity of 7,000 gailons a minute. From this plant 1,200 acres were irrigated in 1913.

Woodland (see sheet 12, p. 80) is the seat of Yolo County and one of the oldest and richest towns in the valley. IrriWoodland. gation was begun here in 1856 by diversion from Elevation 60 feet. Cache Creek through the Moore ditch. The system Population 3,187. is now controlled 'by the Yolo Water, Light \& Power
Seattle 845 miles.

Co., which irrigated 23,000 acres in 1913. In that year about 7,000 acres east and north of Woodland were planted to sugar beets.

From Woodland the railroad passes through a rich farming region to Davis, where the Shasta Route joins the route from Omaha by way of Ogden and Sacramento to San Francisco.

\section{Davis.}

Elevation 42 feet. Population 750.*

Seattle 854 miles. 1 To the east is the level expanse of Yolo Basin, where yearly flooding prevents the growth of all except tule (Scirpus lacustris) and coarse grasses. To the west may be seen the low, reddish hills of older alluvium. Near Davis is the large farm of the University of California used for experimental and educational purposes. The country in this vicinity is an almost flat plain near sea level, but nevertheless high enough to provide drainage. With its rich fields of grain and orchard patches it has a decidedly prosperous look. Beyond Davis the Coast Range becomes more prominent, especially to the right, ahead of the train, showing as a low, dark ridge broken by one or more gaps. Valley and live oaks are again a common feature through the fields.

Along the Pacific coast, from the vicinity of Santa Barbara on the south to Humboldt County on the north, the Coast Ranges divide the Great Valley of California from the ocean. They are broken by the one great gap by which the combined Sacramento and San Joaquin rivers find outlet into the Bay of San Francisco. The Coast Ranges are geologically the most recent of the great structural features of the State. They are largely built up of folded and crushed Cretaceous, Jurassic, and Tertiary sedimentary rocks, which are in places broken through by andesitic and basaltic lavas and by older igneous rocks (diabase and other dark, heavy rocks, in part altered to serpentine).

\footnotetext{
${ }^{1}$ By way of main line; 881 miles by way of Marysville branch.
} 
Dixon is an agricultural town in Solano County. Beyond it the Coast Range now looms larger as the traveler proceeds westward. Elmira (elevation 79 feet), a junction whence a Dixon.

Elevation 61 feet. Seattle 889 miles. $^{1}$

branch road goes to Vacaville, Winters, and Rumsey, is next passed. Beyond Elmira the road approaches low foothills of the Coast Range-first a bare ridge, with gaps, through one of which the railroad passes over a slight rise. The factory of the Pacific Portland Cement Co. and adjacent shale quarries can be seen to the north. The limestone used here to mix with the shale is brought from a point near Auburn.

The traveler coming across the Sacramento Valley in the day during midsummer is likely to find the trip warm, but on reaching this gap in the Coast Range he almost invariably notices a change. The cool breezes sweeping in from the west and carrying the smell of the salt marshes become fresher as the train proceeds, and it is a reasonable precaution to have wraps handy from this point on.

Beyond the first spur of the Coast Range the valley again broadens. Higher mountains, more or less darkened by scrubby timber on their upper slopes, border the valley to the north and far to the south. If the air is moderately clear, Mount Diablo ${ }^{2}$ and the southern continuation of the Coast Range may be seen. A group of low, round, and grassy hills a few miles to the south are known as the Potrero Hills. (Potrero, pronounced po-tray'ro, is Spanish for horse pasture.)

Suisun (suey-soon', locally soo-soon', the name of an Indian tribe, said to mean great expanse) and the adjoining town of Fairfield (the seat of Solano County, population 834) are at the

Suisun.

Elevation 15 feet. Population 641 . Seattle 909 miles. edge of another swampy district green with tule. From this point the railroad is graded across the Suisun Flats, which are so near tidewater level in Suisun Bay, to the south, that no cultivation is

\footnotetext{
${ }^{1}$ Distances for stations from Dixon to San Francisco given by way of Marysville line; to get distance actually traveled by main line through Woodland deduct 27 miles.

${ }^{2}$ The general outline and isolated position of Mount Diablo have given the impression that this mointain is an old volcano. It represents, however, the higher portions of an overturned arch or anticline of sedimentary rocks thrust from the northeast toward the southwest. From its summit to the sea level at Carquinez (car-kee'ness) Strait is displayed a remarkably complete series of typical Coast Range formations, including Franciscan, Knoxville, Chico, Martinez, Tejon, Monterey, San Pablo, late Tertiary freshwater beds, Pleistocene, and Recent.

Although Mount Diablo is of moderate height (3,849 feet), its isolation and its situation on the edge of the Great Valley make it one of the finest viewpoints in the State. From its top, on a clear morning, the summits of the Sierra Nevada can be traced for over 200 miles. Lassen Peak is often visible and sometimes Mount Shasta. The Great Valley appears divided into squares like a checkerboard by the section-line roads and fences. The San Francisco Bay region is sometimes hidden by a snowy sea of fog. The mountain is easily reached from San Francisco, though at present the ascent must be made on foot or by driving. The road, which goes practically to the summit, will probably be fitted for automobile travel.
} 


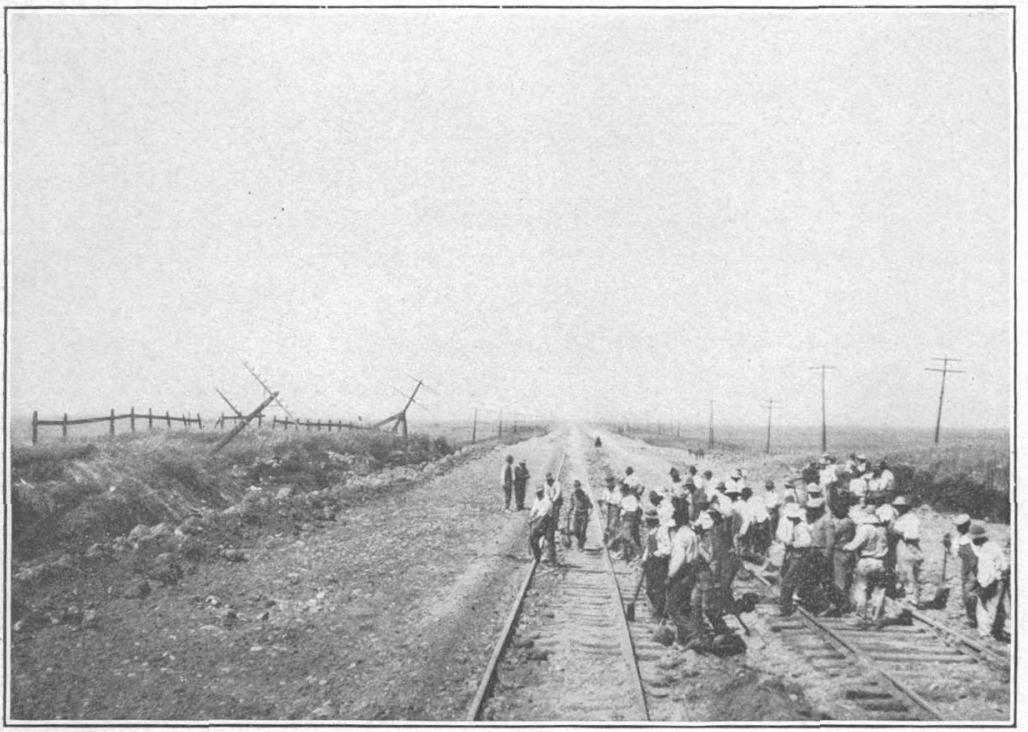

A. SINKS OF SUISUN FLATS, CAL.

Railroad crew at work raising and regrading a recent sink. Note upward-bulging mud ridge on each side and tilted telegraph poles on the left.

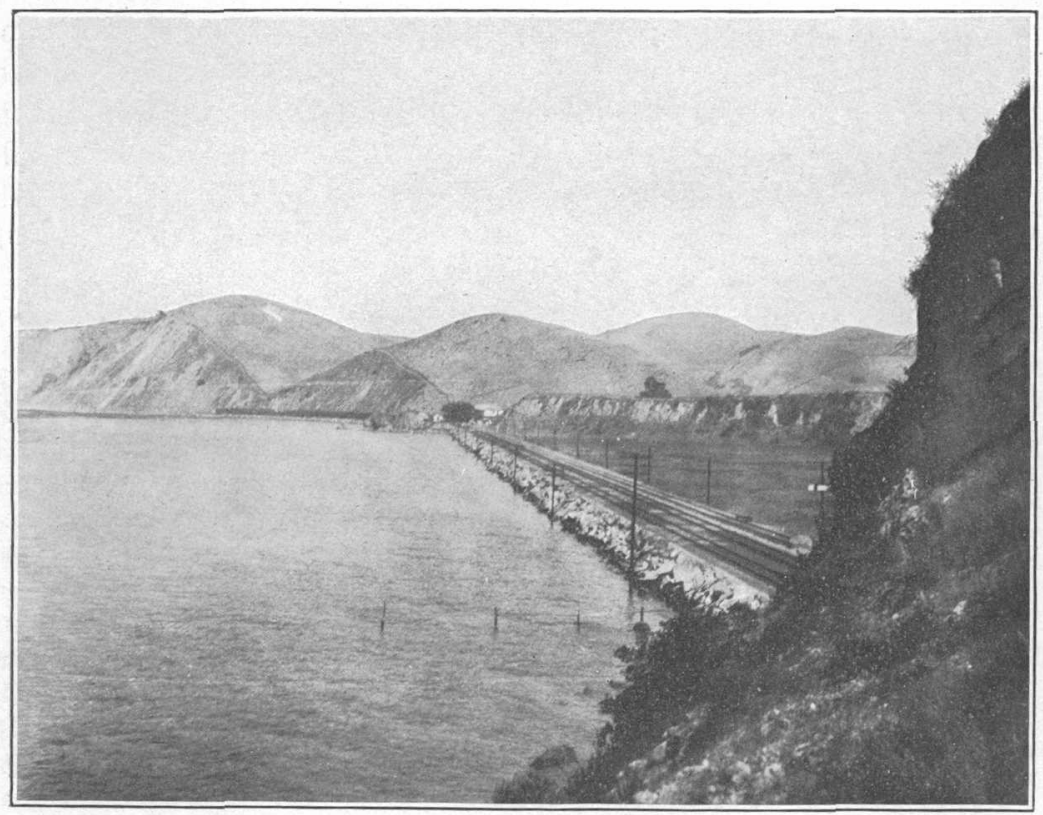

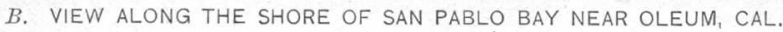

Terrace in middle represents raised beach that can be seen at several points around San Francisco Bay. 
possible under present conditions, though the camps of several duck-shooting clubs are situated among the sloughs. The railroad has encountered much difficulty in maintaining its grade across this soft ground. Certain spots have been continually sinking ever since the first construction of the road, and it is seldom, even now, that in going over this part of the route the traveler does not see work trains and grading crews busily engaged in filling and raising some sunken portion of the track. (See Pl. XXIV, A.) Mud ridges have risen along the tracks on both sides, and their broken and lumpy surfaces indicate a slow flowing mass of mud squeezed out by the weight and vibration of passing trains. It is said that as much as 30,000 carloads of coarse gravel ballast have been dumped into one of these spots.

Beyond the marshes the railroad meets the rocky headlands that here close in upon Carquinez Strait. Some fine exposures of Cretaceous and Tertiary sandstones and shales may be seen in the cliffs and road cuts around Army Point.

Near Benicia, on the left, is a United States arsenal and signal station. Benicia (named by Gen. Vallejo after his wife) is a manufacturing town with deep-water frontage. It conBenicia.

Elevation 6 feet. Population 2,360. Seattle 921 miles. tains, besides the arsenal, tanneries and other commercial establishments. Southeast of Benicia, across the strait, is the town of Martinez, near which John Muir, California's great naturalist, lived for many years. The tall smokestack east of the town belongs to the smelter of the Mountain Copper Co., which mines its ore near Kennett, in Shasta County. At this smelter sulphur fumes are utilized in making sulphuric acid, which in turn is used in treating rock phosphate brought from the company's mine near Montpelier, Idaho, and here turned into fertilizer. Just beyond Benicia the train is run onto a ferryboat and is carried across Carquinez Strait to Port Costa, a distance of a mile.

The geologic section from Benicia and Port Costa to the vicinity of Berkeley and Oakland is particularly interesting, as in it are represented many of the characteristic sedimentary formations of the Coast Range. The stratigraphic section is quite different from that of corresponding age in the Sierra foothills.

Port Costa (see sheet 13, p. 90), the western ferry terminus, is a shipping point, particularly for grain, which comes

\section{Port Costa.}

Elevation 11 feet. Seattle 926 miles. from the interior valley ${ }^{1}$ and is here loaded into oceangoing vessels. A long line of galvanized-iron grain warehouses may be seen on the water front.

${ }^{1}$ Agriculture in California had its beginning in wheat raising, and wheat was long the State's greatest crop. Its production steadily increased, until about 1884 , to over $54,000,000$ bushels annually. The levelness of the great grain fields of the valley led to the utilization of combined harvesters, steam gang plows, and other farm machinery of extraordinary size and efficiency. Recently, however, fruit growing has become a more important industry than grain farming. In the value of its fruit crop California leạds all the other States. 
On leaving Port Costa the train skirts the south shore of Carquinez Strait, where the steep bluffs offer many good exposures of folded sedimentary rocks. The first rocks seen are Upper Cretaceous (Chico) sandstone and shale. The rocks have a moderately steep westward dip and trend almost directly across the course of the railroad, so that as the train proceeds successively younger formations are crossed. At Eckley, a short distance beyond Port Costa, brick is manufactured from the Cretaceous shale. At Crocket is a large sugar refinery. Mare Island, across Carquinez Strait, is the site of the United States navy yard, which, however, is not readily discerned from this point. The Cretaceous shales and sandstones continue to Vallejo Junction and a little beyond.

On the southeast side of San Pablo Bay, near the west end of Carquinez Strait, there are wave-cut terraces and elevated deposits of marine shells of species that are still living. These terraces and deposits do not show south of San Pablo Bay, and therefore seem to indicate the recent elevation of a block including only a portion of the shore around the bay. This block probably includes the Berkeley Hills and a considerable territory to the east, perhaps even extending to Suisun Bay.

From Vallejo Junction a ferry plies to Vallejo (val-yay'ho), which is on the mainland opposite the navy yard and from which railroad

\section{Vallejo Junction.}

Elevation 12 feet. Seattle 929 miles. lines extend into the rich Napa and Sonoma valleys.

Santa Rosa, the home of the famous Luther Burbank, is in the Sonoma Valley. Vallejo was named from Gen. Mariano Guadalupe Vallejo, who played a prominent part in the early history of California. It was the capital of the State from 1851 to 1853. Beyond Vallejo Junction Carquinez Strait begins to open out into San Pablo Bay. ${ }^{1}$ (See Pl. XXIV, B, p. 78.)

The dark Cretaceous shales near the railroad station at Vallejo Junction are soon succeeded by brown shales and massive sandstones belonging higher in the Cretaceous system. The contact between the Chico and the Martinez (Eocene) beds is in a fault zone cut by

1 The section along the shore of San Pablo Bay between Vallejo Junction and Pinole (see map and section on stub of sheet 13, p. 90) includes six of the most widespread divisions of the sedimentary series in the Coast Range region of California. The formations or groups represented are the Chico (Upper Cretaceous), Martinez (Eocene), Monterey (earlier Miocene), San Pablo (later Miocene), Pinole tuff (Pliocene), and Pleistocene. The only large divisions of the middle Coast Range sequence not represented are the Fran- ciscan (Jurassic?), Tejon (Eocene), and Oligocene, all of which are found within a few miles to the east and south.

In the San Pablo Bay section all the formations below the Pleistocene are inluded in a syncline, on the northeastc side of which the strata are nearly vertical, but on the southeast side the dip of the beds is lower. The Pleistocene beds rest horizontally across the truncated edges of the Miocene and Pliocene. The aggregate thickness of the sediments in the San Pablo Bay section is not less than 


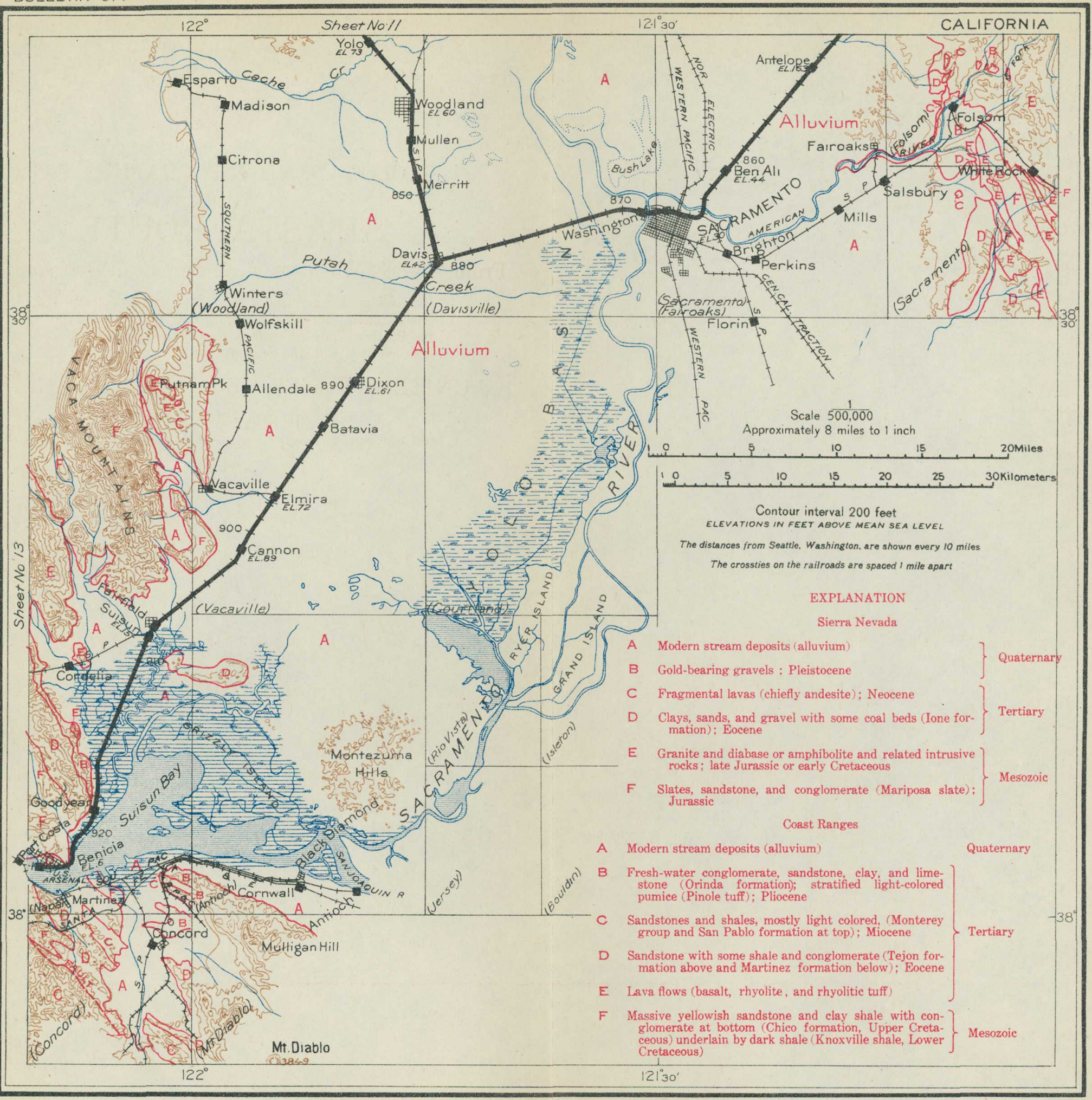




\section{GEOLOGIC AND TOPOGRAPHIC MAP OF THE SHASTA ROUTE}

From Seattle, Washington, to San Francisco, California

Base compiled from United States Geological Survey Atlas Sheets, from railroad alignments and profiles supplied by the Southern Pacific Company and from additional information collected with the assistance of this company

\section{UNITED STATES GEOLOGICAL SURVEY}

GEORGE OTIS SMITH, DIRECTOR

David White, Chief Geologist

R. B. Marshall, Chief Geographer 1915

Each quadrangle shown on the map with a name in parenthesis in the lower left corner is mapped in detail on the U. S. G. S. Topographic Sheet of that name. 
the railroad tunnel a short distance west of Vallejo Junction. Just beyond the tunnel the contact between the Martinez and the Monterey (Miocene) is clearly shown in a high cliff to the left, opposite the Selby Smelting Works, where the buff-colored Monterey sandstones and shales rest with marked unconformity upon the black Eocene shales. Near the contact the Eocene shale is filled with innumerable fossil shells of boring Miocene mollusks. The Monterey beds are extraordinarily well exposed in the cliffs to the left, and immediately beyond the contact, where they consist of fine buff shales with shaly sandstones and thin bands of yellow limestone.

After leaving these cliff exposures the train passes Tormey station, crosses a little swamp, and approaches a tunnel cut into vertical cliffs of massive gray sandstone; this is the type locality of the San Pablo formation (upper Miocene). The refining plant of the Union Oil Co., at the east end of this tunnel, is located on the upper part of the San Pablo beds. Vertical beds of massive tuff immediately west of the oil refinery represent the lower part of the Pinole tuff. Beyond these beds the train crosses another swamp and enters a cut in which white volcanic ash beds of the Pinole tuff dip at a relatively low angle to the northeast. This change in dip shows that these beds are on the southwest side of the San Pablo Bay syncline, the axis of which passes through the swamp area. Resting upon the tilted ash deposits in this part of the section are horizontal beds of Pleistocene shale.

The name Rodeo (ro-day'o), meaning "round-up," indicates that the station so called was formerly a cattle-shipping point. Beyond

\section{Rodeo.}

Elevation 12 feet. Seattle 932 miles.

Rodeo the train enters a series of cuts. Near the station are exposures of massive tuffs close to the base of the Pinole tuff. Beyond this point the San Pablo (Miocene) appears, with low dips to the northeast. In the sea cliffs on San Pablo Bay a few yards from the railroad are excellent exposures of the Miocene capped by Pleistocene shale. At Hercules, where there are large powder works, the railroad cut

8,000 feet. With the exception of the Pliocene and a portion of the Pleistocene, all the formations are of marine origin. A portion of the Pinole tuff was certainly deposited in fresh water. The Pleistocene beds were deposited under varying marine, estuarine, and fluvial conditions.

Fossil remains are found in all the formations of the San Pablo Bay section, and at least six distinct faunas are represented. Very few specimens have been procured in the Chico near the line of the railroad, but abundant fossils are found in the same formation a few miles to the east. The Martinez fauna is represented in the cliff opposite the Selby smelter. The Monterey and the San Pablo contain abundant remains. The fresh-water fauna of the Pinole tuff is represented by molluscan species. Leaves and remains of vertebrates are also present. The Pleistocene shale contains abundant marine shells of a few species, with mammal bones representing the elephant, horse, camel, bison, ground sloth, antelope, lion, wolf, and other forms. 
is in broken shale of the Monterey group, the same beds that were seen near the Selby smelter, on the northeast side of the syncline. Beyond Hercules the railroad passes over Monterey shale to the town of Pinole (pee-no'lay, a Spanish term used by the Indians for parched grain or seeds), where the Pinole tuff is in contact with the

Pinole.

Population 798. Seattle 935 miles.
Monterey and is covered by a thick mantle of the Pleistocene shale. In the cuts southwest of Pinole the rocks exposed are all either steeply inclined Pliocene tuffs or horizontal Pleistocene beds.

At Krieger, where the tracks of the Santa Fe Route may be seen approaching the bay front from the south, is a so-called "tank farm." The oil-storage tanks, which belong to the Standard Oil Co., are beyond the Santa Fe line. Beyond Sobrante station is Giant, another powder factory, and beyond that are pottery works which obtain clay from Ione, in the Sierra Nevada. The bay shore near Oakland is largely given over to industrial uses, on account of its facilities for rail and water transportation.

Beyond Giant the foothills retreat from the bay shore and the railroad enters the broad lowland on which the cities of Berkeley and

\section{San Pablo.}

Elevation 30 feet. Seattle 940 miles.
Oakland are built. Near San Pablo, in the vicinity of San Pablo and Wildcat creeks, there is a gravelfilled basin. Many wells sunk in this gravel may be seen near the tracks, and from them a municipal water company and both railroads obtain water. West and southwest of San Pablo station a line of hills shuts out a view of San Francisco Bay. These hills constitute the Potrero San Pablo, so called because, being separated from the mainland by marshes, they were a convenient place in which to pasture horses during the days of Mexican rule, when fences were practically unknown. The hills are made up wholly of sandstone belonging to the Franciscan group. ${ }^{1}$

\footnotetext{
${ }^{1}$ The rocks of the Franciscan group comprise sandstones, conglomerates, shale, and local masses of varicolored thinbedded flinty rocks. The flinty rocks consist largely of the siliceous skeletons of minute marine animals, low in the scale of life, known as Radiolaria, and on this account they are known to geologists as radiolarian cherts. All the rocks mentioned have been intruded here and there by dark igneous rocks (diabase, peridotite, etc.), which generally contain a good deal of magnesia and iron but little silica. The peridotites and related igneous rocks have in large part undergone a chemical and mineralogic change into the rock

known as serpentine. Closely associated with the serpentine as a rule are masses of crystalline laminated rock that consist largely of the beautiful blue mineral glaucophane and for that reason are called glaucophane schist. Schist of this character is known in comparatively few parts of the world but is very characteristic of the Franciscan group. It has been formed from other rocks through the chemical action known as contact metamorphism, set up by adjacent freshly intruded igneous rocks. The Franciscan group is one of the most widespread and interesting assemblages of rocks in the Coast ranges.
} 
On the other side of them are wharves, warehouses, and large railway shops belonging to the Santa Fe system. From that side, also, the Santa Fe ferry plies to San Francisco.

Richmond, on both the Southern Pacific and the Santa Fe lines, is becoming a busy shipping, railroad, and manufacturing point, on

\section{Richmond.}

Population 6,802. Seattle 942 miles. account of the congestion of the water front of Oakland and San Francisco. The hills on the east side of the track, known to old Californians as the Contra Costa Hills but now often referred to as the Berkeley Hills, rise steeply from the plain. The most conspicuous summit from the west is Grizzly Peak (1,759 feet), but Bald Peak, just east of it, is 171 feet higher. The hills are generally treeless on their exposed western slopes, although their ravines and the eastern slopes are wooded. ${ }^{1}$

Beyond San Pablo and Richmond the rocks of the Franciscan group outcrop in low hills. At Stege the railroad is still close to the shore of the bay. Between this place and the hills is one of the suburbs of Berkeley known as Thousand Oaks. The traveler can get here an unobstructed view out over the bay and through the Golden Gate. Mount Tamalpais is on the right and San Francisco on the left. Just to the left of the Golden Gate the white buildings of the Exposition grounds can readily be distinguished if the day is at all clear. At Nobel station a little wooded hill of Franciscan rocks stands close to the railroad on the left. Beyond Nobel an excellent view may be had of the hilly portion of the city of Berkeley.

West Berkeley station, also known as University Avenue, is in the older part of the city of Berkeley, and the center of the city is now almost $2 \frac{1}{2}$ miles back toward the hills. Berkeley was

\section{Berkeley.}

Elevation 8 feet. Population 40,434 Seattle 948 miles.

California. One of them, looking out over the bay and the Golden Gate, quoted the familiar line, and another suggested "Why not name it Berkeley?" and Berkeley it became.

\footnotetext{
${ }^{1}$ The geologic structure of these hills is rather complicated. Along their southwest base, between Berkeley and Oakland, is a belt of the sandstones, cherts, and schists belonging to the Franciscan (Jurassic?) group and characteristically associated with masses of serpentine. Overlying the Franciscan rocks are sandstones, shales, and conglomerates $/$ Pliocene age.

of Cretaceous, Eocene, and Miocene age. These in turn are overlain by tuffs, freshwater beds, and lavas of Pliocene and early Quaternary age. The general structure of the ridge east of Berkeley is synclinal, the beds on both sides dipping into the hills. The upper part of Grizzly Peak is formed chiefly of lava flows of
} 
The University of California was founded in 1868. It is one of the largest State universities in America, including besides the regular collegiate and postgraduate departments at Berkeley the Lick Observatory, on Mount Hamilton; colleges of law, art, dentistry, pharmacy, etc., in San Francisco; the Scripps Institution for Biological Research, at La Jolla, near San Diego; and other laboratories for special studies elsewhere. It is a coeducational institution and had a total enrollment for 1914-15, not including that of the summer school, of 6,202 . The members of the faculty and other officers of administration and instruction number 890 . The university buildings at Berkeley are beautifully situated and have a broad outlook over San Francisco Bay. Their position can readily be identified from the train by the tall clock tower. Another prominent group of buildings occupying a similar site just south of the university grounds is that of the California School for the Deaf and the Blind.

Just before reaching Oakland (Sixteenth Street station) the train passes Shell Mound Park. The mound, which is about 250 feet long and 27 feet high, is on the shore of the bay close to the right side of the track. It is composed of loose soil mixed with an immense number of shells of clams, oysters, abalones, and other shellfish gathered for food by the prehistoric inhabitants of the region and eaten on this spot. The discarded shells, gradually accumulating, built up the mound. Such relics of a prehistoric people are numerous about the bay, for over 400 shell mounds have been discovered within 30 miles of San Francisco. The mound just described is one of the largest, and from excavations in it a great number of crude stone, shell, and bone implements and ornaments have been obtained. The mounds evidently mark the sites of camps or villages that were inhabited during long periods, for the accumulation of such refuse could not have been very rapid. Archeologists who have studied the mound say that it must have been the site of an Indian village over a thousand years ago, and that it was probably inhabited almost continuously to about the time when the Spaniards first entered California.

The first stop in the city of Oakland is made at the Sixteenth Street station, about $1 \frac{1}{2}$ miles from the business center of the city. Oakland is the seat of Alameda County and lies on the eastern Oakland.

Elevation 12 feet. Population 150,174. Seattle 951 miles. shore of San Francisco Bay directly opposite San Francisco. Its name is derived from the live oaks which originally covered the site. It is an important manufacturing center and has a fine harbor with 15 miles of water front. Visitors to Oakland should if possible take the electric cars to Piedmont, from which a fine view may be had of San Francisco, the bay, and the Golden Gate. This view is especially good 
at sunset. A walk or drive to Redwood Peak'takes the visitor past the former home of Joaquin Miller, author of "Songs of the Sierras" and many other familiar poems, and affords equally fine views.

Leaving the station at Sixteenth Street, the train skirts the west side of the city and runs out on a pier or mole $1 \frac{1}{3}$ miles long, from which the rest of the journey must be made on the San Francisco ferries. The distance across the bay is 4 miles, and the trip is made in about 20 minutes. In crossing the bay the traveler sees Goat (or Yerba Buena), Alcatraz, and Angel islands to the right, Marin Peninsula beyond them, and the Golden Gate opening to the west of Álcatraz.

Goat Island lies close to the ferry course across the bay. Like most of the other islands in the bay, it is owned by the Government. On the nearest point there is a lighthouse station, and below it the rocky cliff is painted white to the water's edge. Just to the right of this is the supply station for the lighthouses of the whole coast from Seattle to San Diego. Behind this station is the United States naval training station, of which the officers' quarters may be seen on the hillside and the men's quarters near the larger buildings below. At the extreme northeast point of the island is a torpedo station, where torpedoes are stored for use in the coast defense.

On Alcatraz, the small island west of Goat Island, is a United States military prison, and on Angel Island, north of Alcatraz, are barracks and other military buildings, a quarantine station, and an immigrant station.

Few people in viewing the Bay of San Francisco think of it in any other way than as a superb harbor or as a beautiful picture. Yet it has an interesting geologic story.. The great depression in which it lies was once a valley formed by the subsidence of a block of the earth's crust_-in other words, the valley originated by faulting. The uplifted blocks on each side of it have been so carved and worn by erosion that their blocklike form has long been lost. Erosion also has modified the original valley by supplying the streams with gravel and sand to be carried into it and there in part deposited. The mountains have been worn down and the valley has been partly filled. Possibly the valley at one time drained out to the south. However that may be, at a later stage in its history it drained to the west through a gorge now occupied by the Golden Gate. Subsidence of this part of the coast allowed the ocean water to flow through this gorge, transforming the river channel into a marine strait and the valley into a great bay. Goat Island and other islands in San Francisco Bay suggest partly submerged hills, and such in fact they are. 
San Francisco, the chief seaport and the metropolis of the Pacific coast, is the tenth city in population in the United States and the largest and most important city west of Missouri San Francisco.

River. The population in 1910 showed a gain of 20 Population 416,912. Seattle 957 miles. per cent since 1900 . The city is beautifully situated at the north end of a peninsula, with the ocean on one side and the Bay of San Francisco on the other. The bay is some 50 miles in length and has an area of more than 300 square miles. The entrance to the bay lies through the Golden Gate, a strait about 5 miles long and a mile wide at its narrowest point.

The site of the city is very hilly, and a line of high rocky elevations runs like a crescent-formed background from northeast to southwest across the peninsula, culminating in the Twin Peaks, 925 feet high. Telegraph Hill, in the northeastern part of the city, is 294 feet above sea level. Here stood the semaphore which signaled the arrival of ships in the days of the gold seekers. The city has been laid out without the slightest regard to topography, consequently many of the streets are so steep as to be traversable only by cable cars and pedestrians. The waters of the bay formerly extended westward to Montgomery. Street, and most of the level land in the business section of San Francisco has been made by filling.

Golden Gate Park, containing 1,014 acres and extending westward from the city to the ocean, was a waste of barren sand dunes in 1870 , but skillful planting and cultivation have transformed it into one of the most beautiful semitropical public parks in the country. At its west end is the famous Cliff House, overhanging the sea, and a short distance out from the shore are the Seal Rocks, where the great sea lions may often be seen. The Sutro Baths near by, named after Adolph Sutro, constructor of the famous Sutro tunnel on the Comstock lode, contain one of the largest inclosed pools in the world.

San Francisco Bay is the largest and most active harbor of the Pacific coast. Besides the coastwise routes, the port maintains commerce. steamship connections with Australia, Hawaii, Mexico, Central and South America, the Philippine Islands, China, and Japan. The direct foreign trade is chiefly with British Columbia, South America, China, and Japan. Although the export grain business has now largely shifted to the ports of Oregon and Washington, San Francisco's permanence as one of the greatest ports of the country is assured by its advantageous position, its wealth of back country, and its command of trans-Pacific and transcontinental trade routes. Three large railroad systems-the Southern Pacific (with two transcontinental lines), the Atchison, Topeka \& Santa $\mathrm{Fe}$, and the Western Pacific-connect it with the East. Lines of the Southern Pacific Co. connect the city with different parts of the State and with the northern transcontinental lines. 
The Northwestern Pacific serves Mendocino, Sonoma, and Marin counties, on the north, and several smaller lines radiate from different ports on the bay. Only one railroad line, the Coast Line of the Southern Pacific, actually enters the city. The other roads have their terminals in Oakland and other cities around the bay.

The first settlement on the present site of San Francisco dates from 1776. It consisted of a Spanish military post (presidio) and History. the Franciscan mission of San Francisco de Asís. In 1836 the settlement of Yerba Buena (yair'ba bway'na) was established in a little cove southeast of Telegraph Hill. The name San Francisco was, however, applied to all three of these settlements. The United States flag was raised over the town in 1846, and the population rapidly increased, reaching perhaps 900 in May, 1848. The news of the gold discoveries was followed by the crowds of fortune seekers, so that by the end of 1848 the city had an estimated population of 20,000. From that time on San Francisco has grown rapidly. The first regular overland mail communication with the East was established by pony express in 1860 , the charge for postage being $\$ 5$ for half an ounce. In 1869 the completion of the Central Pacific Railway to Oakland marked the beginning of transcontinental railway communication.

The city suffered from severe earthquakes in 1839, 1865, 1868, and 1906. In respect to property loss the disaster of April 18, 1906, was one of the great catastrophes of history. The actual damage to the city by the earthquake was comparatively slight, but the water mains were broken and it was consequently impossible to check the fires which immediately broke out and which soon destroyed a large part of the city, including most of the business section. Some 500 persons lost their lives, and the estimated damage to property was between $\$ 350,000,000$ and $\$ 500,000,000$. Reconstruction began at once, and the city was practically rebuilt in the three years following the earthquake.

The Ocean Shore Railroad (station at Twelfth and Mission streets) and connecting automobile line afford a good opportunity to see the geology along the shore from San Francisco to Excursions from Santa Cruz. The return trip may be made by railroad San Francisco. or stage across the Santa Cruz Mountains. For a distance of $4 \frac{1}{2}$ miles north of Mussel Rock (11.9 miles from San Francisco) there is exposed in the bluffs along the coast a remarkable section of the Merced (Pliocene) formation, consisting of about 5,800 feet of highly inclined marine clays, shales, sandstones, conglomerates, and shell beds. In these beds have been found fossil remains of 53 species of marine animals, mostly mollusks, of which three-fourths are still represented by forms living in the ocean to-day. The San Andreas rift (the fracture along which displacement occurred in the 
San Francisco earthquake of 1906) passes out to sea at the mouth of a little ravine half a mile north of Mussel Rock and is crossed by the railroad. The exposures of the Merced formation along the sea cliffs were much finer before the San Francisco earthquake, which shook down some of the cliffs. From Tobin (18.1 miles) to Green Canyon (21.1 miles) the bed of the Ocean Shore Railroad is cut in bold sea cliffs high above the water and affords not only fine shore scenery but also an excellent section of rocks that probably belong to the Martinez (Eocene) formation. The contact of these rocks with a large mass of pre-Franciscan granite (quartz diorite), which forms Montara Mountain, a bold ridge that extends southeastward from this part of the coast, is crossed by the railroad between Tobin and Green Canyon. At the north end of Seal Cove, opposite Moss Beach station (24.1 miles), the bowldery and fossiliferous sea-beach beds here forming the base of the Merced (Pliocene) and resting on the granite of Montara Mountain are well exposed.

This delightful excursion may be extended down the coast to Pescadero, and the return made by stage across the range and rift zone to San Mateo; or the traveler may continue down the coast to Santa Cruz and return across the range on the Southern Pacific line either by way of the Big Trees and Los Gatos or by Pajaro and Gilroy.

The characteristic thin-bedded radiolarian chert of the Franciscan group is well exposed about Strawberry Hill, in Golden Gate Park. There are good exposures of the chert also on Hunter Point, reached most readily by the Kentucky Street cars from Third and Market streets. The principal rock of the point is serpentine. A mass of basalt in the sea cliffs on the south side presents a remarkable spheroidal and variolitic structure.

The summit of Mount Tamalpais is very easily and comfortably reached by ferry to Sausalito, electric train to Mill Valley, and a mountain railway to the hotel on the top. The ferry trip is one of the best to be had on the bay. The steamer passes close to the small island of Alcatraz, used as a military prison. To the west may be seen the ocean through the Golden Gate. Angel Island, with its interesting glaucophane schists, serpentine, and other rocks, lies to the right as the boat approaches Sausalito. The sedimentary rocks of both islands belong to the Franciscan group and are chiefly sandstone. The trip from Sausalito to Mill Valley by the Northwestern Pacific Railroad gives the traveler opportunity to see some characteristic bay-shore scenery and particularly to note how the waters of the bay appear to have flooded what was once a land valley. Mill Valley is named from an old Spanish sawmill, the frame of which is still standing. The views obtainable from the scenic railway and from the summit of Mount Tamalpais are extensive and varied. To 
the south may be seen San Francisco and Mount Hamilton $(4,444$ feet). To the southeast is Mount Diablo (3,849 feet), through which runs the meridian and base line from which the public-land surveys of a large part of California are reckoned. Nearer at hand is the bay, with its dark-green bordering marshes, through which wind serpentine tidal creeks. Close under the mountain to the north is Lake Lagunitas (an artificial reservoir), and beyond it ridge after ridge of the Coast Range. To the west is the vast Pacific.

From the summit of Tamalpais one sees clearly that San Francisco Bay is a sunken area in which hilltops have become islands and peninsulas. This area is the northern extension of the crustal block whose sinking formed Santa Clara Valley. A later sag admitted the ocean into the valley, and the Golden Gate, formerly a river gorge, became a strait.

Mount Tamalpais has really three peaks: East Peak (2,586 feet), near which the Tavern of Tamalpais is situated; Middle Peak (about 2,575 feet); and West Peak (2,604 feet). From the grassy hills $1 \frac{1}{2}$ miles west of West Peak there is a good view of Bolinas Lagoon, through which passes the earthquake rift, but for close views of the rift topography the visitor should walk or drive through the valley between Bolinas Lagoon and Tomales Bay, where the effects of the movement of 1906 are still in many places clearly evident.

Mount Tamalpais is composed wholly of the sediments of the Franciscan group and the igneous rocks usually associated with them, though it is chiefly sandstone. A mass of radiolarian chert occurs near the tavern, and serpentine may be seen at several places beyond West Peak. To one fond of walking and of marine views, a trip on foot to West Peak, thence down the main ridge to Muir Woods (redwoods), and back across the hills to Mill Valley may be heartily recommended. The distance is probably 8 or 9 miles. The Muir Woods, which bear the name of California's greatest nature lover, form a national monument, presented to the nation by William Kent, now Member of Congress from the first California district, for the purpose of preserving untouched by the lumberman one area of redwoods. No fitter memorial could be dedicated to the memory of John Muir, whose writings have contributed so much to the movement for preserving in national ownership, for public enjoyment, some of our finest scenic resources.

The geologic event of greatest human interest on the Pacific coast in modern times was the San Francisco earthquake of 1906 . It was

The earthquake rift.

produced by a sudden movement of the rocks (faulting) along opposite sides of a fracture which may be traced for many miles in the Coast Range. The fissure existed before the earthquake of 1906 , and it is evident from the relations of hills and valleys along it that it has been the scene of 
earlier and, for the most part, prehistoric movements. The last movement was mainly horizontal and in places amounted to about 20 feet. The San Andreas rift, as this fissure has been called, lies just west of San Francisco, and its course is marked on sheet 13 (p. 90).

The cracks in the soil that mark the line of the last displacement (Pl. XXXIII, $B$, p. 127) and the parallel ridges and valleys that show older displacements along the fault zone are well displayed in Spring

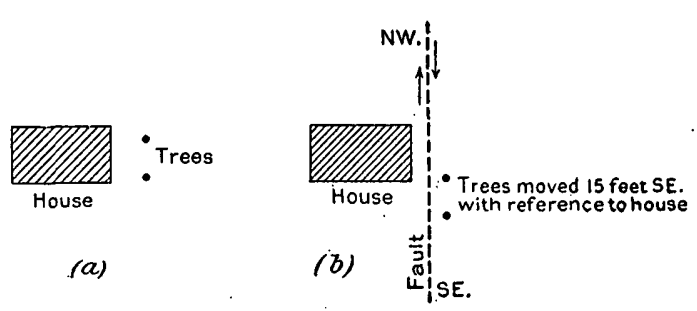

FIGURE 12.-Earthquake effects at Skinner's ranch, near Olema, Cal. The relative position of the ranch house and trees on opposite sides of the fault plane shows that the horizontal movement was about 15 feet. $a$, Before earthquake; $b$, after earthquake.

Valley, 13 miles south of San Francisco, and especially near Skinner's ranch, 40 miles northwest of San Francisco.

To reach Spring Valley the visitor should take a Southern Pacific train to San Mateo (18 miles), where a conveyance may be obtained for a drive through Spring Valley along Crystal Spring and San Andreas lakes.

Skinner's ranch can be reached by the ferry to Sausalito and the Northwestern Pacific Railroad to Point Reyes station, from which the ranch is only 2 miles distant, near Olema. In this region may be seen best the earth cracks along the fault line. Near the ranch house there is striking evidence of the horizontal character of the movement that produced the earthquake. The house formerly had two trees in front of it. The fault line, which trends northwest, passes between the trees and the house, and the trees were moved 15 feet to the southeast with reference to the house. (See fig. 12.) There was no perceptible vertical movement nor any change in the water line along Tomales Bay. 


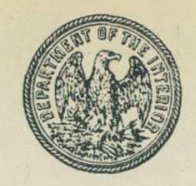

GEOLOGIC AND TOPOGRAPHIC MAP ОF тнЕ

\section{SHASTA AND COAST ROUT:S}

From Seattle, Washington, to San Francisco, Califrnia From Los Angeles, California, to San Francisco, Cafornia Base compiled from United States Geological Survey Atlas Sheets, from railroad alignments and profiles supplied by
the Southern Pacific Company and from additional inform the Southern Pacific Company and from addition
tion collected with the assistance of this company

UNITED STATES GEOLOGICAL SURVH GEORGE OTIS SMITH, DIRECTOR David White, Chief Geologist $\quad$ R. B. Marshall, Chief Geographer 1915

Each quadrangle shown on the map with a name in parenthesis in the lower left corner is
Sheet of that name.
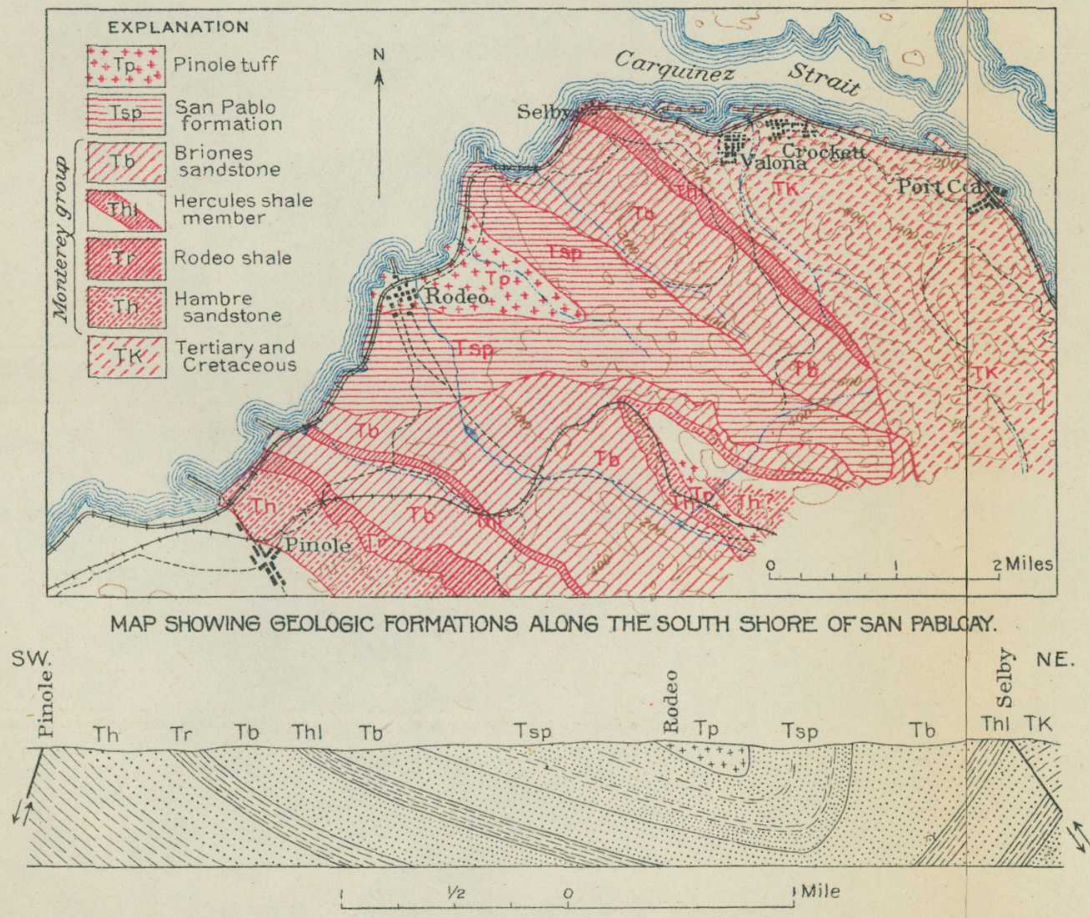

SECTION SHOWING STRUCTURE ALONG THE SOUTH SHORE OF SAN PABLO BAY

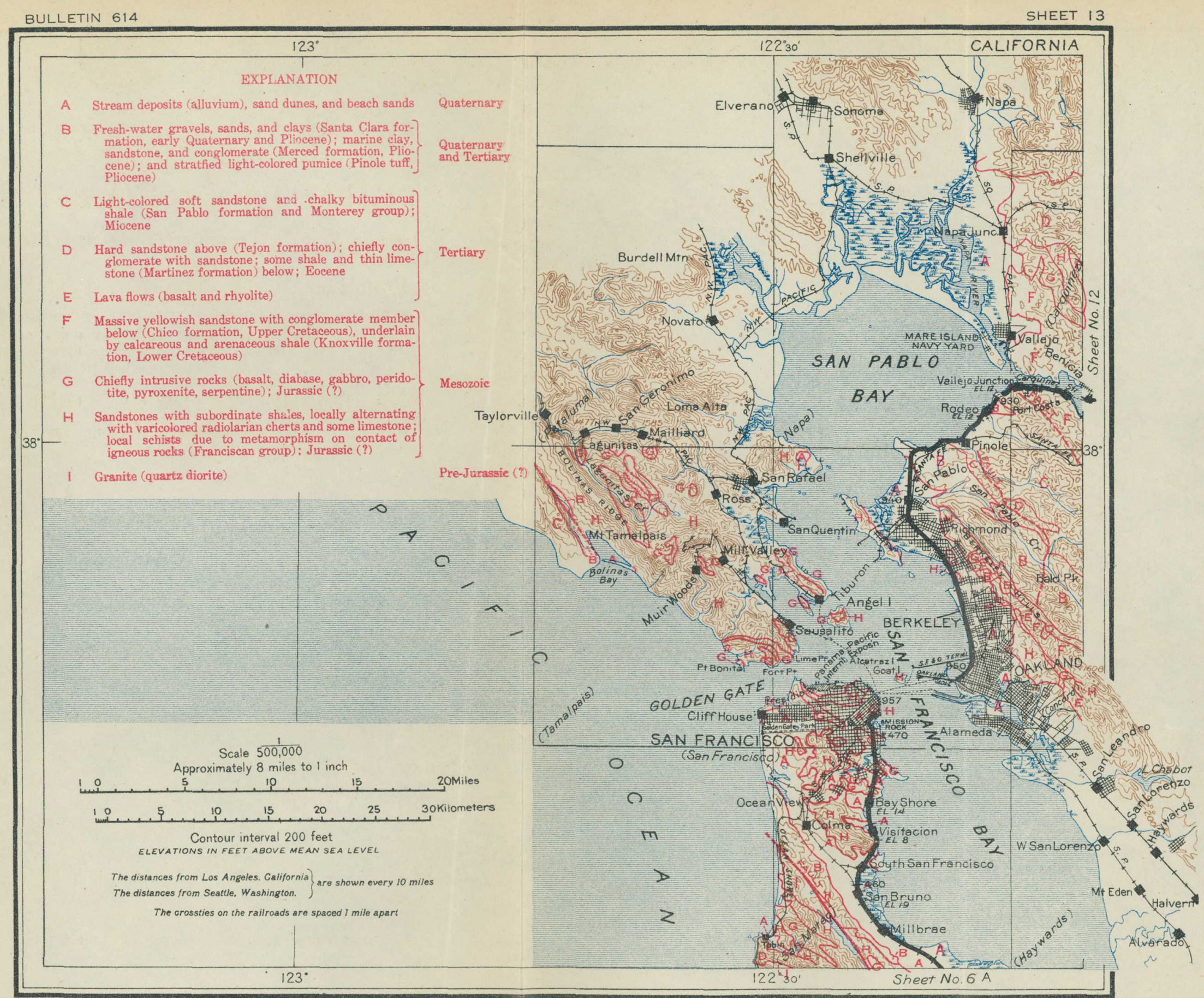




\section{COAST LINE.}

\section{LOS ANGELES TO SAN FRANCISCO.}

Los Angeles (Spanish pronunciation, loce ahn'hay-lace) is the metropolis of the Southwest and is preeminently a city of homes. It lies on Los Angeles River (see sheet 1A, p. 102) only 15

Los Angeles.

Elevation 293 feet. Population 319,198. miles from the sea and is built on a series of broad steplike terraces which, although now from 250 to 500 feet above sea level, were probably in part carved by the waves of the ocean. The situation of these terraces and their equable climate (mean temperature, January $54^{\circ}$, August $72^{\circ}$ ) have made Los Angeles and its sister city, Pasadena, two of the most attractive home cities in the world.

The Pueblo de Nuestra Señora la Reina de los Ángeles (city of Our Lady the Queen of the Angels) was founded by the Spaniards in 1781, and the Plaza Church marks the site of the old village. It 'became an American possession in 1846 but attracted little attention until the transcontinental railways were built. In 1885, although a century old, Los Angeles was still a town of adobe houses with but few more than 11,000 people. The opening of this delightful region brought floods of settlers. In 1900 it had a population of 102,479 , and in 1910 this had more than trebled. A city census taken in June, 1915 , indicated a population of 528,000 . The residential portion of the city is noted for its many beautiful mansions embowered in semitropical bloom and verdure. The rapidly growing eucalyptus, from Australia, and the graceful pepper tree, from Peru, with palms, native and foreign, are the most abundant trees in the streets and parks. Although largely residential, the city has over 2,300 factories, whose output in 1913 was valued at more than $\$ 157,000,000$.

The water supply is excellent and is brought by an aqueduct from Owens Valley, 226 miles away. For the building of this aqueduct across the desert and through the mountains $\$ 23,000,000$ in bonds were issued.

Los Angeles is in the heart of the fruit-growing region of southern California. The surrounding plains and valleys are covered with vineyards and orchards-olives, oranges, and lemons. The shipment of citrus fruit from the region in the season of 1913-14 amounted to 40,000 carloads.

In Los Angeles and vicinity there are about 50 moving-picture studios, representing an investment of several million dollars. This region is said to be the center of the world's film-producing industry.

1 A large part of the material relating to the route between Los Angeles and Watsonville Junction has been furnished by Mr. Ralph Arnold. 
The Museum of History, Science, and Art is one of the most interesting places in the city. It has fine collections in many branches, exhibited in an attractive and instructive manner. The museum authorities control the wonderful bone deposits (Pl. XXV, $B$ ) in the asphalt springs of Rancho La Brea, about 8 miles directly west of the city. These springs have been for centuries the most effective natural animal trap known, and the asphalt has preserved the bones of the thousands of animals caught in its deceptive and sticky pools. The skeletons of elephants, camels, sloths, saber-toothed tigers, bears, and myriads of smaller animals, including many birds, are being gradually dug out and set up in the museum (Pl. XXV, $A$ ). Among the bones has recently been found the skull of a human being who lived probably not less than 10,000 years ago, contemporaneously with many animals now extinct.

In the northern part of the city is a belt of oil-producing territory $5 \frac{1}{2}$ miles long, covering an area of 2 square miles. Hzre hundreds of derricks have been erected in close proximity to dwellings. ${ }^{1}$

\footnotetext{
${ }^{1}$ The following notes are based on a concise account of the geology and technology of the California oil fields by Ralph Arnold and V. R. Garfias.

The production of petroleum in California is the most important mineral industry in the State, the annual value of the oil output equaling that of all the metals. Since 1903, with the exception of 1907 and 1908, California has annually produced more petroleum than any other State in the Union, and in 1914 the production was over $100,000,000$ barrels.

The most productive fields are in the southern part of the great San Joaquin Valley, which lies in the central part of the State, and in the region along the coast from the vicinity of Los Angeles to a point a little north of Santa Barbara County (fig. 13).

Oil is found in commercial quantity in geologic formations ranging in age from Cretaceous to Quaternary. The principal formations are shown in the table on page 94 , the oldest at the bottom, the youngest at the top. All these formations are not present in any one region, and the thicknesses given are rough estimates.

in southern California the oldest formation containing oil in commercial quantities is the Topatopa (Eocene), from which wells in Simi Valley and at a few places in the Santa Clara River valley obtain oil. The oil so far produced from this formation is small in amount but it is very light and brings a higher price than any other oil in California.

The shale of the upper part of the Monterey group (Miocene) is the principal source of oil in California and has yielded oil in the Santa Maria, Santa Clara, and Puente Hills districts. The gravity of the oil ranges from $12^{\circ}$ to $35^{\circ}$ Baumé. This shale is made up largely of the remains of diatoms-minute aquatic plants composed of a jelly-like substance surrounded by a shell of silica. Only the hard shells are now visible. They may be seen with a strong magnifying glass in the earthy varieties of this shale, the more common forms appearing as flat disks which look like minute percussion caps. The soft matter is believed to have been changed into petroleum. Besides the diatoms the shale contains the shells of minute animal forms called foraminifers, the soft matter from which probably also formed part of the petroleum. The oil formed from these animals and plants has moved into the sandy beds interstratified with the shale, where it fills the spaces between the sand grains; or into the cracks and joint planes in the hard and flinty shale itself.
} 


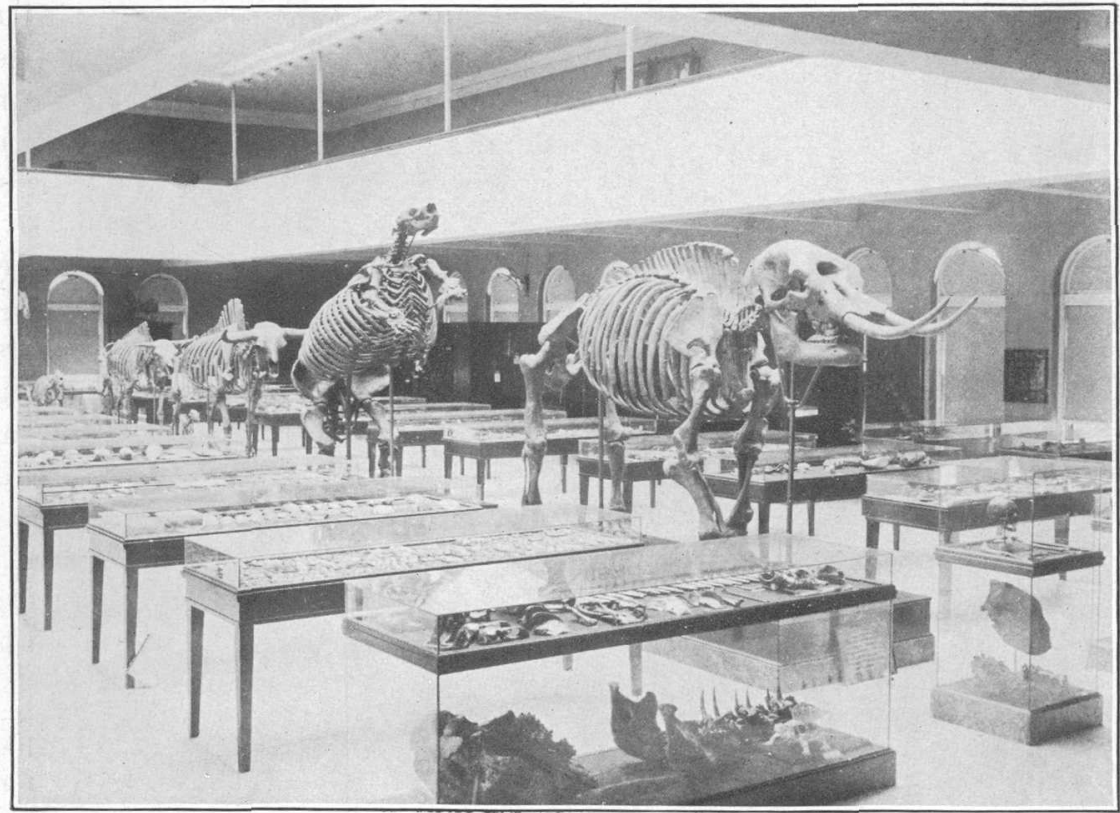

A. LA BREA WING OF THE MUSEUM OF HISTORY, SCIENCE, AND ART AT LOS ANGELES, CAL.

The restored forms, in order from front to rear, are the mastodon (Mammut americanum), giant ground sloth (Mylodon), ancient $\mathrm{x}$ or bison (Bos antiquus), male and female, and saber-toothed tiger (Smilodon californicus).

In the case in front of the mastodon is the only human skull yet found in the deposits.

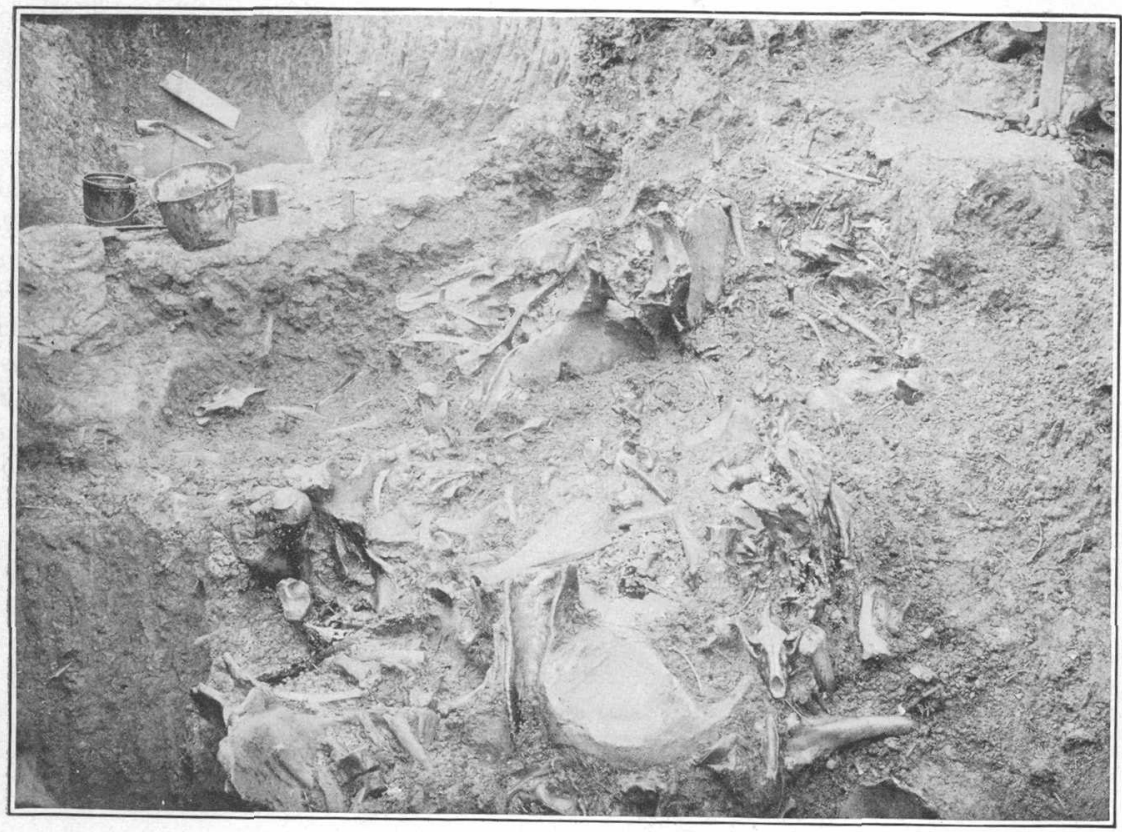

B. FOSSIL BONES IN ASPHALT DEPOSIT OF RANCHO LA BREA, NEAR LOS ANGELES, CAL. 
With the permission of the Museum of History, Science, and Art the Rancho La Brea may be visited. On the way thither the traveler passes over a portion of the great alluvial plain of Los Excursions from Los Angeles, which is underlain, at least in part, by three
Angeles.

Quaternary formations, the oldest of which is a marine deposit laid down horizontally on the beveled edges of a very thick series of tilted Pliocene beds. This marine Quaternary deposit has a thickness of 100 feet in the northwestern part of the city but thins to an edge near the ancient sea cliff beyond. Los Angeles River exca-

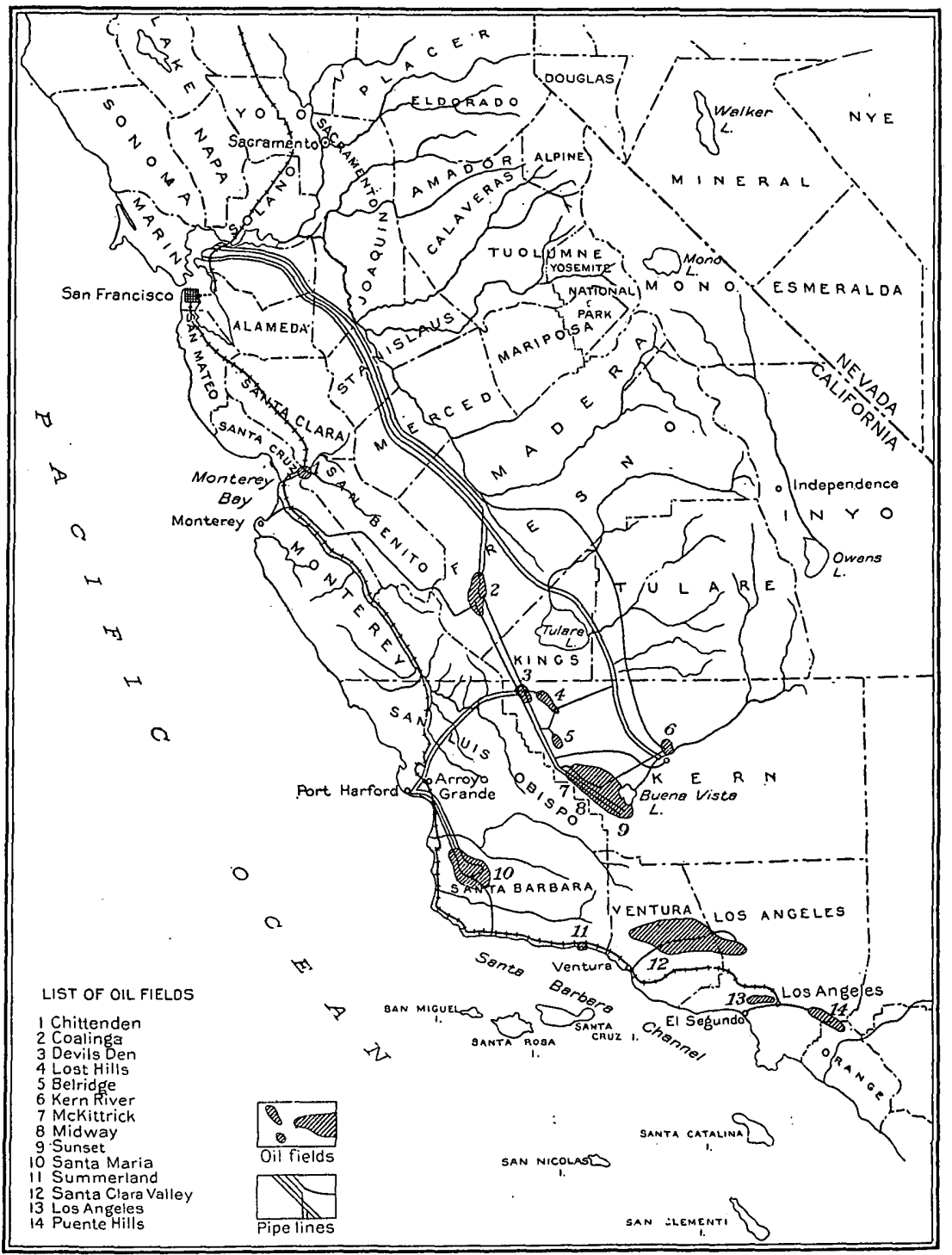

FIGURE 13.-Map showing the oil fields of California. 
vated a valley about a mile wide and 100 feet deep in the marine deposit and filled the trench with river deposits, the second Quaternary formation. This in turn is covered by the alluvium of the present plain.

Geologic formations in the oil fields of the coastal region of southern California.

\begin{tabular}{|c|c|c|c|c|c|c|}
\hline Era. & $\begin{array}{l}\text { System or } \\
\text { period. }\end{array}$ & $\begin{array}{l}\text { Series or } \\
\text { epoch. }\end{array}$ & \multicolumn{2}{|c|}{ Group or formation. } & $\begin{array}{l}\text { Approxi- } \\
\text { mate } \\
\text { thickness, } \\
\text { in feet. }\end{array}$ & $\begin{array}{l}\text { Quantity of oil and } \\
\text { quality (Baumé). }\end{array}$ \\
\hline \multirow{7}{*}{ 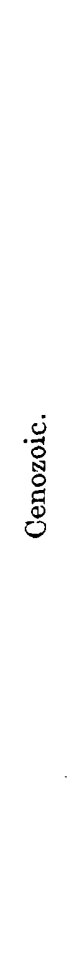 } & \multirow{2}{*}{$\begin{array}{l}\text { Quate:- } \\
\text { nary: }\end{array}$} & Recent. & \multicolumn{2}{|c|}{ Alluvium, terrace deposits. } & 1,000 & \\
\hline & & $\begin{array}{l}\text { Pleisto- } \\
\text { cene. }\end{array}$ & \multirow{2}{*}{\multicolumn{2}{|c|}{$\begin{array}{l}\text { Fermando } \\
\text { formation. } \\
\qquad \begin{array}{l}\text { Pismo and Sant: } \\
\text { Margarita for- } \\
\text { mations. }\end{array} \\
\text {-Unconformity }\end{array}$}} & 1,000 & \\
\hline & \multirow{5}{*}{ Tertiary. } & Pliocene. & & & $\begin{array}{l}7,000 \\
2,000\end{array}$ & $\begin{array}{l}\text { Also asphal- } \\
\text { tum. }\end{array}$ \\
\hline & & Miocene. & $\begin{array}{l}\text {-Unconformity- } \\
\text { Monterey group } \\
\text { Vaqueros san }\end{array}$ & $\begin{array}{l}\text { including } \\
\text { stone. }\end{array}$ & 10,000 & Oil; $12^{\circ}-35^{\circ}$ \\
\hline & & $\begin{array}{l}\text { Oligo- } \\
\text { cene. }\end{array}$ & \multicolumn{2}{|l|}{ Sespe formation. } & 4,300 & $\begin{array}{l}\text { Good oil; } 26^{\circ}- \\
36^{\circ} \text {. A } 1 \text { s o } \\
\text { some heavier } \\
\text { oil. }\end{array}$ \\
\hline & & \multirow{2}{*}{ Eocene. } & Tejon formation. & \multirow{2}{*}{$\begin{array}{l}\text { Topatopa } \\
\text { for ma- } \\
\text { tion. }\end{array}$} & 5,000 & \multirow{2}{*}{$\begin{array}{l}\text { Some high-grade } \\
\text { oil; lower oil } \\
\text { horizon. }\end{array}$} \\
\hline & & & $\begin{array}{l}\text { Martinez for- } \\
\text { mation. }\end{array}$ & & 4,000 & \\
\hline \multirow{3}{*}{ 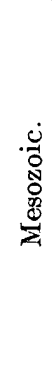 } & \multirow{2}{*}{$\begin{array}{l}\text { Creta- } \\
\text { ceous. }\end{array}$} & $\begin{array}{l}\text { Upper } \\
\text { Creta- } \\
\text { ceous. }\end{array}$ & \multicolumn{2}{|l|}{ Chico formation. } & 4,000 & \\
\hline & & $\begin{array}{l}\text { L ow e r } \\
\text { Cretaceous } \\
\text { or Shasta. }\end{array}$ & \multicolumn{2}{|c|}{ Knoxville formation. } & $3,000 \pm$ & $\cdot$ \\
\hline & Jurassic? & & \multicolumn{2}{|c|}{ Franciscan group. } & $1,000 \pm$ & - \\
\hline 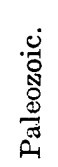 & & & \multicolumn{2}{|c|}{$\begin{array}{l}\text { Schist and limestone in- } \\
\text { truded by granite. }\end{array}$} & $?$ & \\
\hline
\end{tabular}


Other excursions may be made to the coast at Long Beach (south, 21 miles), Santa Monica (west, 17 miles), Redondo (southwest, 23

The Fernando and its equivalent postMonterey formations contain the most important oil reservoirs in the State, owing in great measure to their unconformable position upon the underlying Monterey group, which has facilitated the upward migration of the oil originating in the Monterey. In general the Fernando sediments consist of more or less incoherent conglomerates and sands, clayey shales, and soft clays. With some exceptions the oil produced by the Fernando is of the fuel type, its gravity ranging from $11^{\circ}$ to $19^{\circ}$ Baumé. Large deposits of asphaltum, the residuum from oil escaping into the Fernando from the Monterey group, occur at a number of places.

The oil in the California fields, as in most others throughout the world, occurs in inclined or sloping beds of porous sand, and these oil sands are usually overlain and underlain by water sands, which are separated from the oil sands by impervious clay, shale, or other strata.

The principal oil fields adjacent to Los Angeles are those of the Los Angeles district and the Puente Hills district. The Los Angeles district includes the City - field, lying in the city of Los Angeles, and the Salt Lake field, immediately west of the city limits, about $4 \frac{1}{2}$ miles from its business center.

The City field was discovered in 1892 , when a 155-foot shaft was sunk near a small deposit of brea on Colton Street. The first successful well was drilled later in that year on Second Street, and by the end of 1895 there were more than 300 wells. This field forms a narrow belt about $5 \frac{1}{2}$ miles long running through the northern part of the city; the total area is about 2 square miles. The wells are from 500 to 1,200 feet in depth, and the gravity of the oil ranges from $12^{\circ}$ to $19^{\circ}$ Baumé. The limits of the field are well defined. The wells have always been small producers, necessitating pumping, and owing to the greatnumber of wells drilled within a small area the field has been drained at a rapid rate and water has been allowed to enter the oil sands in many areas.

The first well in the Salt Lake field was drilled in 1901 by the Salt Lake Oil Co., and since 1902 this field has been the chief producer in the Los Angeles district. The wells are deeper than in the City field, ranging between 1,200 and 3,000 feet, and the average gravity of the oil is between $16^{\circ}$ and $18^{\circ}$ Baumé. Considerable gas under strong pressure accompanies the oil, which causes the wells to gush during the early part of their life.

The oil in the Los Angeles district is derived largely from the upper 500 feet of the Monterey group and the basal beds of the Fernando formation. During 1914 the district produced about 2,500,000 barrels of oil, and between 1894 and the end of 1914 it produced over 40,000,000 barrels. At present there are about 700 producing wells in the district. The average daily production for each well in the City field is about $2 \frac{1}{2}$ barrels and in the Salt Lake field about 23 barrels.

The oils of the City field are uniform in quality, although they vary considerably in gravity. They contain considerable sulphur, and owing to the entire absence of light products are of little value for refining, being used almost entirely for fuel. The oils produced in the Salt Lake field show a marked similarity in general properties, being characterized by a high percentage of sulphur. The heavy oils are highly viscous and yield considerable asphalt.

The Puente Hills district, from 12 to 34 miles southeast of Los Angeles, was the second oil district discovered in California. The first producing well in it was completed in 1880. Until 1893 the Puente Hills and Santa Clara River Valley districts yielded practically all the oil produced in California. The average depth of the wells in the Puente Hills district is somewhat more than 1,300 feet and the average life of the wells is about 16 years. The gravity of the oil varies between $21^{\circ}$ and $32^{\circ}$ Ballmé. 
miles), and San Pedro (south, 22 miles). San Pedro is the chief harbor of Los Angeles and is being greatly improved by the Federal Government. San Pedro Mountain, northwest of the town, has a core of older igneous rocks encircled by Tertiary beds. The slope of the hill is scored by a series of horizontal terraces suggestive of great steps. These were cut by the ocean waves when the land stood at lower levels. Deadman Island, near San Pedro, is one of the best localities on the Pacific coast to collect Pliocene and Pleistocene fossils.

From San Pedro steamers ply to Santa Catalina, ${ }^{1}$ a mountainous island composed chiefly of Franciscan (Jurassic?) rocks. The sea fishing here is famous, and through the crystal-clear water the sea bottom and the plants and animals that inhabit it may be seen from glass-bottomed boats.

About 9 miles east of Los Angeles is San Gabriel Mission, founded in 1771 , and near by is the interesting church erected in 1804 of material brought from Spain. Pasadena is easily reached by train or electric car. Trips likely to prove more interesting to lovers of nature or science are those to Mount Lowe and Mount Wilson. These summits belong to the San Gabriel Mountains, which present an abrupt face on the north side of. the San Gabriel Valley. They are composed of granitic and other crystalline rocks which contain gold and other precious metals.

Mount Lowe $(5,650$ feet above sea level) is reached by the Pacific Electric Railroad from Los Angeles to Echo Canyon. From the canyon a cable railway runs over a 1,000-foot ascent to the summit of Echo Mountain ( 4,015 feet), where connection is made with a mountain railway for Alpine Tavern (5,000 feet). A trail leads from the. tavern to the summit, from which a fine view may be obtained. The mountain mass is composed chiefly of granitic rocks, which by their disintegration have furnished much sedimentary material for the Tertiary deposits of the foothills and adjacent lowlands.

Mount Wilson (5,750 feet) may be ascended afoot or on burros from Sierra Madre (mah'dray), a station on the electric tramway.

The lighter grades of oil are believed to come from the Monterey group; the heavier grades are derived largely from the coarser sediments of the Fernando.

On December 31, 1912, there were 470 producing wells in the Puente Hills district, and the output for the year was nearly $7,000,000$ barrels. The total production of the field from 1889 to 1912 , inclusive, was nearly 41,000,000 barrels. The oil produced varies in composition, the greater part being of light grade and utilized by refineries near Los Angeles.
1 The topography of Santa Catalina - Island presents a striking contrast to that of the neighboring mainland and to that of San Clemente Island, which lies farther out in the ocean. The mainland and San Clemente Island show old beach lines and sea terraces standing high above the present shore and have therefore risen, but Santa Catalina Island shows no such markings; on the contrary, as Prof. A. C. Lawson has pointed out, this island presents unmistakable evidence of having subsided. 
At the top is the solar observatory of the Carnegie Institution. The view is extensive and very beautiful. The rocks, like those of Mount Lowe, are highly crystalline. Hotels on the summit and northern slope make it possible to remain overnight on the mountain.

The great Los Angeles plain, on which the main part of the city of Los Angeles is built, has been trenched by the streams that cross it in a succession of steps or terraces. As the train leaves the Arcade Station the principal river terrace can be seen on the left by looking up some of the streets, particularly Main Street just below the Plaza.

Passing northward and eastward from the business portion of the city the train goes through the Southern Pacific Railroad yards, across which, to the left, can be seen the tops of the derricks at the east end of the City. oil field. The oil wells were drilled close together in the residence portion of the city and, although many of the derricks have been removed, enough are left to attract attention.

North of the railroad yards the main line runs along Los Angeles River for half a mile. The river here cuts across the beds on the south flank of the main arch or anticline of the City oil field and exposes a fine section of the Miocene sandstone (Monterey) along its west bank. The beds dip south at angles ranging from $20^{\circ}$ to $50^{\circ}$. About 472 miles from San Francisco the line crosses Los Angeles River opposite Elysian Park (on the hill to the left). The railroad continues up the eaist bank past fine orchards and berry farms. The hills to the right (east) are composed largely of the Miocene sandstone, folded into one or more well-developed anticlines. Farther north and east shales of Miocene (Monterey) age overlie these sandstones and form the rolling hills between Los Angeles and Pasadena.

The prominent peak to the left (west) of the railroad, opposite Tropico, is Cahuenga (ca-wain'ga) Peak (elevation 1,825 feet), of the Santa Monica Range. It consists largely of Tropico.

Elevation 434 feet. Los Angeles 6 miles. granitic rocks, but north of the peak a thick coarse conglomerate lies against the granite. South of the peak are flows and dikes of dark lava (basalt) and sandstones and shales of the Monterey group.

It is believed that south of Cahuenga Peak there is a strong fissure (fault) along which the rocks on the south side have sunk or those on the north side risen. This fault probably extends westward along the base of the Santa Monica Range, of which Cahuenga Peak is the easternmost point. The central mass of the range consists largely of gneiss and black schist. Cretaceous and Tertiary rocks flank this crystalline core farther west, in the region north of Santa Monica. $96286^{\circ}-$ Bull. $614-15-7$ 
Between Tropico and West Glendale the San Gabriel Range, rising from 2,000 to 3,000 feet above the valley, may be seen on the right (north). This range consists entirely of granitio West Glendale. and gneissoid rocks. Structurally it is a great block Los Angeles 8 miles. that has been lifted up along a well-defined fault which extends along the south base of the range from the region of West Glendale to the vicinity of Eagle Rock, just west of Pasadena. Eagle Rock, at the east end of the Eagle Rock Valley, which can be seen from the railroad in the vicinity of West Glendale, is an old landmark composed of a locally hardened mass of Miocene (Monterey) conglomerate. The "eagle" on the side of the rock is caused by shadows cast by overhanging portions of the conglomerate. The fault is very pronounced in the vicinity of Eagle Rock, where in consequence of it the conglomerate beds on the south dip steeply toward the granitic mass on the north, although of course they are cut off at the fault and do not go under the granite.

At Burbank the Coast Line turns off westward from the Valley Iine and enters San Fernando Valley, noted for its large production

\section{Burbank.}

Elevation 555 feet.

Los Angeles 12 miles. of hay and fruit. South of Burbank, in the little valley at the northeast foot of Cahuenga Peak, on the edge of San Fernando Valley, is Universal City, the only city in the world built solely for the production of moving-picture film. This magic place can be changed in a few days to get any scene or setting desired-Athens, Rome, London, Paris, New York, Hindu streets, Afghan villages, all with true local color. Ten miles of film can be made here in a week. The city contains 3,000 . or 4,000 persons, employees of the picture company, and a zoo comprising several hundred wild animals.

The Monterey beds on the north flank of the Santa Monica Range, south of the railroad, are intruded by basalt dikes and associated with flows of the same lava. Overlying the Monterey, and deposited later than the basalt flows, is the Fernando formation, consisting of conglomerates, sandstones, and soft shales, which dip toward the valley. The Fernando beds also flank the eastern extremity of the San Fernando Hills north of the San Fernando Valley. This formation is full of fossil shells and other marine organisms, which indicate upper Miocene, Pliocene, and Pleistocene age.

About 3 miles west of Burbank the railroad crosses Tujunga (toohoon'ga) Wash, which marks the underground channel of a tributary to Los Angeles River. This phenomenon of underflow is characteristic of the arid and semiarid regions of the Southwest. Several mountain streams unite in forming Tujunga River, which debouches from the mouth of a canyon into Tujunga Wash. The water immediately sinks out of sight and flows through coarse gravels and sands under the plain until it reaches the hard rocks north of Cahuenga 
Peak, where it rises in springs and enters Los Angeles River, a perennial stream which supplied the city of Los Angeles with water until the Owens River supply became available. Many legal contests have arisen over the efforts of the people owning the land along Tujunga Wash to sink wells into the subterranean river, but the courts have held that the right of the city of Los Angeles to this water is as well founded as if the river flowed on top of the ground. Very little water flows over Tujunga Wash except during certain parts of the rainy season. Passengers often wonder why the railroad builds long trestles across apparently dry, cactus-covered desert, but during the torrential rains which occur every few years the wash becomes a raging torrent. Settlers who are not familiar with the characteristics of such washes are often robbed of their entire land holdings by changes of channel.

At milepost 457 the railroad crosses the pipe line from Owens River.

The traveler looking eastward from San Fernando Valley obtains a good view of the west end of the San Gabriel Range, which extends from the low Fernando Pass, utilized by the Valley Line of the Southern Pacific, eastward to Cajon Pass, north of San Bernardino, a distance of 70 miles. The culminating peak in the eastern portion of the range is Old Baldy, 10,080 feet in elevation. This peak, often snowcapped, is visible from Los Angeles. The western end of the range, including Mount Wilson and Mount Lowe, is lower, rising only to a general elevation of 3,000 to 4,000 feet. Some sedimentary beds of the Fernando formation flank the granitic rocks at the west end of the range and are faulted into contact with these rocks on the south. On a clear day the sedimentary rocks can be easily distinguished from the granites by their yellow color.

At milepost 455 the Pacific Electric Railway track is crossed. On Raymer.

Elevation 783 feet. Los Angeles 21 miles.

the left in the distance from Raymer station is the large white schoolhouse at Van Nuys, a town on a branch line of the Southern Pacific that runs through an agricultural district south of the Coast Line and nearer the river.

Zelzah is the great hay center of the San Fernando Valley. The region yields about 40,000 tons annually, of which 95 per cent is

Zelzah.

barley hay. Much fruit is also raised in the valley, the orchards being irrigated by pumping ground Los Angeles 25 miles. water. As the road approaches the west end of the San Fernando Valley the most prominent elevation to the left is Saddle Peak, the name being suggested by the obvious similarity of the mountain top to a saddle. The rocks here are very resistant sandstones and the crest of the ridge is rugged and almost inaccessible. The Santa Susana Range bounds the north side of this part of the valley. 
To a geologist one of the most impressive sights of the whole trip from Los Angeles to San Francisco is the great escarpment of thickbedded Eocene sandstones which blocks the west Chatsworth. end of the San Fernando Valley. From the east the Elevation 952 feet. beds are seen to lie one on top of another to a height Population 299.*
Los Angeles 29 miles. of nearly 1,200 feet above the valley. The continuaLos Angeles 29 miles. tion of these beds, whose edges are thus visible, lies under the San Fernando Valley, and the escarpment indicates a great break in the earth's crust along which the rocks on the northwest side have been heaved up or those on the southeast side have sunk. In other words, the steep slope that closes the west end of the valley is a fault scarp. The faulting took place many hundreds of years ago and the cliff has, of course, since been modified by the action of water and air. This great fault extends from the southwest corner of the valley in a north-northeasterly direction into the Santa Susana Mountains. The Eocene sandstones are eroded into grotesque shapes, some of them suggestive of battlements rising steeply above the railroad.

Sandstone from the Topatopa formation (Eocene) quarried 2 miles northwest of Chatsworth is utilized for the San Pedro Breakwater and also as a building stone.

After passing through two tunnels which penetrate minor ridges the railroad goes through a tunnel, 7,369 feet long, about 500 feet below the Santa Susana Pass. The line between Los Angeles and Ventura counties is crossed midway of this tunnel. The Eocene beds (Topatopa) dip west at a rather low angle, so that the tunnel, from east to west, cuts successively younger or higher beds in the formation. Soon after leaving the tunnel, the train goes through some cuts of coarse Eocene conglomerate which overlies the beds just described. These rocks form the east end of Simi (see'me) Valley, which comes into view as the train proceeds westward beyond the tunnel.

Although the Eocene series here is more than 3,000 feet thick, the dip of the beds to the west soon carries them out of sight under the younger formations. The rocks immediately overSanta Susana. lying the coarse Eocene sandstone and conglomerate Elevation 964 feet.
Los Angeles 37 miles. Los Angeles 37 miles. the Sespe formation. On the north (right) side of the valley, opposite milepost 436 , oil derricks of the Newhall field are seen in the distance near the base of some low hills lying in front of the main Santa Susana Range. These derricks mark the position of wells that penetrate the uppermost beds of the Eocene (Topatopa formation), on the flanks of a well-developed arch or anticline in these beds. The anticline extends eastward along the base of the hills. The wells range in depth from 300 to 1,800 feet and yield from 5 to 200 barrels each daily of $37^{\circ}$ Baumé oil, the best oil in the State. 
The light-colored beds showing low in the hills behind the derricks belong to the Sespe formation (Oligocene). Above them are darker beds belonging to the Vaqueros sandstone (lower Miocene). The very lightest beds at the top are the Monterey shale (Miocene). A full sequence of the formations is found in some of the canyons running northward from the Simi Valley to the crest of the range.

The hills immediately south of the town of Santa Susana consist of the rusty beds of the Sespe (Oligocene) formation. Farther back are the underlying Topatopa (Eocene) beds. Still farther south the Santa Monica Range consists of a thick series of Cretaceous sedimentary rocks cut by complicated masses of igneous rocks, largely of Miocene age.

The Simi Valley, like the San Fernando Valley, owes its existence and general form to the folding and faulting of the rocks-that is, it is essentially a structural valley and not wholly or chiefly the work of erosion. It is filled with alluvium to an unknown depth. On the north side of the valley a well-defined sag in the strata (a syncline) underlies the line of hills between the crest of the nearest range and the crest of the most northern range visible. This northern range forms the south side of Santa Clara Valley ${ }^{1}$ from Saugus to Ventura. On both sides of that valley are productive oil fields that yield petroleum ranging from a heavy, tarry oil to an oil of very light gravity that is much sought after by the refiners of illuminating oil. ${ }^{2}$

\footnotetext{
1 There are at least two Santa Clara valleys in California-one in Ventura and Los Angeles counties, drained by Santa Clara River, and the well-known fertile lowland just south of San Francisco Bay, in Santa Clara County. The traveler from Los Angeles to San Francisco passes through parts of both of these valleys and should keep the distinction in mind.

2 The Santa Clara district is the oldest oil-producing territory in the State, the first oil being obtained here about 48 years ago from tunnels driven near Ventura and on the south flank of Sulphur Mountain. The first productive well in California was drilled near Ventura in 1867. The district includes the region on both sides of Santa Clara River from the Newhall field, in Los Angeles County, 40 miles northwest of Los Angeles, to the Ojai Valley field, in Ventura County, about 50 miles farther west. The Santa Clara district produced practically all the oil in the State up to 1880, when the Puente Hills district was discovered. The bulk of the production is of refining grade. The yield in 1913
}

was $1,042,348$ barrels, most of which was piped to seaboard.

The district comprises 13 fields, some of which are in almost inaccessible places, the productive territory being confined to very narrow strips along the crests of sharp folds. The wells range in depth from 200 to 3,700 feet, a large number being less than 1,000 feet deep. It is estimated that the average depth of the wells is less than in any other district in the State.

The heaviest oil, ranging from $11^{\circ}$ to $16^{\circ}$ Baumé, is found in the Ojai Valley, Hopper Canyon, and Elsmere Canyon fielde. Practically all the other fields yield refining oil ranging from $23^{\circ}$ to $38^{\circ}$ Baumé. The wells vary greatly in capacity, some having an initial flow of 500 to 600 barrels a day and some being profitably operated for a yield of 2 barrels a day or even less. It is estimated that the average daily production per well for the entire district in 1913 was 7.2 barrels.

Although practically all the fields have been operated for many years, the territory is by no means all prospected, and 
A stratigraphic arch, the Simi anticline, crosses the mouth of Tapo Canyon from east to west, extends westward for 2 or 3 miles, and then gradually swings toward the southwest, crossing Simi.

Population 748** Los Angeles 42 miles. the west end of the Simi Valley. The hills which limit this valley on the west have been carved by erosion from the upfolded beds of this anticline. The beds on the north flank of the anticline are well exposed in the hills northwest of the valley.

From the town of Simi the railroad follows Arroyo Simi to Moorpark. The rocks exposed in the cuts along the arroyo (Spanish for small stream) are chiefly conglomerates and sandstones of the Sespe (Oligocene) formation. The same rocks also compose the low hills on both sides of the track as far as one can see.

An old terrace is visible on the north side of the track at the head of the Little Simi Valley, north of the village of Moorpark. This terrace was probably formed at the same time as Moorpark.

Elevation 511 feet. Los Angeles 48 miles. some of the marine terraces on the coast, though it is doubtless due to stream erosion and not to waves. Moorpark is a center for barley, hay, dried fruit, and beans. Water for irrigation is pumped from Little Simi Creek. West of Moorpark the rocks of the Fernando formation form low hills on both sides of Little Simi Valley. The high hills farthest north, including Oak Ridge, consist of the Vaqueros and higher beds of the Monterey group, which here have an anticlinal structure. Remnants of the old river terrace appear along the south side of Litile Simi Valley for 2 or 3 miles below Moorpark, and near the west end of the valley suggestions of other less prominent terraces are seen on both sides. Little Simi Valley owes its form partly to structure but largely to erosion.

From Ternez and Lagol, in the western part of the Little Simi Valley, fine distant views may be had to the right (north) of San Cayetano Mountain (4,122 feet), which lies beyond Oak Ridge and Santa Clara River, just west of Sespe Canyon. The mountain consists largely of Eocene (Topatopa) and overlying Oligocene (Sespe) beds. Its southern slope is a fault scarp modified by erosion.

North and west of San Cayetano Mountain are visible the Topatopa Mountains, a prominent range in the Santa Barbara National Forest. This range is the eastern extension of the Santa Barbara and Santa

additions to the productive areas are being made from time to time.

The formations involved in the geology of the district include a basal complex of granitic and gneissic rocks, on which rest the Topatopa, Sespe, Vaqueros, Monterey (upper part), and Fernando sedimentary formations. All these sedimentary for- mations contain oil, but the Sespe is the most productive.

The production of the Santa Clara district in 1870 was 3,600 barrels. The production in 1913 was $1,042,348$ barrels, and the total production of the district, including that of 1913 , has been $16,139,943$ barrels. 


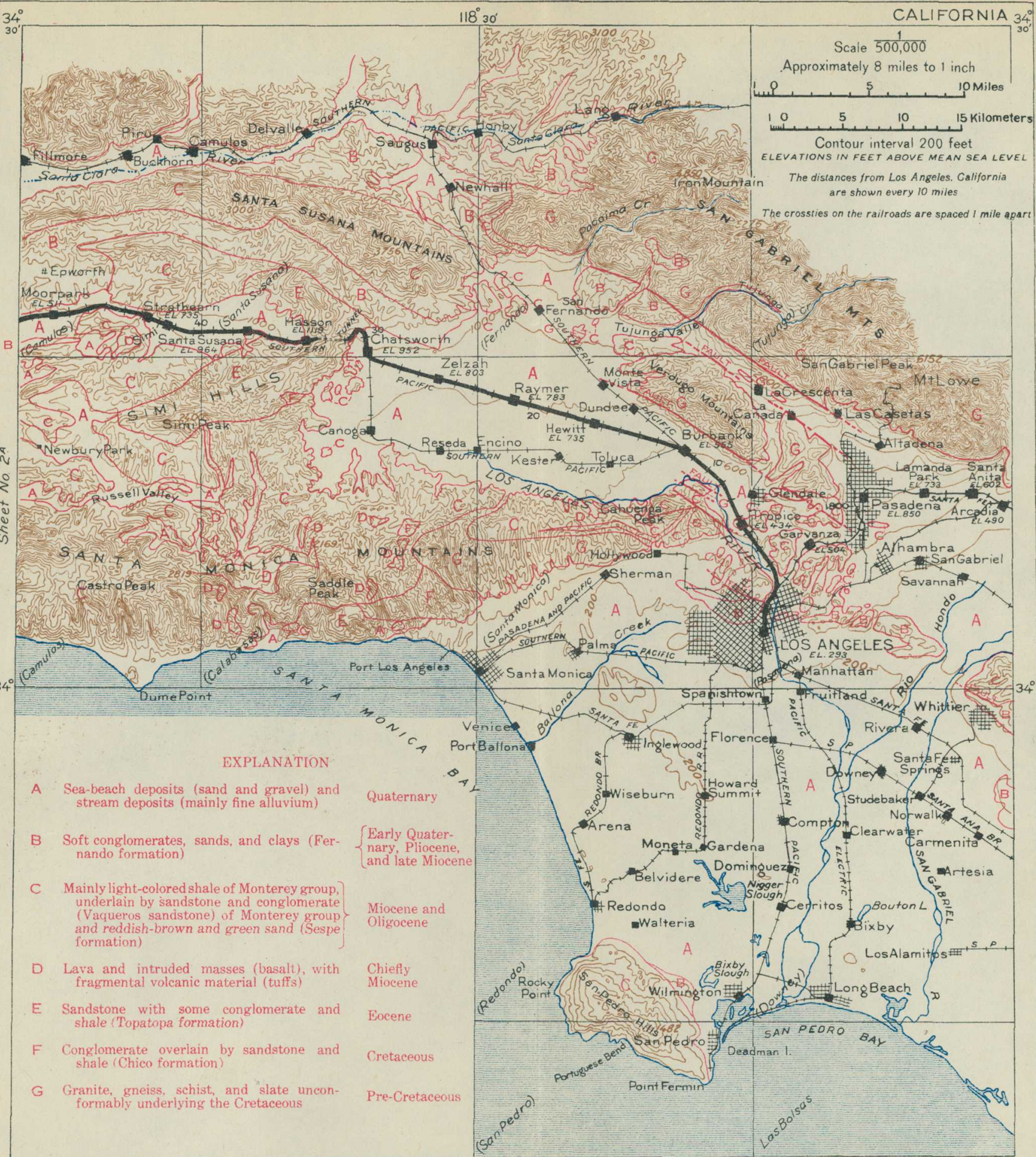




\section{GEOLOGIC AND TOPOGRAPHIC MAP}

\section{OF THE \\ COAST ROUTE}

\section{From Los Angeles, California, to San Francisco, California}

Base compiled from United States Geological Survey Atlas Sheets; from railroad alignments and profiles supplied by the Southern Pacific Company and from additional information collected with the assistance of this company

\section{UNITED STATES GEOLOGICAL SURVEY}

GEORGE OTIS SMITH, DIRECTOR

David White, Chief. Geologist

R. B. Marshall, Chief Geographer

\section{5}

Each quadrangle shown on the map with a name in parenthesis in the lower left corner is mapped in detail on the U. S. G. S. Topographic Sheet of that name. 
Ynez Range, along the south base of which the railroad runs from Ventura to Point Conception, a distance of nearly 75 miles. Its structure in general is anticlinal, the crest of the arch being pushed over (overturned) to the south. It consists principally of Topatopa (Eocene) and Sespe (Oligocene) rocks, flanked along the lower hills by sandstones and shales of the Vaqueros and later beds of the Monterey group (Miocene).

The prominent sharp ridge on the right, north of Somis (see sheet $2 \mathrm{~A}$, p. 110) in which light-colored and reddish formations are exposed,

\section{Somis.}

Elevation 254 feet. Los Angeles 55 miles. is the west end of Oak Ridge. It is composed largely of Monterey shale, which in places has been turned brick-red through the oxidation of its former oil content. The hills between Somis and Oak Ridge consist largely of the Fernando formation.

In Pleasant Valley in the neighborhood of Somis and Camarillo (ca-ma-reel'yo) there are 17,800 acres of beans now growing. Large Camarillo. quantities of honey, walnuts, and dried fruit are also produced here. On the left (east) a few miles from

Elevation 140 feet.

Los Angeles 58 miles.

Camarillo is the bold northwest end of the Santa

Monica Range. At its base can be seen a quarry of a gray igneous rock that is extensively used by the railroad for ballast. The terrace near Moorpark has a counterpart in the vicinity of Camarillo, due partly to stream action and partly to wave action.

The hills north of Pleasant Valley have been carved by erosion from a broad east-west anticline which lies south of the main Oak Ridge arch. The west end of this anticline disappears (plunges) under the alluvium of the Hueneme (way'nay-may) Plain. Its flanks are covered by the soft Fernando beds, which extend northward across Santa Clara Valley.

Under the Hueneme Plain is one of the best-developed artesian basins in southern California. The wells range in depth from about 50 to 200 feet and yield a good flow of excellent water that is utilized for irrigating beans and sugar beets, which are produced in enormous quantities.

Oxnard is surrounded for miles by fields of beans and beets and is one of the greatest sugar and bean centers in the

\section{Oxnard.}

Elevation 45 feet. Population 2,555. Los Angeles 67 miles. world. In the large factory seen to the left of the railroad as the train enters the town 3,000 tons of beets are sliced daily and 1,500 carloads of sugar are produced annually.

A sinking of the land less than 100 feet, a moderate depression in comparison with movements that are known from geologic evidence to have taken place along the California coast, would cover the whole Hueneme Plain with salt water. The plain is doubtless the old delta of Santa Clara River, which is crossed at milepost 404, near. Montalvo. 
From Montalvo a branch of the Southern Pacific runs up Santa Clara River to the oil district and connects with the San Joaquin Valley line of the same company. Immediately Montalvo.

Elevation 90 feet. Los Angeles 72 miles. northeast of Montalvo are the remnants of one of the old sea or river terraces, and half a mile farther northwest is another remnant. The hills north of Santa Clara River, between Montalvo and Ventura, consist of Fernando beds, from 8,000 to 10,000 feet in total thickness. Fossils found in different layers indicate that this formation ranges in age from the upper Miocene to Pleistocene. (See table on p. 94.) The beds are soft and form the south side or limb of a broad anticline whose axis crosses Ventura River in an east-west direction about $2 \frac{1}{2}$ miles north of the city of Ventura. Consequently the beds near Ventura dip south, whereas those north of the anticlinal axis dip north. Knowledge of such structural relations as are here outlined is very important in prospecting for oil. This great area of Fernando beds extends northeastward for about 20 miles as a belt of relatively low hills between Sulphur Mountain on the north and Santa Clara River on the south.

Sulphur Mountain is an anticlinal fold of Monterey shale. The fold is overturned toward the south, and the steepness of the south face of the mountain is due to this structure. This steep face is plainly visible in clear weather from the railroad between Santa Paula and Montalvo. Some of the best oil in the State comes from wells on the south face of Sulphur Mountain.

The city of Ventura (abridged from San Buenaventura) is pleasantly situated on the terraced slopes overlooking the sea between the mouths of Santa Clara and Ventura rivers. Besides

\section{Ventura.}

Elevation 4 foet. Population 2,945. Los Angeles 77 miles. being a delightful seaside resort it manufactures some machinery and has a large trade in beans, sugar beets, apricots, and other crops. With its many charming homes, wealth of flowers, and lawns of the Japanese clover (Lippia repens), Ventura invites more than the passing glimpse to be had from the train. Its mission, built in 1782, is still in use and may be seen, together with the county courthouse, from the train by looking up the streets on the right, soon after leaving the station.

A branch line runs from Ventura up Ventura River to Nordhoff, 16 miles away, in Ojai (o-high') Valley, inclosed by mountains of which Topatopa $(6,351$ feet) is chief. The wild Matilija (ma-teelee'ha) Canyon and Wheelers Hot Springs are near by. Nordhoff is noted as a winter resort. The route from Ventura thither crosses the Fernando, Monterey, and Sespe formations and the Sulphur Mountain fault.

On the west side of the mouth of Ventura River, about a mile northwest of Ventura, are some finely developed sea terraces. The train 
skirts one of these on the right, and the deep gullies expose the sand and gravel on its outer edge. Remnants of the same terraces, some of them extending up to an elevation of about 500 feet, may be noted at several points from Ventura northwestward for 15 or 20 miles to the vicinity of the mouth of Rincon (rin-cone') Creek. That these terraces mark the positions of old sea beaches is known to the geologist not only from their form but from other more convincing evidence. Along the beaches of the present day live clamlike mollusks (Pholas) which by turning round and round and using their shells as a sort of auger, bore for themselves holes in the rock in which they live. Holes unmistakably formed in this way can be found along the inner edges of some of the terraces that are now hundreds of feet above the ocean. Moreover, the gravels that lie on the terraces contain many species of marine shells.

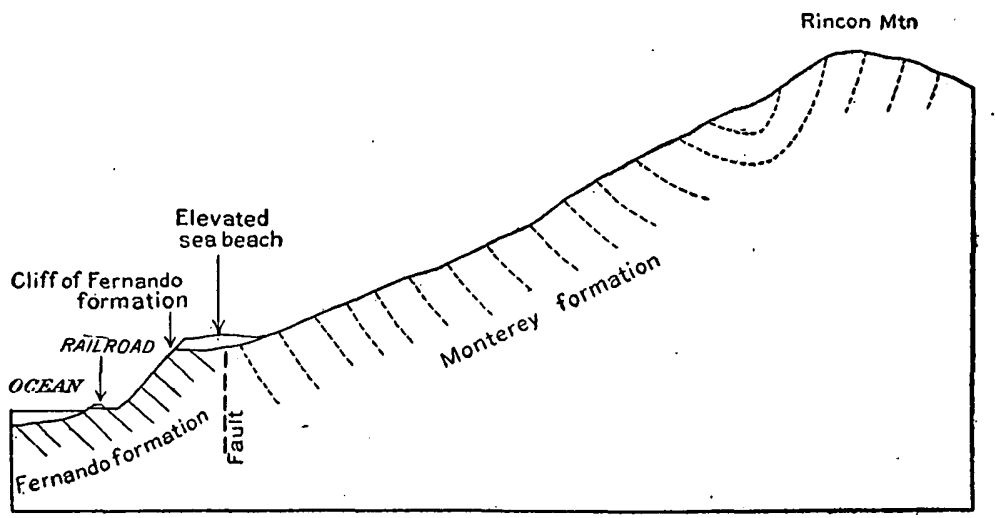

FIGURE 14.-Generalized cross section from the Pacific Ocean to Rincon Mountain, Cal., showing apparent relations of the formations.

For 2 or 3 miles west of Ventura the road lies on a low terrace about 40 feet above the waves. Just beyond milepost 394 , on the right, is a prominent hill that was formed suddenly about 40 years ago by a landslide that buried the stage road.

The hills along this part of the coast consist of coarse conglomerates and sandstones of the Fernando formation, dipping westward at an angle of about $45^{\circ}$. Toward the northwest the shore line cuts lower and lower into the formation, exposing soft sandstones and sandy shales.

Beyond Los Sauces Creek (sow'ses, Spanish for the willows), having crossed the anticline referred to on page 104, the traveler comes at milepost 388 to bold bluffs of the Fernando beds, which dip to the northeast and are overlain by the horizontal Pleistocene beds of an uplifted marine terrace. A generalized cross section from the shore to Rincon Mountain (fig. 14) illustrates the apparent relations of the formations in this region.

At a point 12 miles northwest of the mouth of Ventura River, near milepost 385, between Seacliff and Rincon Point (Benham), 
the shore line crosses the contact between the Fernando and the Monterey formations. Remnants of terraces are to be seen all along here at different heights above sea level. The layers of the Monterey shale, as a rule, are highly contorted and wide areas of intricately crumpled shale are laid bare at low tide. In general the beds dip to the south at fairly high angles. The canyons which cut into the shale are sharp and steep sided and afford excellent exposures of the rocks.

At several places dark-colored oil sands are interbedded with the shale. The saturation of these sands is so small and the structure is so unfavorable that no productive wells have yet been drilled between Punta Gorda and Carpinteria.

At Benham the railroad crosses Rincon Creek, which is here on Monterey shale, and traverses an alluvial plain for several miles.

Benham. An asphalt mine is plainly visible on the left side Los Angeles 91 miles. of the track. Large quantities of this black asphaltand the asphalt distilled from it in the old refinery near by. The underlying shale (Monterey), from which the oil oozed into the Pleistocene deposits and there evaporated in part to form the asphalt beds, is visible in the bottoms of the pits, and is also well exposed in several cuts along the track immediately south of the refinery. One deep well has been drilled in the Monterey beds half a mile east of the refinery, but no commercial deposits of oil were found.

Carpinteria (car-pin-tay-ree'ah, Spanish for carpenter shop) was named in August, 1769, by Friar Juan Crespe and his companion Carpinteria. pioneers, who found the Indians making dugouts. Elevation 5 feet. Los Angeles 93 miles.

Here is a wonderful grapevine, probably as old as the missions, whose trunk is 8 feet in circumference, larger than any other known on the continent. Its enormous yield of 15,000 to 20,000 pounds of grapes is unequaled, being several times more than the yield of the famous vine at Hampton Court, England.

On a sea terrace nearly 2 miles wide along the hills back of Carpinteria great quantities of fruit, nuts, and beans are raised. Beyond this alluvial terrace rises a sharp ridge composed of the Topatopa and Sespe formations, dipping at angles from $60^{\circ}$ to $75^{\circ}$ toward the coast. These beds are cut by a pronounced fault on the north side of the ridge. Still farther north, visible from the train, is the main Santa Barbara Range, which consists of a great anticline overturned to the south and exposing the beds of the Topatopa formation and the overlying Sespe. The beds on the south side of the range dip northward in consequence of this overturn. West of Carpinteria the terrace gradually narrows. A lagoon visible on the left indicates slight recent subsidence of the coast. 
The high ridge of Topatopa and Sespe rocks extends to Toro Canyon, northeast of Summerland. From this point it slopes off into the bills north of Summerland, which are composed of red sandstones and shales (Sespe), black shales and some interbedded sands (Vaqueros), and the overlying diatomaceous shales with two interbedded layers of volcanic ash of the Monterey group, all dipping toward the coast at high angles.

The people of Summerland, once a pleasure resort, are now successfully invading the adjacent ocean bed and Summerland.

Elevation 5 feet. Los Angeles 99 miles. pumping oil out of it (Pl. XXVI, p. 108). The sight of oil derricks on piers extending out into the ocean is unique. The wells range in depth from 300 feet near shore to 1,200 feet at the end of the longest wharf. ${ }^{1}$

At Summerland the Monterey group is overlain by the Fernando formation, both dipping toward the sea. A local anticline is developed in these Fernando beds, and on the flanks of this arch and in the area underlain by the seaward-dipping beds is located the Summerland oil field. The Fernando beds are overlain by coarse, nearly horizontal beds of Pleistocene age which underlie the soil over the. whole Summerland-Carpinteria terrace. These beds are impregnated with oil in the sea cliff in Summerland, and the productive beds of the Fernando are also oil-bearing where exposed along the same cliff. A conspicuous unconformity between the two formations is exposed near the north end of town.

Miramar (Spanish for behold the sea), a village remarkable for its wealth of flowers, is between Summerland and Santa Barbara.

Miramar.

The land here slopes gradually up from the ocean toward the foot of the range. This even slope is the
Los Angeles 100 miles. surface of an alluvial deposit brought down by streams from the mountains. Such deposits at the mouths of canyons are known as alluvial fans or alluvial cones.

The low hills seen to the right (northwest) on the way between Miramar and Santa Barbara are the remains of one or more old sea terraces that flank the range in the vicinity of Santa Barbara and have been partly eroded away. The south face of these hills consists of Monterey shale, dipping steeply toward the north and behind them toward the mountains, are successively the Vaqueros and

1 The Summerland oil field was opened in 1891 and was soon completely drilled. Only a few of the wells are now being operated, and these produce an average of about 2 barrels a day apiece. On Dec. 31, 1912, the Summerland district contained 152 producing wells, and the production for that year was 65,376 barrels. In 1894 the production was
1,500 barrels. The greatest annual production was 208,370 barrels, the quantity produced in 1899 , and the total production from 1894 to 1913 , inclusive, was 1,867,594 barrels. The oil is dark brown or black and ranges in gravity from $9^{\circ}$ to $18^{\circ}$ Baumé. 'It is used principally for the manufacture of asphalt, for fuel, or for road dressing. 
Sespe formations. The principal part of the range, as previously described, consists of steeply dipping beds of the Topatopa formation.

A local anticline extending in a southeasterly direction is developed in the hill about three-fourths of a mile west of Montecito. This affects the Fernando formation much like the anticline at Summerland, but although the Summerland fold yields oil the Montecito fold does not.

Near Santa Barbara the train passes a lagoon which, like that at Carpinteria, indicates a recent settling of the coast.

The city of Santa Barbara lies in a broad valley between the Santa Ynez (ee'ness) Range on the northeast and a group of low hills on the southwest. To the southeast this valley opens on Santa Barbara. the Santa Barbara Channel. The inclosing hills rise Elevation 6 feet. Population 11,659. Los Angeles 104 miles. in gently sloping sea terraces on which in great part the city has been built. Sheltered from the ocean winds by the hills to the west and looking out over the sparkling blue waters of the channel, Santa Barbara enjoys a situation and a climate that have made it famous as a resort and give its gardens such beauty as can be found in few other places in the world.

The old mission church, built in 1786, is one of the best preserved in California and has been pictured on hundreds of post cards and photographs. It is well worth visiting.

Lavigia Hill, directly southwest of the city, is composed chiefly of beds belonging to the Fernando formation, containing at a number of places well-preserved fossil sea shells of Pliocene age. At the east base of the hill, near the bathhouse, is an exposure of soft limy beds (marl) containing fossil marine shells and impressions of the mosslike sea animals known as bryozoans. These also are Pliocene. Along the coast west of Santa Barbara Point the Monterey shale is exposed underlying the Fernando beds of Lavigia Hill.

The hills lying at the foot of the main range just north of Santa Barbara and extending westward for several miles have been shaped by erosion from one or more old marine terraces which formerly stretched along the seaward base of the range.

The railroad, from a place near Santa Barbara to Point Conception, a distance of about 40 miles, follows a well-defined shore terrace but little above sea level. On and near this terrace are walnut groves, orchards, bean plantations, and broad areas of rolling oat and barley hay lands. From it may be had broad outlooks over the sea, with its floating masses of sea weed, now mapped by the Gowernment as a possible source of potash, and inland views of the rugged Santa Ynez Range, with its white rocks projecting from what at a distance looks like a mossy cover. of chaparral. This terrace is capped by soft conglomerates and sandstones which show in many railroad cuts their horizontal beds; wonderfully sculptured into vertical forms by the heavy rains of winter. (See Pl. XXVII.) These uplifted shore 


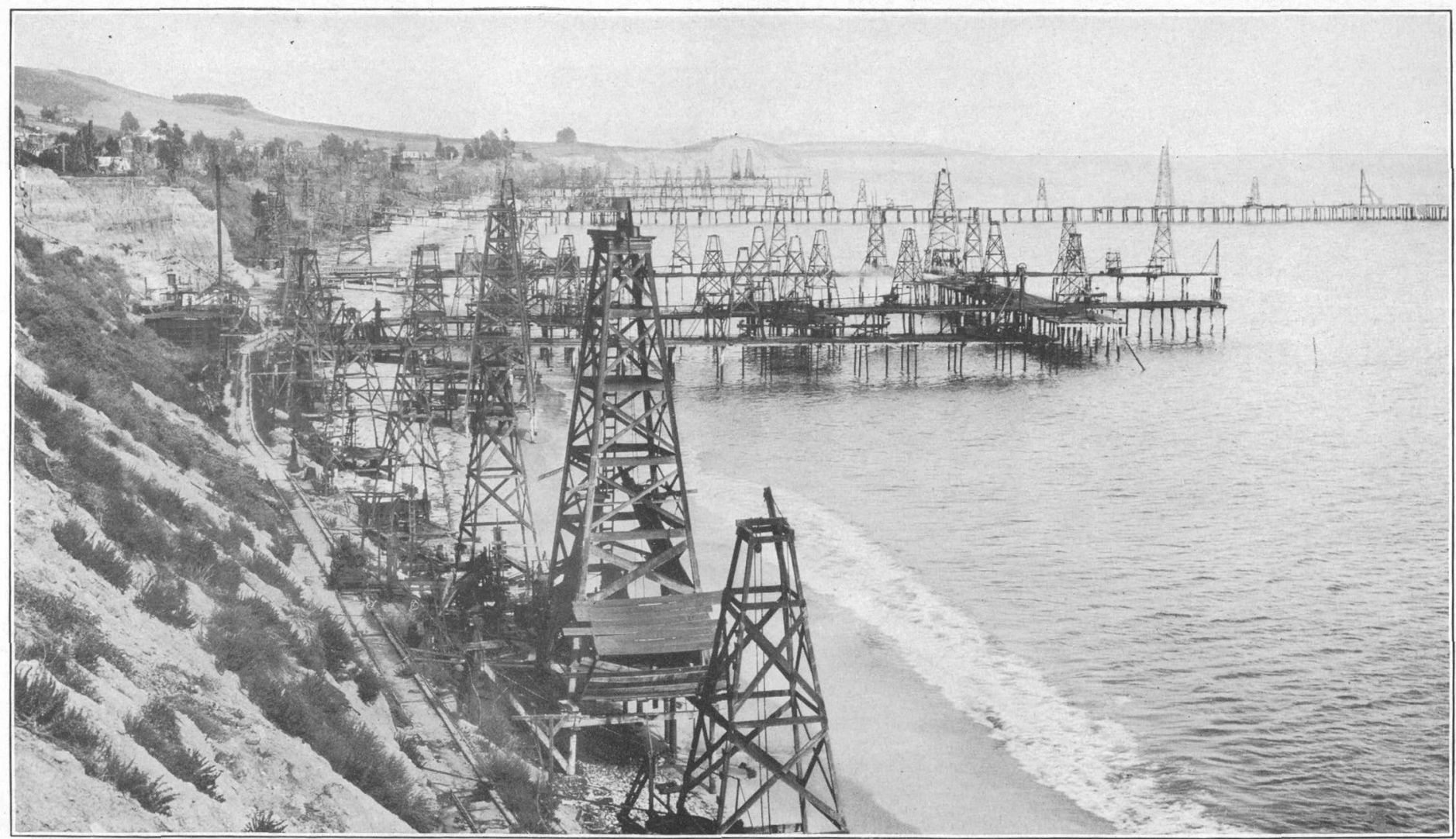

SUMMERLAND OIL FIELD, CAL. 


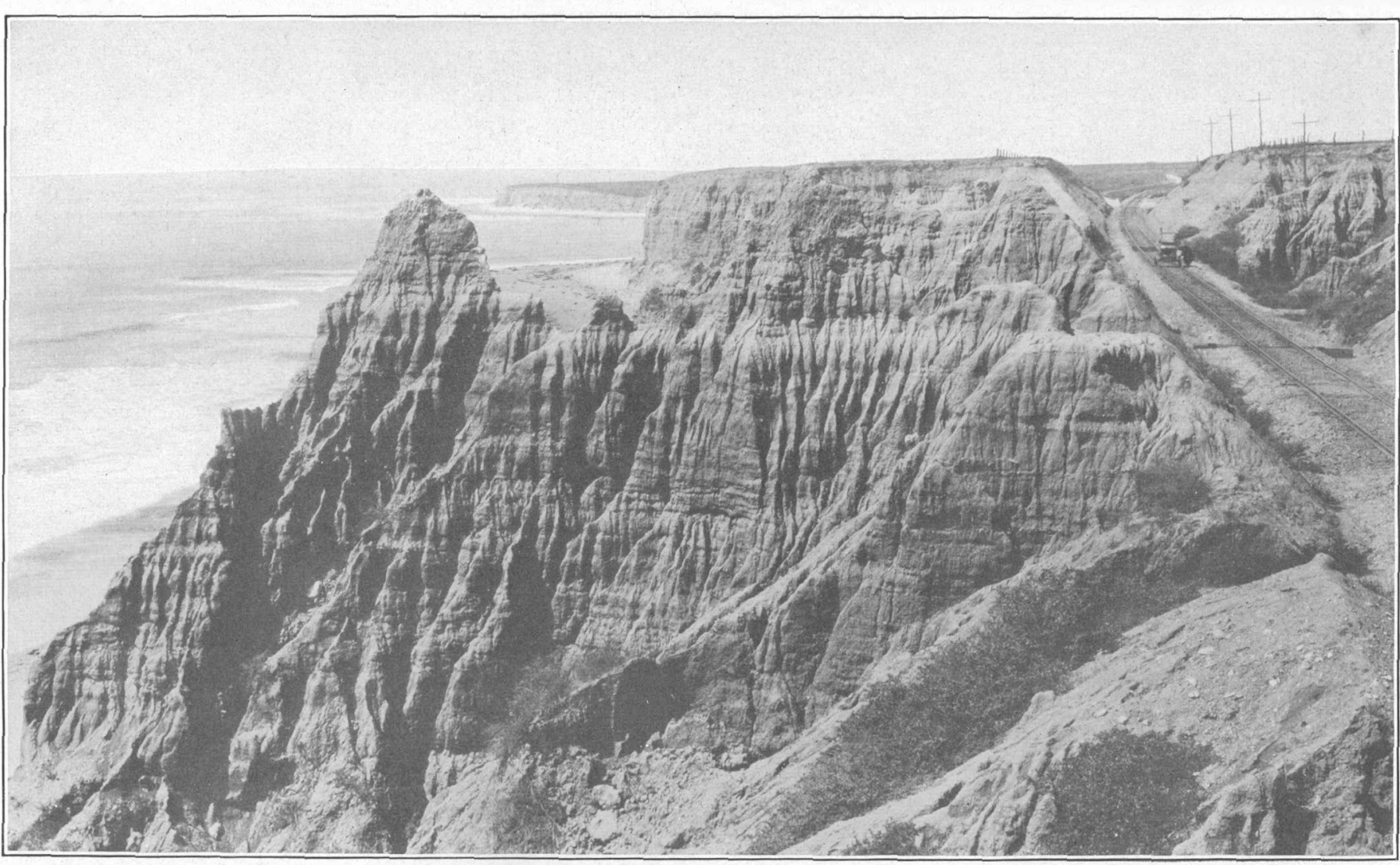


deposits, representing the combined action of sea waves and land streams, are well exposed about 6 miles north of Santa Barbara (at 365 miles from San Francisco), where they rest on upturned and contorted beds of Monterey shäle.

At Goleta (go-lay'ta, Spanish for schooner), amid walnut groves on the right, is a nursery of the Southern Pacific Co., in which are

Goleta.

grown trees, shrubs, and flowers to ornament the staElevation 38 feet.
Los Angeles 112 miles. Los Angeles 112 miles. of this treatment of sand will be seen beyond Point Arguello (ar-gwail'yo, Spanish for faintness), where the Santa Ynez Mountains end at the ocean. A large lagoon on the left, just west of Goleta, indicates coastal sinking.

On the right, north of Elwood, is a famous olive grove and oil factory. West of Elwood some of the larger streams from the mountains have gashed the terrace which the railroad is Elwood.

following, and some beautiful views of ravines and Elevation 84 feet.
Los Angeles 116 miles, Los Angeles 116 miles. practically true from Bell Canyon (milepost 358) west to Gaviota. The larger canyons cut back into the mountains, exposing the several southward-dipping formations in series. The light-colored rocks in the main range are Topatopa, the reddish rocks in front of them Sespe, and the shales along the lower hills, forming the foundation for the terrace, are Vaqueros and later beds of the Monterey group.

Naples and Capitan (see sheet 3A, p. 114) are small places beyond Elwood. From Orella (o-rail'ya), the next station, to Gaviota Orella.

the Monterey shale beds along the coast are very uniform, having a southerly dip of $30^{\circ}$ to $45^{\circ}$. They are well exposed along the foot of the sea cliff at low tide: The straight shore line along this part of the coast is due to the uniform trend or strike of the beds and their steep seaward inclination or dip, which render them very resistant to the attack of the waves. Nevertheless, at a number of places between Tajiguas (ta-hee'gwas), 346 miles from San Francisco, and Honda (ohn'da, Spanish for deep), 310 miles, the railroad company has been compelled to build a sea wall of concrete.

At several points the low terrace which the railroad follows is covered by bowlders from the hills immediately to the north. In the vicinity of Gaviota these hills come close to the shore, and a good view may be had of the coarse, steeply inclined sandstones.

Alcatraz.

AtAlcatraz (Spanish-American pronunciation al-catrahss', meaning pelican), on the right (north), there Los Angeles 134 miles. is an oil refinery to which oil is piped across the Santa Ynez Mountains from the Santa Maria field. 
From Gaviota nearly to Point Conception the rocks dip south, but at El Cojo (co'ho, Spanish for cripple), 11 miles beGaviota.

Elevation 92 feet. yond Gaviota, the shale beds dip north, indicating Los Angeles 135 miles. some complications of structure at the pronounced bend in the coast which forms Point Conception. The shale extends northwestward from Point Conception to Surf (Lompoc Junction).

The wind-swept country near Point Conception is devoted to the raising of cattle and hay. On the point are a lighthouse (Pl. XXVIII, p. 118) and a life-saving station. From the train Concepcion.

Elevation 106 feet.

Los Angeles 150 miles. in passing from Carpinteria to Concepcion, a distance of 56 miles, beautiful views are obtained of the Santa Barbara Islands. The intervening Santa Barbara Channel is shallow and, with the islands, belongs to the continent rather than the ocean. Beyond the islands the depth of water increases very rapidly, and this steep submarine slope, which on land would appear as a large cliff, marks the real boundary between continent and ocean. This slope has probably been formed by faulting as the continent rose. It runs north and south off Point Conception and determines the abrupt change in the trend of the coast.

At milepost 320 the train crosses Jalama (ha-lah'ma) Creek. On the left, near the creek, is the house of an early Spanish settler who harbored the 200 survivors of the Yankee Blade, wrecked on this coast in 1856. The anchor of the Yankee Blade may be seen on the left (at milepost 318), in the field, just after the train emerges from a small tunnel a mile southeast of Sudden.

Very good exposures of Monterey shale are to be

Sudden.

Elevation 75 feet.

Los Angeles 158 miles. seen near Sudden, where cracks in the siliceous shales are filled with hardened asphaltum.

The lighthouse at Point Arguello is built on contorted Monterey shale, here very well exposed. The terrace which the railroad follows is narrow but well defined, and slopes gently toward the foot of the hills. At some points in the region between Sudden and Point Arguello there are indications of an older, higher terrace. Near Point Pedernales (pay-dair-nah'lace, Spanish for flints) the railroad crosses Canada Honda (ca-nyah'da ohn'da) Creek, near the mouth of which, within plain view, is the wreck of the Santa Rosa, blown ashore in 1911.

From Point Pedernales, which marks the western extremity of the Santa Ynez Mountains, northward the country near the coast is covered with sand dunes which have drifted from the beach over the terraces and lower hill slopes, impelled by the strong winds which continually prevail in this region. The drifting sand sometimes 


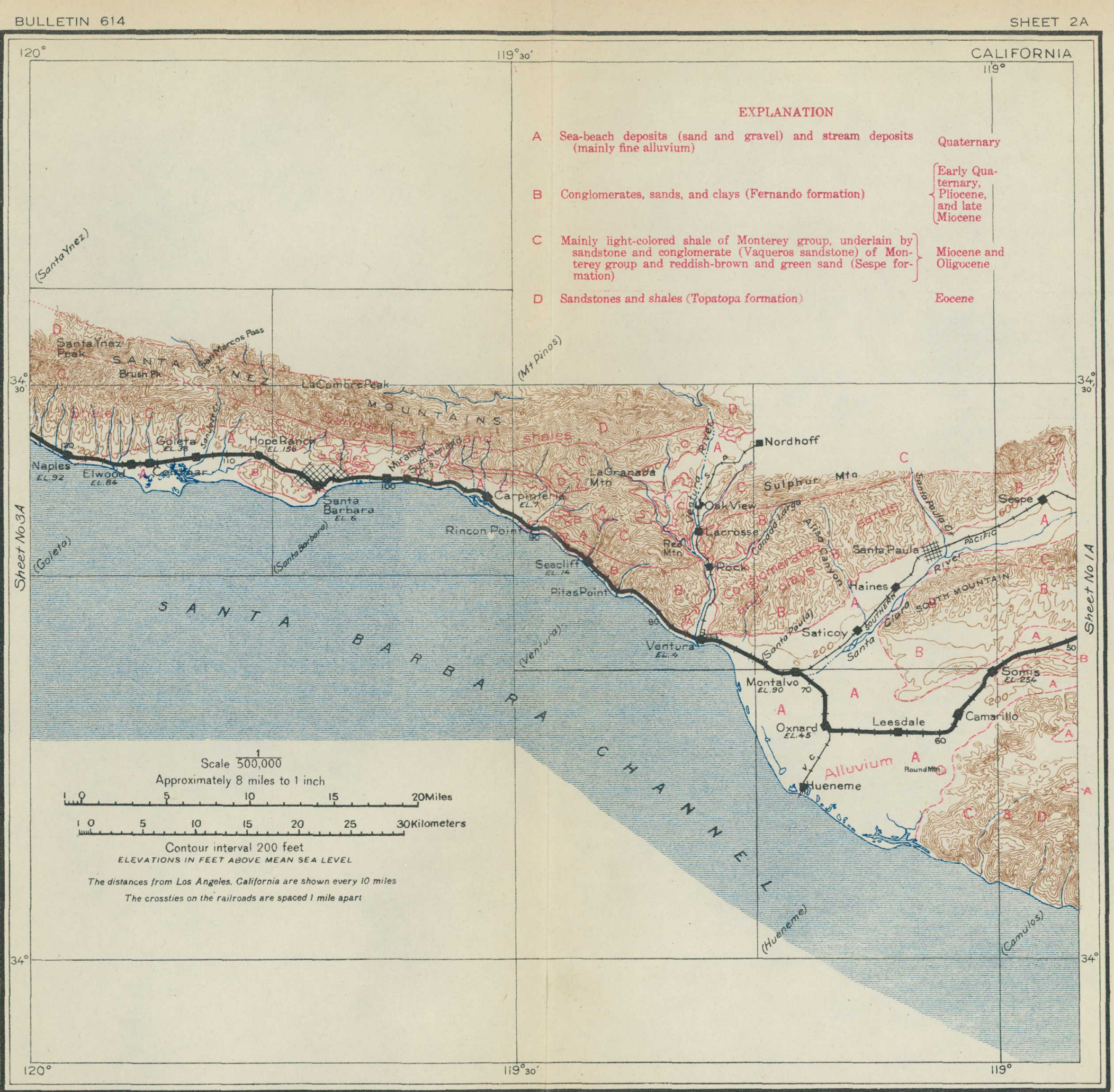


covers the railroad track and delays traffic. To prevent this the Southern Pacific Co. is planting successfully acacia trees (Acacia latifolia) and a coarse, stout beach grass (Ammophila arenaria) that is used on the dikes in Holland.

About 5 miles southeast of Point Pedernales is a mountain called El Tranquillon (tran-keel-yohn', Spanish for maslin, a mixture of wheat and rye). The reason for the application of this name to the mountain is unknown. Two or three areas of Franciscan (Jurassic?) rocks are exposed just north of El Tranquillon, indicating that this formation is the core of the main Santa Ynez uplift.

The hills northeast of Point Pedernales to an elevation of over 1,000 feet are covered by old terrace and sand-dune deposits.

Surf (Lompoc Junction), at the mouth of Santa Ynez River, is well named from the breakers that tumble on its broad beach-Lompoc Beach. Here the Monterey shale appears again, Lompoc Junction. dipping to the south at a rather low angle. Lom-

Elevation 47 feet. Los Angeles 172 miles. poc Beach is a "gold beach" that renews its riches every few years, and occasionally it is the scene of beach placer mining. The strong waves due to the winter storms strike the Lompoc Beach between Honda and Purisima Point at a low angle and cause the sand to drift northward. The sand made up of lighter minerals drifts most rapidly, and thus leaves behind along this beach the black sand of dark, heavy minerals. The black sand contains some gold, and when the sand is long exposed to the concentrating wave action it may become rich enough to pay for washing, but the gold content is not large, the beach placers here being not so rich as those of the coast of northern California and southern Oregon.

From Lompoc Junction a branch railroad ascends the Santa Ynez Valley for 10 miles to the town of Lompoc. The climate and soil in this vicinity are particularly adapted to seed growing, and great quantities of beans and sweet peas are raised herefor seed. Much of the mustard produced in the United States comes from Lompoc. The largest industry of the place, however, is the mining and milling of diatomaceous earth, of which there are large deposits in Miocene shale (Monterey) a few miles to the south. Thousands of tol. of white limestone are also shipped from Lompoc annually.

Northeast of Lompoc Junction is Burton Mesa, part of an $u^{\prime} \cdot{ }^{\prime}$ ially broad and even marine terrace. For about 12 miles north of $\mathrm{L}$ noc Junction to Schumann Canyon the railroad passes through a re " " of sand dunes. These rest on a terrace cut in Monterey shale, whic: just south of Tangair is hard, white, and porcelaneous. At many places the hard layers of the shale are full of minute cracks which contain hardened asphaltum. At other places oil seeps from the shale. 
About 10 miles east-northeast of Lompoc Junction is the Lompoc or Purisima oil field, the wells of which are from 2,000 to 4,000 feet in depth and produce from 25 to 400 or 500 barrels each daily. ${ }^{1}$

Near milepost 298, just south of Tangair, there is a cut affording fine exposures of the siliceous Monterey shale. Here Tangair. the railroad attains the summit of Burton Mesa, Elevation 210 feet. whose surface has been cut by wave action across the Los Angeles 178 miles. tilted Monterey beds. There is an extended view over it on the right.

1 The Santa Maria oil district lies in northern Santa Barbara County, in the region of rolling hills between the Santa Ynez and San Rafael mountains. The district comprises three principal fieldsthe Santa Maria or Orcutt field, the Lompoc field, and the Cat Canyon field. Up to the present time the greater part of the development has taken place in the Orcutt field, as this was the first one discovered and exploited. The first successful well was finished in August, 1901. The wells in this field yield from 60 to 2,500 barrels of oil a day each, although initial yields of 2,000 to 12,000 barrels have been recorded. The gravity of the oil is from $18^{\circ}$ to $31^{\circ}$ Baumé. The wells of the Lompoc field yield oil of $16^{\circ}$ to $37^{\circ}$ Baumé. Successful wells were drilled in this field in 1904, and since that time the further development of this part of the district has been assured. In the Cat Canyon field the wells so far brought in have yielded from 150 to as high as 10,000 barrels a day. The oil in this field runs from $11^{\circ}$ to $19^{\circ}$ Baumé.

The Pacific Coast Railway connects the different fields with Santa Maria, Port Harford, and San Luis Obispo, the last named on the Southern Pacific Coast Line. The greater quantity of the oil produced is piped to the refineries at Gaviota and Avila, on the coast; the Associated Oil Co. owns the former and the Union Oil Co. the latter plant. The Standard Oil Co., which controls a small part of the output, has a pipe line connecting the district with Port San Luis.

The shales of the Monterey group are the probable source of the oil in the district and the present reservoir in some of the fields and are characterized by their diatomaceous composition.
The Fernando formation, a series of sandstone, conglomerate, and shale, rests unconformably upon the Monterey and derives its chief importance in connection with studies of this oil district from the facts that it obscures the oil-bearing formation over a wide area, that it affords through its structure a clue to the structure of the underlying Monterey, and that it acts as a reservoir for the oil in the Cat Canyon field and as a receptacle for escaping bituminous material in several localities within the district.

This district is a region of long sinuous folds, a peculiar type of structure characteristic of the Santa Maria region. It is near the axis of these folds that the productive wells are located.

In 1913 there were 289 producing wells and the output was $4,938,185$ barrels. The annual output of the district varied from 99,288 barrels in 1902 to $8,651,172$ barrels in 1907. The total output of the Santa Maria district from 1902 to 1913 , inclusive, was $56,599,642$ barrels.

This district yields four distinct grades of petroleum in addition to the heavy oil which flows from springs or collects as asphalt deposits. These petroleums vary widely in physical and chemical properties and as a consequence are utilized in many different ways, the lighter oils usually for refining and the heavier for fuels, road dressing, etc. The oil as it comes from the wells contains varying quantities of gas, often amounting to a considerable percentage. Some of this gas is very rich in gasoline hydrocarbons, which are removed before utilizing for fuel. The greater portion of the oil is refined at Port Harford and Gaviota, from which it is distributed by means of tank steamers. 
Beyond Schumann Canyon and Casmalia the formation exposed is the Monterey shale, which is much folded. About Casmalia.

Elevation 281 feet. Los Angeles 187 miles.

Casmalia considerable barley is grown for hay and grain. The rounded hills in this vicinity are golden in August with the bright little flowers of the tarweed.

North of Casmalia the railroad crosses a well-defined anticline. Several oil wells seen on the left (west) side of the track have been drilled on the south flank of this fold and obtained commercial quantities of very heavy oil at depths ranging from 1,800 to 2,500 feet.

At Schumann station, which lies on the north flank of the anticline, the Monterey shale is soft and thoroughly impregnated with oil, which colors it dark and trickles from it in places. Schumann. This is as good an exposure of the soft upper beds of Elevation 401 feet. the Monterey as can be seen along the railload. The Los Angeles 190 miles. lower portion of this shale formation is hard, thin bedded, and siliceous, but the upper portion is softer and does not show the bedding as plainly.

Beyond Schumann the railroad swings to the left, and the broad valley of Santa Maria River may be seen on the right. The train passes along the northeastern base of the Casmalia Hills, where the rocks exposed in most of the cuts are of Pleistocene age, although the Fernando formation occurs in the hills a short distance south of the track. Several old asphalt mines may be noticed in this vicinity. The asphalt occurs in the form of dikes and irregular lenses in the soft Fernando sandstones.

On the right (east) side of the track, about 2 miles south of Guadalupe (gwa-da-loo'pay), is Guadalupe Lake, the water of which has been impounded by drifting sands. Beyond the lake, at Betteravia, $\sim$ is a beet-sugar factory.

The rich alluvial valley about Guadalupe produces large crops of beans, beets, potatoes, and barley. The main Santa Maria Valley, which extends eastward from Guadalupe for 10 or 12 Guadalupe. miles, is primarily a structural valley that has been Elevation 79 feot. deeply filled with Pleistocene and alluvial deposits. Population 480**
Los $A$ ngeles 198 miles. A clearly defined terrace follows the north bank of Santa Maria River, and northeast of the valley are the San Rafael Mountains. The lower slopes are marked by an anticlinal fold, in the heart of which is a large mass of serpentine and Franciscan rocks. The flanks of this fold, including the larger part of the southwestern slope of the mountains, consist of distorted Monterey shale.

Just north of the Guadalupe station the railroad crosses Santa Maria River, the boundary line between Santa Barbara and San Luis Obispo counties. Looking southeast from this bridge the traveler can see Graciosa Ridge, with the wells of the Orcutt or old Santa $96286^{\circ}-$ Bull. $614-15-8$ 
Maria oil field in view on its flanks. Mount Solomon, a flat-topped, buttelike peak, composed of Tertiary rocks, is visible just to the left (east) of the oil field. It is the culminating point of Graciosa Ridge. Southwest of the Santa Maria bridge the drifting sands encroach to an elevation of 1,000 feet on the flanks of Sulphur Ridge. This encroaching sand rising so high on the mountains is one of the peculiar characteristics of this part of the coast.

For 14 miles north of Guadalupe the train passes through a region of wind-blown sand. On the left (west) as far as Bromela (bro-may'la) is a prominent ridge of sand dunes advancing upon rich farms. Farther north, between Bromela and Callender, the dunes have advanced far inland across the railroad, and the company has an expensive task in maintaining the roadway open. Between Callender and Oceano (o-say'ah-no) the advance is less rapid and lagoons have formed behind the sand. Just beyond Oceano, at the mouth of Los Berros Creek (Spanish for water cresses), Pismo Creek barely breaks through the barrier beach it has followed for 2 miles from Pismo.

On the way up Pismo Creek beyond Pismo (see sheet 4A, p. 120) the first rocks to be seen on the east are those of the Pismo.

Elevation 25 feet. Los Angeles 212 miles. Santa Margarita formation (Miocene), the equivalent of the lower part of the Fernando formation farther south. South of Edna the creek crosses a large area of these rocks, which in places are heavily charged with asphalt.

At the crossing of the Pacific Coast Railway just south of Edna are bold bluff exposures of asphalt-impregnated sandstones of the

\section{Edna.}

Elevation 224 feet. Los Angeles 217 miles. Pismo formation, which is probably of the same age as the Santa Margarita formation. They dip south at moderately low angles and are underlain by more steeply dipping shale beds of the Monterey group. These sandstones were formerly mined for asphalt, but the production of asphalt as a by-product from the refining of oil has for the present rendered them of no value.

Some oil wells have been drilled on the west side of the track south of Edna. One or two of these wells encountered oil in commercial quantities, but they have never been operated continuously, owing to mechanical difficulties caused by the thickness of the oil. The dark-colored asphaltic rock is cavernous in places and is eroded into grotesque forms. East of Edna are some well-developed stream terraces.

At Edna the railroad enters San Luis Valley, which extends northwestward for 20 miles. On the northeast the valley is bounded by the Santa Lucia Range and on the southwest by the San Luis Range. At the northwest end it opens to the ocean. This valley, unlike most valleys in the Coast Ranges, has no stream flowing lengthwise through it. Pismo and San. Luis creeks, which drain 


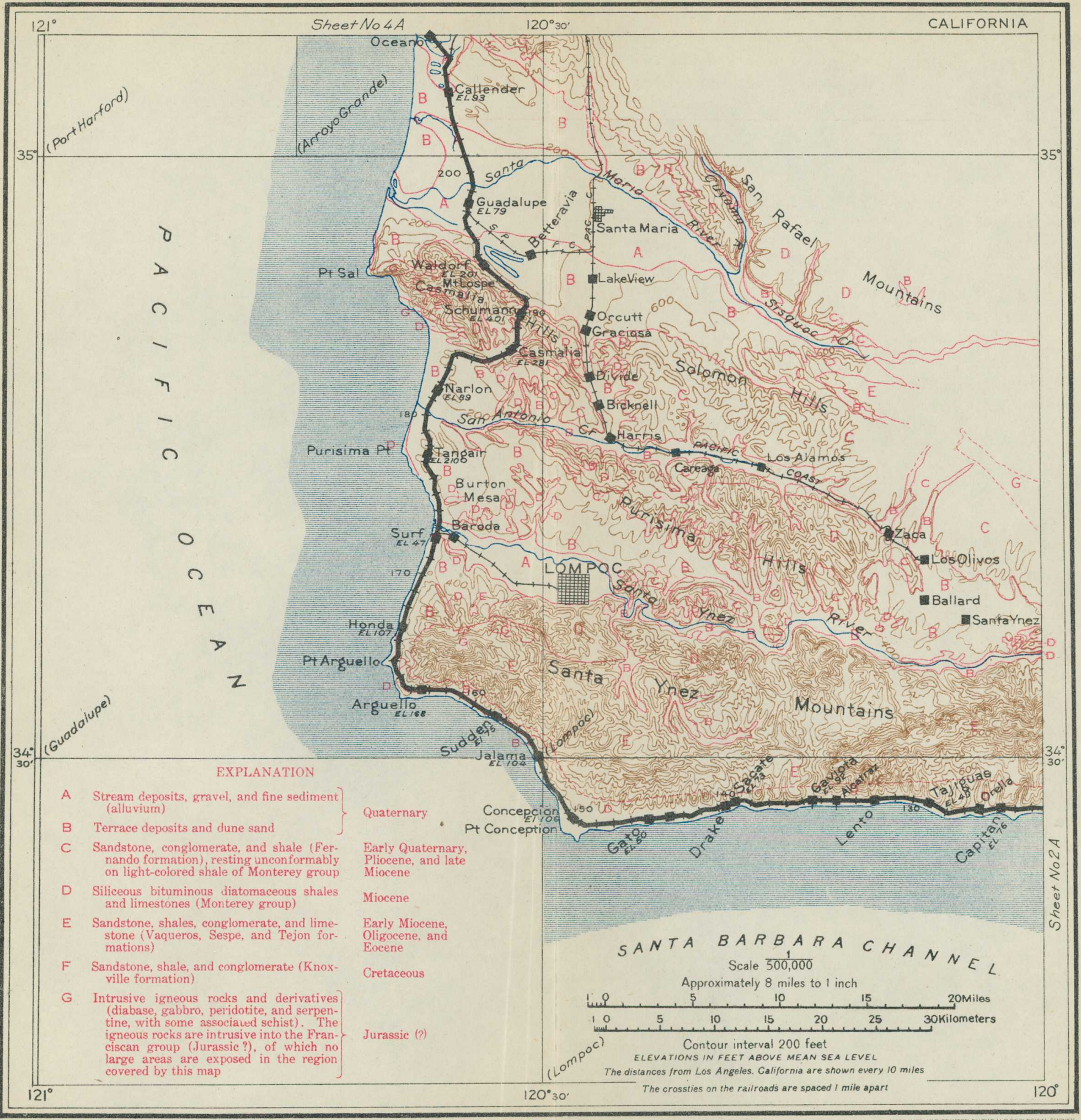




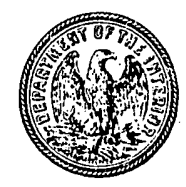

\section{GEOLOGIC AND TOPOGRAPHIC MAP} OF THE

\section{COAST ROUTE}

From Los Angeles, California, to San Francisco, California

Base compiled from United States Geological Survey Atlas Sheets; from railroad. alignments and profiles supplied by the Southern Pacific Company ard from additional information collected with the assistance of this company

\section{UNITED STATES GEOLOGICAL SURVEY}

\section{GEORGE OTIS SMITH, DIRECTOR}

David White, Chief Geologist

R. B. Marshall, Chief Geographer

\section{5}

Each quadrangle shown on the map with a name in paremthesis in the lower left corner is mapped in detail on the U. S. G. S. Topographic Sheet of that name. 
most of it, enter from the east and cut through the San Luis Range to the sea.

Edna is built in part on the Paso Robles (ro'blace) formation, of Pleistocene, Pliocene, and late Miocene age. The rocks composing this formation, however, are much better exposed farther north.

From a point 2 miles north of Edna to a point 1 mile beyond the town of. San Luis Obispo a set of rocks not hitherto seen on this route, the Franciscan group, is almost continuously exposed. ${ }^{1}$

The most prominent topographic feature in the vicinity of San Luis Obispo (Spanish for St. Louis the bishop) is the row of conical hills that begins with Islay (ees-lie') Hill, on the right (east), San Luis Obispo. a little over 2 miles southeast of San Luis Obispo, and - Elevation 237 feet. extending to Cerro Romauldo (ro-mowl'do), about 4
Population 5,157. Los Angeles 223 miles. miles northwest of the town. There are eight of these hills (Spanish cerros), the four larger northwest and the four smaller southeast of the city. These hills, of which The Bishop (1,502 feet) is the highest, are composed of igneous rock and are the cores of small volcanoes which broke through the Franciscan sedimentary rocks. The eastern part of Islay Hill consists of a surface flow of basaltic lavia.

From San Luis Obispo, which is a division point on the railroad, the Pacific Coast Railway runs to Port Harford on the coast, passing through the resort of Sycamore Warm Sulphur Springs. At Port Harford is the end of the Producers' Transportation Co.'s pipe line from the San Joaquin Valley oil fields.

San Luis Obispo is one of the old Spanish towns of California. A mission was founded here in 1772 by Father Junipero Serra, and the church building is still standing.

The most important metallic mineral resource in the San Luis region is chromite, which occurs in the serpentine of the San Luis and Santa Lucia ranges.

\footnotetext{
1 The rocks of the Franciscan group are older than the oil-bearing rocks over which the route has thus far lain and are probably of Jurassic age. They comprise sandstones, conglomerates, shale, and local masses of varicolored thin-bedded flinty rocks. The flinty rocks consist largely of the siliceous skeletons of minute marine animals, low in the scale of life, known as Radiolaria, and on this account they are called radiolarian cherts. All the rocks mentioned have been intruded here and there by dark igneous rocks (diabase, peridotite, etc.), which have in large part undergone a chemical and mineralogic change into the rock known

as serpentine. Closely associated with most of the serpentine are masses of crystalline laminated rock consisting largely of the beautiful blue mineral glaucophane and for that reason called glaucophane schist. Schist of this character is known in comparatively few parts of the world, but is very characteristic of the Franciscan group. It has been formed from other rocks through contact metamorphism-that is, through the thermal and chemical action set up by adjacent freshly intruded igneous rocks. The Franciscan group is one of the most widespread and interesting assemblages of rocks in the Coast Range.
} 
On leaving San Luis Obispo the train crosses San Luis Obispo Creek, which emerges from a canyon in the Santa Lucia Range, on the right (east). On the left is Cerro San Luis Obispo, one of the old volcanic necks. A mile and a half beyond the station, on the right, is the California Polytechnic School and in the foreground a ledge of rocks characteristic of the Franciscan.

The railroad curve known as "the horseshoe" begins at Goldtree, 4 miles from San Luis Obispo, with a grade of 2.2 per cent. The ascent continues through shallow cuts in sandstone belonging to the Franciscan group, but at the end of the horseshoe, above Goldtree, the road swings to the left and crosses a belt of serpentine to the open hilly country of the overlying Monterey shale. Near Serrano (elevation 941 feet) Franciscan rocks again appear in complex association with serpentine and dark intrusive rocks.- The railroad continues on these rocks principally for 4 miles, passing by six tunnels through ridges of diabase. The longest tunnel, 3,616 feet long, is farthest north and pierces the divide into Salinas Valley, nearly 600 feet beneath the summit.

The black earthy shales seen between the northernmost tunnel and Cuesta (239 miles from San Francisco) are of Lower Cretaceous (Knoxville) age. A little of the same shale was crossed between the first and second tunnels. The shale overlies the Franciscan rocks, but the two formations were not deposited continuously. The Franciscan rocks were raised above the sea and eroded, then submerged again and covered by the muds now consolidated as the Knoxville shale. The geologist expresses these facts briefly by saying that the Knoxville lies unconformably on the Franciscan. On the right (east) at Cuesta is an area of dark intrusive rock (olivine diabase). Beyond this the railroad passes across a small area of light-colored shale (Monterey), traverses another area of dark Knoxville shale, and enters upon a belt of sandstone, which with some conglomerate and shale composes the characteristic Chico (Upper Cretaceous) formation. The sandstones of the Chico weather into large blocks. Near Santa Margarita the sandstone is covered by recent alluvium.

The general trend or strike of the formations here, as elsewhere in this part of California, is northwest, in accord with the general alignment of ridges and valleys.

Santa Margarita is on the southwest side of a northwest-southeast depression which is followed for most of its length by Salinas (sa-lee'nas) River. The valley extends for 8 or Santa Margarita. 9 miles southeast of the town and is followed by Elevation 995 feet. Population 918. Los Angeles 239 miles. the railroad for about 10 miles to the northwest. It owes its form partly to geologic structure and partly to erosion; as it is occupied by comparatively soft Tertiary formations, while the hills on both sides are composed mainly of harder, older rocks. Along the southwest side of the 
valley, to the left of the railroad, are Franciscan and Cretaceous beds. On the northeast, to the right, is a large area of granite, probably of pre-Jurassic age. The valley represents a long, narrow trough or syncline along which the Tertiary beds have been bent down into the older rocks. Faulting along the sides took part in the formation of the syncline. Erosion afterward removed the Tertiary beds on each side of the down-folded and down-faulted strip, exposing the older rocks of the present hills. The Tertiary rocks of the present valley were protected to some extent by being inlaid, as it were, into the older rocks, but, being soft, they were hollowed out into a valley. At some stage in the erosion and hollowing process Salinas River several miles above Santa Margarita became deflected to the granite on the northeast side of the valley. Gradually the valley as a whole became deeper and wider, but the river had deepened the channel that it had begun in the granite and was unable to leave it. Consequently the river to this day leaves the belt of soft Tertiary rocks, turns northeastward into the hard granite and after flowing for 5 or 6 miles through that rock, returns to the main valley northwest of Santa Margarita. This is a case of what geologists call "superimposed drainage."

The Santa Margarita region is one of rolling hills well covered with the wild oat (Avena fatua $)^{1}$ and dotted with oaks. It is an excellent stock country. Growing on the bottom land of the adjacent valley are some of the finest white oaks (Quercus lobata) to be seen in California.

Half a mile beyond Santa Margarita, on the right at milepost 235, is the Producers 'Transportation Co.'s pump and ten oil tanks with an aggregate capacity of 75,000 barrels.

The type section and locality of the Santa Margarita formation is just north of the town, where the soft, more or less limy coarse sandstone of the formation occurs along the railroad for nearly a mile. These beds carry large fossil oyster shells which are characteristic of the Santa Margarita formation throughout the Salinas Valley region.

Near Eaglet, on the left (west), there are several abrupt changes from Monterey shales to the coarse beds of the Santa Margarita and vice versa. The hills on the right (east), across the Eaglet. river, are composed of granite. A bed of Vaqueros Elevation 885 feet. (va-kay'ros) sandstone that can be seen lapping up Los Angeles 244 miles. ably once arched completely over the granite, but part of it has been removed by erosion. The sandstone in turn is overlain by the Monterey shale.

${ }^{1}$,The wild oat, one of the most abundant and characteristic grasses of California, was brought to this country from Europe. 
The low hills on the east side of the river opposite Atascadero (a-tas-ca-day'ro, Spanish for a deep miry place) are composed of the Paso Robles formation, already seen at Edna. Atascadero.

Elevation 849 feet. The formation in general consists of gravels whose Elevation 849 reet.
Los Angeles 247 miles. It ranges in age from late Miocene to Pleistocene. Just north of Atascadero station, on the west side of the track, is a good exposure of the white fossiliferous Santa Margarita sandstone, dipping north and overlain unconformably by the light-colored Paso Robles gravel.

At Templeton the railroad turns northward, leaving the valley of the upper Salinas and passing through Paso Robles Canyon toward

Templeton.

Elevation 771 feet.

Los Angeles 253 miles. the lower or main Salinas Valley. Well-developed river terraces are to be seen in this vicinity.

Just before reaching Paso Robles station the train passes a gravel pit in which a tooth of an extinct elephant has been found. The gravel is of stream origin.

Paso Robles (Paso de los Robles, Spanish for pass of the oaks), with its hot sulphur springs and mud baths, is widely known as a pleasure and health resort. The springs have a

\section{Paso Robles.}

Elevation 720 feet. Population 1,441. Los Angeles 259 miles. temperature of $95^{\circ}$ to $110^{\circ} \mathrm{F}$. and the mud baths of $140^{\circ} \mathrm{F}$. The Camino Real (ca-mee'no ray-ahl', Spanish for king's highway), at first a trail but later a road connecting the missions from Mexico to San Francisco, passes near by. and is now used by automobile tourists. The nearer hills on both sides of the railroad from Paso Robles to San Miguel are composed entirely of the Paso Robles formation.

At milepost 214, 2 miles north of Paso Robles, near the railroad and the river, is the new hot mud bathhouse of the Paso Robles Hotel. The Camino Real is on the left, and beyond it are attractive parklike fields and hills with scattered oaks.

On the left as the train enters the little village of San Miguel (me-gale') is the old mission, built in 1797, of adobe brick, with its bell in front and remnants of the inclosing walls on

\section{San Miguel.}

Elevation 615 feet. Population 830.*

Los Angeles 268 miles. the right. . San Miguel is near the head of the main Salinas Valley, which extends northwestward in an almost straight line for nearly 100 miles to Monterey Bay. It is one of the best examples of the narrow northwest-southeast valleys, owing their form to erosion controlled by geologic structure, that are characteristic of the Coast Range between San Francisco and Los Angeles. From the vicinity of San Miguel the northeast slope of Salinas Valley, toward the Gabilan (ga-vee-lahn') Range, is suggestive of a great plain gently tilted toward the observer and furrowed by streams flowing straight down the slope. It is perhaps a tilted block of the earth's 


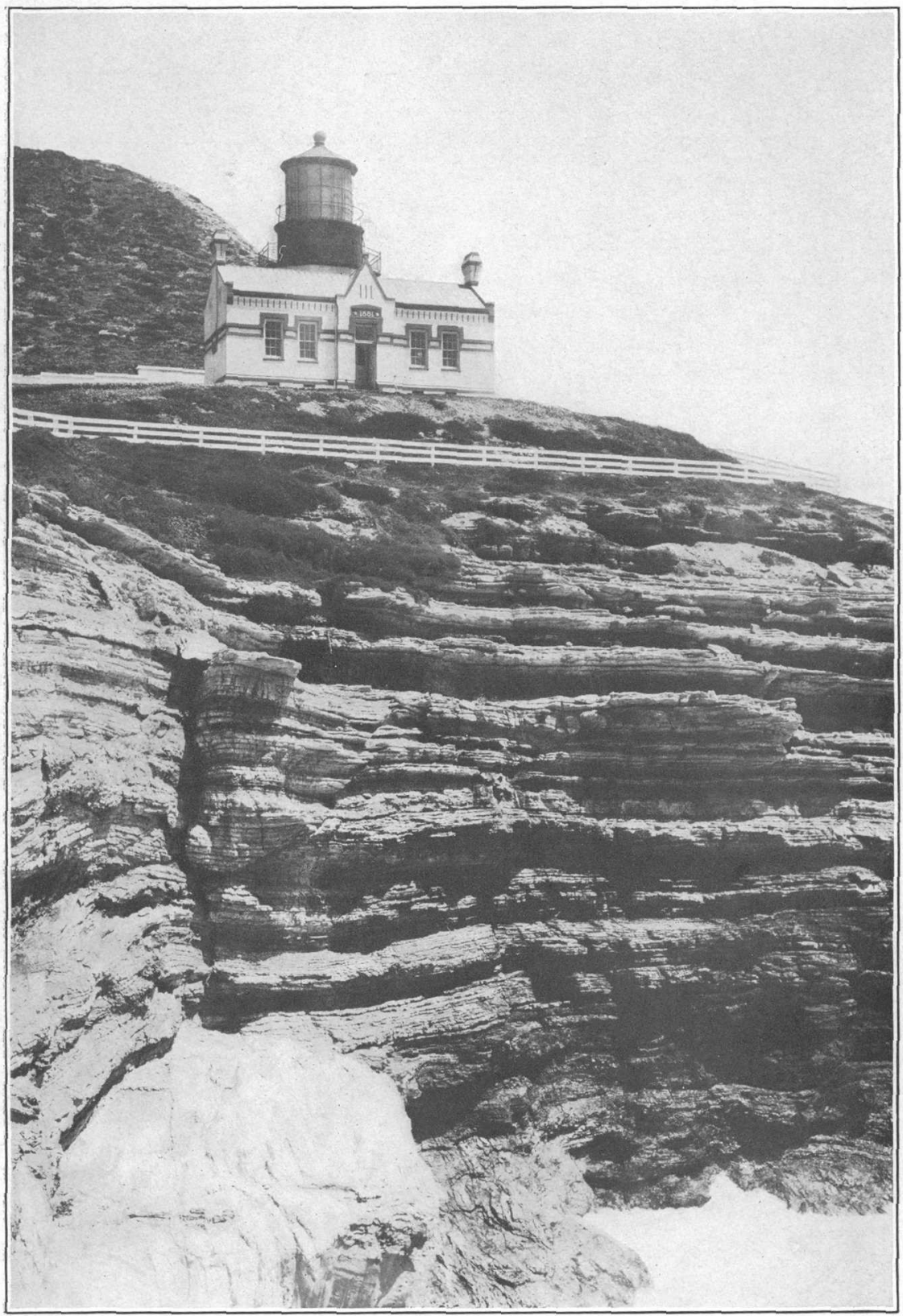

LIGHTHOUSE AT POINT CONCEPTION, CAL.

Built on cliff of remarkably uniform thin-bedded Miocene shale (Monterey). 


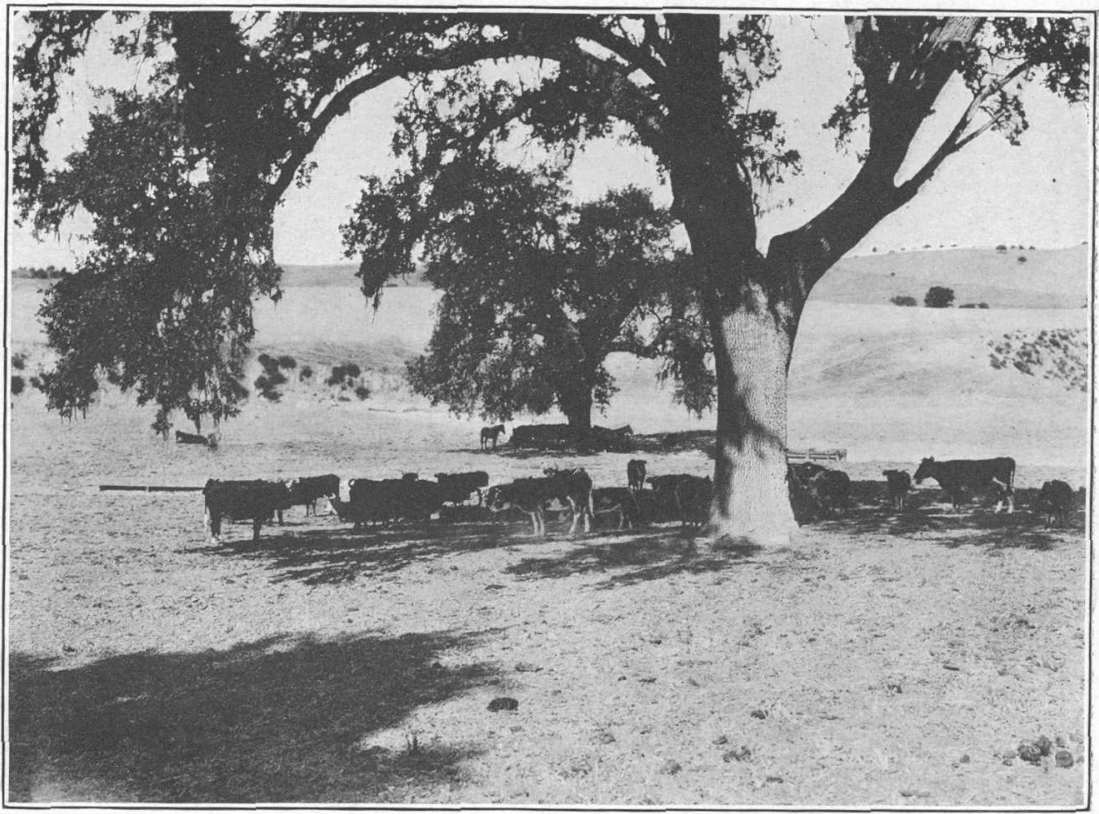

A. ALLUVIAL FLAT AND TERRACE OF SALINAS RIVER NEAR BRADLEY, CAL.

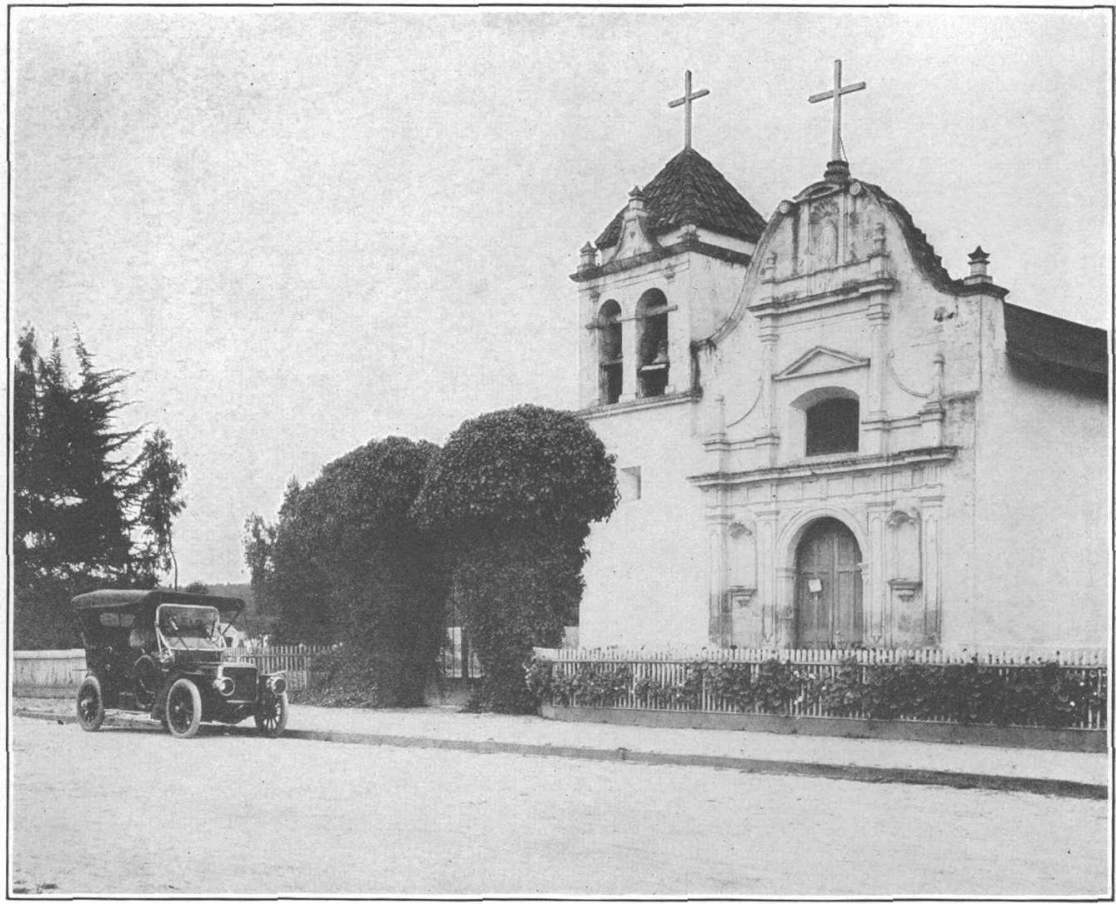

B. MISSION OF SAN CARLOS DE MONTEREY, FOUNDED IN 1770. 
crust with a fault along its northeast edge and probably another along its southwest edge, under the valley. The surface of this slope is covered with the Paso Robles formation, through which the stronger streams have cut into the underlying Santa Margarita formation.

The Paso Robles formation forms the near hills on both sides of the river between San Miguel and Bradley. Just north of the mouth of Indian Valley, at Chanslor (205.5 miles from San Francisco) there is an excellent example of one of the landslides which frequently occur in the soft Paso Robles formation when.it has been undermined by stream erosion.

From McKay a branch railroad runs to the Stone Canyon coal mine (24 miles), now worked only in a small way to supply local demand. The coal of Stone Canyon occurs in the lower part of the Vaqueros sandstone and is the best in California. In places the bed is 16 feet thick, and if it were not for the abundant supply of oil in the State the coal would probably again be mined for shipment.

Near the mouth of Sierra River (on the left) the railroad bears to the right and crosses Salinas River on a steel bridge that was partly washed away in 1913. Two of the old steel spans may be seen lying in the river to the left. Very little water flows over the sandy river bed in summer, but there is a large flow beneath the surface.

Bradley, though a small town, is the center of a considerable cattle industry. The alluvial flat and terrace of Salinas River in this vicinity are shown in Plate XXIX; $A$. Beginning

Bradley.

Elevation 538 feet. Population 442.

Los Angeles 279 miles. about $2 \frac{1}{2}$ miles northwest of Bradley there are indications of a line of disturbance, apparently a great fault, along the west side of Salinas Valley. A little farther on, at 192.5 miles from San Francisco, the prominent bluffs on the right (east) are of the Paso Robles formation and the hills on the left, across the river, are composed largely of the Monterey shale. Inasmuch as the Paso Robles normally overlies the Monterey, their occurrence so close together at nearly the same level suggests that there is an extensive fault between them, along the river. That a large fault occurs along the west border of the Salinas Valley is indicated also by the presence of a line of springs in that region. Many of these springs are hot, and some of them; as at Paso Robles and Paraiso (pa-ra-ee'so, Spanish for paradise), have been improved as health resorts. Along this fault line the great earth block previously referred to as sloping up toward the crest of the Gabilan Range on the northeast side of the Salinas Valley must have dropped down, bringing the Paso Robles gravels into juxtaposition with the Monterey and Santa Margarita (Miocene) beds and providing the structural conditions for the subsequent erosion of the long, straight valley. 
About 35 miles almost due west of Bradley is the Mansfield mining district, where some coarse gold has been recovered from stream beds. The gold is probably derived from quartz veins in igneous rocks of the Franciscan group. Some nuggets weighing several ounces are said to have come from this district. Farther southeast, toward San Luis, a number of deposits of quicksilver and chromite occur.

The village of San Ardo (see sheet 5A, p. 122) is surrounded by a wheat and stock country which includes the rolling low hills along the river. An exposure of the Santa Margarita forma-

San Ardo.

Elevation 452 feet. Population 365.*

Los Angeles 292 miles. tion begins about 6 miles south of San Ardo and extends in a northwesterly direction to a point on the west edge of the valley immediately opposite San Ardo: This strip of Santa Margarita beds consista of white sandstone that at several localities contains fossils. The geologic structure immediately west of San Ardo is complex. The hills for several miles back from the river on the west side are composed of Monterey shale.

Three miles northwest of San Ardo the Paso Robles gravels on the east side of the valley give place to sandstones of the Santa Margarita formation, which occupy an area of many square San Lucas.

Elevation 395 feeu. Los Angeles 302 miles. miles extending in a northeasterly direction from San Lucas. Fossils, including numerous sea urchins and oysters, occur at several points throughout the area. The Santa Lucia Range, which bounds Salinas Valley on the southwest, culminates in Santa Lucia Peak and Vaquero Peak, in the region west of San Lucas. The upper slopes of these mountains consist of coarse heavy-bedded fossiliferous Vaqueros sandstone dipping toward the valley. This sandstone, toward the railroad, is overlain by the upper formation of the Monterey group. Along the northeast edge of Salinas Valley the Monterey in turn is overlain by the Paso Robles formation, which either rests directly on the Monterey or at some places on intervening beds of the Santa Margarita formation.

Extending north for 3 miles and west for 4 or 5 miles from San Lucas is a gravel terrace probably deposited by the river at an earlier stage in its history.

King City is a shipping point for gypsum obtained from the hills, 15 miles to the north-northeast. At Elsa, 3 miles farther north, the sugar-beet industry is important, and on the left

\section{King City.}

Elevation 330 feet. Population 1,563.* Los Angeles 311 miles. may be seen at a distance one of the large sugar factories. The Paso Robles gravels continue to occupy both sides of the Salinas Valley to a point within 3 miles of Metz. From Chalone Creek, which is crossed at Metz, northward the main Gabilan Range becomes more rugged and consists chiefly of granite with some schist and crystalline lime- 
EXPLANATION

A Stream deposits (gravel and fine alluvium)

B Marine terrace deposits and dune sand

C Conglomerate, sandy and marly clays (Paso Robles formation), sandstone, flinty shale, and voleanie as Pismo and Santa Margarita formations

D Siliceous and bituminous diatomaceous shales of Monterey group underlain by sandstone and conglomerate Vaqueros sandstone of Monterey group

E Lava flows and fragmental volcanic material (rhyolite tuff) in shale of Monterey groun, with various intrusive dike rocks

F Sandstone with some conglomerate and shale (Chico formation), underlain by dark thin-bedded sandstones Knoxville formation

$\mathrm{G}$ Intrusive igneous rocks and derivatives diabase and serpentine) (pre-Chico but post-Francisean

H Sandstone, conglomerate, and shale, with varicolored thin-bedded flinty rocks (radiolarian chert), and schists owing their present character to changes produced by rocks (contact metarnorphism) Franciscan group

I Granite
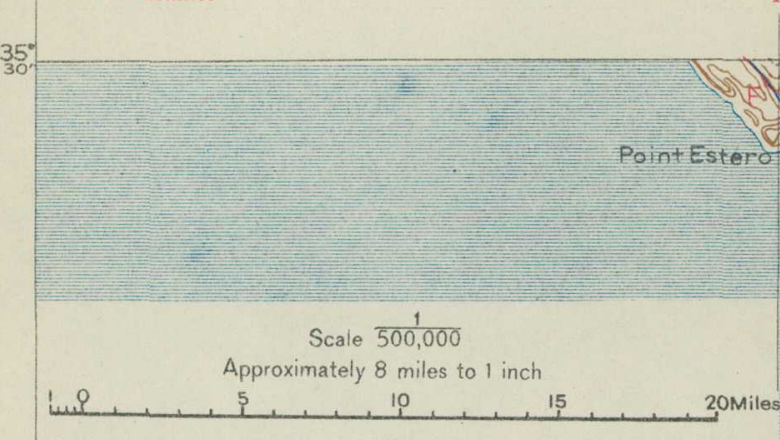

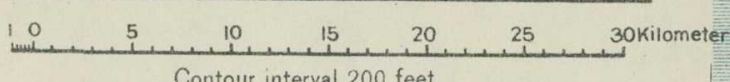 \\ Contour interval 200 feet
ELEVATIONS IN FEET ABOVE MEAN SEA LEVEL}

The distances from Los Angeles. California are shown every 10 miles

The crossties on the railroads are spaced i mile apart
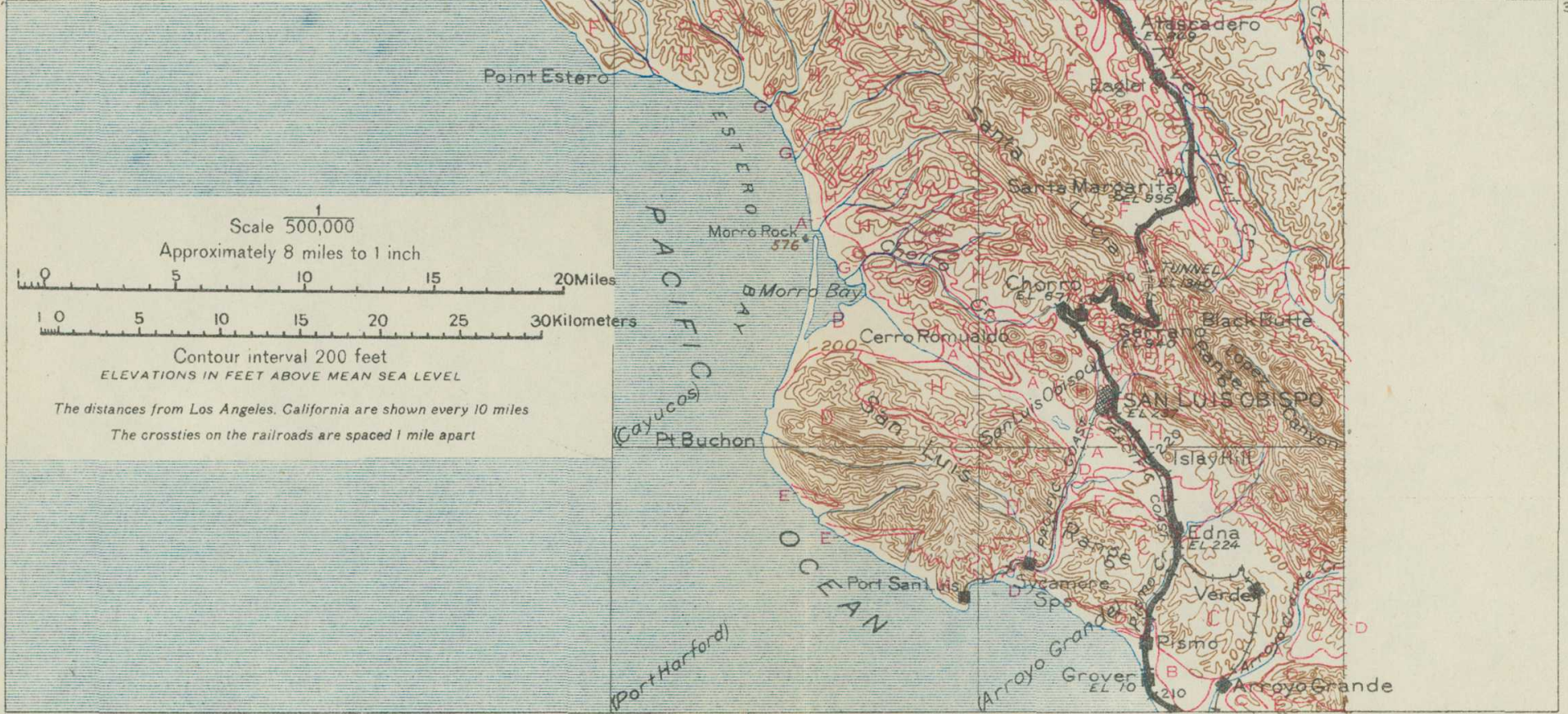

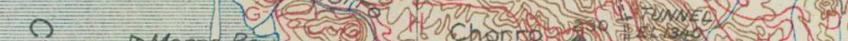




\section{GEOLOGIC AND TOPOGRAPHIC MAP}

OF THE

\section{COAST ROUTE}

\section{From Los Angeles, California, to San Francisco, California}

Base compiled from United States Geological Survey Atlas Sheets, from railroad alignments and profiles supplied by the Southern Pacific Company and from additional information collected with the assistance of this company

\section{UNITED STATES GEOLOGICAL SURVEY}

GEORGE OTIS SMITH, DIRECTOR

David White, Chief Geologist $\quad$ R. B. Marshall, Chief Geographer 1915

Each quadrangle shown on the map with a name in parenthesis in the lower left corner is mapped in detail on the U. S. G. S. Topographic. Sheet of that name. 
stone. This part of the range, which has been little studied, contains some metalliferous deposits, especially ores of quicksilver.

At milepost 147 the railroad leaves Salinas River and surmounts a terrace which borders the river for some miles. The deposits forming this terrace are comparable with those near San Lucas.

Soledad (so-lay-dahd', Spanish for solitude) is built on a fertile plain which forms part of the terrace just mentioned. From the town may

Soledad.

be had fine views of the valley and bordering moun-

Elevation 180 feet. tains, and the vicinity affords some delightful drives. Across the river are the ruins of the mission church Population 1,194**
Los Angeles 331 miles. 8 miles to Paraiso Hot Springs, at an altitude of 1,400 feet in the Santa Lucia Range. About 14 miles northeast of Soledad are The Pinnacles (Pl. XXX, p. 124), picturesque masses that have been sculptured by erosion from some rock whose character and geologic age have not been ascertained. The prominent peaks 6 or 7 miles east of Soledad are the Chalone Peaks, which are composed of marbles and other crystalline rocks that are probably older than any others in the Coast Range. North of them is an area of rocks in which copper and quicksilver occur. Flanking these peaks and extending northward along the northeast side of Salinas Valley are some hills of moderate height composed partly of sandstone.

On the west side of the Salinas Valley, opposite Soledad and Camphora, are some old alluvial fans that merge with the terrace deposits along the river. Recent erosion has cut trenches in some of these fans, but as a rule they stand out as nearly perfect examples of this type of stream deposit.

Along this part of Salinas Valley the same contact observed farther south persists; the mountain slope on the northeast is comparatively gentle, but that on the southwest is steep. The southwest slope, as previously noted, is probably a fault scarp or fault cliff, worn back and cut into by erosion.

\section{Gonzales.}

Elevation 125 feet. Population 1,305.* Los Angeles 340 miles.

Chualar.

Elevation 100 feet. Los Angeles 346 miles.

Salinas.

Elevation 41 feet. Population 3,736. Los Angeles 357 miles.

Beyond Gonzales (gohn-sah'lace), in the neighborhood of Chualar (chu-a-lar'), the valley gradually widens northwestward, toward Monterey Bay. Great quantities of alfalfa hay and grain are produced in this vicinity. The terraces found all along the Salinas Valley from Templeton northward are here well developed and grow broader toward the mouth of the river.

The town of Salinas (Spanish for salt pits) is the center of a large beet-sugar industry. Besides sugar beets, beans are extensively grown in this region, especially near the coast. Opposite Salinas the river flows at the extreme west edge of the valley. 
Del Monte Junction lies but a few miles from the mouth of Salinas River and Monterey Bay. A branch line, over Del Monte Junetion. which pass through trains to and from San FranElevation 16 feet. Los Angeles 365 miles. cisco, runs southwest from this junction to Del Monte, Monterey, and Pacific Grove. ${ }^{1}$

Some terrace deposits may be seen east of Del Monte Junction. They extend northward to the edge of Pajaro Valley, the surface apparently rising to the north. The railroad traverses a lower plain terrace descending from 16 feet at Del Monte Junction to 2 feet at Elkhorn station, beyond which it turns up a little valley cut by Elkhorn Creek in the marine terrace deposits. After crossing Elkhorn Slough and bearing to the left between some low hills, the railroad emerges, at about milepost 101, in the Pajaro Valley (pah'ha-ro, Spanish for bird).

1 The Hotel Del Monte, in grounds world-famous for their beauty, is situated on one of the most charming and interesting parts of the whole California coast. Near by are the combinations of rocks, sea, woodland, and hills such as delight an artist. Old buildings and associations appeal to the student of early California history. There are ample facilities and opportunities for the pursuit of sport of many kinds. Finally, the region is of exceptional geologic interest and is the type locality of the white shale of the Monterey group. The old mission church is built of this shale, which, although, soft when quarried, hardens on exposure and has withstood the sea air without crumbling.

Monterey, although visited and named by the Spaniards in 1602, was not permanently settled until 1770. In that year Gaspar de Portolá, the first governor of Alta California, arrived by land, and Padre Junipero Serra, of the Franciscans, a few days later by sea. Serra founded at Monterey his first mission in Upper California. The church building (PI. $\mathrm{XXIX}, B$, p. 119) is still used. The mission at Carmel, where Serra lived and died, was founded the next year. Commodore Sloat landed at Monterey July 7, 1846, and took possession for the United States. A monument to him and one to Serra stand in the Presidio. Monterey was the first capital of California, and in Colton Hall the first constitutional convention was held September 1, 1849. An association of more recent date that will endear the place to many is that here for a time lived Robert Louis Stevenson.

Monterey is the terminus of a pipe line from the Coalinga oil field, in the San Joaquin Valley, and from 12,000 to 15,000 barrels of oil is pumped through this line daily.

Soundings by the United States Coast and Geodetic Survey have shown that a deep depression extends across the bottom of the comparatively shallow Monterey Bay out to the steep submarine slope that marks the real boundary between continent and ocean. Some geologists have interpreted this depression as a valley of erosion cut by Salinas River when the land stood higher than at present and when the bottom of the bay was dry land. Prof. A. C. Lawson, however, has maintained that a similar submarine valley, in Carmel Bay south of Monterey, which is not. quite in. line with the present valley of Carmel River, is probably a structural sag or syncline and not an erosion valley at all. He can find no evidence of recent uplift of this part of the coast sufficient to have enabled the river to cut a valley across what is now the bottom of the bay. 
From Watsonville Junction (see sheet 6A, p. 130) a branch line turns to the left (west) and makes a detour through Santa Cruz and other Watsonville Junction. points, rejoining the main line to the north at San Elevation 21 feet.

Los Angeles 375 miles.

Jose. Passengers may take this route to San Francisco but will have to change cars. The Santa Cruz route affords an opportunity to see a fine group of "big trees" (PI. XXXI, p. 125), the coast redwood (Sequoia sempervirens), which, although smaller than Sequoia gigantea of the Sierra Nevada, are still gigantic, the largest measuring 70 feet in circumference. This route, crossing the Santa Cruz Mountains at an altitude of more than 1,000 feet, passes through beautiful country. The geology is complicated, old crystalline rocks and later rocks of Jurassic (?), Cretaceous, and Tertiary age being much folded and faulted. The great rift or crack (San Andreas fault) along which occurred the earthquake of 1906 is crossed by this route west of Alma.

North of Watsonville Junction the main Coast Line crosses a rich apple country, in which the orchards reach part way up the slopes of the bordering hills.

The hills to the right and left, gradually approaching as the valley narrows, are composed of Tertiary strata, with a narrow belt of Quaternary deposits along Pajaro River. Just beyond Aromas. Aromas the train enters Pajaro Gap. Here a small Los Angeles 381 miles. fault, cutting across the range, has weakened the Elevation 98 feet. rocks and thereby enabled the river to wear its way through. On the left is the river, and on the right are bluffs of crumpled and crushed rocks, largely diorite (an igneous rock resembling granite, but containing little or no quartz), which are artificially further reduced by rock crushers for railroad ballast.

The country opens abruptly as the train crosses the bridge over the Pajaro near Chittenden, and the diorite of the gorge gives place to the Tertiary sediments of the Chittenden-Sargent oil Chittenden. field. This change is due to the fact that the TerElevation 123 feet. tiary beds are much softer than the diorite and have Los Angeles 383 miles. been eroded out into a valley. Traces of the San Andreas fault, a slight recurrence of movement along which produced the earthquake of 1906, are here visible for the first time to the traveler from Los Angeles to San Francisco over the Coast Line, although the crack continues into southern California to the east of Los Angeles. The hillsides to the northwest (left) are scarred by the earthquake rift, and one-third of a mile beyond Chittenden, around a curve, on the left near the track, is a knoll blackened by the oil from a storage tank that was wrecked by the earthquake.

The Sargent oil field produces approximately 40,000 barrels a year, and some of the oil is shipped from Chittenden. The oil-bearing 
rocks--shales, sandstones, and conglomerates of the lower part of the Monterey group-cover a wide area. They are bent into anticlines and synclines and are covered by younger shales of the Monterey group and in part also by younger Miocene and Pliocene sediments. The rocks of the lower slopes near which the train passes just beyond Chittenden, on the right, are Pliocene (Merced formation). About $2 \frac{1}{2}$ miles from Chittenden, near milepost 88, San Benito River and Llagas Creek join to form Pajaro River. The railroad turns to the left up Llagas Creek to Sargent.

West of Sargent, beyond the oil field, the Franciscan rocks form the higher portions of the range. Beyond Sargent the railroad soon passes out of the low hills into the southern portion of the Sargent. Elevation 134 feet. $\quad$ alfalfa and stock country irrigated by electrio pumps,
Los Angeles 387 miles. is drained by Pajaro River to the Bay of Monterey. Across the valley in the distance can be seen Pacheco (pa-chay'co), Antimony, St. Anna, Mariposa (the highest), and other peaks of the Mount Hamilton division of the Diablo Range, which separates the Santa Clara Valley from the San Joaquin Valley.

The Santa Clara Valley extends from San Francisco Bay southeastward to and beyond San Benito, a distance of nearly 100 miles. It has a notable peculiarity in that it is divided transversely by a scarcely noticeable soil-covered divide. The southern portion is drained by Pajaro River, but the northern portion drains through Coyote River directly into San Francisco Bay, and the alluvial plain is continuous across the divide.

From Carnadero (car-na-day'ro) Junction, 4 miles beyond Sargent, a branch line runs southeast to Hollister, in San Benito Valley, where it is said there is "silver in eggs" and "gold in apples." From the junction the main line continues northward through the Santa Clara Valley to San Francisco Bay, passing through one of the most productive fruit-growing regions in the world.

The town of Gilroy is the point of departure for the Gilroy Hot Springs, which lie 13 miles to the northeast. Oaks appear about Gilroy, and alfalfa begins to give way to grain and Gilroy.

Elevation 190 feet. Population 2,437. Los Angeles 393 miles. especially to fruits. Grapes, prunes, peaches, and apricots are grown in large quantities. The mountains on the right are markedly different in aspect from those on the left, although both are composed, at least in part, of rocks belonging to the Franciscan group, partly covered by Tertiary sediments. The mountains on the right have a nearly even crest line (Pl. XXXII, p. 126). Along their base, beyond the orchards, is a much lower even-crested ridge. Between this ridge and the mountains is Coyote River, which flows northwestward to San Francisco Bay. The valley in the foreground 


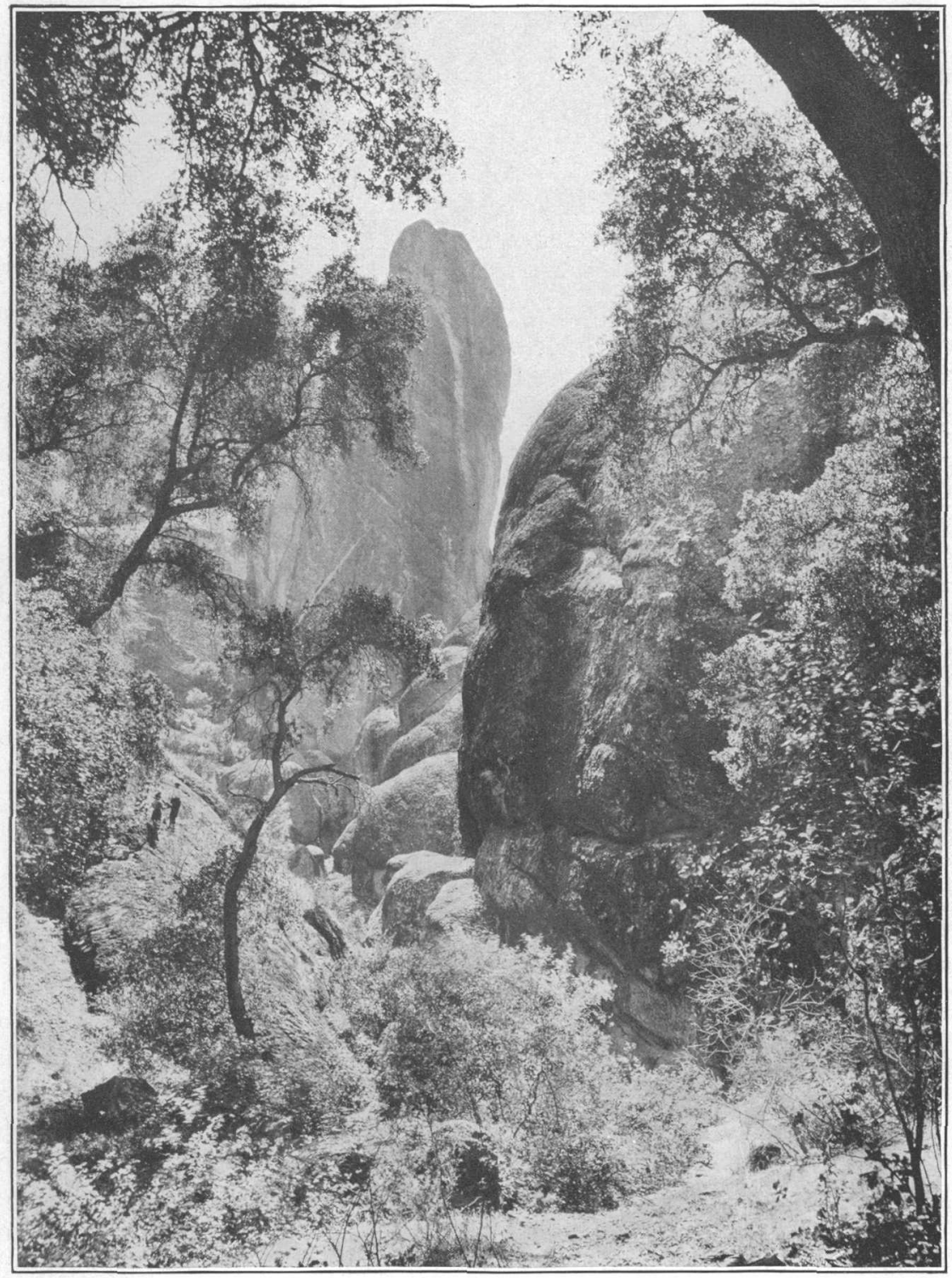

THE PINNACLES, 12 MILES NORTHEAST OF SOLEDAD, CAL.

Formed by erosion of fragmental rocks. 


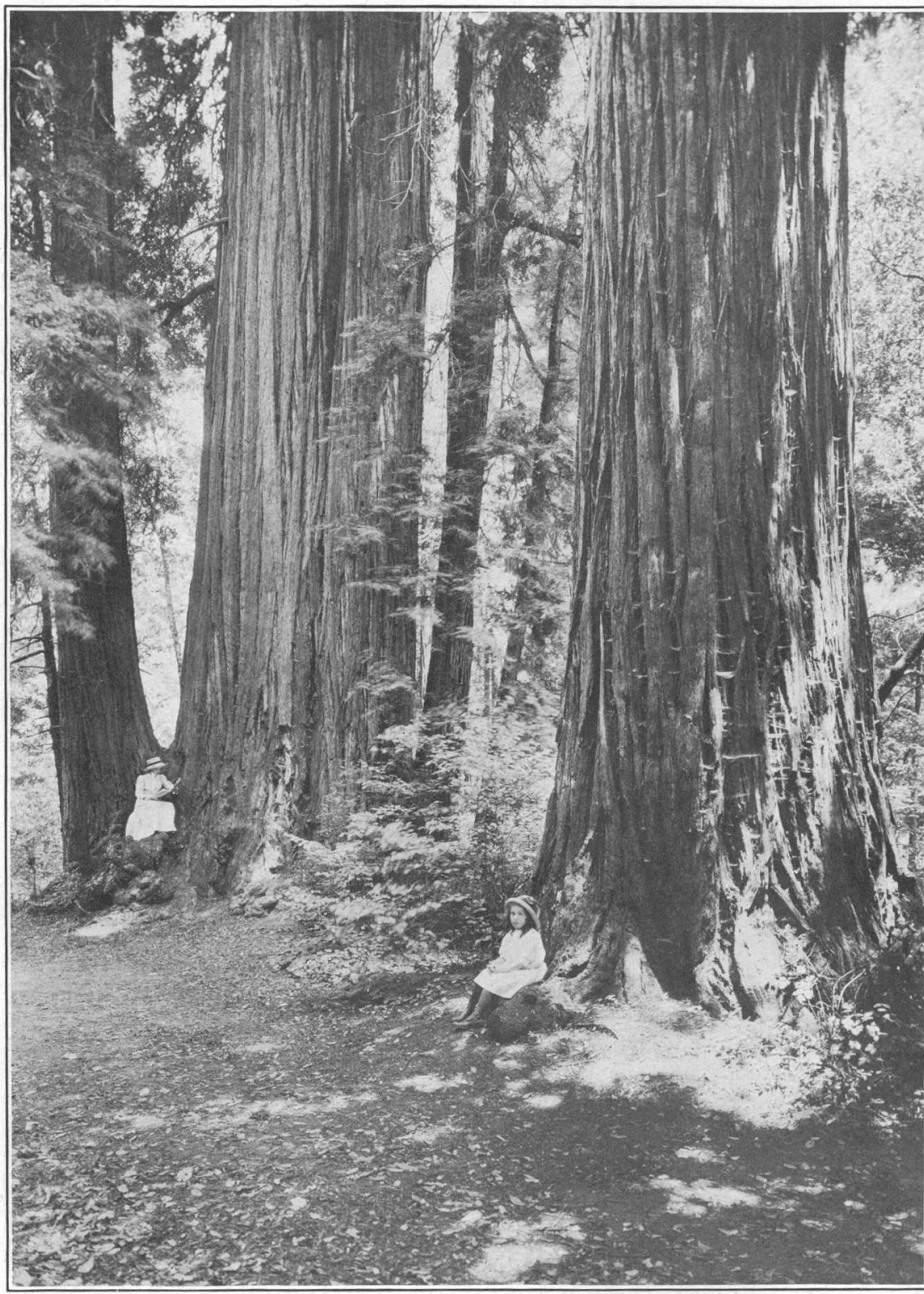

BIG TREES (SEQUOIA SEMPERVIRENS) AT SANTA CRUZ, CAL. 
is drained to the southeast by Llagas Creek to Pajaro River and 4 Monterey Bay.

At Madrone the valley narrows. The rocky slopes on the left are near the railroad and several little cuts expose serpentine, which is a characteristic accompaniment to the Franciscan Madrone.

Elevation 342 feet.

Los Angeles 405 miles. group. The summit of the transverse divide (elevation 345 feet) is reached near Perry, about 2 miles beyond Madrone, but there is no break in the continuity of the alluvial plain, and the traveler will probably not notice, unless his attention is called to it, that he is passing from the drainage basin of Pajaro River to that of Coyote River. The Coyote enters Santa Clara Valley from the mountains on the right (east).

It has been suggested that all the drainage that now finds its way into San Francisco Bay and thence to the ocean by way of the Golden Gate, once flowed southward through Santa Clara Valley to Monterey Bay. Those who maintain this view think that the submarine channel across Monterey Bay was cut by the more powerful stream that then flowed through Pajaro Valley. A striking resemblance that has been noted between the strictly fresh-water fishes and other forms of life inhabiting Sacramento and Pajaro rivers tends to confirm the conjecture that the two streams were formerly one. Later investigations by Dr. J. C. Branner, however, have suggested a different interpretation of this evidence.

A study of the material of the divide shows that it has the low conical form of an alluvial fan-that is, a deposit made by a stream where it issues from a canyon upon a plain. At such a place the velocity of the stream generally becomes less, and the water is compelled to drop much of the sand and gravel that it swept along with ease in the mountains. This particular deposit was made by Coyote River during a period (probably glacial) when the land stood at a higher level than now and the creek carried a large load of detritus. As the alluvial fan grew Coyote River shifted its position from time to time to lower parts of the conical slope, and thus flowed sometimes to San Francisco Bay and sometimes to Monterey Bay. In this way oppor-

$\sim$, tunity may have been given for fishes and other living things to pass over the divide by way of Coyote River. If this happened, it would of course not be necessary to account for the similar faunas of Sacramento and Pajaro rivers by supposing the streams to have been at one time directly united.

Six miles southwest of Coyote, in the hills composed of rocks

\section{Coyote.}

Elevation 248 feet. Population 200.

Los Angeles 412 miles. belonging to the Franciscan group, is the New Almaden quicksilver mine, which has yielded more quicksilver than any other mine in the United States. At milepost 59 on the right may be had the first view or lick Observatory, on Mount Hamilton.

The observatory may be visited from San Jose. 
Just north of Coyote is the narrowest part of - the valley. Serpentine occurs here on the left but is on the right at Edenvale, where the valley widens and a belt of Tertiary rocks forms foothills to mountains that are composed chiefly of Franciscan rocks.

At San Jose (ho-say'), which is by far the largest city in the Santa Clara Valley, the branch line running through Santa Cruz joins the main Coast Line. The New Almaden mine may be San Jose.

Elevation 85 feet. Population 28,946.

Los Angeles 424 miles. reached by a spur from this branch. Other railroad lines run from San Jose east of San Francisco Bay to Oakland and have connections across the Diablo Range, through Livermore Valley, with the several lines in San Joaquin Valley.

The city is built on the fertile plain between Guadalupe and Coyote rivers, 11 miles southeast of the head of San Francisco Bay. Its delightful climate, beauty of surroundings, fertility of soil, and consequent profusion of flowers and fruits make San Jose a favored spot even in California.

From San Jose automobile stages run to Mount Hamilton (26 miles). All the sedimentary rocks seen on this trip belong to the Franciscan group. Some beautiful drives may be enjoyed in the suburbs and in the country around the town. During the rose seasoif the drive along Alameda Avenue from San Jose to Santa Clara, about 3 miles, is particularly recommended. This trip may also be made by trolley car.

At College Park, on the left as the train leaves San Jose, is Pacific College. Well-kept orchards of prunes, apricots, peaches, pears, and cherries, as well as vineyards, lie on both sides of the railroad throughout this part of the valley. Acres of sun-drying prunes are a common sight in August.

Santa Clara College, the white building of which may be seen on the left near the center of the town of Santa Clara, was founded in 1851 by the Jesuits. The chapel is one of the old Santa Clara. mission buildings erected in 1777 and is well preElevation 69 feet. served. Several large canneries may be seen along Population 4,348.
Los Angeles 427 miles. the railroad and are kept busy for most of the year by the wide range of -fruit and vegetable products which the Santa Clara Valley affords. Two miles beyond Santa Clara on the right, barely visible in the distance across the broad fields of. barley hay and between groves of oak and eucalyptus, is . the Agnew Asylum for the Insane, a State institution.

The Santa Clara Valley widens northward and the fertile bottom land grades near the south end of the Bay of San Francisco into extensive salt marshes. The railroad bears to the west from Santa Clara, toward the mountains which form the backbone of the peninsula of San Francisco. 


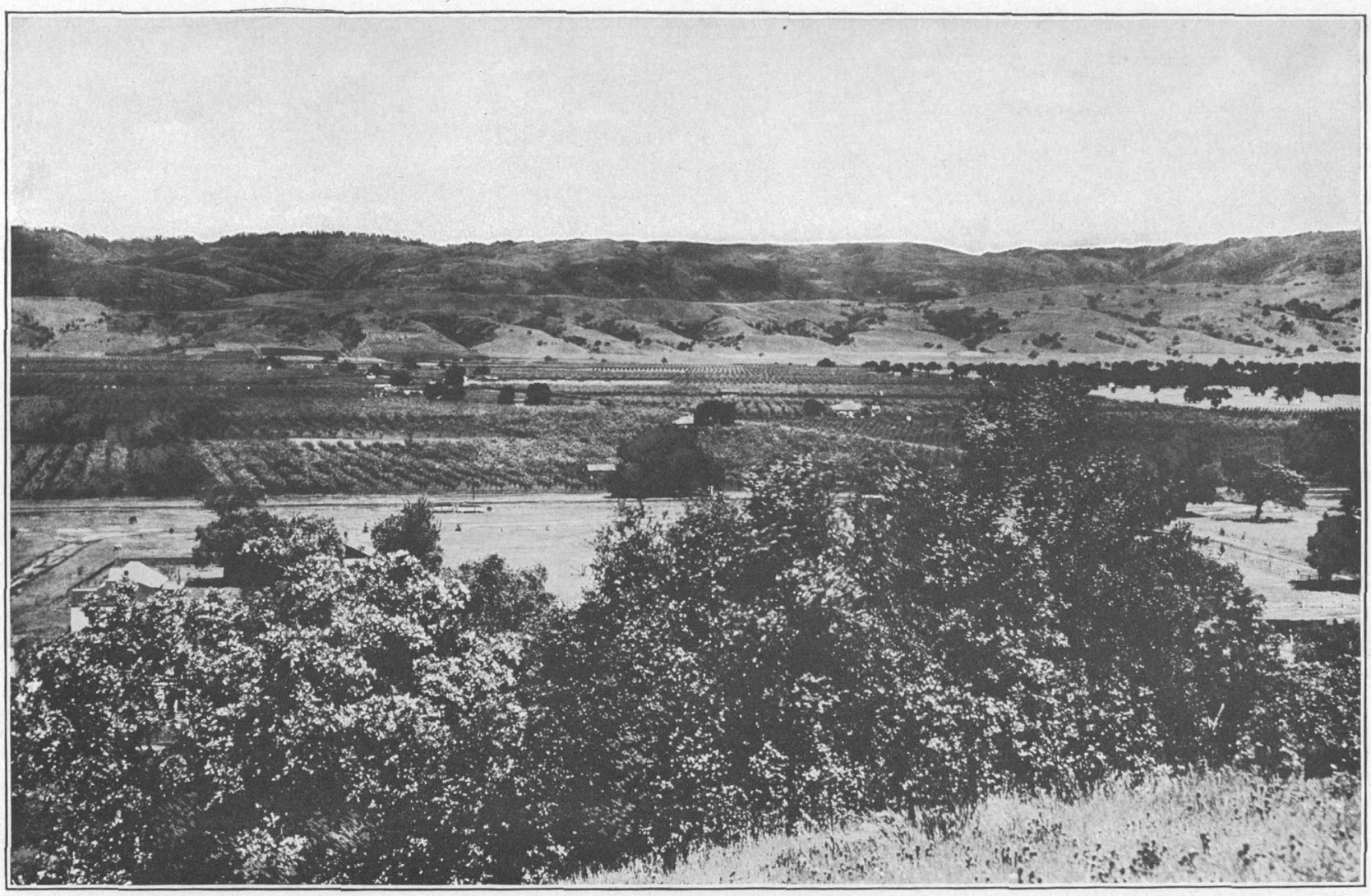

SANTA CLARA VALLEY NEAR GILROY, CAL.

The even crest of the distant ridge of Franciscan rocks suggests a plain of erosion. The narrow valley between the two distant ridges is due to faulting and contains Coyote
Pistor 


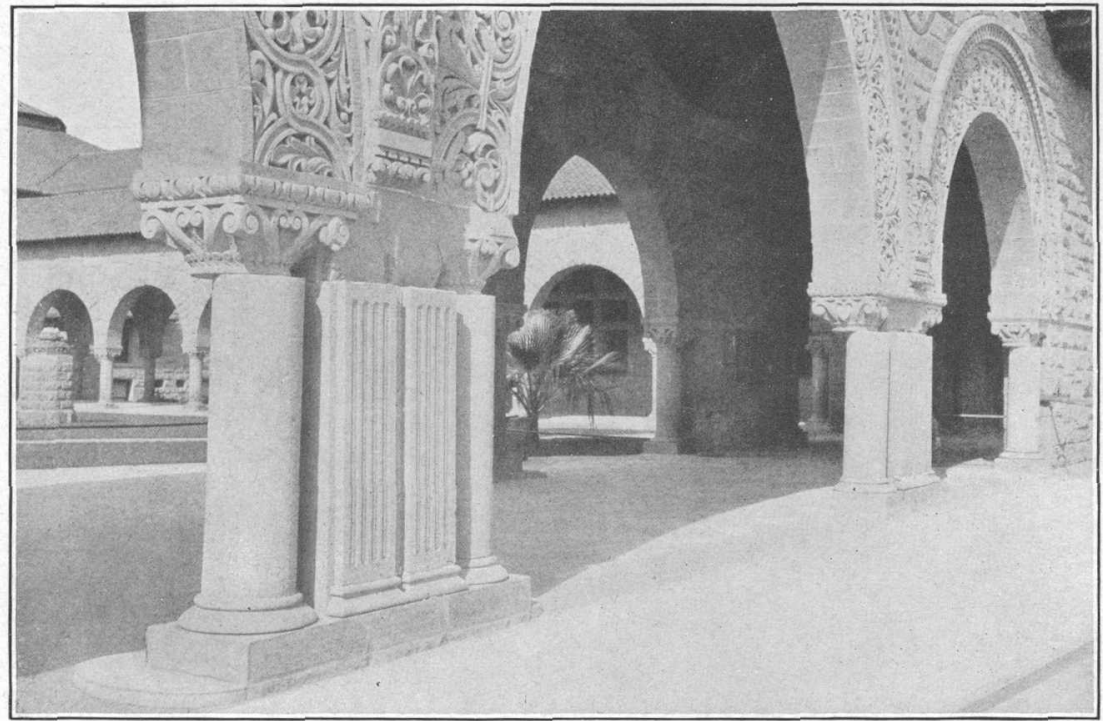

A. THE ARCHES, STANFORD UNIVERSITY, CAL.

The displacement of the capitals of the small columns supporting the arches is an effect of the earthquake of 1906.

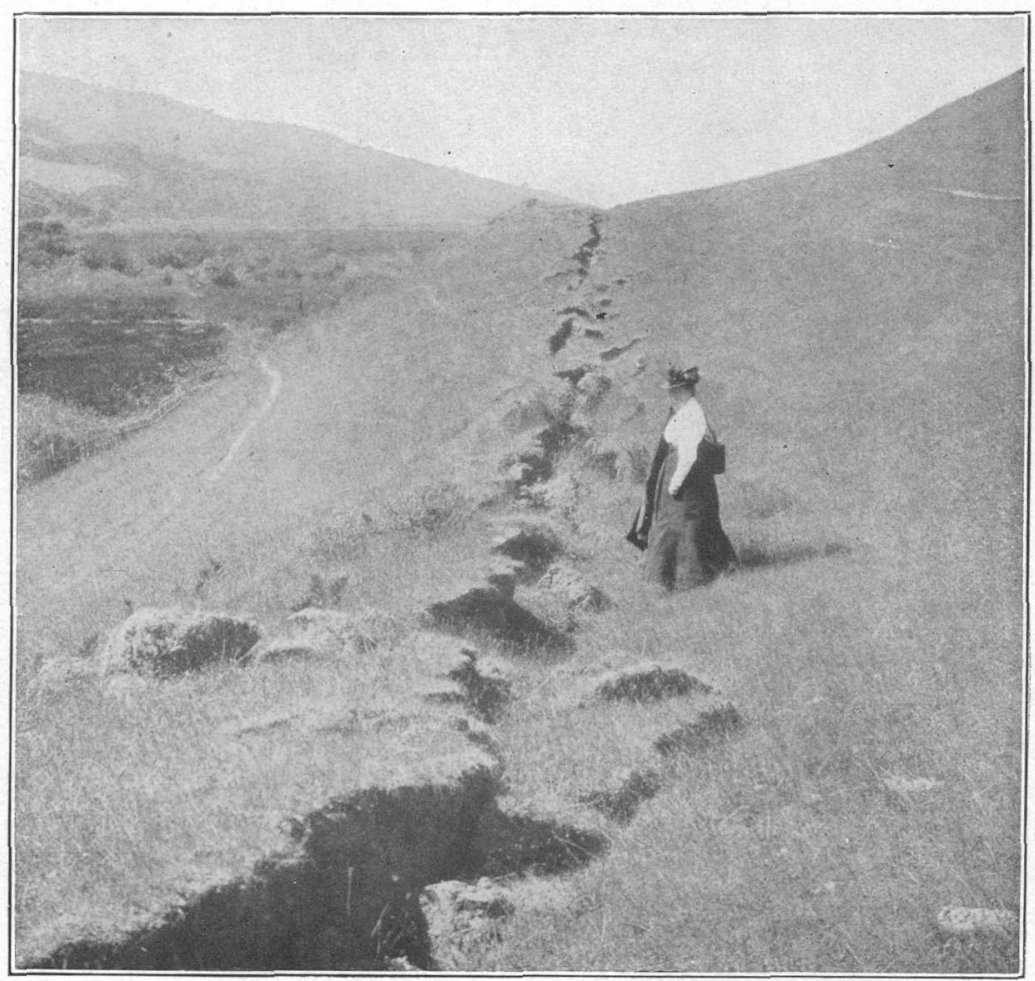

B. FURROW A MILE NORTHWEST OF OLEMA, CAL., MADE BY THE MOVEMENT WHICH CAUSED THE EARTHQUAKE OF 1906.

On the left is the rift valley, which extends from Bolinas Lagoon to Tomales Bay and is a result partly of earlier movements, partly of erosion along a zone of crushed rocks. 
Although fields of hay with scattered oaks predominate near Sunnyvale, there are large tracts devoted to orchards and market gardens. The climate and soil of the lower Santa

\section{Sunnyvale.}

Elevation 93 feet. Population 1,859.* Los Angeles 433 miles. Clara Valley between San Jose and Sunnyvale, like that of Lompoc Valley (p. 111), are such that seeds mature well, and there are several large seed farms near Sunnyvale and Santa Clara.

Near Mountain. View the railroad runs nearer to the foothills of the Santa Cruz Range. The lowest hills are composed of sandstone belonging to the lower part of the Monterey group. Mountain View. Black Mountain (elevation 2,787 feet), the culminatElevation 76 feet. Population 1,161. Los Angeles 435 miles. ing point of Monte Bello Ridge, is the most prominent peak of this part of the range. Just behind it lies the San Andreas fault or rift. (See pp. 89-90.) The upper slopes of Black Mountain are mainly sandstone with some lenticular masses of limestone, several thousand tons of which are crushed annually and shipped to beet-sugar factories. Some of the best red wine made in California is produced near Mountain View.

From Castro, about a mile beyond Mountain View, is visible on the right the Dumbarton Bridge on the railroad freight route from Oakland to San Francisco.

At milepost 33 on the left, ahead and more than a mile away, may be seen among the trees the red-tiled roofs of the Stanford University buildings. The entrance to the university grounds Palo Alto. . is on the left, near the Palo Alto station, and the uniElevation 58 feet. versity buildings, a mile away, hidden from the station Population 4,486.
Los_Angeles 441 miles. by trees, may be reached by a trolley line. Leland Los.Angeles 441 miles. Stanford Junior University, founded by Senator and Mrs. Stanford and opened in 1891, has nearly 2,000 students, both men and women. The medical department is in San Francisco and the marine biological laboratory at Pacific Grove. The buildings of the other departments are on the Stanford University tract, which embraces 8,400 acres. The buildings (see Pl. XXXIII, $A$ ), designed originally by $\mathrm{H}$. H. Richardson, take. their architectural motif from the cloisters of the San Antonio mission, and the combination of buff sandstone with red tiled roofs gives striking color effects. The buff sandstone came from the quarries at Graystone, about 10 miles south of San Jose, and is of early Miocene (Monterey). age. The San Andreas fault, the line of the San Francisco earthquake, lies 4 miles southwest of Stanford University and is easily reached from that point. The university suffered much from the earthquake but has completely recovered.

The accompanying cross section from Palo Alto to the summit of Santa Cruz Mountains (fig. 15, p. 128) shows the general geologic structure of the region. 
By looking ahead from the Palo Alto station the traveler may see on the right of the track the tall tree (Spanish, palo alto) for which

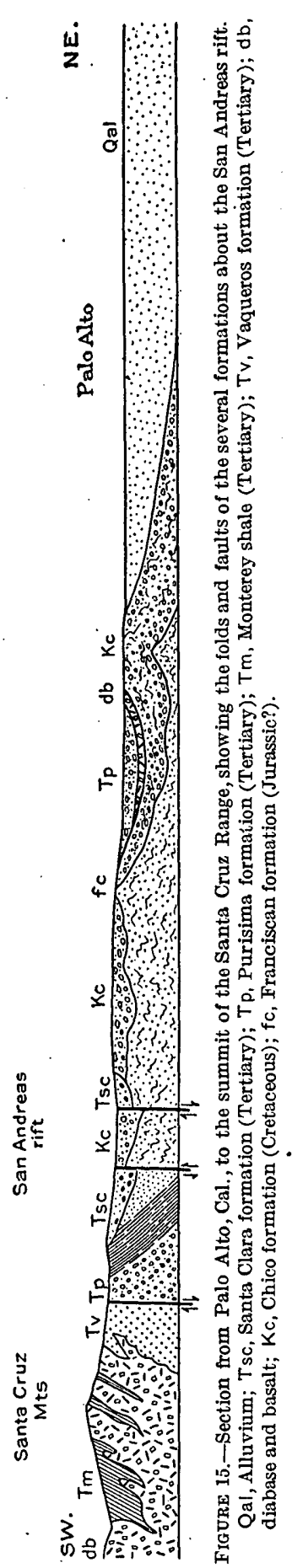
Senator Stanford's estate was named. It is the only redwood (Sequoia sempervirens) near the main line of the railroad. It stands on the bank of San Francisquito Creek, and the Southern Pacific Co. has built a wall of concrete to protect it from floods.

In Menlo Park, a village of beautiful parks and grounds, reside many well-to-do business and professional men who pass their working Menlo Park. the right, near the bay beyond days in San Francisco. On Population 820 .

Los Angeles 442 miles. Menlo Park, is a large tannery, and far out in the marsh a station for drying Alaskan codfish.

The town of Redwood was formerly the center of the redwood lumber industry of the Santa Cruz Range, then completely forested. Most of the redwood trees are

Redwood. gone, but a few of them can Elevation 7 feet. be seen scattered along the Population 4,299 .
Los Angeles 445 miles. trees in view, however, are largely a second growth. On the left, near Redwood, is a factory where magnesite is ground.

Between Redwood and San Carlos there is a good view to the left (west) of an evencrested ridge well clothed with forest. This is Cahill Ridge. Between it and the rounded oak-strewn foothills that lie nearer to the railroad is the narrow; rectilinear valley of the San Andreas rift. Two lakes, San Andreas and Crystal Springs, have been formed in this part of the valley by damming and supply much of the water used in San Francisco.

Just beyond San Carlos, on the left (west), is an iron standpipe forming part of the watersupply system of San Francisco, and below

\section{San Carlos.}

Elevation 25 feet. Los Angeles 447 miles. it, near the railroad, is one of the pumping stations. Here the oak-crowned hills composed of sandstones and other rocks bay and leave only a narrow belt of alluvium between the foothills and the salt marshes. 
Soon after leaving Belmont the train passes through a shallow cut in sandstones and cherts of the Franciscan group. The chert is

Belmont.

quarried for use on roads. Half a mile beyond Bel-

Flevation 30 feet.

Los Angeles 449 miles.

mont there is an extensive view to the right across the marshes and bay to the white salt fields of the Union Salt Works, where salt is obtained by solar evaporation of water from the bay. Along this portion of the salt marsh bordering the bay fresh water is obtained from wells of various depths up to 400 feet. This water evidently lies below the salt water. Generally the fresh water can be obtained

Beresford (Cottrell post office).

Los Angeles 450 miles. from these wells only by pumping, but at high tide, when the flats are covered by salt water, which is heavier than fresh, the hydrostatic pressure of the salt water on the deeper fresh water makes some of the wells overflow.

At Leslie there are artificial ponds (vats) in which the water of the bay is evaporated for salt. In the mill close by the salt is refined and Leslie.

Los Angeles 451 miles.

prepared for market at the rate of about 8 carloads a day. The bay water contains only about half as much salt as an equal volume of ocean water, but there are so many more bright days in this locality than there are along the coast that it is more profitable to use the weaker brine.

San Mateo (ma-tay'o) is a pretty town noted for its beautiful live oaks and handsome suburban residences. Here the road crosses

San Mateo.

Elevation 19 feet.

Population 4,384.

Los Angeles 452 miles.

San Mateo Creek, which, at the point where it issues from the San Andreas rift valley, about $3 \frac{1}{2}$ miles southwest of San Mateo, has been dammed by a high concrete structure that holds back the waters of Crystal Springs Lake.

A daily stage plies between San Mateo and Pescadero (pes-caday'ro, Spanjsh for fishmonger), near Pebble Beach on the coast, a distance of 33 miles. This stage ascends the valley of San Mateo Creek and crosses Crystal Springs Lake on a dividing dam, made of earth, which was cut and displaced by the movement along the fault at the time of the San Francisco earthquake but was soon repaired. The road to Pescadero passes near the interesting old village of Spanishtown and reaches the coast at Pebble Beach, noted for its agate pebbles. The trip from Pescadero to San Mateo may be conveniently taken in connection with one from San Francisco to Pescadero by the Ocean Shore Railroad.

At Burlingame (pronounced locally bling'um), a place of residence in favor with people of wealth and leisure, there is

\section{Burlingame.}

Elevation 26 feet. Population 1,565. Los Angeles 454 miles. a country club, with golf links and polo grounds. (See sheet 13, p. 90.) In this vicinity, as elsewhere in California south of San Francisco, there are three trees which figure characteristically in the land-
ralian eucalyptus, the Peruvian pepper tree, and the scape-the Australian eucalyptus, the Peruvian pepper tree, and the $96286^{\circ}-$ Bull. $614-15-9$ 
sturdy native oak. The eucalyptus, a tall, slim tree that is rather untidy about its bark, grows rapidly and is much used not only along the roadsides but as windbreaks. The pepper tree, which has pendant plumose foliage, is highly ornamental and is largely used in cities as a street tree and in parks and gardens. But of all the trees that adorn the fertile bottom lands of the great interior valleys the native valley oak (Quercus lobata) is by far the most important.

The large hay ranch on the left (west) near Millbrae belongs to the estate of the late D. O. Mills, a well-known capitalist and philanthropist. On the right in the bay are the oyster beds of Millbrae.

Elevation 8 feet. Los Angeles 457 miles. the Morgan Oyster Co. The native oyster is small and of coppery flavor, and although esteemed by epicures for oyster cocktails is generally inferior to the eastern oyster. Attempts to establish colonies of eastern oysters on the Pacific coast have been unsuccessful. The young oysters, or spat, however, are brought from the Atlantic seaboard and are matured on the western coast.

Ahead is San Bruno Mountain, beyond which lies San Francisco. On the left are some parallel ridges running northwest. The nearest is Buriburi Ridge (elevation 700 feet), composed of sandstones and shales of the Merced formation (Pliocene), underlain by Franciscan sandstones and igneous rocks, which form the mass of the ridge. Beyond is Sawyer Ridge (1,100 feet), consisting of Franciscan rocks. In the valley between them, 13 miles southwest of Millbrae, is San Andreas Lake.

At San Bruno the railroad branches. The main line (a cut-off), built only a few years ago and now used for the through traffic, bears

San Bruno.

Elevation 19 feet. Los Angeles 459 miles. to the right along the bay shore around the east end of San Bruno Mountain and through five tunnels reaches the station at Third and Townsend streets in San Francisco. The old line bears to the left up Merced Valley and around the west end of San Bruno Mountain and by a heavier grade and greater distance reaches the same station.

The San Francisco Peninsula, at whose northern extremity is the city of San Francisco, is divided into two parts by the northwestwardtrending Merced Valley. Each of these parts is a block of the earth's crust with a fault along its southwest side, upheaved along that side so that it has a gentle slope to the northeast. Both fault blocks have been much carved and worn by erosion so that their original blocklike character has been in great part lost. Both are composed of pre-Tertiary rocks, and the valley between them is filled with the Merced formation (Pliocene), covered for the most part by alluvium. The fault which limits the San Bruno fault block on the southwest is concealed by the alluvium. North of San Bruno Mountain, between it and the Golden Gate, is an irregular group of hills composed of 


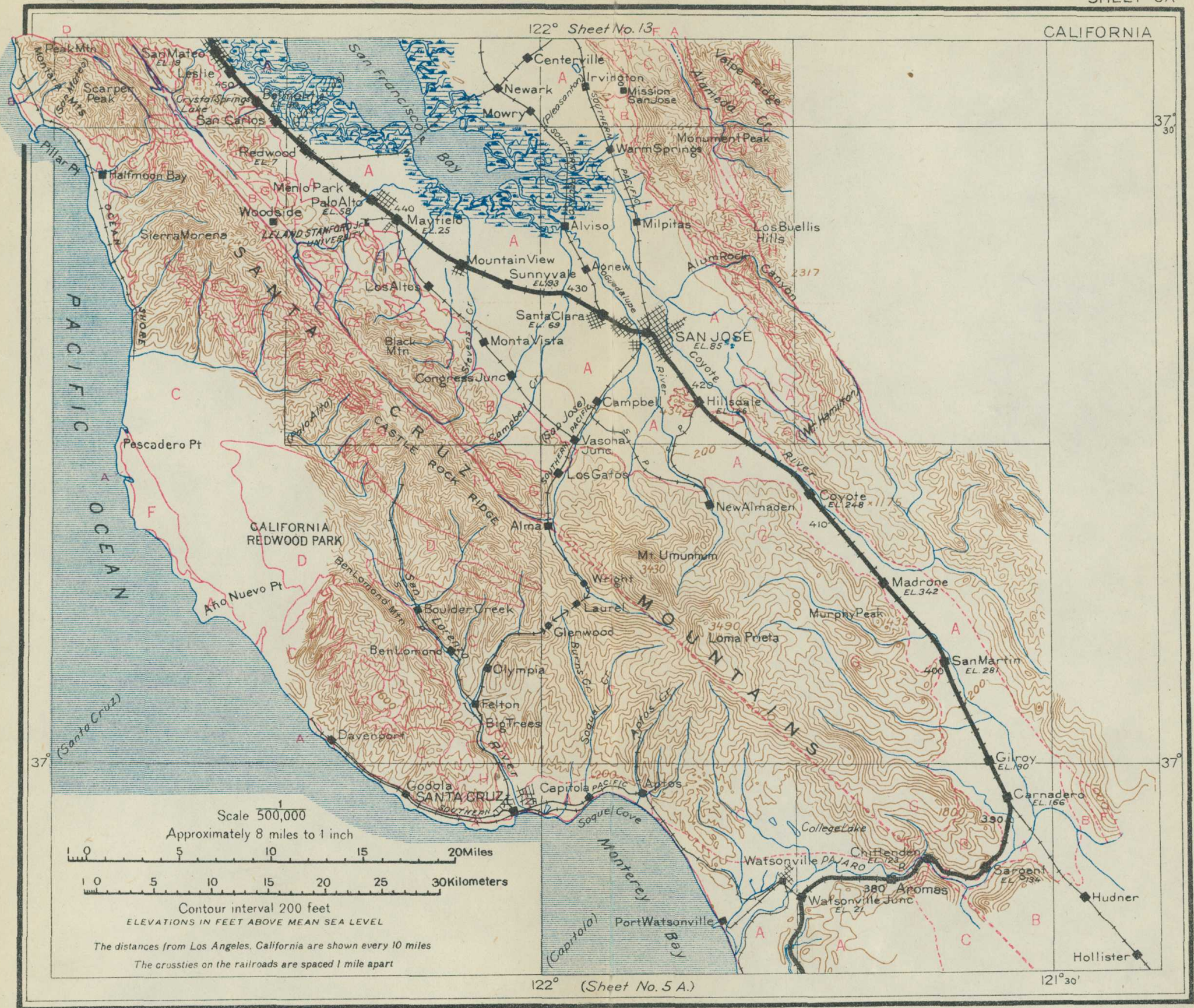




\section{GEOLOGIC AND TOPOGRAPHIC MAP}

OF THE

\section{COAST ROUTE}

\section{From Los Angeles, California, to San Francisco, California}

Base compiled from United States Geological Survey Atlas Sheets, from railroad alignments and profiles supplied by the Southern Pacific Company and from additional information collected with the assistance of this company

\section{UNITED STATES GEOLOGICAL SURVEY}

\section{GEORGE OTIS SMITH, DIRECTOR}

David White, Chief Geologist

R. B. Marshall, Chief Geographer

\section{5}

Each quadrangle shown on the map with a name in parenthesis in the lower left corner is mapped in detail on the U.S. G. S. Topographic Sheet of that name.

\section{EXPLANATION}

A Stream deposics (alluvium), sand dunes, and beach sands

B Fresh-waier gravels, sands, and clays (Santa Clara formation); marine clay, sandstone, and conglomerate (Aered formation)

C Cungitunerate, sanusione, and shale (Purisima and Santa) Miargarita formations, underlain by chalky bituminous shale, in places containing flinty layers, and by massive sandstone (upper part of Monterey group) ; underlain by havay-bedded sandstone and conglomerate (Vanueros sandstone) of Monteray group (Miocene). At base clayey shales with some fine-grained sandstone (San Lorenzo formation, Oligocene)

D Hard sandstone (Tejon formation); chiefly conglom- erate with sandstone; underlain by shale and thin limestone (Martinaz formation)

$E$. Lava flows (bnsalt and rhyolite)

F. Massive yellowish sandstone with conglomerate at bottom (Chico formation, Upper Cretaceous), underlain by limy and sandy snale (knoxville formation, Iower Cretaceuus)

G Intrusive rocks and derivatives (diabase, gabbro, peridotite, pyroxenite, serpentine)

Quaternary

Early Qua-

ternary and Plicenene

Miocene

and

Oligocene

Eocene

Tertiary

Cretaceous

Jurassic (?)

Jurassic(?) bedded flinty rocks (radiolarian cherts) and some limesiwne. Locally changed to schists near contact with igneùs rosks. (Franciscan group)

I White to light-gray crystalline limestone and miraceous schist

J Granite (quartz diorite)
Pre-Jurassic(?)

Pre-Jurassic(?) 
Franciscan rocks and dune sand. On and between these hills is the city of San Francisco.

South San Francisco is a manufacturing town, whose chief industry is the refrigeration and preparation of meats. Here also there are steel, glazing and terra-cotta, brick, paint, pipe, South San Franciseo. and ice works.

Elevation 11 feet.

I.os $A$ ngeles 461 miles.

The five tunnels between South San Francisco and San Francisco are from 1,088 to 3,547 feet in length. All are in rocks of the Franciscan group. The first, through Sierra Point, is in sandstone, of which there is a fine exposure in an open cut beyond the tunnel. The second, the longest tunnel, penetrates a complex ridge of sandstone, radiolarian chert, and diabase. The large railroad traffic near San Francisco is indicated by the great freight yards in Visitation Valley, between the second and third tunnels. As the train emerges from the third tunnel, which is in sandstone, Hunter Point appears ahead. Beyond Hunter Point, on the left (west), across the salt marsh of Islais (ees-lah'ees) Creek, is the city garbage incinerator. The last two tunnels are in serpentine. Near the new terminal station a sugar refinery and the Union Iron Works, where the famous battleship Oregon and many other warships have been built, are to be seen on the right.

A short description of San Francisco is given on pages 86-87. 


\section{SOME PUBLICATIONS ON WEST-COAST GEOLOGY.}

Anderson, F. M., Cretaceous deposits of the Pacific coast: California Acad. Sci.

Proc., 3d ser., vol. 2, No. 1, pp. 1-154, 1902.

ArNold, RALPH, Geology and oil resources of the Summerland district, Santa Barbara

County, Cal.: U. S. Geol. Survey Bull. 321, 1907.

Arnold, Ralph, and Anderson, Robert, Geology and oil resources of the Santa Maria oil district, Santa Barbara County, Cal.: U. S. Geol. Survey Bull. 322, 1907.

Arnold, RalPh, and Hannibal, Harold, The marine Tertiary stratigraphy of the north Pacific coast of America: Am. Philos. Soc. Proc., vol. 52, pp. 559-605, 1913.

Branner, J. C., Newsom, J. F., and Arnold, Ralph, U. S. Geol. Survey Geol. Atlas, Santa Cruz folio (No. 163), 1909.

Bretz, J. H., Glaciation of Puget Sound: Washington Geol. Survey Bull. 8, 1913. Contains list of publications.

Condon, Thomas, Oregon geology, a revision of The two islands, edited by Ellen Condon McCormack, 1910.

Darton, N. H., The structural materials of Oregon and Washington: U. S. Geol. Survey Bull. 387, 1909.

Drluer, J. S., U. S. Geol. Survey Geol. Atlas, Lassen Peak folio (No. 15), 1895.

- A geological reconnaissance in northwestern Oregon: U. S. Geol. Survey Seventeenth Ann. Rept., pt. 1, pp. 447-520, 1896.

U. S. Geol. Survey Geol. Atlas, Roseburg folio (No. 49), 1898.

U. S. Geol. Survey Geol. Atlas, Redding folio (No. 138), 1906.

Geological history of Crater Lake: U. S. Dept. Interior, 1912.

Mineral resources of southwestern Oregon: U. S. Geol. Survey Bull. 546, 1914.

Eldridge, G. H., and Arnold, Ralph, The Santa Clara Valley, Puente Hills, and Los Angeles oil districts, southern California: U. S. Geol. Survey Bull. 309, 1907.

Fairbanks, H. W., U. S. Geol. Survey Geol. Atlas, San Luis folio (No. 101), 1904.

Landes, Henry, and Ruddy, C. A., Coal deposits of Washington: Washington Geol. Survey Ann. Rept. for 1902.

Lawson, A. C., Report of the California State Earthquake Investigation Commission: Carnegie Inst. Washington Pub. 87, 1908.

U. S. Geol. Survey Geol. Atlas, San Francisco folio (No. 193), 1914.

Matthes, F. E., Mount Rainier and its glaciers: U. S. Dept. Interior, 1914.

Oregon Bureau of Mines and Geology, Mineral resources of Oregon, vol. 1, 1914.

Osmonr, V. C., A geological section of the Coast Ranges north of the Bay of San Francisco: California Univ. Dept. Geology Bull., vol. 4, No. 3, pp. 37-87, 1904.

Ransome, F. L., The Great Valley of California, a criticism of the theory of isostasy: California Univ. Dept. Geology Bull., vol. 1, pp. 371-428, 1896.

Russell, I. C., and Smith, G. O., Glaciers [and rocks] of Mount Rainier: U. S. Geol. Survey Eighteenth Ann. Rept., pt. 2, pp. 349-424, 1898.

Smith, G. O., The coal of the Pacific coast: U. S. Geol. Survey Twenty-second Ann. Rept., pt. 3, pp. 473-513, 1902.

Smith, G. O., and Willis, Balley, Contributions to the geology of Washington: U. S. Geol. Survey Prof. Paper 19, $190 \dot{3}$.

Stanton, T. W., Fauna of the Knoxville beds: U. S. Geol. Survey Bull. 133, 1896.

Weaver, C. E., A report on the Tertiary paleontology of western Washington: Washington Geol. Survey Bull. 13, in preparation, 1914.

Wildis, Balley, and Smith, G. O., U. S. Geol. Survey Geol. Atlas, Tacoma folio (No. 54), 1899. 


\section{GLOSSARY OF GEOLOGIC TERMS.}

Alluvial fan. The outspread sloping deposit of bowlders, gravel, and sand left by a stream where it passes from a gorge out upon a plain,

Andesite. A lava of widespread occurrence, usually of dark-gray color and intermediate in chemical composition between rhyolite and basalt.

Anticline. An arch of bedded or layered rock suggestive in form of an overturned canoe. (See fig. 3, p. 18.) (See also Dome and Syncline.)

Badlands. A region nearly devoid of vegetation where erosion, instead of carving hills and valleys of the familiar type, has cut the land into an intricate maze of narrow ravines and sharp crests and pinnacles. Travel across such a region is almost impossible; hence the name.

Basalt. A common lava of dark color and of great fluidity when molten. Basalt is less siliceous than granite and rhyolite, and contains much more iron, calcium, and magnesium.

Bolson (pronounced bowl-sown'). A flat-floored desert valley that drains to a central evaporation pan or playa.

Bomb. See Volcanic bomb.

Breccia (pronounced bretch'a). A mass of naturally cemented angular rock fragments.

Crystalline rock. A rock composed of closely fitting mineral crystals that have formed in the rock substance as contrasted with one made up of cemented grains of sand or other material or with a volcanic glass.

Diabase. A heavy, dark intrusive rock having the same composition as basalt, but, on account of its slower cooling, a more crystalline texture. Its principal constituent minerals are feldspar, augite, and usually olivine. Olivine is easily changed by weathering, and in many diabases is no longer recognizable. Augite is a mineral containing iron and magnesium and is similar to hornblende.

Dike. A mass of igneous rock that has solidified in a wide fissure or crack in the earth's crust.

Diorite. An even-grained intrusive igneous rock consisting chiefly of the minerals feldspar, hornblende, and very commonly black mica. If the rock contains much quartz, it is called quartz diorite. Quartz diorite resembles granite and is connected with that rock by many intermediato varieties, including monzonite. The feldspar in diorite differs from that in granite in containing calcium and sodium instead of potassium. Hornblende is a green or black mineral containing iron, magnesium, calcium, and other constituents.

Dip. The slope of a rock layer expressed by the angle which the top or bottom of the layer makes with a horizontal plane. (See fig. 9, p. 51.) (See also Strike.)

Dissected. Cut by erosion into hills and valleys. Applicable especially to plains or peneplains in process of erosion after an uplift:

Dome. As applied to rock layers or beds, a short anticline, suggestive of an inverted basin.

Drift. The rock fragments-soil, gravel, and silt-carried by a glacier. Drift includes the unassorted material known as till and deposits made by streams flowing from a glacier.

Erosion. The wearing away of materials at the earth's surface by the mechanical action of running water, waves, moving ice, or winds, which use rock fragments and grains as their tools or abrasives. Erosion is aided by weathering. (See Weathering.) 
Fault. A fracture in the earth's crust accompanied by movement of the rock on one side of the break past that on the other. If the fracture is inclined and the rock on one side appears to have slid down the slope of the fracture the fault is termed a normal fault. If, on the other hand, the rock on one side appears to have been shoved up the inclined plane of the break, the fault is termed a reverse fault. (See P1. XXXIII, B, p. 127; fig. 12, p. 90; fig. 15, p. 128.)

Fault block. A part of the earth's crust bounded wholly or in part by faults.

Fault scarp. The cliff formed by a fault. Most fault scarps have been modified by erosion since the faulting.

Fauna. The animals that inhabited the world or a certain region at a certain time.

Fissure. A crack, break, or fracture in the earth's crust or in a mass of rock.

Flood plain. The nearly level land that borders a stream and is subject to occasional overflow. Flood plains are built up by sediment left by such overflows. (See Pl. XXIX, $A$, p. 119.)

Flora. The assemblage of plants growing at a given time or in a given place.

Fold. A bend in rock layers or beds. Anticlines and synclines are the common types of folds. (See fig. 15, p. 128.)

Formation. A rock layer, or a series of continuously deposited layers grouped together, regarded by the geologist as a unit for purposes of description and mapping. A formation is usually named from some place where it is exposed in its typical character. For example, Denver formation, Niobrara limestone.

Fossil. The whole or any part of an animal or plant that has been preserved in the rocks or the impression left on rock by a plant or animal. Preservation is invariably accompanied by some change in substance, and from some impressions the original substance has all been removed. (See Pl. XXV, p. 92.)

Gneiss (pronounced nice). A rock resembling granite, but with its mineral constituents so arranged as to give it a banded appearance. Most gneisses are metamorphic rocks derived from granite or other igneous rocks.

Granite. A crystalline igneous rock that has solidified slowly deep within the earth. It consists chiefly of the minerals quartz, feldspar, and one or both of the common kinds of mica, namely, black mica, or biotite, and white mica, or muscovite. The feldspar is the kind known as orthoclase, and may be distinguished from quartz by its pale reddish tint and its property of breaking with flat shining surfaces (cleavage), for quartz breaks irregularly. The micas are easily recognized by their cleavage into thin, flexible flakes and their brilliant luster.

Horizon. In geology any distinctive plane traceable from place to place in different exposures of strata and marking the same period of geologic time. A particular horizon may be characterized by distinctive fossils.

Igneous rocks. Rocks formed by the cooling and solidification of a hot liquid material, known as magma, that has originated at unknown depths within the earth. Those that have solidified beneath the surface are known as intrusive rocks, or, if the cooling has taken place slowly at great depth, as plutonic intrusive or plutonic rocks. Those that have flowed out over the surface are known as effusive rocks, extrusive rocks; or lavas. The term volcanic rocks includes not only lavas but bombs, pumice, tuff, volcanic ash, and other fragmental materials or ejecta thrown out from volcances.

Lithologic. Pertaining to lithology, or the study of rocks. (See also Petrology.) Pertaining to rock character.

Lode. An ore-bearing vein (see Vein); especially a broad or complex vein.

Loess (pronounced lurse with the $r$ obscure). A fine homogeneous silt or loam showing usually no division into layers and forming thick and extensive deposits in the Mississippi Valley and in China. 'It is generally regarded as in part at least a deposit of wind-blown dust. 
Meander. To flow in serpentine curves. A loop in a stream. The term comes from the Greek name of a river in Asia Minor, which has a sinuous course. Most streams in flowing across plains develop meanders.

Metamorphism. Any change in rocks effected in the earth by heat, pressure, solutions, or gases. A common cause of the metamorphism of rocks is the intrusion into them of igneous rocks. Rocks so changed are termed metamorphic.

Monzonite. An even-grained intrusive igneous rock intermediate in character between diorite and granite. It resembles granite.

Moraine. A mass of drift deposited by a glacier at its end or along its sides.

Oil pool. An area or body of sedimentary rock that yields petroleum on drilling. The oil occurs in the pores of the rock and is not a pool or pond in the ordinary sense of these words.

Outcrop. That part of a rock that appears at the surface. The appearance of a rock at the surface or its projection above the soil.

Paleontology. The study of the world's ancient life, either plant or animal, by means of fossils.

Peneplain. A region reduced almost to a plain by the long-continued normal erosion of a land surface. It should be clistinguished from a plain produced by the attack of waves along a coast or the built-up flood plain of a river.

Petrography. The description. of rocks, especially of igneous and metamorphic rocks studied with the aid of the microscope.

Petrology. The study of rocks, especially of igneous and metamorphic rocks.

Placer deposit. A mass of gravel, sand, or similar material resulting from the crumbling and erosion of solid rocks and containing particles or nuggets of gold, platinum, tin, or other valuable minerals derived from rocks or veins by erosion.

Playa (pronounced plah'ya). The shallow central basin of a desert plain, in which water gathers after a rain and is evaporated.

Porphyry. Any igneous rock in which certain crystal constituents are distinctly visible in contrast with the finer-grained substance of the rock.

Quartzite. A rock composed of sand grains cemented by silica into an extremely hard mass.

Rhyolite. A lava, usually of light color, corresponding in chemical composition to granite. The same molten liquid that at great depth within the earth solidifies as granite would, if it flowed out on the surface, cool more quickly and crystallize less completely as rhyolite.

Schist. A rock that by subjection to heat and pressure within the earth has undergone a change in the character of the particles or minerals that compose it and has these minerals arranged in such a way that the rock splits more easily in certain directions than in others. A schist has a crystalline grain roughly similar to the grain of a piece of wood.

Sedimentary rocks. Rocks formed by the accumulation of sediment in water (aqueous deposits) or from air (eolian deposits). The sediment may consist of rock fragments or particles of various sizes (conglomerate, sandstone, shale); of the remains or products of animals or plants (certain limestones and coal); of the product of chemical action or of evaporation (salt, gypsum, etc.); or of mixtures of these materials. Some sedimentary deposits (tuffs) are composed of fragments blown from volcanoes and deposited on land or in water. A characteristic feature of sedimentary deposits is a layered structure known as bedding or stratification. Each layer is a bed or stratum. Sedimentary beds as deposited lie flat or nearly flat. (See Pl. XXVIII, p. 118.)

Shale. A rock consisting of hardened thin layers of fine mud.

Slate. A rock that by subjection to pressure within the earth has acquired the property of splitting smoothly into thin plates. The cleavage is smoother and more regular than the splitting of schist along its grain. 
Stratigraphy. The branch of geologic science that deals with the order and relations of the strata of the earth's crust.

Strike. The direction along which an inclined rock layer would meet the earth's surface if that surface were level. The outcrop (which see) of a bed on a plain is coincident with its strike.

Structure. In geology the forms assumed by sedimentary beds and igneous rocks that have been moved from their original position by forces within the earth or the forms taken by intrusive masses of igneous rock in connection with effects produced mechanically on neighboring rocks by the intrusion. Folds (anticlines and synclines) and faults are the principal mechanical effects considered under structure. Schistosity and cleavage are also structural features.

Syncline. An inverted arch of bedded or layered rock suggestive in form of a canoe.

Talus (pronounced tay'lus). The mass of loose rock fragments that accumulates at the base of a cliff or steep slope.

Terrace. A steplike bench on a hillside. Most terraces along rivers are remnants of valley bottoms formed when the land was lower or when the stream flowed at higher levels. Other terraces have been formed by waves. Some terraces have been cut in solid rock, others have been built up of sand and gravel, and still others have been partly cut and partly built up. (See Pl. XXIX, A, p. 119.)

Till. The deposit of mingled bowlders, rock fragments, and soil left behind by a melting glacier or deposited about its'margin.

Tuff. A rock consisting of a layer or layers of lava particles blown from a volcano. A fine tuff is often called volcanic ash and a coarse tuff breccia.

Type locality. The place at which a formation is typically displayed and from which it is named; also the place at which a fossil or other geologic feature is displayed in typical form.

Unconformity. A break in the regular succession of sedimentary rocks, indicated by the fact that one bed rests on the eroded surface of one or more beds which may have a distinctly different dip from the bed above. An unconformity may show that the beds below it have at some time been raised above the sea and have been eroded. In some places beds thousands of feet thick have been washed away before the land again became submerged and the first bed above the surface of unconformity was deposited. If beds of rock may be considered as leaves in the volume of geologic history, an unconformity marks a gap in the record.

vein. A mass of mineral material that has been deposited in or along a fissure in the rocks. A vein differs from a dike in that the vein material was introduced gradually by deposition from solution whereas a dike was intruded in a molten condition.

Volcanic bomb. A rounded mass of lava thrown out while in a hot and pasty condition from a volcano. A bomb, like a raindrop, is rounded in its passage through the air and may be covered with a cracked crust due to quick cooling.

Volcanic cone. A mountain or hill usually of characteristic conical form, built up around a volcanic vent. The more nearly perfect cones are composed principally of lava fragments and volcanic ashes.

Volcanic glass. Lava that has cooled and solidified before it has had time to crystallize.

Volcanic neck. A plug of lava that formerly congealed in the pipe of a volcano. When the tuffs and lava flows that make up most of a volcano have been washed away by erosion the neck may remain as an isolated hill.

Volcanic rocks. Igneous rocks erupted at or near the earth's surface, including lavas, tuffs, volcanic ashes, and like material.

Weathering. The group of processes, such as the chemical action of air and rain water and of plants and bacteria and the mechanical action of changes of temperature, whereby rocks on exposure to the weather change in character, decay, and finally crumble into soil. (See Pl. XXVII, p. 109.) 


\section{ILLUSTRATIONS.}

\section{ROUTE MAP.}

For the convenience of the traveler the sheets of the route map are so folded and placed that he can unfold them one by one and keep each one in view while he is reading the text relating to it. A reference in parentheses is given in the text at each point where a new sheet should be unfolded.

SHew 1. Seattle to Kyro, Wash...

2. Chambers Prairie to Castle Rock, Wash...................... 24

3. Ostrander, Wash., to Clackamas, Oreg................... 32

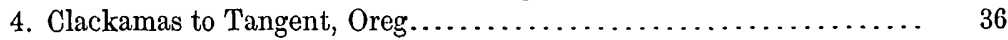

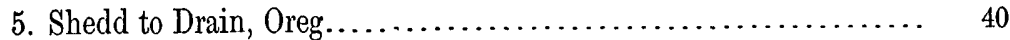

6. Yoncalla to West Fork, Oreg............................ 46

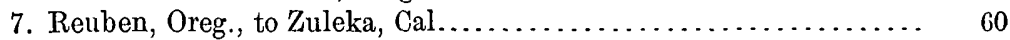

8. Hornbrook to Sims, Cal................................ 64

9. Gibson to Blunt, Cal . . . . . . . . . . .

10. Red Bluff to Delevan, Cal............................. 74

11. Maxwell to Yolo, Cal..................................... 76

12. Yolo to Port Costa, Cal . . . . . . . . . . . . . . . . . . . . . . . . $\quad 80$

13. Port Costa to San Francisco, Cal........................... 90

1A. Los Angeles to Moorpark, Cal . . . . . . . . . . . . . . . . . . . . . 102

2A. Somis to Naples, Cal................................. 110

3A. Capitan to Oceano, Cal............................... 114

4A. Grover to Wunpost, Cal............................. 120

5A. San Ardo to Del Monte Junction, Cal..................... 122

6A. Watsonville Junction to San Mateo, Cal................. 130

PLATES.

Plate I. Relief map of the country traversed by the Shasta Route and Coast

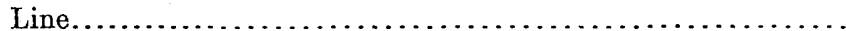

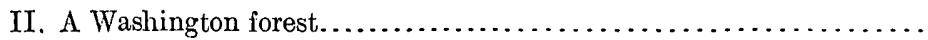

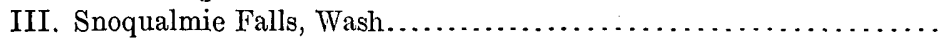

IV. $A$, Mount Rainier, Wash., from Spanaway Lake; $B$, Paradise Park, on south slope of Mount Rainier........................

V. Ocean spray (Sericotheca discolor), a common flower in Washington..

VI. $A$, Smelt fishery on Cowlitz River near Kelso, Wash.; $B$, Seining salmon on Columbia River.

Page.

VII. View up Columbia River from Columbia Highway at Chanticleer Inn, about 20 miles east of Portland, Oreg.................

VIII. Oneonta Gorge, Columbia River near. Oneonta, Oreg ............

IX. Latourelle Falls, Columbia River near Latourelle, Oreg..........

X. $A$, Trunks of trees of a submerged forest, Columbia River, above Cascade Locks, Oreg.; $B$, Cigar-shaped raft of logs for ocean travel.

XI. $A$, Mount Hood from Portland, Oreg.; $B$, Willamette Falls, Oregon

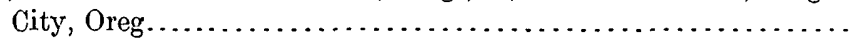

XII. Willamette Valley near Newburg, northwest of Fubbard, Oreg..... XIII. Shale inclosed in diabase near Roseburg, Oreg.................. XIV. Hydraulic placer mining in Grants Pass region, Oreg............. 
Plate XV. A, Table Rock, at entrance to Rogue River valley, Oreg.; $B$, Oregon Caves, southwest of Grants Pass, Oreg.....................

XVI. Pear and apple orchards in Rogue River valley, Oreg...........

XVII. $A$, Mount Mazama restored; $B$, Wizard Island, Crater Lake, Oreg.

XVIII. Southeast rim of Crater Lake, Oreg., from Wizard Island. .......

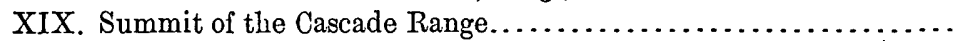

XX. $A$, Sugar Loaf, near west base of Mount Shasta, Cal.; $B$, Moss Brae

Falls, near Shasta Springs, Cal.......................

XXI. Mount Shasta, from Sisson, Cal..........................

XXII. Eruption of Lassen Peak, Cal., at 12.30 p. m. August 22, 1914.....

XXIII. New crater of Lassen Peak, Cal., after 25 eruptions within the old

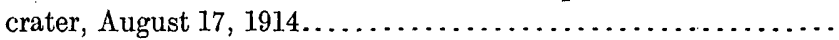

XXIV. $A$, Sinks of Suisun Flats, Cal.; $B$, View along shore of San Pablo Bay near Oleum, Cal ..............................

XXV. $A$, La Brea wing of the Museum of History, Science, and Art at Los Angeles, Cal.; $B$, Fossil bones in asphalt deposit of Rancho

La Brea, near Los Angeles, Cal......................

XXVI. Summerland oil field, Cal............................

XXVII. Sculptured cliffs along Coast Line near Santa Barbara, Cal.......

XXVIII. Lighthouse at Point Conception, Cal.....................

XXIX. $A$, Alluvial flat and terrace of Salinas River near Bradley, Cal; ; $B$,

Mission of San Carlos de Monterey, founded in $1770 \ldots . . . . .$.

XXX. The Pinnacles, 12 miles northeast of Soledad, Cal...............

XXXI. Big trees (Sequoia sempervirens) at Santa Cruz, Cal.............

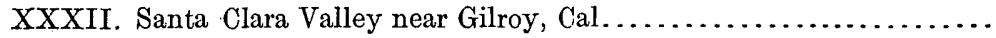

XXXIII. $A$, The arches, Stanford University, Cal.; $B$, Furrow a mile northwest of Olema, Cal., made by movement that caused the earth-

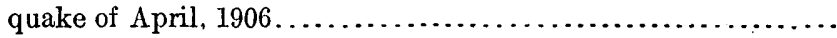

\section{FIGURES.}

Frgure 1. Map of North America showing the area covered by the Pleistocene ice sheet at its maximum extension and the three main centers of ice accumulation.

2. Generalized section of White River valley at Kent, Wash........

3. Section of bluff 2 miles north of station at Tacoma, Wash.......

4. Section of deep cut of Northern Pacific Railway across Portland Peninsula, between Vancouver, Wash., and Portland, Oreg.....

5. East-west section of Willamette Valley at Portland, Oreg.........

6. Section of east bluff at Oregon City, Oreg....................

7. Generalized section of Umpqua River valley in Coast Range, Oreg..

8. Sketch of a ginkgo leaf from the Jurassic beds of Oregon...........

9. Section of Rogue River valley near Phoenix, Oreg...............

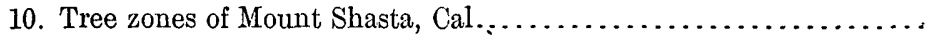

11. Section of canyon of Sacramento River just below Delta, Cal.....

12. Earthquake effects at Skinner's ranch, near Olema, Cal.........

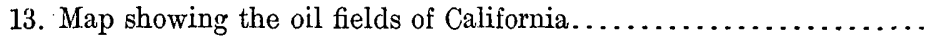

14. Generalized cross section from the Pacific Ocean to Rincon Mountain, Cal.

15. Section from Palo Alto, Cal, to the summit of the Santa Cruz Range. 


\section{INDEX OF RAILROAD STATIONS.}

A.

Ager, Cal.

Albany, Oreg.

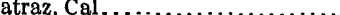

Alford, Oreg......................

Anderson, Cal....................

Anlauf, Oreg.

Antelope, Cal.

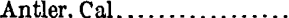

Arbuckle, Cal................

Argo, Wash.

Arguello, Cal.....................

Aromas, Cal..................... 123

Ashland, Oreg................... $\quad 57$

Atascadero, Cal.................. 118

Auburn, Wash................... 15

Aurora, Oreg................... 34

Azalea, Cal.

$B$;

Barlow, Oreg

Batavia, Cal..

Bay Shore, Cal......................

Belmont, Cal.

Ben Ali, Cal.

Benham, Cal.

Benicia Cal.

Beresford Cal .......................

Berkeley, Cal..................... 83

Biggs, Cal.......................

Black River Junction, Wash......... 14

Blunt, Cal...................... 71

Bradley, Cal..................... $\quad 119$

Bromela, Cal..................... 114

Brôks, Oreg.................... 35

Bucoda, Wash................... 20

Burbank, Cal................... 98

Burlingame, Cal................ 129

C.

Callender, Cal.................... 114

Camarillo, Cal................... 103

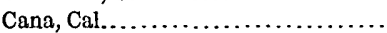

Canby, Oreg.................... 34

Cannon, Cal......................

Capitan, Cal...................... 109

Carnadero, Cal.................... 124

Carnes, Oreg .....................

Carpinteria, Cal.................. 106

Carrolls, Wash................... 24

Casmalia, Cal..................... 113

Castella, Cal..................... 64

Cast'e Crag, Cal..................... 63

Castle Rock, Wash................ 23

Central Mine, Cal.................. 68
Page. Sheet.

Central Point, Oreg................. $51 \quad 7$

Chambers Prairie, Wash............. $20 \quad 2$

Centralia, Wash.................. $21 . \quad 2$

$3 \mathrm{~A}$

Chatsworth, Cal.................... $100 \quad 1 \mathrm{~A}$

Chehalis, Wash................... $21 \quad 2$

Chemawa, Oreg.................... $35 \quad 4$

Chico, Cal....................... 10

Chittenden, Cal................. $123 \quad 6 \mathrm{~A}$

Chorro, Cal..................... $4 \mathrm{~A}$

Chualar; Cal..................... $121 \quad 5 \mathrm{~A}$

Clackamas, Oreg................. 32

Coalca, Oreg...................... 33

Coburn, Cal..................... $5 \mathrm{~A}$

Cole, Cal...................... $58 \quad 7$

Colestin, Oreg.................... $58 \quad 7$

Colusa Junction, Cal............... $75 \quad 11$

Comstock, Oreg.................. $40 \quad 5$

Concepcion, Cal................. $110 \quad 3 \mathrm{~A}$

Coram, Cal..................... $67 \quad 9$

Corning, Cal..................... $73 \quad 10$

Cosomar, Cal.................... $2 \mathrm{~A}$

Cottage Grove, Oreg................ $39 \quad 5$

Cottonwood, Cal................... $70 \quad 9$

Co:r Creek, Oreg...................

Cojote, Cal...................... $125 \quad 6 \mathrm{~A}$

Creswell, Oreg..................... 39.5

Cuesta, Cal..................... 116

D.

Davis, Cal........................ $77 \quad 12$

Del Monte Junction, Cal ............ $122 \quad 5 \mathrm{~A}$

Delavan, Cal.................... $75 \quad 10$

Delta, Cal...................... $65 \quad 9$

Dillard, Oreg.................... $43 \quad 43$

Divide, Oreg.................... $39 \quad 5$

Dixon, Cal...................... $78 \quad 12$

Doe Creek, Oreg................... 6

Dole, Oreg...................... $43 \quad 6$

Drain, Oreg.................... $41 \quad 5$

Drake, Cal...................... 3A

Dunnigan, Cal.................... $76 \quad 11$

Dunsmuir, Cal.................... $63 \quad 8$

Durham, Cal.................... 10

E.

Eaglet, Cal..................... 117

East A Iorrison Street, Oreg.......... 32

Edenvale, Cal................... 126

Edgewood, Cal.................... 61

Edna, Cal...................... 114

Ilkhom, Cal..................... 122

Elmira, Cal..................... 78

Elmore, Cal. .................... 65

Elwood, Cal.................... 109

Eugene, Ores................... 37

$4 \mathrm{~A}$

8

$4 \mathrm{~A}$

12

9

$2 A$

5

Evaline, Wash.................. 
F.

Page. Sheet.

Fairfield, Cal.

78

G.

Gato, Cal.

Gaviota, Cal

Gazelle, Cal.

Georgetown, Wash.

Gerber, Cal. .

Germantown, Cal..................

Gervais, Oreg.

Gibson, Cal..

Gilroy, Cal.

Girvan, Cal... .

(n)

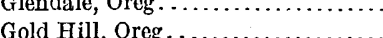

Goldtree, Cal. .

Goleta, Cal.......................

Gonzales, Cal

Goshen, Oreg.

Grants Pass, Oreg.

Green, Oreg.

Greenwood, Cal. ..................

Grenada, Cal.....................

Gridley, Cal.

Grover, Cal. .

Guadalupe, Cal.

H.

Halsey, Oreg.

Harrisburg, Oreg.

Hasson, Cal.

Hercules, Ca

Hewitt, Cal......................

Hillhurst, Wash.

Hillsdale, Cal. .

Honda, Cal. .

Hooker, Cal. ......................

Hope Ranah, Cal, .................

Hornbrook, Cal..

Hubbard, Oreg.

Hugo, Ores.

Irving, Oreg.

Ivrea, Cal..

J.

Jalama, Cal.

Jefferson . Oreg...

Junction City, Oreg.

$\mathrm{K}$.

Kalama, Wash

Kelso, Wash.

Kennett, Cal.

Kent, Wash.

Keswick, Cal.

Ketron, Wash.

King City, Cal.

Kirkwood, Cal.

Klamathon, CaJ.

Knapps, Wash.

Kyro, Wash.

$4 \mathrm{~A}$

$3 \mathrm{~A}$
L.

Page. Sheet.

Lagol, Cal. 102

Lakeview, Wash.

Lamoine, Cal. .

, Cal....................... 64

$3 \mathrm{~A}$

Latham, Oreg.

Leesdale, Cal...

$3 \mathrm{~A}$

Lento, Cal..

Leona, Oreg...................... $40 \quad 5$

Leslie, Cal..

Lincoln, Cal.....................

Liveoak, Cal.

Logandale, Cal.................. 75

$6 \mathrm{~A}$

Lompoc Junction, Cal . .

Los Angeles, Cal................... 91

Lyman, Cal................... 74

M.

McIntosh, Wash.

5A McKay, Cal .................... 119

Madrone, Cal.................. 125

Malton, Cal..................... 73

Marion, Oreg..................... 36

Martins Bluff, Wash................

Marysville, Cal.

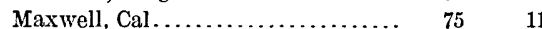

Medford, Oreg.................... $51 \quad 7$

Menlo Park, Cal................... $128 \quad 6 \mathrm{~A}$

Merlin, Oreg.................... $48 \quad 7$

Merritt, Cal...................... 12

Metz, Cal...................... 5A

Middle Creek, Cal................ $68 \quad 9$

Millbrae, Cal.................. $130 \quad 13$

1A Millersburg, Oreg................. 36

Milwaukee, Oreg................ 32

6A Miramar, Cal................... 107

3A Montague, Cal.................. 60

9 Montalvo, Cal.................... 104

Moorpark, Cal................. 102

Morley, Cal.

Motion, Cal..................... 67

Mott, Cal..................... 63

Mountain View, Cal.............. 127

Mullen, Cal..................... 12

Myrtle Creek, Oreg............... 44

N.

Nacimiento, Cal.................. $4 \mathrm{~A}$

$3 \mathrm{~A}$

Napavine, Wash................ 22

Naples, Cal.................... 109

2

$2 \mathrm{~A}$

Narlon, Cal...................... 3A

Nelson, Cal..................... 10

New Era, Oreg.................. $33 \quad 4$

Nichols, Oreg..................... $446 \quad .6$

Nisqually, Wash.................. $19 \quad 1$

Nord, Cal...................... 10

Norman, Cal.................... $75 \quad 10$

North Puyallup, Wash............ 15

o.

Oakland, Cal.

$84 \quad 13$

Oakland, Oreg................... $41 \quad 6$

$0^{\prime}$ Brien, Wash.................... 1

Oceano, Cal..................... $114 \quad 3 \mathrm{~A}$

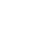

8

9

12


Page. Sheet.

Olequa, Wash.................. 23

Oregon City, Oreg................ 32

Orella, Cal...................... 109

Orland, Cal......................... 73

Ostrander, Wash ................. 23

Oxnard, Cal...................... 103

P.

Palo Alto, Cal.................. 127

Paso Robles, Cal................. 118

Phoenix, Oreg................... 56

Pinole, Cal..................... \$2

Pismo, Cal.................... 114

Pitt, Cal......................... 66

Plumb, Wash................... 20

Port Costa, Cal................... $\quad 79$

Portland, Oreg................... $\quad 30$

Proberta, Cal.................... 72

R.

Rainier, Wash.

Rawson, Cal......................

Raymer, Cal......................

Red Bluff, Cal...................

Redding, Cal.....................

Redwood, Cal.....................

Reuben, Oreg....................

Rice Hill, Oreg....................

Richfield, Cal...

( Cal.

Richvale, $\mathrm{Ca}$ !

Ridgefield, Wash.................

Rodeo, Cal.

Rogue River, Oreg ..................

Roseburg, Oreg....................

Roseville, Cal....................

Round Prairie, Orog................

Roy, Wash.

S.

Sacate, Cal

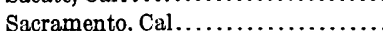

Safety, Oreg..

Saginaw, Oreg.

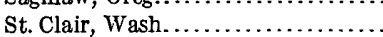

Salem, Oreg.......................

Salinas, Cal.........................

San Ardo, Cal.................. 120

San Bruno, Cal................. 130

San Carlos, Cal.................. 128

San Francisco, Cal............... $\quad 86$

San Jose, Cal..................... 126

San Lucas, Cal. ................... 120

San Luis Obispo, Cal.............. 115

San Martin, Cal.

San Mateo, Cal.................. $\quad 129$

San Miguel, Cal................. 118

San Pablo, Cal................... 82

Santa Barbara, Cal.............. 108

Santa Clara, Cal.................. 126

Santa Cruz, Cal.................... 123

Santa Margarita, Cal............. 116

Santa Susana, Cal. ............... 100

Sargent, Cal.................... 124

Schumann, Cal.
Seacliff, Cal Page. Shoet.

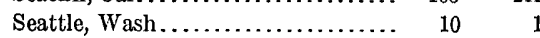

Serrano, Cal..................... $116 \quad 4 \mathrm{~A}$

Shasta Springs, Cal.................. $63 \quad 8$

Shedd, Oreg...................... $37 \quad 5$

2A Sheridan, Cal.................... 11

Simi, Cal........................ $102 \quad 1 \Lambda$

Sims, Cal....................... 64.8

Siskiyou, Oreg..................... $58 \quad 7$

Sisson, Cal........................ $62 \quad 8$

Smithson, Cal.................... $65 \quad 9$

Snowdon, Cal...................... $60 \quad 8$

Soledad, Cal.................... $121 \quad 5 \Lambda$

Somis, Cal....................... $103 \quad 2 A$

Soto, Cal....................... 10

South San Francisco, Cal.......... $131 \quad 13$

South Tacoma, Wash...............

South Winlock, Wash..............

Springfield Junction, Oreg........... $38 \quad 5$

Steilacoom, Wash.................. $18 \quad 1$

Steinman, Oreg................... $58 \quad 7$

Strathearn, Cal.................. $1 \mathrm{~A}$

Sudden, Cal...................... $110 \quad 3 A$

Suisun, Cal...................... $78 \quad 12$

Summerland, Cal................ $107 \quad 2 \mathrm{~A}$

Summit, Cal..................... $61 \quad 8$

Sumner, Wash................... $15 \quad 1$

Sunnyvale, Cal................. $127 \quad 6 \mathrm{~A}$

Surf, Cal.......................

Sutherlin, Oreg................. $41 \quad 6$

$\mathrm{T}$.

Tacoma, Wash................... $16 \quad 1$

Tajiguas, Cal................... $109 \quad 3 \mathrm{~A}$

Talent, Oreg.................... $56 \quad 7$

Tangair, Cal.................... $112 \quad 3 \mathrm{~A}$

Tangent, Oreg.................... $37 \quad 4$

Tehama, Cal..................... $72 \quad 10$

Templeton, Cal.................. $118 \quad 4 \mathrm{~A}$

Tenino, Wash................... $20 \quad 2$

Ternez, Cal..................... 102

Thrall, Cal..................... 60

Tolo, Oreg..................... 51

Tropico, Cal................... 97

Turner, Oreg.................... 36

Tyler, Cal...

V.

Vader, Wash .................... 22

Vallejo Junction, Cal.............. so

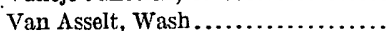

Vancouver, wash................ 25

Vancouver Junction, Wash.......... $\quad 25$

Ventura, Cal..................... 104

Vina, Cal....................... 10

Visitacion, Cal.................... 13

W.

Wabash, Wash

Waldorf, Cal.................... $3 A$

Walker, Oreg.................... $39 \quad 5$

Washington, Cal.................. 12

Watsonville Junction, Cal.......... $123 \quad 6 \mathrm{~A}$

Weed, Cal........................ $61 \quad 8$

Wellsona, Cal.................... $4 \mathrm{~A}$

West Fork, Oreg.................. $46 \quad 6$ 
Page. Sheet.

West Glendale, $\mathrm{Cal}$

Wheatland, Cal..................

Wilbur, Oreg..

Willbridge, Oreg.................

Williams, Cal

Willows, Cal..................... 74

Willsburg, Oreg.................

Winchester, Oreg.................. 42

Winlock, Wash................... 22

Wolf Creek, Oreg................ 47

Woodburn, Oreg.................. 34

woodland, Cal................. 77

98
42
75
74

42
22
47
34
77

Woodland, Wash.......

Wunpost, Cal...

11

3

11

10

3

2

7

12
Page. Shoet.

24

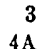

$\mathbf{Y}$.

Yelm, Wash............

Yolo, Cal..................... $76 \quad 11$

Yoncalla, Oreg.................. $41 \quad 6$

Z.

Zamora, Cal................... $76 \quad 11$

Zelzah, Cal................... $99 \quad 1 \mathrm{~A}$

Zuleka, Cal.................... . 7 